Prepared in cooperation with the U.S. Department of Energy

\title{
Evaluation of Chemical and Hydrologic Processes in the Eastern Snake River Plain Aquifer Based on Results from Geochemical Modeling, Idaho National Laboratory, Eastern Idaho
}

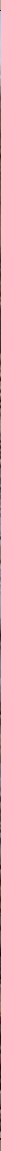

Professional Paper 1837-B

U.S. Department of the Interior

U.S. Geological Survey 
Cover: Photograph showing leading edge of the Big Lost River, eastern Idaho. Photograph by U.S. Geological Survey, March 2017. 


\section{Evaluation of Chemical and Hydrologic Processes in the Eastern Snake River Plain Aquifer Based on Results from Geochemical Modeling, Idaho National Laboratory, Eastern Idaho}

By Gordon W. Rattray

DOE/ID-22248

Prepared in cooperation with the U.S. Department of Energy

Professional Paper 1837-B 


\title{
U.S. Department of the Interior DAVID BERNHARDT, Secretary
}

\author{
U.S. Geological Survey \\ James F. Reilly II, Director
}

\section{U.S. Geological Survey, Reston, Virginia: 2019}

For more information on the USGS - the Federal source for science about the Earth, its natural and living resources, natural hazards, and the environment-visit https://www.usgs.gov or call 1-888-ASK-USGS.

For an overview of USGS information products, including maps, imagery, and publications, visit https://store.usgs.gov/.

Any use of trade, firm, or product names is for descriptive purposes only and does not imply endorsement by the U.S. Government.

Although this information product, for the most part, is in the public domain, it also may contain copyrighted materials as noted in the text. Permission to reproduce copyrighted items must be secured from the copyright owner.

Suggested citation:

Rattray, G.W., 2019, Evaluation of chemical and hydrologic processes in the eastern Snake River Plain aquifer based on results from geochemical modeling, Idaho National Laboratory, eastern Idaho: U.S. Geological Survey Professional Paper 1837-B (D0E/ID-22248), 85 p., https://doi.org/10.3133/pp1837B.

\section{Library of Congress Cataloging-in-Publication Data}

Names: Rattray, Gordon W., author. | Geological Survey (U.S.), issuing body. | United States. Department of Energy.

Title: Evaluation of chemical and hydrologic processes in the eastern Snake

River Plain Aquifer based on results from geochemical modeling, Idaho

National Laboratory, eastern Idaho / by Gordon W. Rattray.

Other titles: Professional paper (Geological Survey (U.S.)) ; 1837-B.

Description: Reston, Virginia : U.S. Department of the Interior, U.S.

Geological Survey, 2019. | Series: Professional paper; 1837-B |

"DOE/ID-22248." | Includes bibliographical references. |

Identifiers: LCCN 2019035329 | ISBN 9781411343252 (paperback)

Subjects: LCSH: Idaho National Laboratory. | Geochemical modeling--Idaho--Snake River Plain Aquifer. | Water--Pollution--Idaho--Snake River Plain Aquifer. | Water quality--Idaho--Snake River Plain Aquifer. | Groundwater recharge--Idaho. | Radiochemical laboratories--Waste disposal--Idaho. Classification: LCC 0E515.5.G43 R39 2019 | DDC 551.90979653--dc23 | SUDOC I 19.16:1837-B

LC record available at https://lccn.loc.gov/2019035329 


\section{Contents}

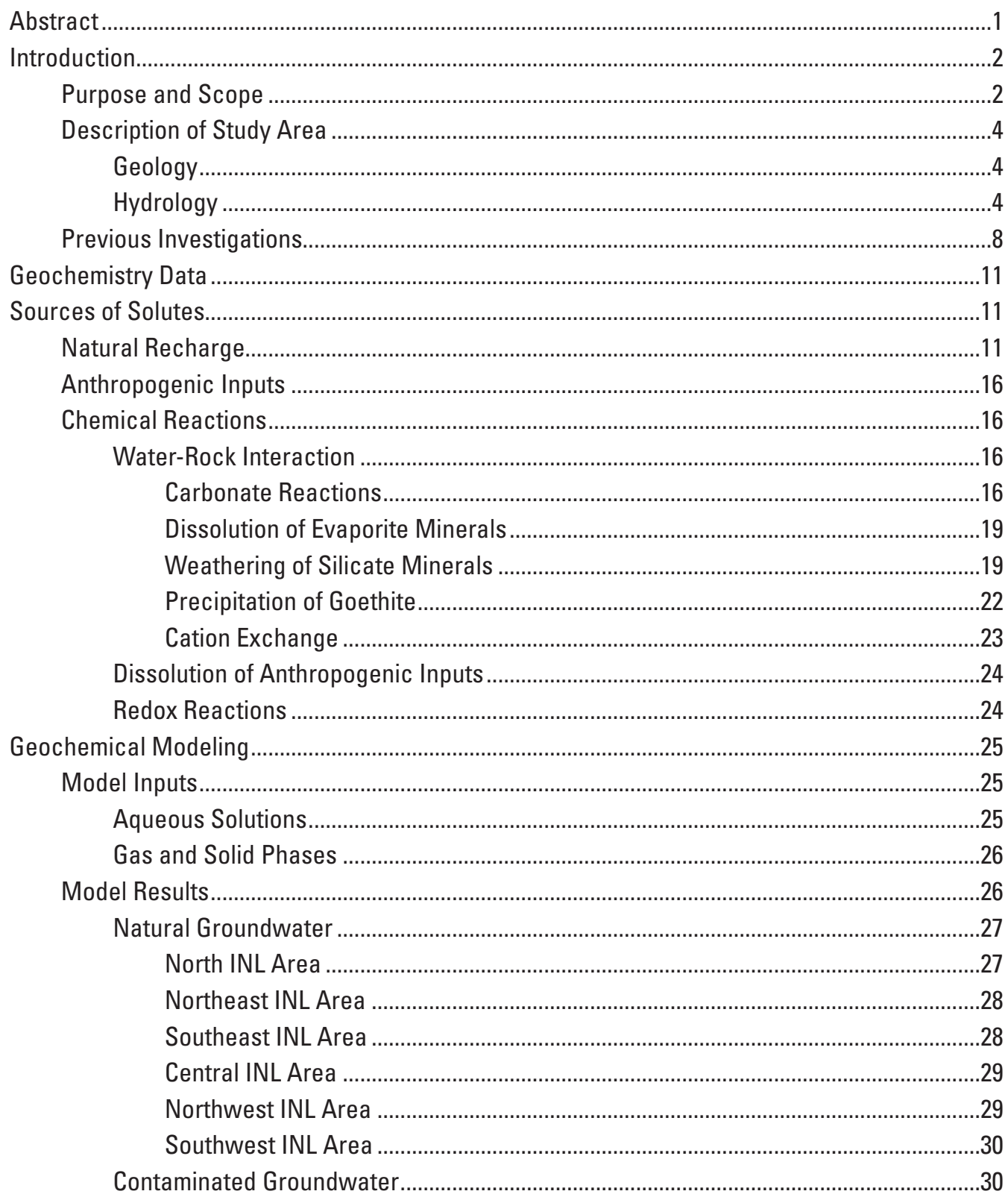




\section{Contents-Continued}

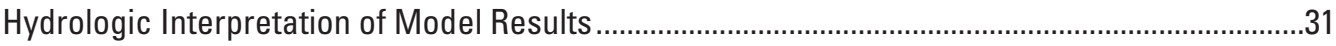

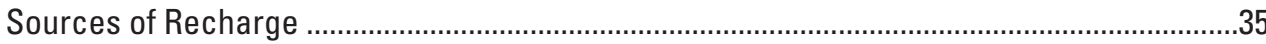

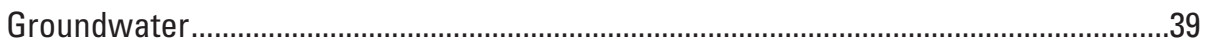

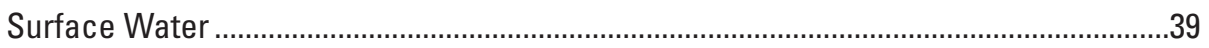

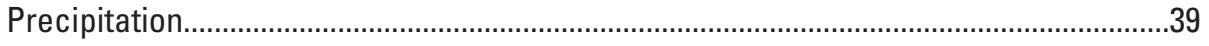

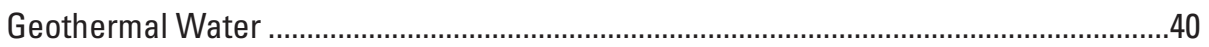

Comparison with Other Studies that Estimated Sources of Recharge ............................40

Comparison with Chapter A (Rattray, 2018) ..............................................................40

Comparison with Groundwater Flow Model ..............................................................44

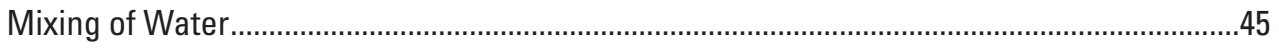

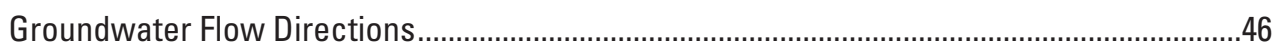

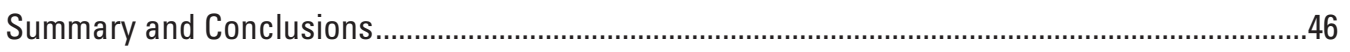

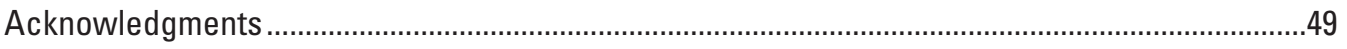

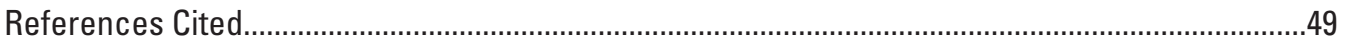

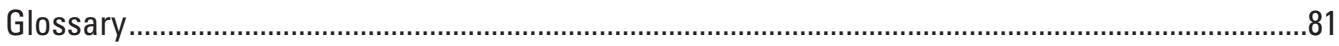

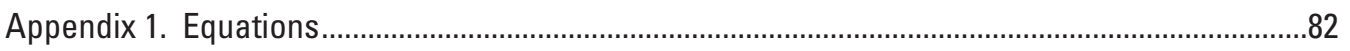

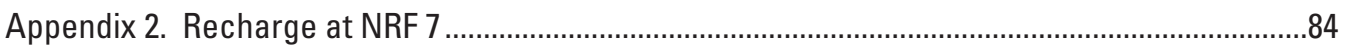




\section{Figures}

1. Map showing geographic features and generalized land cover and land use for surrounding mountain ranges, Idaho National Laboratory (INL) and vicinity, eastern Idaho.

2. Map showing land cover and irrigation, Idaho National Laboratory and vicinity, eastern Idaho

3. Map showing surface geology and structural features, Idaho National Laboratory and vicinity, eastern Idaho

4. Graph showing mean annual discharge of the Big Lost River below INL diversion near Arco and INL diversion at head near Arco, Idaho National Laboratory, eastern Idaho.....

5. Map showing locations of wells with water-level measurements and 1989 water-table contours, Idaho National Laboratory and vicinity, eastern Idaho

6. Map showing areas and flow paths where geochemical mass-balance models of groundwater were previously done, at and adjacent to the Idaho National Laboratory, eastern Idaho

7. Map showing locations of water-quality sample collection sites, Idaho National Laboratory and vicinity, eastern Idaho.

8. Map showing hydrochemical facies of surface water and groundwater, Idaho National Laboratory and vicinity, eastern Idaho

9. Map showing saturation indices for calcite for surface water and groundwater, Idaho National Laboratory and vicinity, eastern Idaho.

10. Graph showing silica concentrations and saturation indices for amorphous silica for surface water and groundwater, Idaho National Laboratory and vicinity, eastern Idaho.

11. Map showing saturation indices for amorphous silica for surface water and groundwater, Idaho National Laboratory and vicinity, eastern Idaho

12. Diagram showing stability relations between kaolinite and calcium montmorillonite with superposed compositions of water samples, Idaho National Laboratory and vicinity, eastern Idaho.

13. Diagram showing stability relations between calcium beidellite and sodium beidellite with superposed compositions of water samples, Idaho National Laboratory and vicinity, eastern Idaho.

14. Maps showing areas indicating percentage of wastewater discharged from selected site facilities, Idaho National Laboratory and vicinity, eastern Idaho

15. Maps showing sources of recharge based on geochemical modeling, Idaho National Laboratory and vicinity, eastern Idaho

16. Maps showing sources of recharge, Idaho National Laboratory and vicinity, eastern Idaho

17. Map showing mixing lines and zone of mixing between regional groundwater and tributary valley water, Idaho National Laboratory and vicinity, eastern Idaho

18. Map showing water-table contours for 1989 and approximate groundwater-flow directions based on groundwater sources of recharge and mixing lines, Idaho National Laboratory and vicinity, eastern Idaho 


\section{Tables}

1. Site names and numbers and abbreviated name for water-quality sample sites, Idaho National Laboratory and vicinity, eastern Idaho.

2. Chemical reactions that may act as sources or sinks of gases and solutes to or from groundwater, Idaho National Laboratory and vicinity, eastern Idaho.

3. Mean annual concentration of chloride in wastewater discharged at Idaho Nuclear Technology and Engineering Center, Naval Reactors Facility, and Central Facilities Area, Idaho National Laboratory and vicinity, eastern Idaho.

4. Percentage of wastewater discharged from the Naval Reactors Facility industrial waste ditch or the Idaho Nuclear Technology and Engineering Center infiltration ponds in groundwater at downgradient sites, 1995-96 groundwater chemistry conditions, Idaho National Laboratory and vicinity, eastern Idaho

5. Sources of recharge from model results at wells NPR W01 and NPR Test, Idaho National Laboratory, eastern Idaho.

6. Measurements of field parameters, calculated partial pressure of carbon dioxide, and concentrations of aluminum and iron, Idaho National Laboratory and vicinity, eastern Idaho

7. Concentrations of major ions, silica, and the charge balance for water-quality analyses from precipitation, surface water, and groundwater, Idaho National Laboratory and vicinity, eastern Idaho.

8. Measurements of the stable isotope ratios of hydrogen, oxygen, and carbon and the activity of tritium, Idaho National Laboratory and vicinity, eastern Idaho

9. Mineral/water thermodynamic saturation indices for selected minerals with respect to chemical compositions for precipitation, surface water, and groundwater, Idaho National Laboratory and vicinity, eastern Idaho

10. Representative geochemical mass-balance modeling results, Idaho National Laboratory and vicinity, eastern Idaho.

11. Sources of recharge for groundwater based on geochemical modeling at and south of the Idaho National Laboratory, eastern Idaho 


\section{Conversion Factors}

U.S. customary units to International System of Units

\begin{tabular}{|c|c|c|}
\hline Multiply & By & To obtain \\
\hline \multicolumn{3}{|c|}{ Length } \\
\hline inch (in.) & 2.54 & centimeter $(\mathrm{cm})$ \\
\hline foot $(\mathrm{ft})$ & 0.3048 & meter $(\mathrm{m})$ \\
\hline mile (mi) & 1.609 & kilometer (km) \\
\hline \multicolumn{3}{|c|}{ Area } \\
\hline acre & 0.4047 & hectare (ha) \\
\hline square mile $\left(\mathrm{mi}^{2}\right)$ & 2.590 & square kilometer $(\mathrm{km} 2)$ \\
\hline \multicolumn{3}{|c|}{ Volume } \\
\hline gallon per minute (gal/min) & 3.785 & liter per minute (L/min) \\
\hline \multicolumn{3}{|c|}{ Flow rate } \\
\hline cubic foot per second $\left(\mathrm{ft}^{3} / \mathrm{s}\right)$ & 0.02832 & cubic meter per second $\left(\mathrm{m}^{3} / \mathrm{s}\right)$ \\
\hline \multicolumn{3}{|l|}{ Radioactivity } \\
\hline picocurie per liter $(\mathrm{pCi} / \mathrm{L})$ & 0.037 & becquerel per liter $(\mathrm{Bq} / \mathrm{L})$ \\
\hline \multicolumn{3}{|c|}{ Hydraulic conductivity } \\
\hline foot per day (ft/d) & 0.3048 & meter per day $(\mathrm{m} / \mathrm{d})$ \\
\hline
\end{tabular}

International System of Units to U.S. customary units

\begin{tabular}{lll}
\hline \multicolumn{1}{c}{ Multiply } & \multicolumn{1}{c}{ By } & \multicolumn{1}{c}{ To obtain } \\
\hline \multicolumn{2}{c}{ Volume } \\
\hline cubic meter $\left(\mathrm{m}^{3}\right)$ & 6.290 & barrel (petroleum, 1 barrel = 42 gal) \\
liter $(\mathrm{L})$ & 0.2642 & gallon (gal) \\
\hline \multicolumn{2}{c}{ Mass } \\
\hline gram $(\mathrm{g})$ & 0.03527 & ounce, avoirdupois $(\mathrm{oz})$ \\
kilogram $(\mathrm{kg})$ & 2.205 & pound avoirdupois $(\mathrm{lb})$ \\
\hline
\end{tabular}

Temperature in degrees Celsius $\left({ }^{\circ} \mathrm{C}\right)$ may be converted to degrees Fahrenheit $\left({ }^{\circ} \mathrm{F}\right)$ as follows:

$$
{ }^{\circ} \mathrm{F}=\left(1.8 \times{ }^{\circ} \mathrm{C}\right)+32 .
$$

\section{Datums}

Vertical coordinate information is referenced to the National Geodetic Vertical Datum of 1929 (NGVD 29).

Horizontal coordinate information is referenced to the North American Datum of 1927 (NAD 27). Altitude, as used in this report, refers to distance above the vertical datum. 


\title{
Supplemental Information
}

Specific conductance is given in microsiemens per centimeter at 25 degrees Celsius $\left(\mu \mathrm{S} / \mathrm{cm}\right.$ at $\left.25^{\circ} \mathrm{C}\right)$.

Concentrations of chemical constituents in water are given in either milligrams per liter $(\mathrm{mg} / \mathrm{L})$ or micrograms per liter $(\mu \mathrm{g} / \mathrm{L})$.

Phase mole transfer amounts are given in micromoles per kilogram of water ( $\mu \mathrm{mol} / \mathrm{kg}$ water).

Activities for radioactive constituents in water are given in picocuries per liter (pCi/L).

\section{Abbreviations}

\author{
ATRC Advanced Test Reactor Complex \\ AVH axial volcanic highland \\ BC Birch Creek \\ BLR Big Lost River \\ $\mathrm{CB}$ charge balance \\ CEC cation exchange capacity \\ CFA Central Facilities Area \\ DOE U.S. Department of Energy \\ ESRP eastern Snake River Plain \\ IAP ion activity product \\ INL Idaho National Laboratory \\ INEEL Idaho National Engineering and Environmental Laboratory \\ INTEC Idaho Nuclear Technology and Engineering Center \\ $\mathrm{K} \quad$ hydraulic conductivity \\ LLR Little Lost River \\ MFC Materials and Fuels Complex \\ NRF Naval Reactors Facility \\ NWIS U.S. Geological Survey National Water Information System \\ RWMC Radioactive Waste Management Complex \\ SI saturation index \\ TAN Test Area North \\ USGS U.S. Geological Survey
}




\title{
Evaluation of Chemical and Hydrologic Processes in the Eastern Snake River Plain Aquifer Based on Results from Geochemical Modeling, Idaho National Laboratory, Eastern Idaho
}

\author{
By Gordon W. Rattray
}

\begin{abstract}
Nuclear research activities at the U.S. Department of Energy (DOE) Idaho National Laboratory (INL) produced liquid and solid chemical and radiochemical wastes that were disposed to the subsurface resulting in detectable concentrations of some waste constituents in the eastern Snake River Plain (ESRP) aquifer. These waste constituents may affect the water quality of the aquifer and may pose risks to the eventual users of the aquifer water. To understand these risks to water quality the U.S. Geological Survey, in cooperation with the DOE, conducted geochemical mass-balance modeling of the ESRP aquifer to improve the understanding of chemical reactions, sources of recharge, mixing of water, and groundwater flow directions in the shallow (upper 250 feet) aquifer at the INL.

Modeling was conducted using the water chemistry of 127 water samples collected from sites at and near the
\end{abstract} INL. Water samples were collected between 1952 and 2017 with most of the samples collected during the mid-1990s. Geochemistry and isotopic data used in geochemical modeling consisted of dissolved oxygen, carbon dioxide, major ions, silica, aluminum, iron, and the stable isotope ratios of hydrogen, oxygen, and carbon.

Geochemical modeling results indicated that the primary chemical reactions in the aquifer were precipitation of calcite and dissolution of plagioclase $\left(\mathrm{An}_{60}\right)$ and basalt volcanic glass. Secondary minerals other than calcite included calcium montmorillonite and goethite. Reverse cation exchange, consisting of sodium exchanging for calcium on clay minerals, occurred near site facilities where large amounts of sodium were released to the ESRP aquifer in wastewater discharge. Reverse cation exchange acted to retard the movement of wastewater-derived sodium in the aquifer.

Regional groundwater inflow was the primary source of recharge to the aquifer underlying the Northeast and Southeast INL Areas. Birch Creek (BC), the Big Lost River (BLR), and groundwater from $\mathrm{BC}$ valley provided recharge to the North INL Area, and the BLR and groundwater from BC and Little
Lost River (LLR) valleys provided recharge to the Central INL Area. The BLR, groundwater from the BLR and LLR valleys and the Lost River Range, and precipitation provided recharge to the Northwest and Southwest INL Areas. The primary source of recharge west and southwest of the INL was groundwater inflow from BLR valley. Upwelling geothermal water was a small source of recharge at two wells. Aquifer recharge from surface water in the northern, central, and western parts of the INL indicated that the aquifer in these areas was a dynamic, open system, whereas the aquifer in the eastern part of the INL, which receives little recharge from surface water, was a relatively static and closed system.

Sources of recharge identified from isotope ratios and geochemical modeling (major ion concentrations) were nearly identical for the North, Northeast, Southeast, and Central INL Areas, which indicated that both methods probably accurately identified the sources of recharge in these areas. Conversely, isotope ratios indicated that the BLR and groundwater from the LLR valley provided most recharge to the western parts of the Northwest and Southwest INL Areas, whereas geochemical modeling results indicated a smaller area of recharge from the BLR and groundwater from the LLR valley, a larger area of recharge from the Lost River Range, and recharge of groundwater from the BLR valley that extended to the west INL boundary. The results from geochemical modeling probably were more accurate because major ion concentrations, but not isotope ratios, were available to characterize groundwater from the BLR valley and the Lost River Range.

Sources of recharge identified with a groundwater flow model (using particle tracking) and geochemical modeling were similar for the Northeast and Southeast INL Areas. However, differences between the models were that the geochemical model represented (1) recharge of groundwater from the Lost River Range in the western part of the INL, whereas the flow model did not, (2) recharge of groundwater from the BC and BLR valleys extending farther south and east, respectively, than the flow model, and (3) more recharge from the BLR in the Southwest INL Area than the flow model. 
Mixing of aquifer water beneath the INL included (1) mixing of regional groundwater and water from the $\mathrm{BC}$ valley in the Northeast and Southeast INL Areas and (2) mixing of surface water (primarily from the BLR) and groundwater across much of the North, Central, Northwest, and Southwest INL Areas. Localized recharge from precipitation mixed with groundwater in the Northwest and Southwest INL Areas, and localized upwelling geothermal water mixed with groundwater in the Central and Northeast INL Areas. Flow directions of regional groundwater were south in the eastern part of the INL and south-southwest at downgradient locations. Groundwater from the BC and LLR valleys initially flowed southeast before changing to south-southwest flow directions that paralleled regional groundwater, and groundwater from the BLR valley initially flowed south before changing to a southsouthwest direction.

Wastewater-contaminated groundwater flowed south from the Idaho Nuclear Technology and Engineering Center (INTEC) infiltration ponds in a narrow plume, with the percentage of wastewater in groundwater decreasing due to dilution, dispersion, and (or) degradation from about 60-80 percent wastewater $0.7-0.8$ mile (mi) south of the INTEC infiltration ponds to about 1.4 percent wastewater about $15.5 \mathrm{mi}$ south of the INTEC infiltration ponds. Wastewatercontaminated groundwater flowed southeast and then southwest from the Naval Reactors Facility industrial waste ditch, with the percentage of wastewater in groundwater decreasing from about 100 percent wastewater adjacent to the waste ditch to about 2 percent wastewater about $0.6 \mathrm{mi}$ south of the waste ditch.

\section{Introduction}

The eastern Snake River Plain (ESRP) aquifer is an important resource for the State of Idaho because it supplies water for industry, irrigation for approximately 900,000 acres of farmland, and is the sole source of drinking water for approximately 200,000 people (Idaho Department of Environmental Quality, 2015). Nuclear research activities at the Idaho National Laboratory (INL), a U.S. Department of Energy (DOE) site established on the ESRP in eastern Idaho in 1949, produced liquid and solid chemical and radiochemical wastes that were disposed to the subsurface at various INL facilities (fig. 1). The disposal of these wastes resulted in detectable concentrations of some waste constituents in the ESRP aquifer (Davis and others, 2013).

The presence of chemical and radiochemical wastes in the ESRP aquifer may affect the water quality of the aquifer, which could pose risks to the users of the aquifer. These risks are a concern of the State of Idaho, DOE, and the public. To understand how contaminants may affect water quality, the U.S. Geological Survey (USGS), in cooperation with the DOE, is doing geochemistry studies to improve the understanding of chemical and hydrologic processes in the
ESRP aquifer at and near the INL and to determine how these processes affect waste constituents in the aquifer. Additionally, results from the geochemistry studies will be used to constrain and (or) calibrate groundwater-flow models of the ESRP aquifer at the INL (Fisher and others, 2012).

In Chapter A of Professional Paper 1837 (Rattray, 2018), descriptions of hydrologic processes (sources of water, mixing of water, and groundwater flow directions) in the shallow ESRP aquifer at the INL were based on evaluation of the geochemistry of surface water and groundwater at and near the INL. This report (Chapter B) describes geochemical mass-balance modeling conducted to investigate these same hydrologic processes as well as the chemical processes controlling the chemistry of shallow groundwater in the ESRP aquifer at the INL. Although the objectives of these two studies were similar, the two studies achieved these objectives through independent methods and complement each other. The principal geochemical data used to identify hydrologic processes were strontium and uranium isotope ratios in Chapter A and major ion concentrations and hydrogen and oxygen isotope ratios in Chapter B. Strontium and uranium isotope ratios in water at the INL reflect the ratios in water from source areas, are minimally affected by water-rock interactions taking place in the ESRP aquifer, and provide a relatively straightforward method for identifying sources of recharge. Major ion concentrations and hydrogen and oxygen isotope ratios in water at the INL, in contrast, are significantly affected by physical processes and (or) water-rock interactions taking place in the aquifer. Consequently, a simple binary mixing model with strontium and uranium isotope ratios was sufficient for interpreting sources of recharge, mixing of water, and groundwater flow directions, whereas a complex geochemical model that represented water-rock interaction and mixing of water was required to evaluate the same hydrologic processes from major ion concentrations and hydrogen and oxygen isotope ratios.

\section{Purpose and Scope}

The objectives of this report were to evaluate the chemical (chemical reactions) and hydrologic (sources of recharge, mixing of water, and groundwater flow directions) processes in the shallow (upper 250 feet [ft]) ESRP aquifer at the INL with geochemical mass-balance modeling. Modeling consisted of accounting for changes in water chemistry taking place in the aquifer through (1) removal or addition of solutes to the aquifer through water-rock interactions and (2) mixing of potential source waters. Water-rock interaction was restricted to geologically-, thermodynamically-, and kinetically-plausible chemical reactions between the gaseous, aqueous, and solid phases in the groundwater system. Modeling was performed using the inverse modeling capability of the computer code PHREEQC (Parkhurst and Appelo, 2013) and the water chemistry from water samples collected at 127 sites at and near the INL. Plausible 


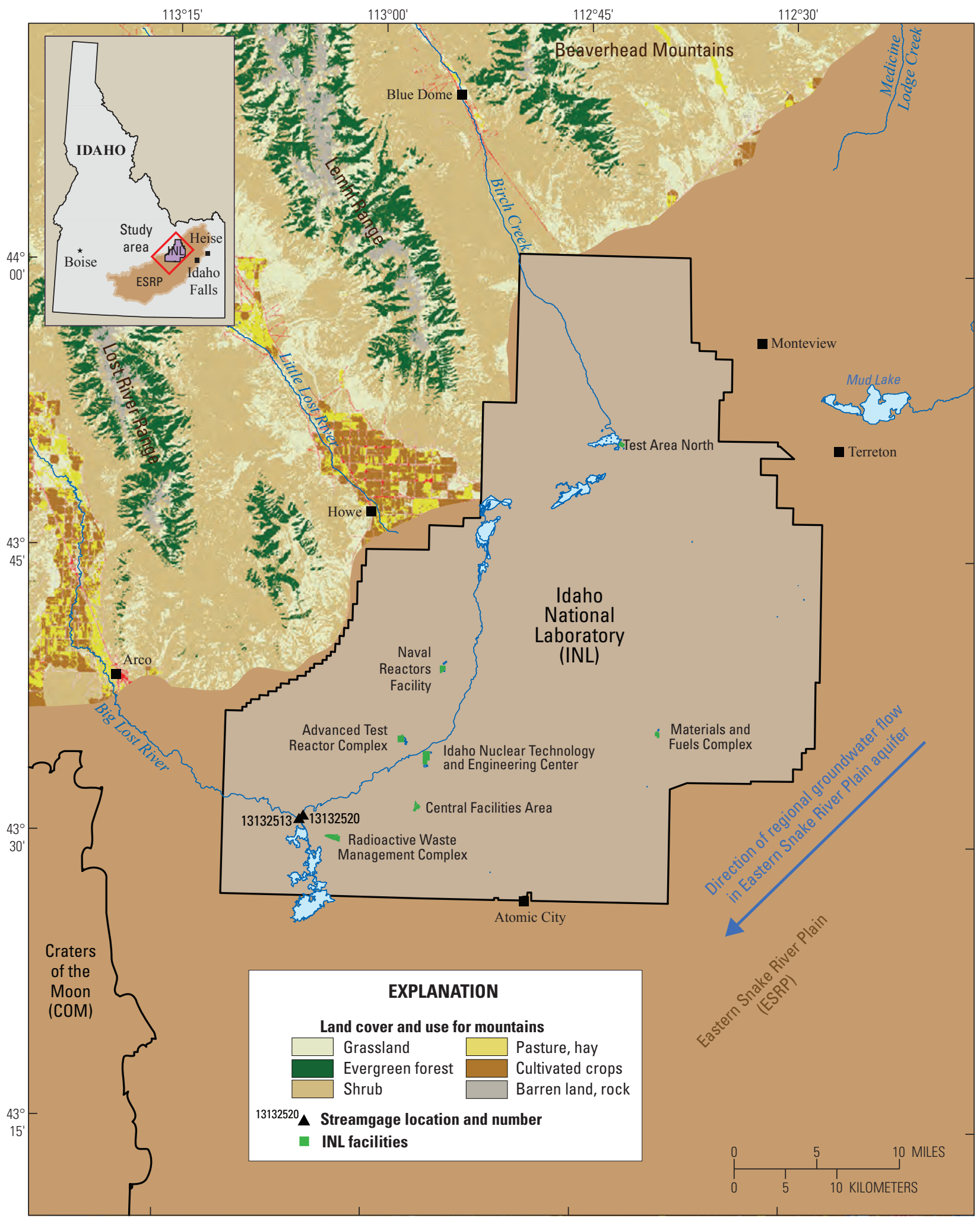

Base from U.S. Geological Survey digital data, 1:24,000 and 1:100,000.

Coordinate system and datum: NAD 27 UTM Zone 12N.

Figure 1. Geographic features and generalized land cover and land use for surrounding mountain ranges, Idaho National Laboratory (INL) and vicinity, eastern Idaho. 
groundwater flow paths between sites were determined from water-table contours and hydrologic interpretations in Professional Paper 1837-A (Rattray, 2018).

Water samples were collected between 1952 and 2017 with most of the samples collected during the mid-1990s. Chemistry and isotopic data used in geochemical modeling consisted of field parameters (water temperature and $\mathrm{pH}$ ), dissolved gases (dissolved oxygen $\left[\mathrm{O}_{2}\right]$ and carbon dioxide $\left[\mathrm{CO}_{2}\right]$ ), major ions (calcium $[\mathrm{Ca}]$, magnesium $[\mathrm{Mg}]$, sodium $[\mathrm{Na}]$, potassium $[\mathrm{K}]$, bicarbonate $\left[\mathrm{HCO}_{3}\right]$, chloride $[\mathrm{Cl}]$, sulfate $\left[\mathrm{SO}_{4}\right]$, fluoride $[\mathrm{F}]$, and nitrate $\left[\mathrm{NO}_{3}\right]$ ), silica $\left[\mathrm{SiO}_{2}\right]$, dissolved or total metals (aluminum [Al] and iron [Fe]), and stable isotopes (hydrogen-2/hydrogen-1 $\left[\delta^{2} \mathrm{H}\right],{ }^{1}$ oxygen-18/ oxygen-16 $\left[\delta^{18} \mathrm{O}\right]$, and carbon-13/carbon-12 $\left.\left[\delta^{13} \mathrm{C}\right]\right)$. Tritium activities provided a qualitative age of water (Rattray, 2018).

\section{Description of Study Area}

The study area encompasses approximately 2,000 square miles $\left(\mathrm{mi}^{2}\right)$ of eastern Idaho and includes the southern part of the Birch Creek (BC) valley and the ESRP at and south of the INL (fig. 1). The ESRP is a relatively flat topographic depression with elevations at the INL ranging from about 4,800 to 5,300 feet $(\mathrm{ft})$. The climate is semi-arid with mean annual temperature and mean annual precipitation of $42.3^{\circ} \mathrm{F}$ and 8.4 inches (in.) at the INL (period of record 1950 to 2014, National Oceanic and Atmospheric Administration, 2015). Land cover (fig. 2) in the study area includes bare rock, forest, shrub, grassland, pasture, cultivated crops, and developed areas that include industrial facilities at the INL with waste disposal areas (that is, wastewater infiltration or evaporation ponds, wastewater ditches, and waste burial sites; Davis and others, 2013). Land dominated by irrigated agriculture is present east and northwest of the study area.

\section{Geology}

The ESRP at and near the INL consists of a thick (at least 8,000 ft thick at test hole INEL-1; Mann, 1986) accumulation of Tertiary tuffs and rhyolites overlain by a thick (about 2,150 ft thick at test hole INEL-1; Mann, 1986) sequence of numerous subhorizontal Quaternary and Tertiary basalt flows (Ackerman and others, 2006) plus Quaternary and Tertiary surficial and interbed sediments (fig. 3; Doherty and others, 1979; Anderson and Liszewski, 1997). Structural features in the ESRP (fig. 3) include (1) the Axial Volcanic Highland (AVH), a broad linear topographic highland trending southwest-to-northeast formed from the accumulation of lava flows from basaltic volcanoes centered along the AVH and uplift associated with emplacement of rhyolite domes (Kuntz and others, 1992); (2) volcanic rift zones, which are broad belts of focused volcanism that generally trend northwestward and are perpendicular to the AVH and the

\footnotetext{
${ }^{1}$ The delta $(\delta)$ notation for isotope ratios is described in appendix 1.
}

direction of regional groundwater flow (figs. 1 and 3) (Kuntz and others, 1992); (3) vent corridors, which are narrow zones in and near volcanic rift zones that contain known or inferred volcanic vents, dikes, and fissures (Anderson and others, 1999); (4) caldera boundaries and (potentially) buried faults (Ginsbach, 2013); and (5) the Big Lost Trough and Mud Lake subbasins (fig. 3), long-lived sedimentary basins that were part of Pleistocene Lake Terreton (Gianniny and others, 2002).

The minerals in the aquifer matrix are the minerals in the basalt, rhyolite, and sediment that compose the aquifer and any secondary minerals, such as calcite, silica (crystalline, cryptocrystalline, or amorphous), clay, and opaques that are present in the aquifer (Knobel and others, 1997). Basalt and rhyolite are comprised of phenocrysts, a fine-grained matrix, and volcanic glass. Common minerals in basalt, in typical order of abundance, are plagioclase $\left(\mathrm{An}_{50-70}\right)$, pyroxene (augite to ferroaugite), olivine $\left(\mathrm{Fo}_{80-90}\right)$, and iron oxides (Kuntz and others, 1992; Knobel and others, 1997), and common minerals in rhyolite, in typical order of abundance, are plagioclase $\left(\mathrm{An}_{10-45}\right)$, quartz, potassium feldspar, pyroxene (augite), opaque oxides, and zircon (Morgan and others, 1984; Morgan and McIntosh, 2005).

Sediment was derived from alluvial, fluvial, lacustrine, and eolian processes. The most abundant minerals analyzed in sediment were quartz, clays, and plagioclase, with calcite and pyroxene present in lesser amounts and dolomite, olivine, and hematite present in small amounts in some sediment samples (Rightmire and Lewis, 1987; Bartholomay and others, 1989; Bartholomay, 1990; Reed and Bartholomay, 1994). The most abundant clay minerals measured from sedimentary interbeds at the INL were smectites, ${ }^{2}$ illite, and kaolinite (Rightmire and Lewis, 1987; Reed and Bartholomay, 1994), with illite generally considered to be of detrital origin (Rightmire, 1984). Gypsum (or anhydrite) was present in evaporite deposits associated with lacustrine sediment in the northern and south-central parts of the INL (Blair, 2002; Geslin and others, 2002), may be present in the northern part of the INL in alluvial and fluvial sediment from the BC valley and Beaverhead Mountains (Robertson and others, 1974), and may be present throughout the INL in eolian sediment (Wood and Low, 1988).

\section{Hydrology}

Hydrologic features in the study area are streams and the ESRP aquifer. Streams include the Big Lost River (BLR), Little Lost River (LLR), and BC that flow onto, or adjacent to, the INL from tributary valleys northwest of the INL (fig. 2). These streams are ephemeral on the ESRP, with annual discharge varying significantly (fig. 4) depending on the amount of annual precipitation in the surrounding mountains (Mundorff and others, 1963; Ackerman and others, 2006; U.S. Geological Survey, 2017). The LLR does not flow

\footnotetext{
${ }^{2}$ The smectite group of clay minerals includes the clay minerals montmorillonite and beidellite (Deer and others, 1983).
} 


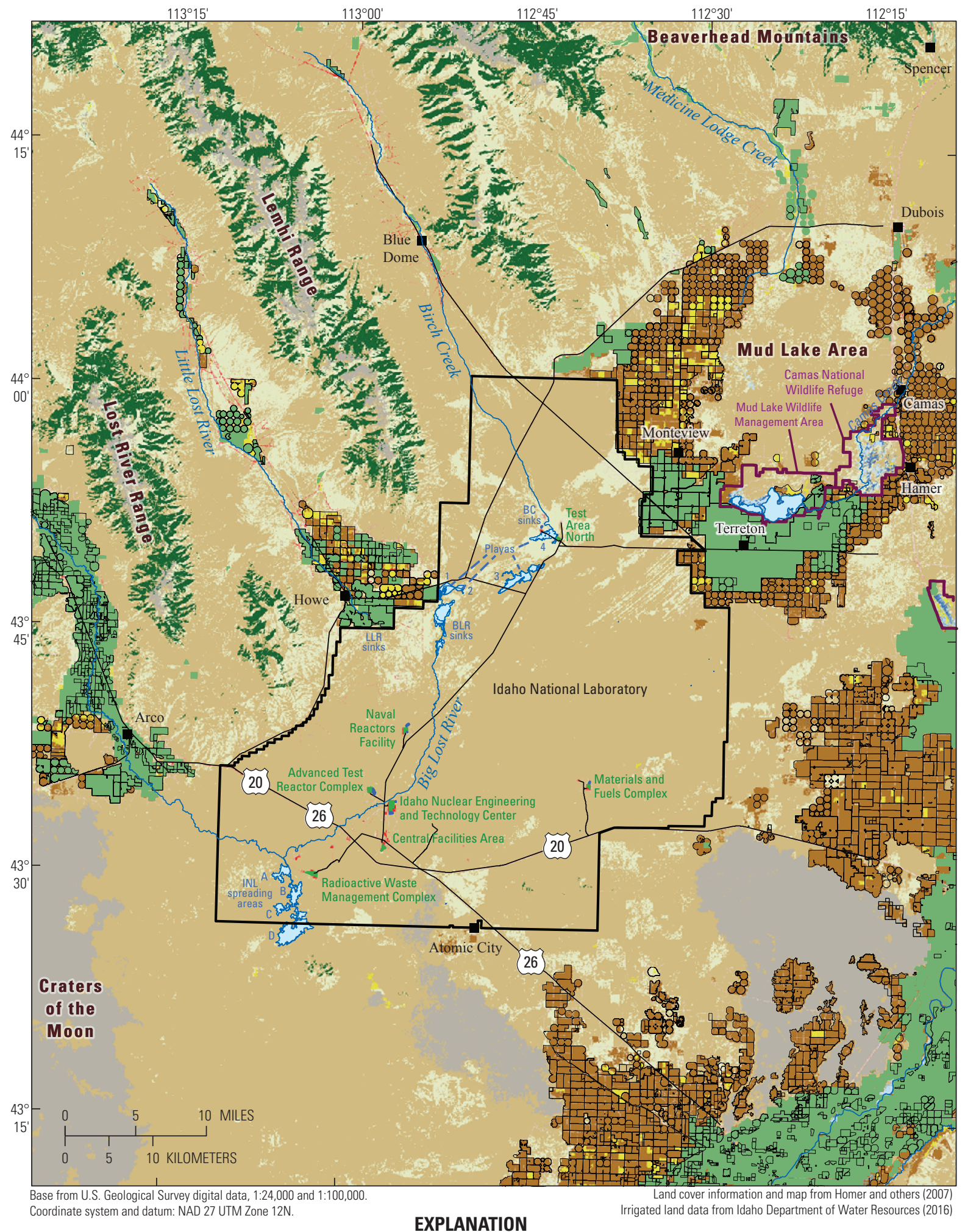

Land cover

\begin{tabular}{|c|c|}
\hline Grassland & Pasture \\
\hline Evergreen forest & Cultivated crops \\
\hline Shrub & Barren land \\
\hline
\end{tabular}

\section{Irrigated lands}

Groundwater irrigation Surface-water irrigation Surface-water and groundwater irrigation

Figure 2. Land cover and irrigation, Idaho National Laboratory and vicinity, eastern Idaho. 


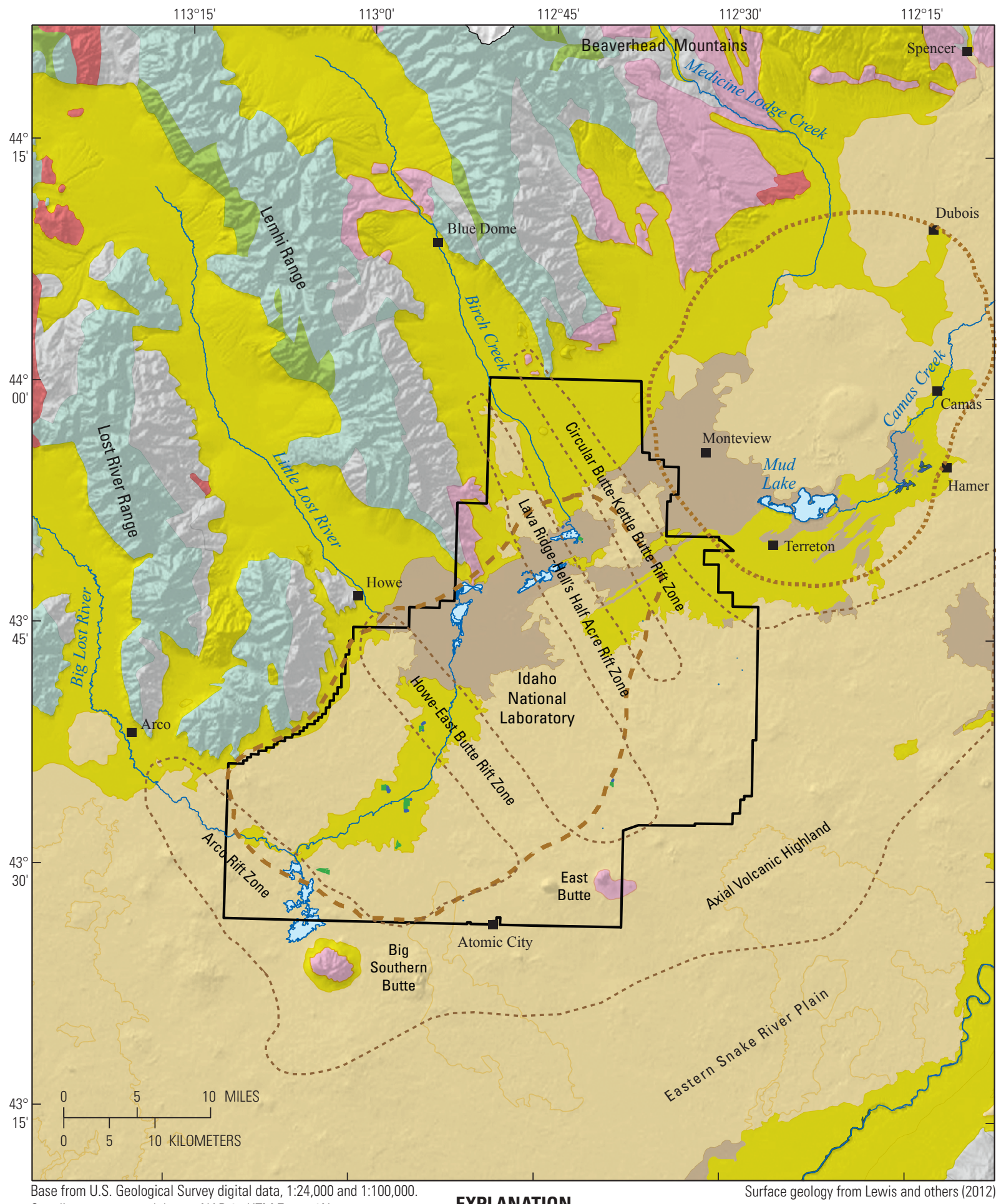

Coordinate system and datum: NAD 27 UTM Zone 12N___ EXPLANATION

Simplified surface geology
$\square$ Alluvial, fluvial, and eolian sediment
$\square$ Lacustrine sediment
$\square$ Basalt
$\square$ Rhyolite

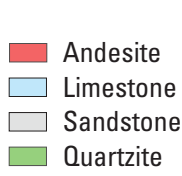

Structural features

Approximate extent of volcanioc rift zones and axial volcanic highland

[" = " Approximate extent of Mud Lake subbasin

- = - - " Approximate extent of Big Lost Trough subbasin

Figure 3. Surface geology and structural features, Idaho National Laboratory and vicinity, eastern Idaho. 
onto the INL and, due to construction of a diversion structure, only a small amount of flow in $\mathrm{BC}$ has reached has reached the INL since 1969 since 1969 (Kjelstrom and Berenbrock, 1996; Swanson and others, 2003). The BLR channel, sinks, playas, and spreading areas extend across much of the western, central, and northern parts of the INL (fig. 2). Mean annual discharge of the BLR onto the INL fluctuates between zero and greater than 100 cubic feet per second (ft3/s; fig. 4) in response to wet-dry climate cycles, with localized, episodic infiltration from the BLR occurring during wet climate cycles (Bennett, 1990). Consequently, the ESRP aquifer in the northern, central, and western parts of the INL is a dynamic system.

The ESRP aquifer at the INL is a heterogeneous, unconfined, fractured-basalt aquifer with an aquifer thickness estimated to range from several hundred to several thousand feet and an unsaturated zone thickness estimated to range from about 200 to $600 \mathrm{ft}$ (Ackerman and others, 2006). The aquifer is comprised of hundreds of interfingered layers of basalt and sediment, with the thickness of individual basalt flows estimated to range from 2 to $100 \mathrm{ft}$ (Anderson and Liszewski, 1997).

Recharge to the ESRP aquifer at and adjacent to the INL is from (1) rapid infiltration from the BLR, LLR, and $\mathrm{BC}$ from their channels and associated playas, sinks, and spreading areas (fig. 2) (Bennett, 1990; Busenberg and others,
2001; Nimmo and others, 2002; Swanson and others, 2003); (2) groundwater inflow from the tributary valley and mountain front aquifers northwest of the INL and the ESRP aquifer northeast of the INL (Ackerman and others, 2006); (3) infiltration of precipitation across the surface of the ESRP (Ackerman and others, 2006); (4) injection or infiltration of wastewater at INL facilities (Davis and others, 2013); and (5) upwelling of deep geothermal water (Mann, 1986; Rattray, 2015; Rattray, 2018). Most groundwater inflow to the study area is from regional groundwater in the ESRP aquifer northeast of the INL, with lesser amounts of inflow as tributary groundwater from alluvial aquifers in the BLR, LLR, and BC valleys (Ackerman and others, 2006). Groundwater inflow from mountain front aquifers and infiltration of precipitation are probably small sources of recharge, although recharge from precipitation may be locally important in small basins where precipitation may collect or in areas of bare basalt where precipitation may infiltrate rapidly (Garabedian, 1992; Busenberg and others, 2001). Recharge amounts from upward flow of geothermal water and discharge of wastewater are small but may have a significant influence on the chemistry of groundwater due to the spatially-concentrated nature and large solute concentration of this recharge (Spinazola, 1994; Anderson and others, 1999; Davis and others, 2013; Rattray, 2015).

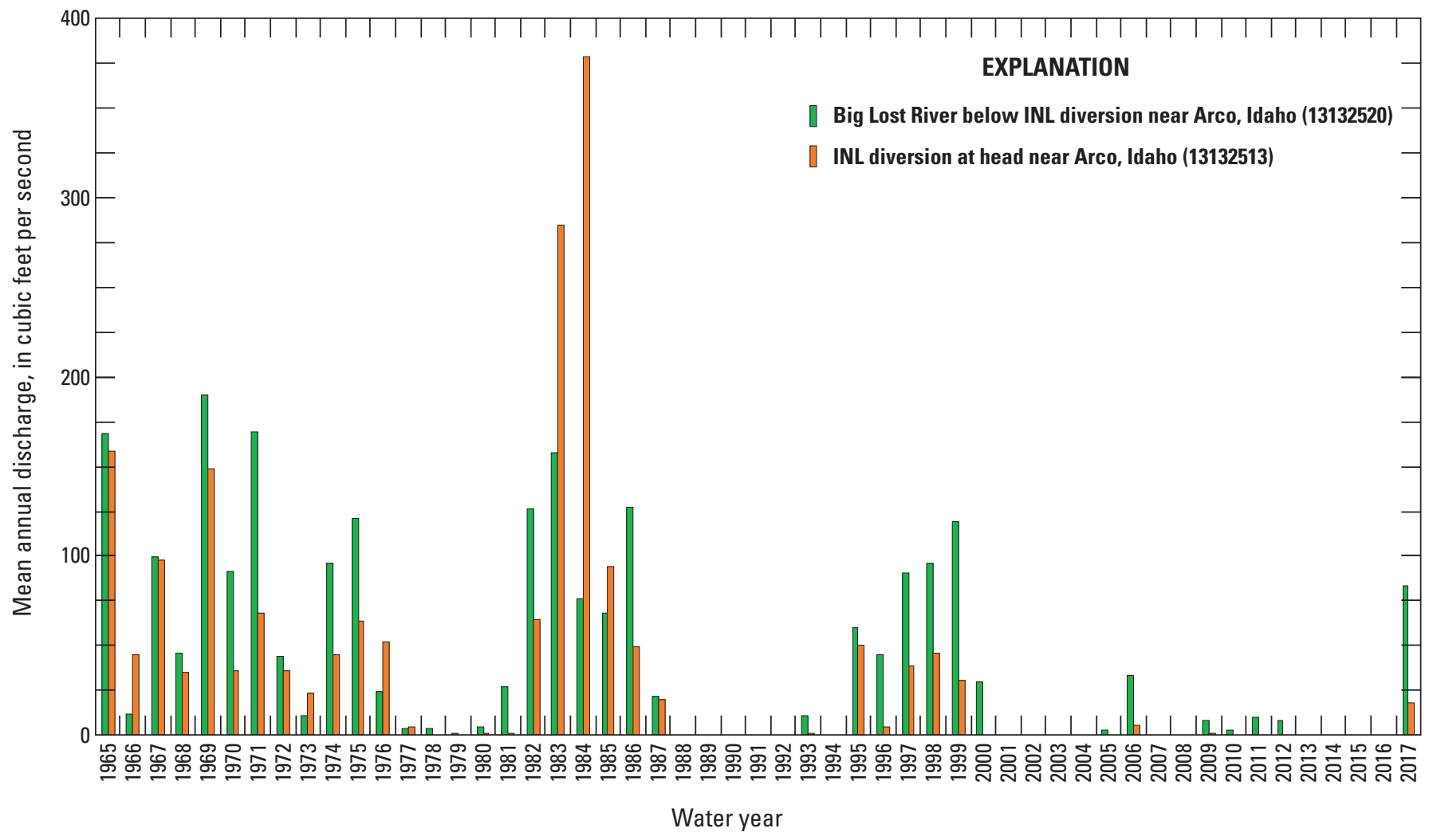

Figure 4. Mean annual discharge of the Big Lost River below INL diversion near Arco and INL diversion at head near Arco, Idaho National Laboratory, eastern Idaho. Streamgage locations shown in figure 1. A water year is the 12-month period from October 1, for any given year, through September 30 of the following year. The water year is designated by the calendar year in which it ends. 
Most groundwater flow in the aquifer is horizontal and occurs in the rubble- and sediment-filled interflow zones between basalt flows (Whitehead, 1992), although dikes associated with volcanic rift zones and vent corridors may impede horizontal flow (Anderson and others, 1999). Upward and downward vertical groundwater movement occurs in the aquifer (Mann, 1986; Ackerman and others, 2006; Rattray, 2015), but significant vertical movement is probably constrained to areas where vertical fractures are abundant (Whitehead, 1992) or where vertically-oriented fissures and dikes associated with volcanic rift zones or vent corridors are present. Perched groundwater zones have formed beneath the Advanced Test Reactor Complex (ATRC), Idaho Nuclear Technology and Engineering Center (INTEC), and Radioactive Waste Management Complex (RWMC) due to localized infiltration of water from the BLR and wastewater infiltration ponds and low permeability geologic materials impeding the downward movement of water (Cecil and others, 1991; Bartholomay and Tucker, 2000; Davis and others, 2013).

Porosity of the fractured basalts ranges from 0.05 to 0.27 , although these values are dependent upon scale and the methods used to determine them (Ackerman and others, 2006). However, porosity and permeability generally are low in the massive interiors of basalt flows and large in the interflow zones (Welhan, Clemo, and Grego, 2002; Welhan, Johannesen, and others, 2002; Ackerman and others, 2006). Hydraulic conductivities (K) estimated from single-well aquifer tests indicate that the aquifer has extreme heterogeneity in $\mathrm{K}$, with $\mathrm{K}$ ranging more than six orders of magnitude $(\log \mathrm{K}$ of -2.10 to 4.38 feet per day (ft/d); Rattray, 2018, table 11), although most hydraulic conductivities exceed log $\mathrm{K}$ values of $2 \mathrm{ft} / \mathrm{d}$ (Anderson and others, 1999). Average linear flow velocities, estimated from model ages of environmental tracers (Busenberg and others, 2001) and assumed first-arrival times of contaminants in groundwater (Barraclough and others, 1981; Pittman and others, 1988; Mann and Beasley, 1994; Cecil and others, 2000), range from 2 to $20 \mathrm{ft} / \mathrm{d}$ (Ackerman and others, 2006).

The variable distances from recharge areas for groundwater at different locations in the ESRP aquifer at the INL produce groundwater with different residence times. The oldest groundwater is in the eastern part of the INL where regional groundwater, estimated to have a residence time in the ESRP aquifer of 35-350 years (Rattray and Ginsbach, 2014), provides recharge to the INL. However, tritium activities and chlorofluorocarbon, sulfur hexafluoride $\left(\mathrm{SF}_{6}\right)$, and tritium/helium-3 $\left({ }^{3} \mathrm{H}-{ }^{3} \mathrm{He}\right)$ model ages show that most shallow groundwater at the INL contains some young groundwater (Busenberg and others, 2001; Rattray, 2018, table 17, fig. 13). For example, tritium activities indicate that groundwater in the northeast and north-central parts of the INL is old (pre-1952) groundwater, but that groundwater elsewhere at the INL is either young (post-1952) groundwater or a mixture of young and old groundwater (Rattray, 2018, fig. 28BB). The young mean age of groundwater at the
INL precludes determining groundwater ages with the few available carbon-14 values (Rattray, 2018, fig. 28DD).

Water-table contours for April 1989 for the ESRP aquifer were interpolated from 481 water-level measurements (fig. 5; water-level data presented in Rattray, 2018, table 1-1) using the natural neighbor technique (Sibson, 1981). Water-table contours indicate that groundwater in the aquifer generally flows south and southwest across the INL and that hydraulic gradients are relatively flat throughout the INL and relatively steep along the northwestern and northeastern boundaries of the INL and southwest of the INL. The steep hydraulic gradient northeast of the INL may reflect a decrease in hydraulic conductivity due to deposition of fine-grained sediments along the boundary of the Mud Lake subbasin (Ackerman and others, 2006) or impermeable volcanic structures associated with volcanic rift zones (fig. 3) or vent corridors (Rattray, 2015).

\section{Previous Investigations}

Geochemical mass-balance modeling and massbalance calculations were previously used to understand the geochemical processes influencing groundwater chemistry in the ERSP aquifer. Mass-balance models or calculations were made for (1) the entire ESRP aquifer, (2) drainage basins northwest of the INL, (3) the ESRP aquifer east of the INL, and (4) parts of the ESRP aquifer at the INL.

Geochemical mass-balance calculations were made for the entire ESRP aquifer (Wood and Low, 1988). These results indicated that calcite and silica precipitated from groundwater and that olivine, pyroxene, plagioclase, pyrite, and anhydrite dissolved from the aquifer framework.

Geochemical models of the BLR, LLR, and $\mathrm{BC}^{3}$ drainage basins (fig. 6) were developed by Carkeet and others (2001) and Swanson and others $(2002,2003)$, respectively. Groundwater in all these drainage basins was a $\mathrm{Ca}-\mathrm{Mg}-\mathrm{HCO}_{3}$-type water (water types are defined in Rattray, 2018). The geochemical models indicated that the chemistry of groundwater was controlled by carbonate reactions in the BLR drainage basin; carbonate reactions, nitrification of ammonium, and dissolution of inorganic fertilizers in the LLR drainage basin; and carbonate and silicate reactions in the $\mathrm{BC}$ drainage basin.

Geochemical models of the Camas and Medicine Lodge Creek drainage basins, which includes the southern parts of the Beaverhead and Centennial Mountains and the ESRP aquifer east of the INL (figs. 1 and 6), were developed by Ginsbach (2013), Rattray and Ginsbach (2014), and Rattray (2015). Non-geothermal groundwater from the mountains was either a $\mathrm{Ca}-\mathrm{HCO}_{3}$ or a $\mathrm{Ca}-\mathrm{Mg}-\mathrm{HCO}_{3}$-type water. Groundwater from the ESRP aquifer was a $\mathrm{Ca}-\mathrm{Mg}-\mathrm{HCO}_{3}$-type water or, if from the heavily-irrigated Mud Lake area of the ESRP aquifer (fig. 2), was various combinations of $\mathrm{Ca}-, \mathrm{Mg}-$, and (or) $\mathrm{Na}-\mathrm{HCO}_{3}$ type water and one $\mathrm{Ca}-\mathrm{Cl}-\mathrm{HCO}_{3}$-type water.

\footnotetext{
${ }^{3}$ The two sites farthest south in the BC drainage basin (Swanson and others, 2003) also were from the ESRP aquifer at the INL.
} 


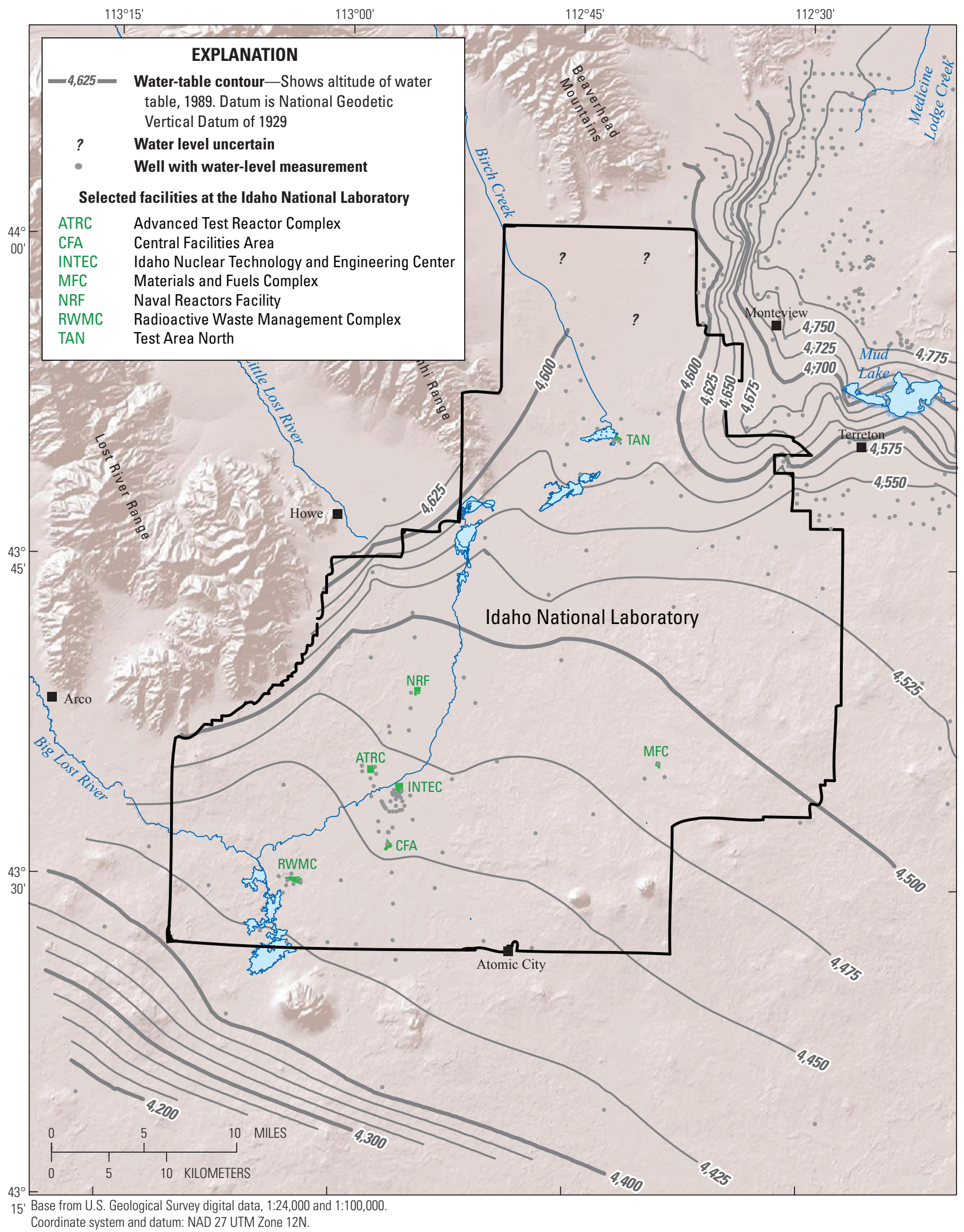

Figure 5. Locations of wells with water-level measurements and 1989 water-table contours, Idaho National Laboratory and vicinity, eastern Idaho. 


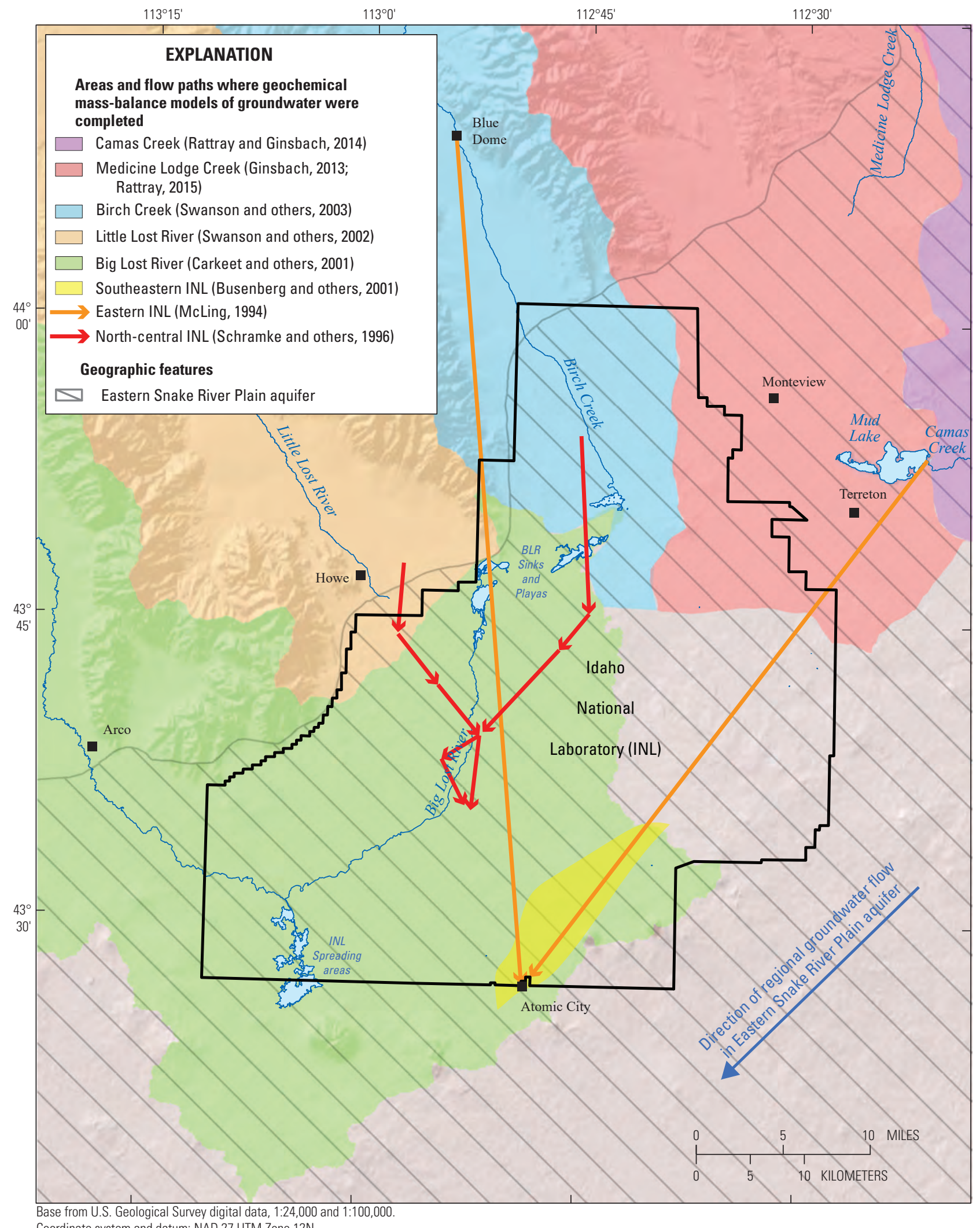

Coordinate system and datum: NAD 27 UTM Zone $12 \mathrm{~N}$

Figure 6. Areas and flow paths where geochemical mass-balance models of groundwater were previously done, at and adjacent to the Idaho National Laboratory, eastern Idaho. 
Geochemical models indicated that the chemistry of groundwater in the (1) mountains was controlled by carbonate and silicate reactions plus dissolution of gypsum; (2) ESRP aquifer east of the Mud Lake area was controlled by these reactions plus dissolution of halite and cation exchange; and (3) ESRP aquifer in the Mud Lake area was controlled by carbonate, silicate, and redox reactions, dissolution of evaporite minerals and fertilizer, cation exchange, and upwelling of deep geothermal water.

Geochemical models of parts of the ESRP aquifer at the INL (fig. 6) were developed by McLing (1994), Schramke and others (1996), and Busenberg and others (2001). McLing (1994) modeled mixing of water in the eastern part of the INL using Birch Creek, Mud Lake, and Heise Hot Springs (about $40 \mathrm{mi}$ east of the INL) as source waters and groundwater from the Atomic City well (in Atomic City) as the final water (fig. 1). A geochemical mixing model, with limited water-rock interaction, was produced that included 20 percent water from BC, 80 percent water from Mud Lake, and 0.4 percent geothermal water as sources of water. Chemical reactions, in order of importance, were dissociation of carbonic acid, precipitation of calcite, exchange of sodium for calcium and magnesium, and dissolution of pyroxene, olivine, and potassium feldspar. Schramke and others (1996) developed models of two north-to-south flow paths, with the paths originating at wells near the mouths of the LLR and $\mathrm{BC}$ drainage basins and terminating at wells in the central part of the INL. Their most reasonable models included mixing of surface water and groundwater from the BLR and the LLR drainage basins. Chemical reactions consisted of precipitation of calcite and montmorillonite and dissolution of silica, kaolinite, plagioclase, halite, and potassium feldspar. Busenberg and others (2001) modeled mixing of precipitation with regional groundwater for groundwater from eight wells in the southeastern part of the INL (fig. 6). Precipitation was assumed to be a source of water in this area due to the presence of chlorofluorocarbons, sulfur hexafluoride, and tritium $\left({ }^{3} \mathrm{H}\right)$ in the groundwater. The modeled fractions of precipitation and regional groundwater in these wells ranged from 21 to 44 and 56 to 79 percent, respectively. Chemical reactions primarily were precipitation of $\mathrm{Ca}$ - and (or) Na-smectite, ferric hydroxide, and gibbsite, precipitation or dissolution of calcite, and dissolution of carbon dioxide, plagioclase, halite, forsterite, pyrite, and potassium feldspar.

\section{Geochemistry Data}

The geochemistry data included in this study are a subset of the sample sites and geochemistry data presented in Chapter A of Professional Paper 1837 (Rattray, 2018) plus additional geochemistry data from sample sites representing precipitation (precipitation from Craters of the Moon [fig. 1; data references in headnotes to tables 6-8, at back of report] and snow cores from Site 9, USGS 22, and USGS 83 [Rightmire and Lewis, 1987]), groundwater south of the INL (Fingers Butte Well, Crossroads
Well, Houghland Well, Grazing Well \#2, and Grazing Service CCC \#3 [Bartholomay and others, 2001]), and recently-collected groundwater samples (USGS 143, USGS 146 [U.S. Geological Survey, 2017]) (fig. 7). The geochemistry data included in this study are measurements of field parameters and concentrations of dissolved gases and metals (table 6), concentrations of major ions and silica (table 7), and stable isotope ratios $\left(\delta^{2} \mathrm{H}, \delta^{18} \mathrm{O}\right.$, $\delta^{13} \mathrm{C}$ ) and tritium $\left({ }^{3} \mathrm{H}\right)$ activities (table 8 ). Sources of the data, methods of sample collection and analysis, and data quality for the geochemistry data from Chapter A of Professional Paper 1837 (Rattray, 2018) are presented in that report, and this information is in the cited references (and references therein) for the additional geochemistry data included in this report. Sample sites (table 1) were grouped into categories of water types as contaminated groundwater, deep groundwater, geothermal water, natural groundwater, precipitation, regional groundwater, surface water, and tributary valley groundwater. ${ }^{4}$

\section{Sources of Solutes}

Understanding the potential sources of solutes throughout the ESRP aquifer at the INL is an essential component in developing an accurate geochemical model of the aquifer system. Solutes in the ESRP aquifer at the INL are derived from natural recharge, anthropogenic inputs, and chemical reactions. Recharge provides the baseline concentrations of solutes in the ESRP aquifer at the INL, anthropogenic inputs provide large, localized inputs of solutes to the aquifer, and solute concentrations are modified by chemical reactions as groundwater moves through the aquifer. Solute concentrations also may be modified by dispersion, diffusion, and mixing of water (including mixing of water from different aquifer depths during pumping of long, open well intervals while collecting water samples; Rattray, 2018, table 11).

\section{Natural Recharge}

Natural recharge includes infiltration of surface water (precipitation, streams, and Mud Lake), groundwater inflow, and upwelling of deep geothermal water (Ackerman and others, 2006). Precipitation is only a small source of recharge at the INL. However, because precipitation is very dilute (table 7), where recharge of precipitation does occur, it should decrease concentrations of solutes in groundwater. Streams and Mud Lake typically are more dilute than groundwater at the INL (Rattray, 2018, table 12), and because infiltration recharge from streams and Mud Lake are spatially concentrated recharge from these sources may locally decrease concentrations of solutes in groundwater. The streams, along

\footnotetext{
${ }^{4}$ Definitions of water types highlighted in bold are presented in the Glossary and may reference data presented in Chapter A of Professional Paper 1837 (Rattray, 2018).
} 


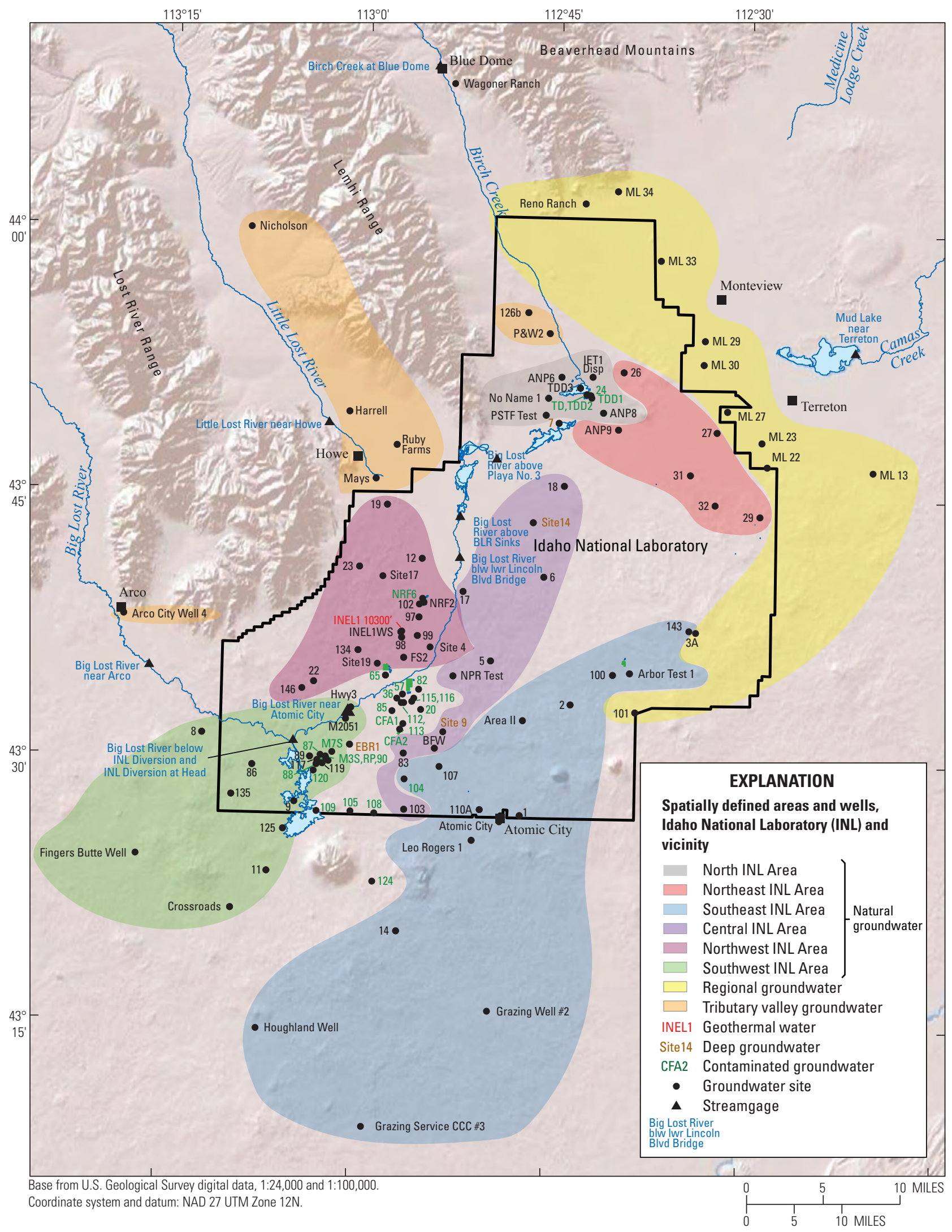

Figure 7. Locations of water-quality sample collection sites, Idaho National Laboratory and vicinity, eastern Idaho. Abbreviations for site names are shown in table 1. 
Table 1. Site names and numbers and abbreviated name for water-quality sample sites, Idaho National Laboratory and vicinity, eastern Idaho.

[Locations of sites shown in figures 1, 7, and 8. Abbreviations: USGS, U.S. Geological Survey; na, not applicable]

\begin{tabular}{lcc}
\hline $\begin{array}{c}\text { Site } \\
\text { name }\end{array}$ & \multicolumn{1}{c}{$\begin{array}{c}\text { USGS } \\
\text { site No. }\end{array}$} & $\begin{array}{c}\text { Abbreviated } \\
\text { name }\end{array}$ \\
\hline & Precipitation \\
\hline Rain and Snow \\
\hline Craters of the Moon & 432743113334001 & COM \\
\hline USGS 22 & Snow \\
USGS 83 & na & 22 \\
\hline
\end{tabular}

\section{Surface water}

\begin{tabular}{lll}
\hline Big Lost River at Mackay Dam & 13126000 & BLRMD \\
Big Lost River at Bridge near & 13127700 & BLRM \\
Mackay & & \\
$\begin{array}{l}\text { Big Lost River near Arco } \\
\text { Big Lost River below INL }\end{array}$ & 13132500 & BLRA \\
$\quad$ Diversion & & BLRINL \\
Big Lost River below lower & 13132520 & \\
$\quad$ Lincoln Boulevard Bridge & & BLRLB \\
$\quad$ near Howe & & \\
Birch Creek at Kaufman & 13116980 & BCKGS \\
$\quad$ Guard Station & & \\
$\begin{array}{l}\text { Birch Creek at Blue Dome } \\
\text { Little Lost River near Clyde }\end{array}$ & 13117020 & BC \\
Little Lost River near Howe & 13117500 & LLRC \\
Mud Lake near Terreton & 13115000 & LLR \\
\hline
\end{tabular}

\begin{tabular}{|c|c|c|}
\hline \multicolumn{3}{|c|}{ Tributary valley groundwater } \\
\hline \multicolumn{3}{|c|}{ Big Lost River Valley } \\
\hline Arco City Well 4 & 433758113181701 & ACW4 \\
\hline \multicolumn{3}{|c|}{ Little Lost River Valley } \\
\hline Harrell & 434940113005601 & na \\
\hline Mays & 434558112585301 & na \\
\hline Nicholson & 440003113085101 & na \\
\hline Ruby Farms & 434751112571801 & RF \\
\hline \multicolumn{3}{|c|}{ Birch Creek Valley } \\
\hline P\&W 2 & 435419112453101 & $\mathrm{P} \& \mathrm{~W} 2$ \\
\hline USGS $126 b$ & 435529112471401 & $126 \mathrm{~b}$ \\
\hline \multicolumn{3}{|c|}{ Regional groundwater } \\
\hline ML 13 & 434624112194601 & ML13 \\
\hline ML 22 & 434657112282201 & ML22 \\
\hline ML 27 & 435003112313101 & ML27 \\
\hline ML 29 & 435402112332101 & ML29 \\
\hline ML 33 & 435831112365401 & ML33 \\
\hline ML 34 & 440226112402401 & ML34 \\
\hline Reno Ranch & 440142112425501 & $\mathrm{RR}$ \\
\hline USGS 3A & 433732112335401 & $3 \mathrm{~A}$ \\
\hline USGS 101 & 433255112381801 & 101 \\
\hline
\end{tabular}

\begin{tabular}{lll}
\hline & Geothermal water \\
\hline INEL-1 2,000 feet & 433717112563501 & INEL1 2000 \\
INEL-1 10,300 feet & 433717112563501 & INEL1 10300
\end{tabular}

\begin{tabular}{|c|c|c|}
\hline $\begin{array}{c}\text { Site } \\
\text { name }\end{array}$ & $\begin{array}{c}\text { USGS } \\
\text { site No. }\end{array}$ & $\begin{array}{c}\text { Abbreviated } \\
\text { name }\end{array}$ \\
\hline \multicolumn{3}{|c|}{ Groundwater at the Idaho National Laboratory } \\
\hline \multicolumn{3}{|c|}{ Deep groundwater } \\
\hline EBR 1 & 433051113002601 & EBR1 \\
\hline Site 9 & 433123112530101 & Site9 \\
\hline Site 14 & 434334112463101 & Site14 \\
\hline USGS 7 & 434915112443901 & 7 \\
\hline USGS 15 & 434234112551701 & 15 \\
\hline \multicolumn{3}{|c|}{ Contaminated groundwater } \\
\hline \multicolumn{3}{|c|}{ Advanced Test Reactor Complex } \\
\hline USGS 65 & 433447112574501 & 65 \\
\hline \multicolumn{3}{|c|}{ Idaho Nuclear Technology and Engineering Center } \\
\hline CFA 1 & 433204112562001 & CFA1 \\
\hline CFA 2 & 433144112563501 & CFA2 \\
\hline USGS 20 & 433253112545901 & 20 \\
\hline USGS 36 & 433330112565201 & 36 \\
\hline USGS 57 & 433344112562601 & 57 \\
\hline USGS 82 & 433401112551001 & 82 \\
\hline USGS 85 & 433246112571201 & 85 \\
\hline USGS 104 & 432856112560801 & 104 \\
\hline USGS 105 & 432703113001801 & 105 \\
\hline USGS 108 & 432659112582601 & 108 \\
\hline USGS 112 & 433314112563001 & 112 \\
\hline USGS 113 & 433314112561801 & 113 \\
\hline USGS 115 & 433320112554101 & 115 \\
\hline USGS 116 & 433331112553201 & 116 \\
\hline USGS 124 & 432307112583101 & 124 \\
\hline \multicolumn{3}{|c|}{ Naval Reactors Facility } \\
\hline NRF 6 & 433910112550101 & NRF6 \\
\hline NRF 9 & 433840112550201 & NRF9 \\
\hline NRF 10 & 433841112545201 & NRF10 \\
\hline NRF 11 & 433847112544201 & NRF11 \\
\hline NRF 12 & 433855112543201 & NRF12 \\
\hline NRF 13 & 433928112545401 & NRF13 \\
\hline \multicolumn{3}{|c|}{ Radioactive Waste Management Complex } \\
\hline RWMC M3S & 433008113021801 & M3S \\
\hline RWMC M7S & 433023113014801 & M7S \\
\hline RWMC Production & 433002113021701 & $\mathrm{RP}$ \\
\hline USGS 87 & 433013113024201 & 87 \\
\hline USGS 88 & 432940113030201 & 88 \\
\hline USGS 90 & 432954113020501 & 90 \\
\hline USGS 109 & 432701113025601 & 109 \\
\hline USGS 120 & 432919113031501 & 120 \\
\hline \multicolumn{3}{|c|}{ Test Area North } \\
\hline TAN Disposal & 435053112423201 & $\mathrm{TD}$ \\
\hline TDD 1 & 435042112420901 & TDD1 \\
\hline TDD 2 & 435054112423201 & TDD2 \\
\hline USGS 24 & 435053112420801 & 24 \\
\hline
\end{tabular}


Table 1. Site names and numbers and abbreviated name for water-quality sample sites, Idaho National Laboratory and vicinity, eastern Idaho.-Continued

\begin{tabular}{|c|c|c|c|c|c|}
\hline $\begin{array}{c}\text { Site } \\
\text { name }\end{array}$ & $\begin{array}{c}\text { USGS } \\
\text { site No. }\end{array}$ & $\begin{array}{c}\text { Abbreviated } \\
\text { name }\end{array}$ & $\begin{array}{c}\text { Site } \\
\text { name }\end{array}$ & $\begin{array}{c}\text { USGS } \\
\text { site No. }\end{array}$ & $\begin{array}{c}\text { Abbreviated } \\
\text { name }\end{array}$ \\
\hline \multicolumn{3}{|c|}{ Groundwater at the Idaho National Laboratory—Continued } & \multicolumn{3}{|c|}{ Groundwater at the Idaho National Laboratory—Continued } \\
\hline \multicolumn{3}{|c|}{ Natural groundwater } & \multicolumn{3}{|c|}{ Natural groundwater-Continued } \\
\hline \multicolumn{3}{|c|}{ North INL } & \multicolumn{3}{|c|}{ Northwest INL } \\
\hline ANP 6 & 435152112443101 & ANP6 & Fire Station 2 & 433548112562301 & FS2 \\
\hline ANP 8 & 434952112411301 & ANP8 & INEL-1 WS & 433716112563601 & INEL1 \\
\hline IET 1 Disposal & 435153112420501 & IET1 Disp & NRF 2 & 433854112545401 & NRF2 \\
\hline No Name 1 & 435038112453401 & $\mathrm{NN} 1$ & NRF 7 & 433920112543601 & NRF7 \\
\hline PSTF Test & 434941112454201 & PSTF & NRF 8 & 433843112550901 & NRF8 \\
\hline TDD 3 & 435116112430301 & TDD3 & Site 4 & 433617112542001 & Site4 \\
\hline \multicolumn{3}{|c|}{ Northeast INL } & Site 17 & 434027112575701 & Site17 \\
\hline ANP 9 & 434856112400001 & ANP9 & $\begin{array}{l}\text { Site } 19 \\
\text { USGS } 12\end{array}$ & 433522112582101 & Site19 \\
\hline USGS 26 & 435212112394001 & 26 & $\begin{array}{l}\text { USGS } 12 \\
\text { USGS } 19\end{array}$ & $\begin{array}{l}434126112550701 \\
434426112575701\end{array}$ & $\begin{array}{l}12 \\
19\end{array}$ \\
\hline USGS 27 & 434851112321801 & 27 & $\begin{array}{l}\text { USGS } 19 \\
\text { USGS } 22\end{array}$ & 433422113031701 & 22 \\
\hline USGS 29 & 434407112285101 & 29 & USGS 23 & 434055112595901 & 23 \\
\hline USGS 31 & 434625112342101 & 31 & USGS 97 & 433807112551501 & 97 \\
\hline USGS 32 & 434444112322101 & 32 & USGS 98 & 433657112563601 & 98 \\
\hline \multicolumn{3}{|c|}{ Southeast INL } & USGS 99 & 433705112552101 & 99 \\
\hline Arbor Test 1 & 433509112384801 & AT1 & USGS 102 & 433853112551601 & 102 \\
\hline Area II & 433223112470201 & A2 & USGS 134 & 433611112595819 & 134 \\
\hline Atomic City & 432638112484101 & $\mathrm{AC}$ & USGS 146 & 433359113042501 & 146 \\
\hline Grazing Service CCC \#3 & 430911112585401 & GS3 & \multicolumn{3}{|c|}{ Southwest INL } \\
\hline Grazing Well \#2 & 431553112492001 & GW2 & Crossroads & 432128113092701 & Crssrds \\
\hline Houghland Well & 431439113071401 & Hghlnd & Fingers Butte Well & 432424113165301 & FBW \\
\hline Leo Rogers 1 & 432533112504901 & LR1 & Highway 3 & 433256113002501 & Hwy3 \\
\hline USGS 1 & 432700112470801 & 1 & Middle 2051 & 433217113004905 & M2051 \\
\hline USGS 2 & 433320112432301 & 2 & USGS 8 & 433121113115801 & 8 \\
\hline USGS 14 & 432019112563201 & 14 & USGS 9 & 432740113044501 & 9 \\
\hline USGS 100 & 433503112400701 & 100 & USGS 11 & 432336113064201 & 11 \\
\hline USGS 107 & 432942112532801 & 107 & USGS 86 & 432935113080001 & 86 \\
\hline USGS 110A & 432717112501502 & $110 \mathrm{~A}$ & USGS 89 & 433005113032801 & 89 \\
\hline USGS 143 & 433736112341301 & 143 & USGS 117 & 432955113025901 & 117 \\
\hline \multicolumn{3}{|c|}{ Central INL } & USGS 119 & 432945113023401 & 119 \\
\hline Badging Facility Well & 433042112535101 & BFW & USGS 125 & 432602113052801 & 125 \\
\hline NPR Test & 433449112523101 & NPR & USGS 135 & 432753113093613 & 135 \\
\hline USGS 5 & 433543112493801 & 5 & & & \\
\hline USGS 6 & 434031112453701 & 6 & & & \\
\hline USGS 17 & 433937112515401 & 17 & & & \\
\hline USGS 18 & 434540112440901 & 18 & & & \\
\hline USGS 83 & 433023112561501 & 83 & & & \\
\hline USGS 103 & 432714112560701 & 103 & & & \\
\hline
\end{tabular}

with the primary sources of water to Mud Lake, originate in carbonate terrane in the mountains northwest, north, and northeast of the INL (fig. 3), where the geology limits the groundwater concentrations of $\mathrm{Na}, \mathrm{K}, \mathrm{Cl}, \mathrm{NO}_{3}$, and $\mathrm{SiO}_{2}$ (table 7). Concentrations of these chemical species may significantly decrease in ESRP groundwater influenced by recharge from streams and Mud Lake. Recharge from infiltration of precipitation, surface water, or irrigation return flows may also transport $\mathrm{O}_{2}$ from the atmosphere, $\mathrm{CO}_{2}$ from the unsaturated zone, and nitrogen from the soil zone (from wet and dry atmospheric deposition; Nilles, 2000; Rattray and Sievering, 2001) to the aquifer, and may cause a localized increase in natural groundwater concentrations of these chemical species.

Groundwater inflow to the ESRP aquifer at and near the INL occurs from tributary valleys north of the INL and regional groundwater northeast of the INL. Tributary valley and regional groundwater flows through carbonate and silicate 
terranes, respectively, and $\mathrm{Ca}-\mathrm{HCO}_{3}$-type water is typical for both types of terranes. However, due to the influence of irrigation, regional groundwater adjacent to the northeast INL boundary (fig. 2) is a mixed cation- $\mathrm{HCO}_{3}$ type water (fig. 8; Rattray and Ginsbach, 2014; Rattray, 2018). Concentrations of $\mathrm{SiO}_{2}$ are not affected by irrigation, and $\mathrm{SiO}_{2}$ concentrations in regional groundwater are about double the concentrations in tributary valley groundwater (table 7).

Recharge from upward-moving geothermal water at and near the INL was identified by Mann (1986) and Rattray $(2015,2018)$. An upward flux of geothermal water of $20 \mathrm{ft}^{3} / \mathrm{s}$ was estimated across the $890-\mathrm{mi}^{2}$ area of the INL (Mann,
1986; Ackerman and others, 2006). However, geochemical modeling indicated that geothermal water in the ESRP aquifer adjacent to the INL only occurs in localized areas (Rattray, 2015), perhaps due to deep, open fissures associated with volcanism on the ESRP (Anderson and others, 1999). Geothermal water sampled from thousands of feet beneath the INL is brackish and is a Na- $\mathrm{HCO}_{3}$-type water (Mann, 1986; Rattray, 2018, fig. 10A), so even small amounts of localized recharge of geothermal water would affect solute concentrations in groundwater at the INL.

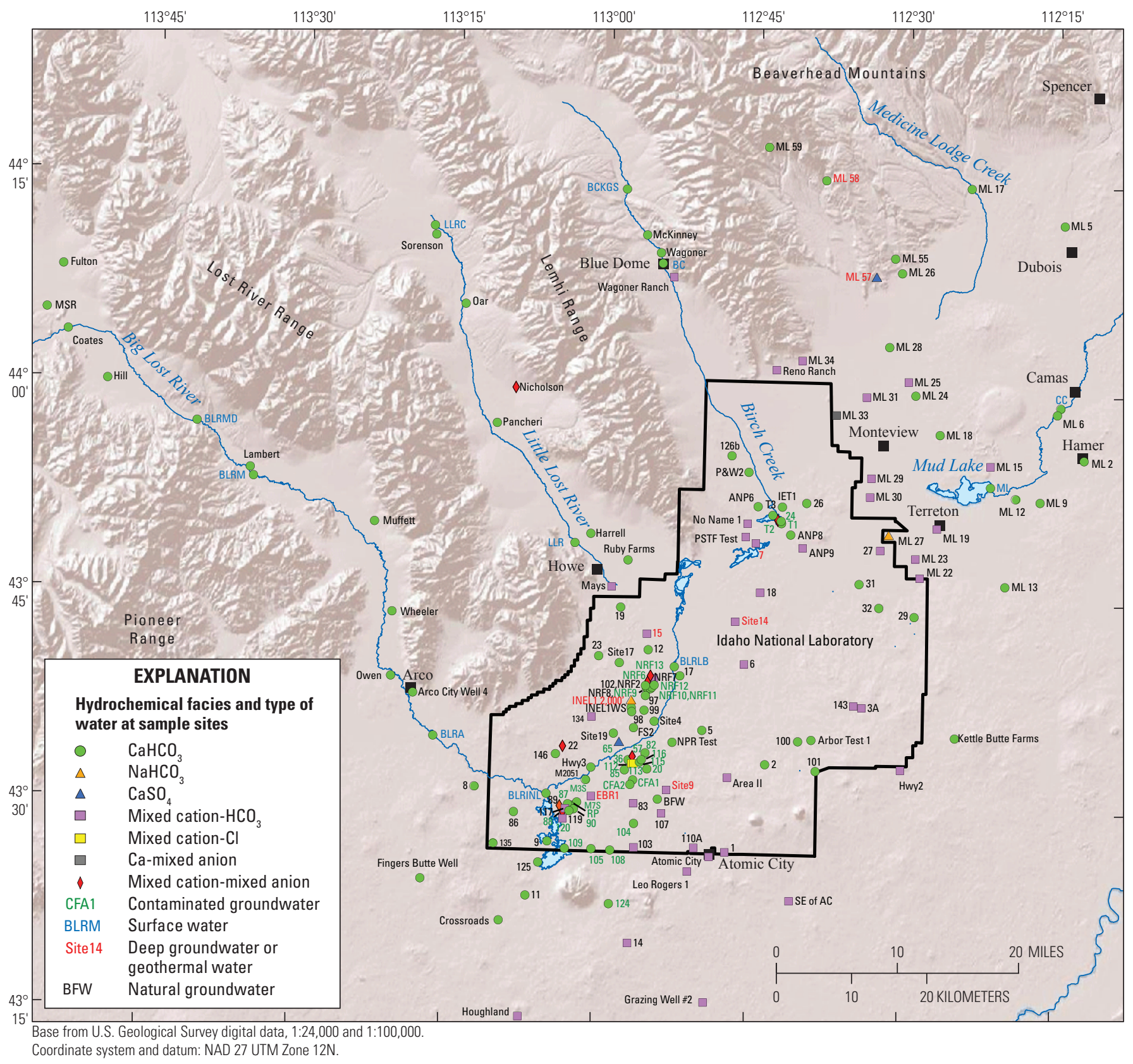

Figure 8. Hydrochemical facies of surface water and groundwater, Idaho National Laboratory and vicinity, eastern Idaho. Abbreviations for site names are shown in table 1. 


\section{Anthropogenic Inputs}

Anthropogenic inputs potentially affecting groundwater in the ESRP aquifer at the INL include wastewater discharge at INL facilities, irrigation in the Howe and Mud Lake areas, and road salt applied to roads at the INL (fig. 2). Wastewater discharge affects the chemistry of groundwater at and downgradient of INL facilities. For example, discharge in wastewater of large concentrations of $\mathrm{Ca}^{2+}, \mathrm{Na}^{+}, \mathrm{Cl}^{-}, \mathrm{SO}_{4}^{2-}$ and large activities of ${ }^{3} \mathrm{H}$ produce large concentrations of some of these constituents in contaminated groundwater at and downgradient of INTEC and at the ATRC, Naval Reactors Facility (NRF), RWMC, and Test Area North (TAN) (Rattray, 2018). Anthropogenic inputs from the dissolution of agricultural soil amendments (gypsum, inorganic fertilizer) and road salt $(\mathrm{NaCl})$ are discussed in section, "Dissolution of Anthropogenic Inputs."

\section{Chemical Reactions}

Chemical reactions that occur in the ESRP aquifer and unsaturated zone include water-rock interactions, dissolution of anthropogenic chemicals such as agricultural soil amendments and road salt applied to the land surface, and redox reactions between groundwater, dissolved gases, and particulate or organic material (Rattray, 2015). Chemical reactions are driven by the thermodynamic state of water and its solutes, as well as that of the other relevant phases contacting the water, including the minerals that compose the aquifer matrix. Water-rock interaction occurs throughout the ESRP aquifer. Solutes may be released from, or sorbed or precipitated onto, the aquifer matrix. Dissolution of agricultural soil amendments is limited to irrigated lands in the Howe and Mud Lake areas, and dissolution of road salt is limited to areas near roads. The ESRP aquifer is a well-oxygenated system (table 6), although water with reducing conditions occurs where discharge of organic compounds in wastewater or recharge of anoxic geothermal water produce redox reactions.

\section{Water-Rock Interaction}

The thermodynamic state of water (precipitation, surface water, groundwater, and geothermal water) was evaluated by calculating the mineral-water thermodynamic saturation index ${ }^{5}$ (SI) of water samples with respect to selected minerals (table 9, at back of report). Saturation indices were calculated using the computer code PHREEQC (Parkhurst and Appelo, 2013), the thermodynamic databases wateq4f.dat (for the minerals clinoenstatite, diopside, forsterite, and sodium beidellite) and phreeqc.dat (for all other minerals in table 9) provided with PHREEQC, and the chemical composition of water samples (tables 6-7). Saturation indices less than -0.1 indicate that the water is undersaturated with respect to the mineral (the mineral may dissolve into solution), SIs greater than 0.1 indicate that the water is supersaturated with respect to the

\footnotetext{
${ }^{5}$ The equation for calculating saturation indices is presented in appendix 1.
}

mineral (the mineral may precipitate from solution), and SIs of $-0.1-0.1$ indicate that the water is in approximate equilibrium with the mineral (the mineral may dissolve or precipitate).

Saturation indices were calculated for water samples with respect to plagioclase (albite, anorthite), pyroxene (clinoenstatite, diopside), olivine (forsterite), volcanic glass (represented with amorphous silica), evaporate minerals (gypsum, halite, fluorite, sylvite), potassium feldspar, carbonate minerals (dolomite, calcite), clay minerals (calcium montmorillonite, sodium beidellite), goethite, and quartz (table 9). Precipitation and snow were undersaturated with respect to all minerals. ${ }^{6}$ Surface water and the groundwater sample from the BLR valley (Arco City Well 4) were undersaturated with respect to plagioclase, pyroxene, forsterite, amorphous silica, evaporate minerals, and potassium feldspar; supersaturated with respect to goethite and quartz; and undersaturated, supersaturated, or in equilibrium with respect to dolomite, calcite, and clay minerals. All other groundwater was undersaturated with respect to plagioclase, pyroxene, forsterite, amorphous silica, and evaporate minerals; supersaturated with respect to clay minerals, goethite, and quartz; and undersaturated, supersaturated, or in equilibrium with respect to potassium feldspar, dolomite, and calcite.

\section{Carbonate Reactions}

Dissolution of carbonate minerals occurs in the aquifer, or in the unsaturated zone, because calcite and dolomite are present in surficial and interbed sediments and these minerals rapidly dissolve in solution. Calcite may also precipitate from supersaturated solutions, but precipitation of dolomite is kinetically unfavorable in the ESRP aquifer (Rattray and Ginsbach, 2014). Dissolution of calcite or dolomite will consume $\mathrm{CO}_{2}$ while releasing $\mathrm{Ca}, \mathrm{Mg}$ (from dolomite), and $\mathrm{HCO}_{3}$ to solution (table 2). Precipitation of calcite is the reverse reaction. ${ }^{7}$

The spatial distribution of SIs for calcite for groundwater in the study area, as well as additional tributary valley and regional groundwater presented in Rattray (2018), is shown in figure 9. Most regional groundwater is undersaturated or in approximate equilibrium with respect to calcite and most tributary valley groundwater is either supersaturated or in approximate equilibrium with calcite. Of the 100 deep, contaminated, and natural groundwater samples collected at and south of the INL, 94 samples are supersaturated, 3 are in approximate equilibrium, and 3 are undersaturated with respect to calcite. This distribution of SIs for calcite, plus the mostly supersaturated state of groundwater at the INL with respect to dolomite (table 9), shows that the dominant carbonate reaction in groundwater at the INL should be precipitation of calcite.

\footnotetext{
${ }^{6}$ Measurements of aluminum and iron were not made from precipitation samples, so SIs were not calculated for feldspars, clays, and goethite.

${ }^{7}$ Molar ratios of $\mathrm{Mg}^{2+}: \mathrm{Ca}^{2+}$ of less than 1 in groundwater at the INL indicate that $\mathrm{CaCO}_{3}$, and not $\mathrm{Ca}_{\mathrm{x}} \mathrm{Mg}_{1-\mathrm{x}} \mathrm{CO}_{3}$, is the carbonate mineral that should precipitate in the aquifer (Knobel and others, 1997).
} 
Table 2. Chemical reactions that may act as sources or sinks of gases and solutes to or from groundwater, Idaho National Laboratory and vicinity, eastern Idaho.

[Ex, exchanging substrate]

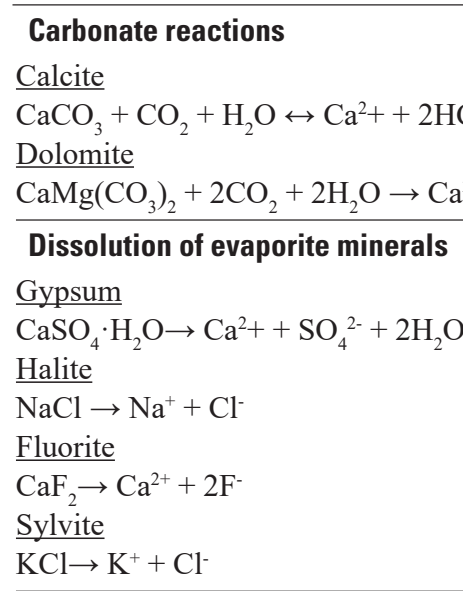

\section{Weathering of silicate minerals}

Plagioclase $\left(\mathrm{An}_{60}\right)$ to Ca-montmorillonite

$\mathrm{Ca}_{0.6} \mathrm{Na}_{0.4} \mathrm{Al}_{1.6} \mathrm{Si}_{2.4}^{60} \mathrm{O}_{8}+0.13 \mathrm{H}_{4} \mathrm{SiO}_{4}+1.36 \mathrm{CO}_{2}+1.12 \mathrm{H}_{2} \mathrm{O} \rightarrow 0.69 \mathrm{Ca}_{0.17} \mathrm{Al}_{2.33} \mathrm{Si}_{3.67} \mathrm{O}_{10}(\mathrm{OH})_{2}+0.48 \mathrm{Ca}^{2+}+0.4 \mathrm{Na}^{+}+1.36 \mathrm{HCO}_{3}^{-}$

Plagioclase $\left(\mathrm{An}_{25}\right)$ to Na-montmorillonite

$\mathrm{Ca}_{0.25} \mathrm{Na}_{0.75} \mathrm{Al}_{1.25} \mathrm{Si}_{2.75} \mathrm{O}_{8}+1.07 \mathrm{CO}_{2}+2.64 \mathrm{H}_{2} \mathrm{O} \rightarrow 0.54 \mathrm{Na}_{0.33} \mathrm{Al}_{2.33} \mathrm{Si}_{3.67} \mathrm{O}_{10}(\mathrm{OH})_{2}+0.78 \mathrm{H}_{4} \mathrm{SiO}_{4}+0.25 \mathrm{Ca}^{2+}+0.57 \mathrm{Na}^{+}+1.07 \mathrm{HCO}_{3}^{-}$

Volcanic glass (basalt) to $\mathrm{Ca}$-montmorillonite

$\mathrm{SiAl}_{0.08} \mathrm{Fe}_{0.19} \mathrm{Mg}_{0.1} \mathrm{Ca}_{0.26} \mathrm{Na}_{0.03} \mathrm{~K}_{0.01} \mathrm{O}_{2.69}+1.12 \mathrm{CO}_{2}+2.36 \mathrm{H}_{2} \mathrm{O} \rightarrow$

$0.034 \mathrm{Ca}_{0.17} \mathrm{Al}_{2.33} \mathrm{Si}_{3.67} \mathrm{OO}_{10}(\mathrm{OH})_{2}+0.88 \mathrm{H}_{4} \mathrm{SiO}_{4}+0.19 \mathrm{Fe}^{2+}+0.1 \mathrm{Mg}^{2+}+0.25 \mathrm{Ca}^{2+}+0.03 \mathrm{Na}^{+}+0.01 \mathrm{~K}^{+}+1.12 \mathrm{HCO}_{3}^{-}$

Volcanic glass (rhyolite) to Na-montmorillonite

$\mathrm{SiAl}_{0.05} \mathrm{~K}_{0.03} \mathrm{Na}_{0.02} \mathrm{O}_{2.10}+0.04 \mathrm{CO}_{2}+1.87 \mathrm{H}_{2} \mathrm{O} \rightarrow 0.021 \mathrm{Na}_{0.33} \mathrm{Al}_{2.33} \mathrm{Si}_{3.67} \mathrm{O}_{10}(\mathrm{OH})_{2}+0.92 \mathrm{H}_{4} \mathrm{SiO}_{4}+0.03 \mathrm{~K}^{+}+0.01 \mathrm{Na}^{+}+0.04 \mathrm{HCO}_{3}^{-}$

Dissolution of Olivine (Forsterite, $\mathrm{Fo}_{85}$ )

$\mathrm{Mg}_{1.7} \mathrm{Fe}_{0.3} \mathrm{SiO}_{4}+4 \mathrm{CO}_{2}+4 \mathrm{H}_{2} \mathrm{O} \rightarrow 1.7 \mathrm{Mg}^{2+}+0.3 \mathrm{Fe}^{2+}+4 \mathrm{HCO}_{3}^{-}+\mathrm{H}_{4} \mathrm{SiO}_{4}$

Dissolution of Pyroxene (Augite)

$\mathrm{Ca}_{0.68} \mathrm{Mg}_{0.78} \mathrm{Fe}_{0.54} \mathrm{Si}_{2} \mathrm{O}_{6}+4 \mathrm{CO}_{2}+6 \mathrm{H}_{2} \mathrm{O} \rightarrow 0.68 \mathrm{Ca}^{2+}+0.78 \mathrm{Mg}^{2+}+0.54 \mathrm{Fe}^{2+}+4 \mathrm{HCO}_{3}^{-}+2 \mathrm{H}_{4} \mathrm{SiO}_{4}$

Potassium feldspar to Kaolinite

$\mathrm{KAlSi}_{3} \mathrm{O}_{8}+\mathrm{CO}_{2}+5.5 \mathrm{H}_{2} \mathrm{O} \rightarrow 0.5 \mathrm{Al}_{2} \mathrm{Si}_{2} \mathrm{O}_{5}(\mathrm{OH})_{4}+2 \mathrm{H}_{4} \mathrm{SiO}_{4}+\mathrm{K}^{+}+\mathrm{HCO}_{3}^{-}$

\section{Precipitation of goethite}

$\mathrm{Fe}^{3+}+2 \mathrm{H}_{2} \mathrm{O} \rightarrow \mathrm{FeOOH}+3 \mathrm{H}^{+}$

Cation exchange

$2 \mathrm{Na}-\mathrm{Ex}+\mathrm{Ca}^{2+} \leftrightarrow \mathrm{Ca}-\mathrm{Ex}+2 \mathrm{Na}^{+}$

\section{Dissolution of anthropogenic inputs}

Inorganic fertilizer (ammonium nitrate)

$\mathrm{NH}_{4} \mathrm{NO}_{3}+2 \mathrm{O}_{2} \rightarrow 2 \mathrm{NO}_{3}^{-}+2 \mathrm{H}^{+}+\mathrm{H}_{2} \mathrm{O}$

$\underline{\text { Road salt }}$

$\mathrm{NaCl} \rightarrow \mathrm{Na}^{+}+\mathrm{Cl}^{-}$

\section{Redox reactions}

$\underline{\text { Oxidation of organic matter }}$

$\mathrm{CH}_{2} \mathrm{O}+\mathrm{O}_{2} \rightarrow \mathrm{CO}_{2}+\mathrm{H}_{2} \mathrm{O}$

Oxidation of methane

$\mathrm{CH}_{4}+2 \mathrm{O}_{2} \rightarrow \mathrm{CO}_{2}+2 \mathrm{H}_{2} \mathrm{O}$ 


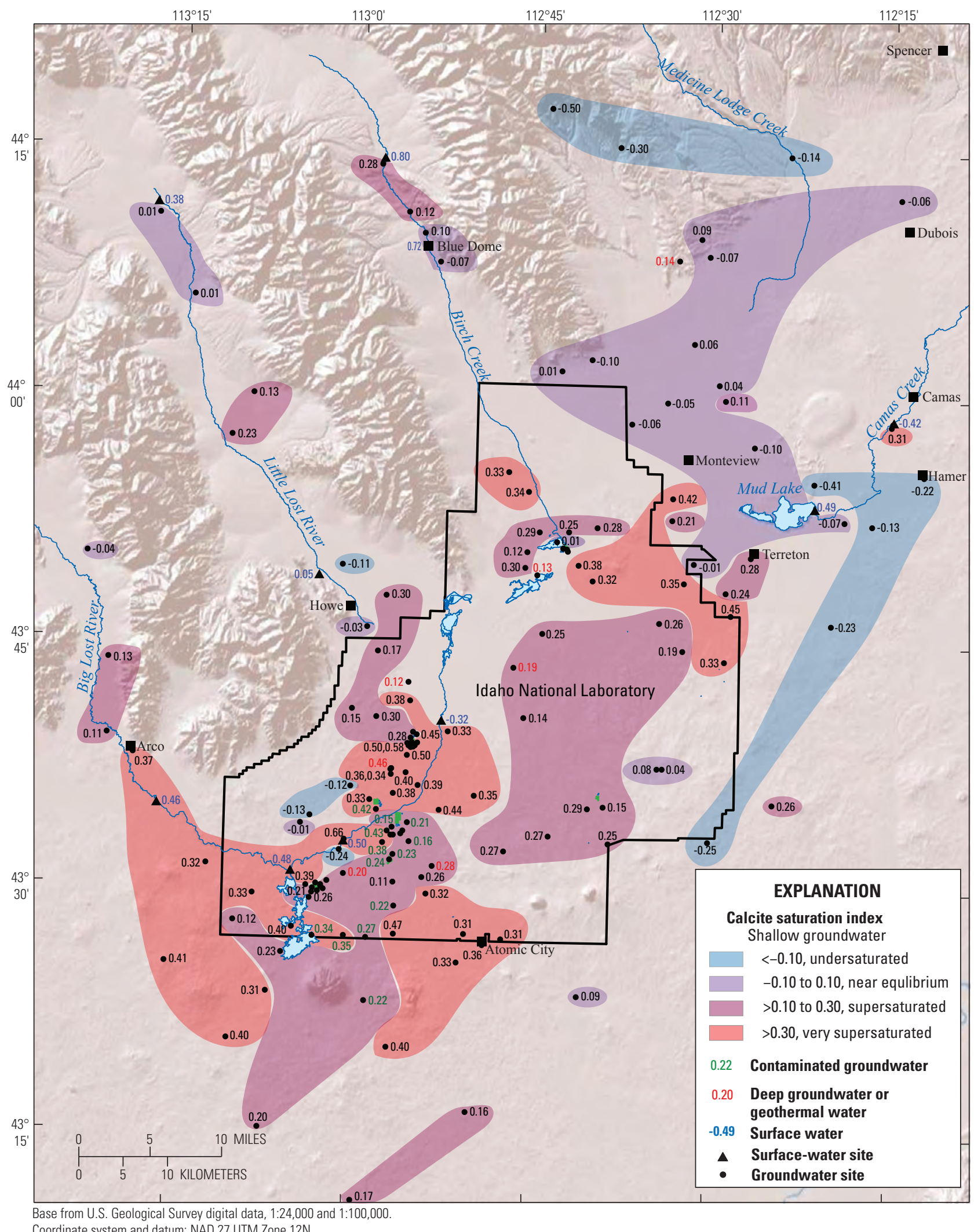

Figure 9. Saturation indices for calcite for surface water and groundwater, Idaho National Laboratory and vicinity, eastern Idaho. 


\section{Dissolution of Evaporite Minerals}

Gypsum present in sediment at the INL may be associated with "ancient evaporative playas or evaporative marginal lacustrine environments" (Geslin and others, 2002, p. 23). These evaporative environments occurred in the Big Lost Trough and the Mud Lake subbasins (fig. 3), which were periodically filled with water as Pleistocene Lake Terreton advanced and receded in response to glacial and interglacial periods (Gianniny and others, 2002; Mark and Thackray, 2002). Evaporite minerals may be rare or nonexistent at the INL outside of the Big Lost Trough and the Mud Lake subbasins (fig. 3).

Gypsum is the only evaporite mineral that has been identified in surficial or interbed sediment at the INL, but other evaporite minerals such as halite, fluorite, and sylvite also may have been deposited. These evaporate minerals are undersaturated in all surface water and groundwater at the INL, rapidly dissolve in solution, and may release $\mathrm{Ca}^{2+}, \mathrm{SO}_{4}^{2-}$, $\mathrm{Na}^{+}, \mathrm{Cl}^{-}, \mathrm{F}^{-}$, and $\mathrm{K}^{+}$to solution (table 2 ).

\section{Weathering of Silicate Minerals}

The silicate minerals that compose the aquifer (plagioclase, pyroxene, olivine, volcanic glass, potassium feldspar) were always (plagioclase, pyroxene, olivine, and volcanic glass; represented with albite, anorthite, clinoenstatite, diopside, forsterite, and amorphous silica in table 9) or frequently (potassium feldspar) undersaturated in groundwater at the INL and may chemically weather (dissolve) through hydrolysis reactions (table 2). However, most silicate minerals dissolve slowly in groundwater due to kinetic and (or) diffusive limitations on the rate of dissolution (Gronow, 1987; Lasaga and others, 1994). Dissolution rates for these minerals, from calculations of the mean lifetime of $1 \mathrm{~mm}$ crystals in a dilute solution at $25^{\circ} \mathrm{C}$ and $\mathrm{pH}$ of $5(\mathrm{pH}$ dependence of dissolution rates is slight at near-neutral $\mathrm{pH}$ of 4-8), were on the order of $10^{2}$ years for anorthite, $10^{3}$ years for forsterite, $10^{4}$ years for pyroxene, and $10^{5}$ years for potassium feldspar (Lasaga and others, 1994). Volcanic glass should dissolve rapidly because it is metastable due to its lack of crystallinity and large surface area (Deutsch and others, 1982).

Because of the slow rates of dissolution for silicate minerals, except for volcanic glass, the amount of dissolution of silicate minerals as groundwater flows through the INL should be small. This interpretation is supported by the fresh, unaltered appearance of most basalt mineral grains in the shallow ESRP aquifer (Nace and others, 1956), although alteration of basalt minerals is evident in deeper parts of the aquifer (Doherty and others, 1979; Mazurek, 2004). The silicate minerals most likely to undergo some dissolution in the shallow aquifer were those minerals having the most rapid dissolution rates, such as volcanic glass, plagioclase, and olivine (table 2). Alteration of volcanic glass was described as conversion to a mass of opaque minerals and pyroxene, and the rims of olivine crystals were observed to alter to opaque minerals or iddingsite (Nace and others, 1956; Lanphere and others, 1993). Rightmire and Lewis (1987) suggested that ferric oxyhydroxide in sediment may be related to weathering of olivine and pyroxene.

Plagioclase is an aluminosilicate mineral that should dissolve incongruently to produce ions in solution and a secondary aluminosilicate mineral (Knobel and others, 1997). Knobel and others (1997) suggested that the secondary aluminosilicate mineral formed by incongruent dissolution of plagioclase was smectite because authigenic smectite was observed in basalt (Wood and Low, 1988) and conditions favorable for smectite formation are present in the ESRP aquifer (Rightmire and Lewis, 1987). The specific smectite mineral forming as an alteration product has not been well defined, but calcic and sodic plagioclase in basalt $\left(\mathrm{An}_{50-70}\right)$ and rhyolite $\left(\mathrm{An}_{10-45}\right)$, respectively, should weather to calcium and sodium smectite (such as calcium and sodium montmorillonite; Knobel and others, 1997, figs. 15-20).

Groundwater at the INL has high average linear velocities (Ackerman and others, 2006). High groundwater velocities, combined with slow dissolution rates for silicate minerals, could produce nearly uniform silica concentrations in natural groundwater at the INL. However, silica concentrations and SIs for amorphous silica increase across the INL in a northwest (North and Northwest INL Areas) to southeast (Northeast and Southeast INL Areas) direction (figs. 10-11). The increase in silica concentrations and SIs for amorphous silica are due to the different geologic terranes where groundwater in the ESRP aquifer originates and the residence time of the groundwater. For example, recharge sources to the northern, central, and western parts of the INL are from tributary streams and tributary valley groundwater; therefore, groundwater in these parts of the INL originates in carbonate terrane and has a short residence time in the ESRP aquifer. Regional groundwater, which provides recharge to the eastern part of the INL, originates in carbonate mountains northeast of the INL but has had a long residence time in the silicate terrane of the ESRP aquifer (Rattray and Ginsbach, 2014). The greater dissolution of volcanic glass and silicate minerals in regional groundwater and natural groundwater in the eastern part of the INL was due to the longer residence time of this groundwater in a silicate terrane (that is, the ESRP aquifer) relative to that of natural groundwater in the northern, central, and western parts of the INL.

Stability diagrams were prepared to identify which clay minerals (kaolinite and smectites) are thermodynamically stable relative to the composition of surface-water and groundwater samples. On a stability diagram representing stable fields for kaolinite and calcium montmorillonite, nearly all groundwater samples plot in the calcium montmorillonite field, a few surface-water samples and one BC valley groundwater sample plot in the kaolinite field, and several surface-water and groundwater samples plot along the line representing equilibrium between kaolinite and calcium 


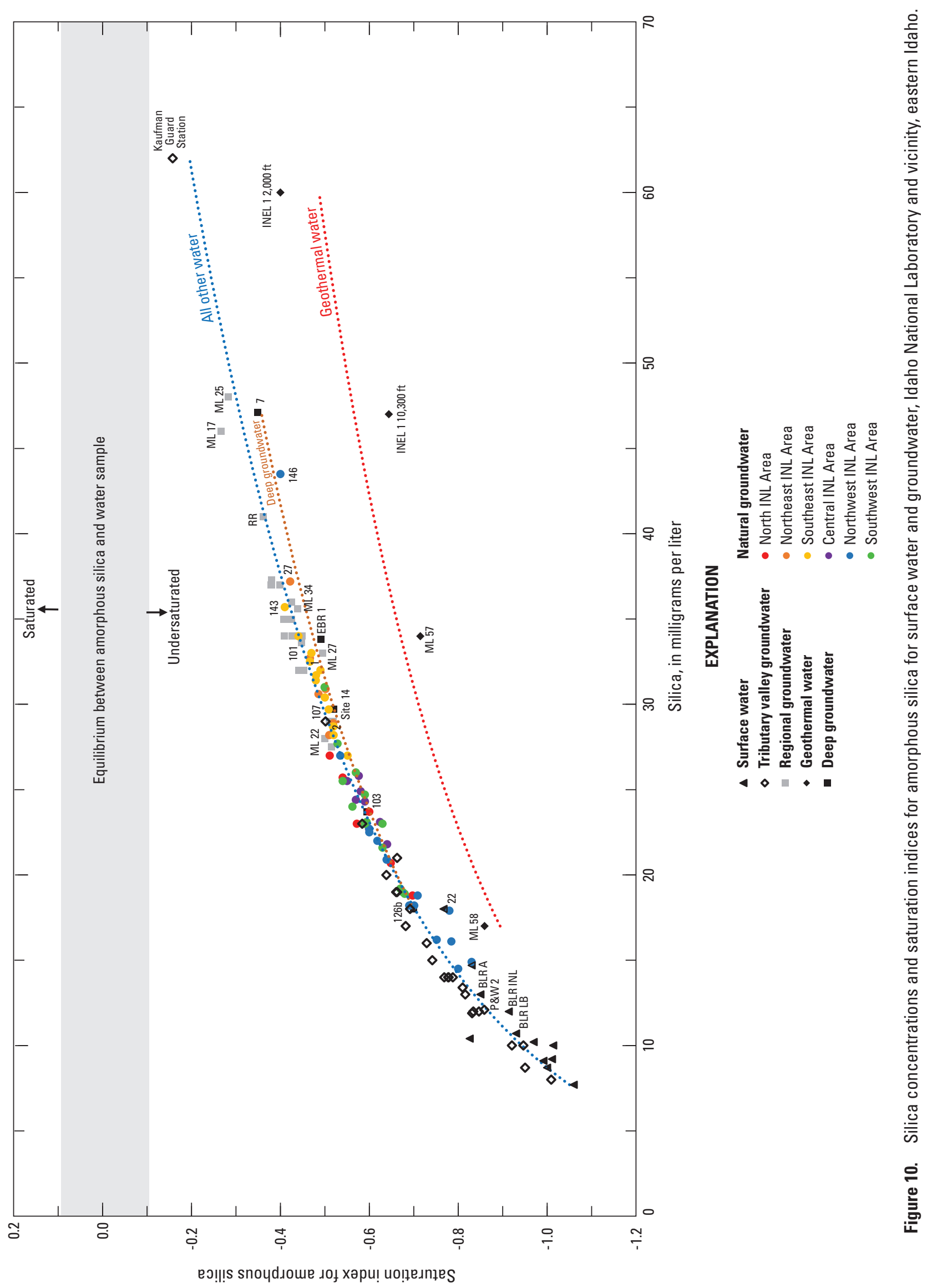




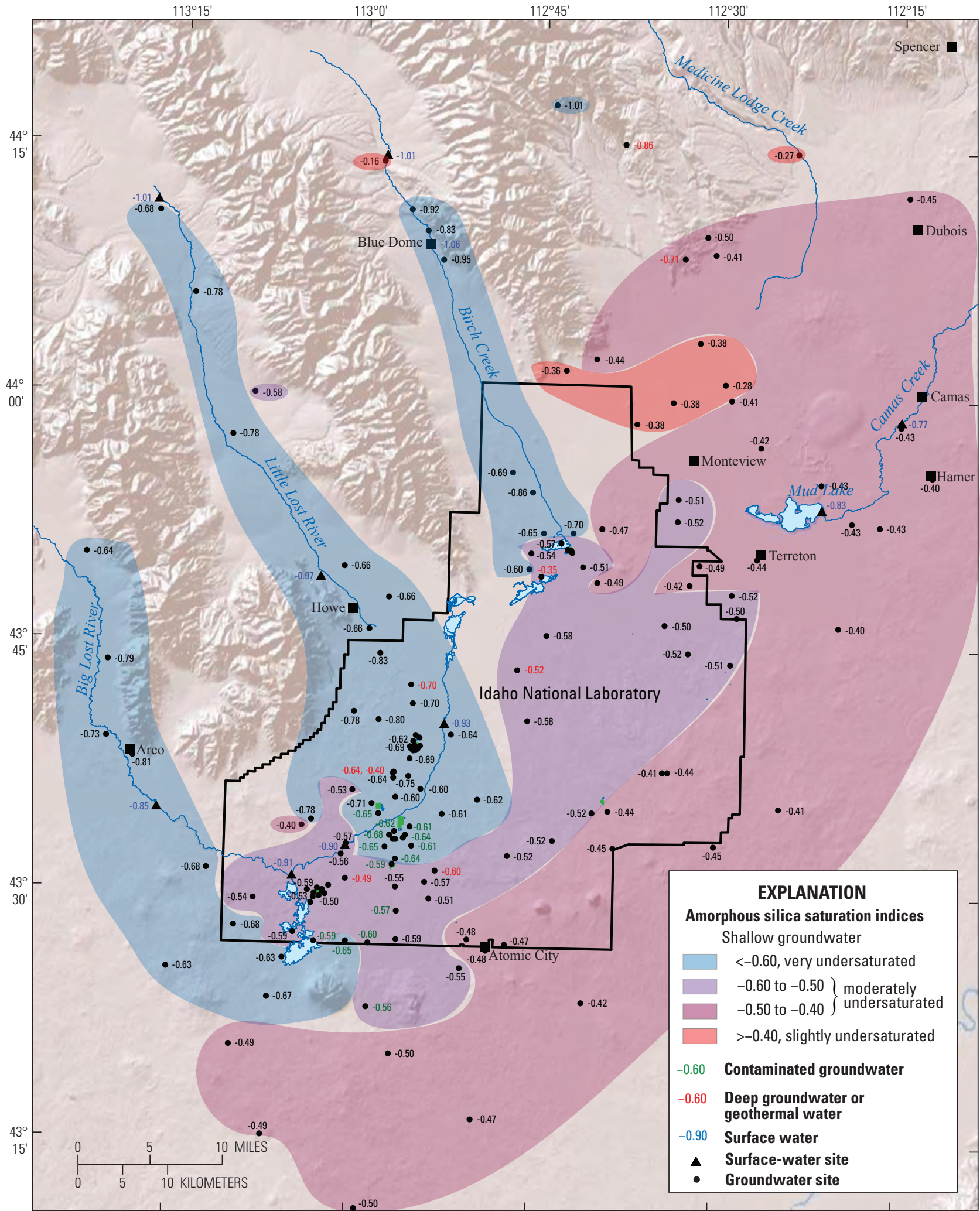

Base from U.S. Geological Survey digital data, 1:24,000 and 1:100,000.

Coordinate system and datum: NAD 27 UTM Zone 12N.

Figure 11. Saturation indices for amorphous silica for surface water and groundwater, Idaho National Laboratory and vicinity, eastern Idaho. 
montmorillonite (fig. 12). ${ }^{8}$ On a stability diagram prepared for calcium and sodium beidellite, all water samples except geothermal water from INEL-1 plot in the calcium beidellite field (fig. 13).

${ }^{8}$ The stability diagrams were created using The Geochemist's Workbench ${ }^{\circledR}$ computer code and the thermos.tdat database provided with the code (Bethke and Yeakel, 2017).

\section{Precipitation of Goethite}

Ferrous iron released from weathering of olivine, pyroxene, and basaltic glass (table 2) becomes oxidized to ferric iron and forms opaque minerals (Nace and others, 1956; Lanphere and others, 1993), such as ferric oxyhydroxide (Rightmire and Lewis, 1987). Ferric oxyhydroxide was represented in PHREEQC with goethite, and precipitation of iron oxyhydroxides makes solutions more acidic (table 2).

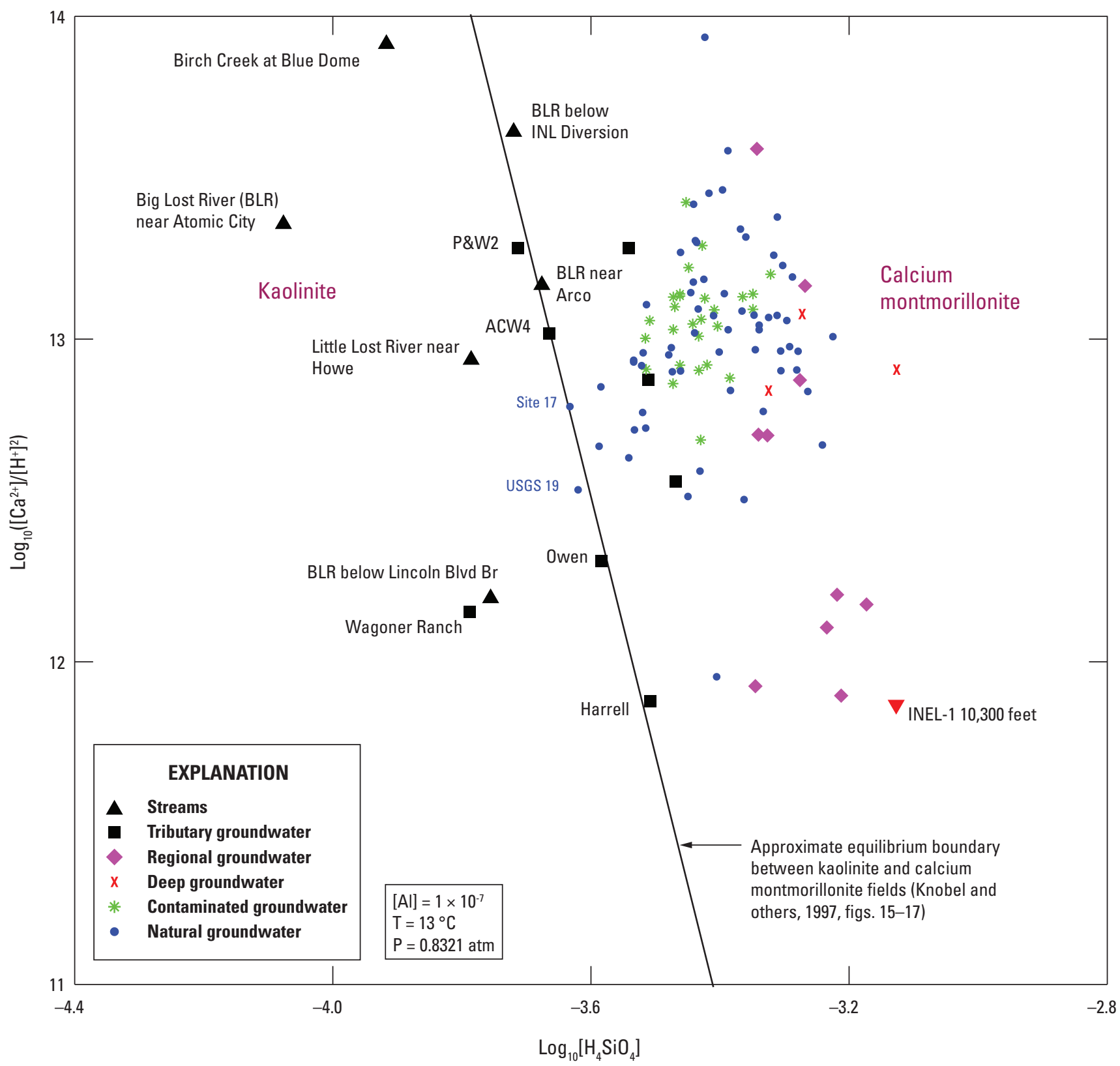

Figure 12. Stability relations between kaolinite and calcium montmorillonite with superposed compositions of water samples, Idaho National Laboratory and vicinity, eastern Idaho. Brackets indicate thermodynamic activity of indicated species. The equilibrium boundary line between kaolinite and calcium montmorillonite is after Knobel and others (1997, figs. 15-17). 


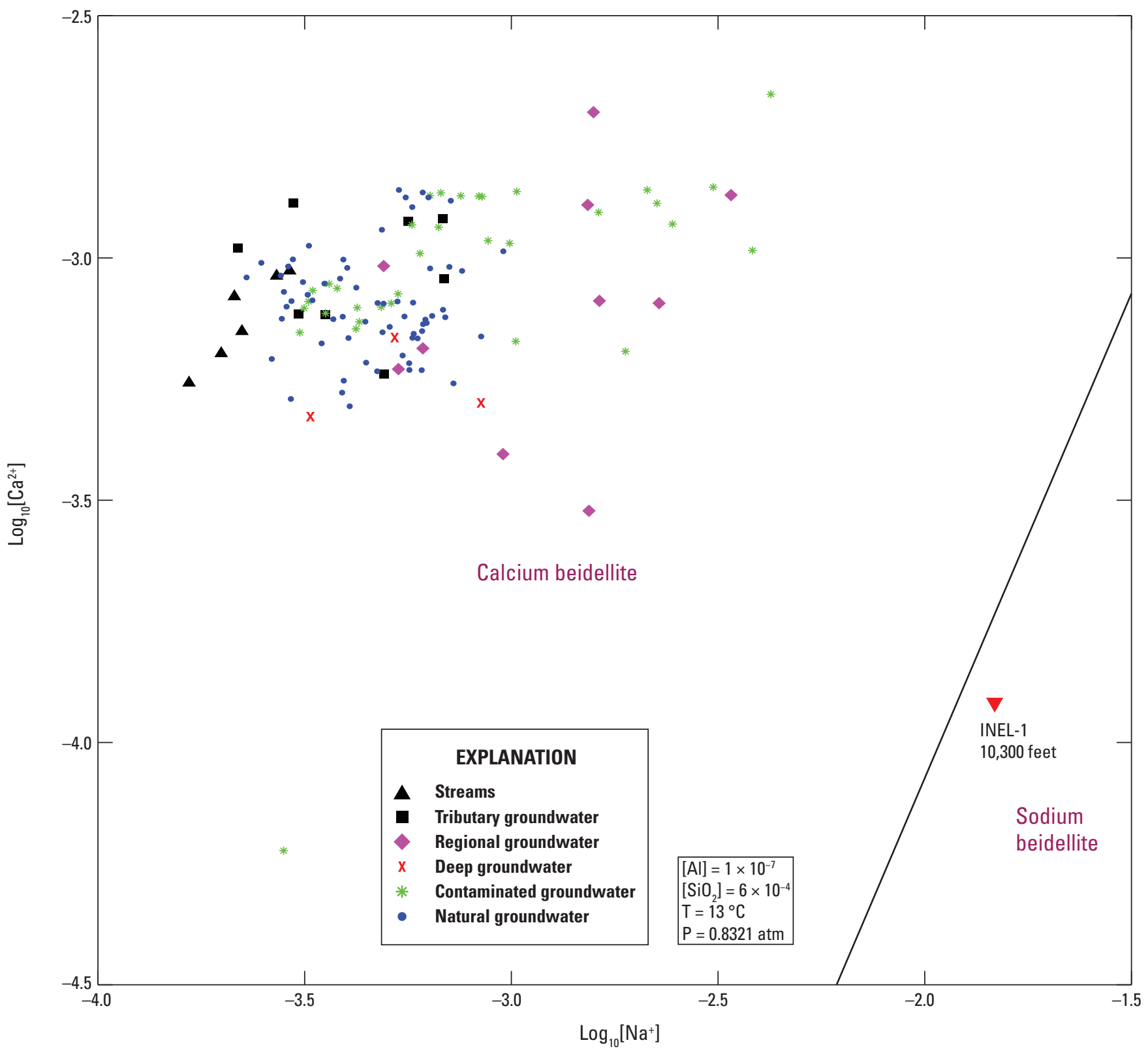

Figure 13. Stability relations between calcium beidellite and sodium beidellite with superposed compositions of water samples, Idaho National Laboratory and vicinity, eastern Idaho. Brackets indicate thermodynamic activity of indicated species.

\section{Cation Exchange}

Cation exchange involves "the displacement of one cation species from an exchanging-material surface and its replacement by another species from aqueous solution" (Chapelle and Knobel, 1983, p. 344). Many clay minerals are efficient exchanger materials. The most abundant clays at the ESRP aquifer at the INL are illite and montmorillonite, and these clays have large cation-exchange capacities (CEC) of 10-40 and $80-150$ milliequivalents per 100 grams (meq/100g) of rock (Drever, 1997), respectively. Due to the presence of illite and montmorillonite, the measured CEC of sediment at INL was as large as $45 \mathrm{meq} / 100 \mathrm{~g}$ (Bartholomay and others, 1989).

The affinity of cations for exchange sites is related to the size of the hydrated radii and the strength of the bond between the cation and clay surface or layer. Cations with smaller radii are held more strongly to exchange sites than cations with larger radii, and bonds formed with divalent cations are more stable than bonds with monovalent cations. Thus, in water where $\mathrm{Ca}^{2+}, \mathrm{Mg}^{2+}, \mathrm{K}^{+}$, and $\mathrm{Na}^{+}$are the dominant cations, such as the ESRP aquifer, the order of cation affinity for exchange sites is $\mathrm{Ca}^{2+}>\mathrm{Mg}^{2+}>\mathrm{K}^{+}>\mathrm{Na}^{+}$(Chapelle and Knobel, 1983). 
The affinity of cations for exchange sites also is related to the activities of cations on exchange sites and in solution. ${ }^{9}$ In dilute groundwater where the dominant cation is $\mathrm{Ca}^{2+}$, such as natural groundwater at the INL (fig. 8 ), $\mathrm{Ca}^{2+}$ should be the primary cation removed from solution during ion exchange. Additionally, during monovalent-divalent cation exchange, such as for $\mathrm{Na}^{+}-\mathrm{Ca}^{2+}$, the squared term for the monovalent cation in a mass action equation (eq. 1-4) for a dilute solution results in $\mathrm{Ca}^{2+}$ having a much greater affinity for the exchange sites than $\mathrm{Na}^{+}$(Drever, 1997, p. 84). However, as the activity of the monovalent cation increases relative to the divalent cation, the affinity of the monovalent cation for exchange sites increases and may exceed the affinity of the divalent cation for exchange sites. This process, known as reverse ion exchange (Swanson and others, 2003), has been shown to occur at Phoenix, Arizona, in areas irrigated with water from the Salt River (Hem, 1992, p. 96), and may occur at the INL in areas where irrigation or wastewater discharge produce large $\mathrm{Na}^{+}$ activities in groundwater (Rattray, 2018, fig. 28I).

\section{Dissolution of Anthropogenic Inputs}

Irrigation in the Howe and Mud Lake areas (fig. 2) affects ion concentrations in groundwater at the INL because (1) these areas are hydrologically upgradient of, and adjacent to, the INL and (2) irrigation water dissolves fertilizer, other soil amendments, and minerals in the unsaturated zone and transports the dissolved ions to the aquifer (Rattray, 2015). For example, inorganic fertilizer is primarily composed of nitrogen, potassium, and phosphorus, and chemical compounds in fertilizer containing these elements may also include $\mathrm{Ca}^{2+}, \mathrm{Na}^{+}$, and $\mathrm{SO}_{4}{ }^{2-}$. Nitrogen in fertilizer may be present in various forms, but nitrogen leached from fertilizer that infiltrates through the unsaturated zone to the aquifer will be in an oxidized form as $\mathrm{NO}_{3}^{-}$(table 2). Potassium in commercial fertilizer is often present as $\mathrm{KCl}$ (represented with sylvite in table 2), and other soil amendments, such as gypsum or agricultural lime (typically $\mathrm{CaCO}_{3}$, represented with calcite in table 2), may contribute $\mathrm{Ca}^{2+}, \mathrm{HCO}_{3}^{-}$, and $\mathrm{SO}_{4}{ }^{2-}$ to groundwater. Dissolution of minerals in the unsaturated zone, such as dolomite in the Howe area and forsterite and augite (table 2) in the Mud Lake area, may add $\mathrm{Ca}^{2+}, \mathrm{Mg}^{2+}$, and other solutes to groundwater. Groundwater influenced by irrigation in the Howe and Mud Lake areas, compared to nearby groundwater not influenced by irrigation, has elevated concentrations of $\mathrm{Ca}^{2+}, \mathrm{Mg}^{2+}, \mathrm{Na}^{+}, \mathrm{Cl}^{-}, \mathrm{NO}_{3}^{-}$, and $\mathrm{SO}_{4}{ }^{2-}$ and, in the Mud Lake area, $\mathrm{HCO}_{3}^{-}$and $\mathrm{K}^{+}$(Rattray, 2018, figs. $28 F-J$ and $28 M-O$ ).

Road salt was applied to roads at and near the INL (Idaho Transportation Department, 2018), and leachate from road salt (table 2) that infiltrates through the unsaturated zone may add $\mathrm{Na}^{+}$and $\mathrm{Cl}^{-}$to groundwater. One site in the study area, USGS 22, had large $\mathrm{Na}^{+}$and $\mathrm{Cl}^{-}$concentrations that

\footnotetext{
${ }^{9}$ The mass action equation for the monovalent-divalent cation exchange reaction shown in table 2 is in appendix 1, eq. 1-4.
}

do not seem to be associated with irrigation or discharge of wastewater. Well USGS 22 is located about 0.33 mi northeast, and generally downwind, of Idaho State Highways 20/26 (fig. 2). Precipitation seems to be the source of water at USGS 22 (Busenberg and others, 2001; Rattray, 2018). Therefore, for $\mathrm{Na}^{+}$and $\mathrm{Cl}^{-}$in groundwater at USGS 22 to originate from road salt, precipitation must dissolve road salt applied to the highway and then transport $\mathrm{Na}^{+}$and $\mathrm{Cl}^{-}$horizontally and vertically through the unsaturated zone (Nimmo and others, 2002) or precipitation must dissolve road salt blown to the vicinity of USGS 22 and then transport $\mathrm{Na}^{+}$and $\mathrm{Cl}^{-}$vertically through the unsaturated zone.

\section{Redox Reactions}

Redox reactions included oxidation of organic matter and oxidation of upwelling, anoxic geothermal water that mixed with oxidized groundwater. Redox reactions often proceed at significant rates only when mediated by bacterial catalysis (Appelo and Postma, 2005). Biochemistry investigations were beyond the scope of this report, so if the groundwater chemistry indicated that redox reactions took place the appropriate bacteria were assumed to be present.

Anoxic groundwater occurs in contaminated groundwater at the TAN Disposal well (table 6). The anoxic groundwater was due to discharge of organic compounds in wastewater at TAN and subsequent oxidation of the organic compounds. These chemical reactions are represented generically with oxidation of organic matter $\left(\mathrm{CH}_{2} \mathrm{O}\right)$, a reaction that consumes $\mathrm{O}_{2}$ and oxidizes carbon (table 2).

Anoxic groundwater was assumed to be present in geothermal groundwater at borehole INEL-1 10,300 feet based on the large iron $(1,100$ micrograms per liter $[\mu \mathrm{g} / \mathrm{L}]$; table 6) and small uranium $(0.19 \mu \mathrm{g} / \mathrm{L}$; Rattray, 2018, table 8 ) concentrations. Physical and chemical properties of groundwater at the INL that mixed with upwelling geothermal water included small $\mathrm{O}_{2}$ concentrations, large groundwater temperatures, large He concentrations, and (or) large isotope ratios of He (Rattray, 2018; tables 5 and 9). These physical and (or) chemical properties were measured in water from wells USGS 146 and USGS 27 which suggests the presence of upwelling geothermal water at these wells. Geochemical modeling of upwelling geothermal water mixing with groundwater in the Mud Lake area showed that the only redox reaction required to produce plausible models ${ }^{10}$ of the water mixture was oxidation of methane (Rattray, 2015). Oxidation of methane consumes methane $\left(\mathrm{CH}_{4}\right)$ and $\mathrm{O}_{2}$ and produces $\mathrm{CO}_{2}$ and water (table 2).

\footnotetext{
${ }^{10}$ A successful model is a model result that converges to a mathematical solution. A plausible model is a model result that meets the hydrologic, thermodynamic, kinetic, and mass-balance constraints of the model. Many successful model results are not plausible models.
} 


\section{Geochemical Modeling}

Geochemical modeling was conducted for groundwater residing in the ESRP aquifer at and south of the INL. Geochemical modeling was completed using the inverse, mass-balance modeling capability of PHREEQC (Parkhurst and Appelo, 2013). Inverse modeling attempts to identify the net chemical reactions that account for observed changes in chemistry between initial (one or more) and final (one) water compositions along a single flowline or joined flowlines (Parkhurst and Appelo, 2013, p. 7).

Recharge from the BLR is episodic and ephemeral, which creates a dynamic aquifer system in the northern, central, and western parts of the INL. Most water compositions for natural groundwater at the INL reflect conditions when the BLR was providing recharge to the ESRP aquifer at the INL. Geochemical modeling with these water compositions, therefore, will show greater recharge from the BLR than would modeling with water compositions reflecting a period of no recharge from the BLR.

Model inputs consisted of the chemical and isotopic compositions of aqueous solutions, the gas and solid (mineral) phases existing within the aquifer, and the set of chemical elements (hydrogen, oxygen, carbon, calcium, magnesium, sodium, potassium, chloride, sulfur, fluoride, nitrogen, silica, aluminum, and iron) that describe the solutions and phases. The thermodynamic conditions of water compositions (table 9), with respect to minerals (see section, "WaterRock Interaction"), place constraints on the set of plausible chemical reactions that may occur in the aquifer ${ }^{11}$ (table 2). Other model constraints included chemical constraints, which are the chemical and isotopic constituents in the system that were used in models (tables 6-8), and the uncertainty limits assigned in PHREEQC to the aqueous solutions (global uncertainty) and stable isotope ratios (isotope uncertainty). To achieve plausible model results for a few final solutions, it also was necessary to increase the uncertainty limits for fluoride or nitrate concentrations using the "balances"12 identifier in PHREEQC. These uncertainties include the uncertainties in collecting water samples, chemical analysis of the water samples, and from the spatial variability of the water chemistry (Parkhurst, 1997). The nonunique model results were the percentage contributions of initial solutions and the sets of gas and solid phase mass transfers into or out of solution that accounted for the change in chemistry between the initial and final solutions.

\footnotetext{
${ }^{11}$ For example, for a mineral to dissolve in a model simulation that mineral must be undersaturated or near equilibrium with at least one of the initial or final solutions in the model.

12 "Balance" is a uniquely specified uncertainty for a specific chemical constituent for a specific model simulation.
}

\section{Model Inputs}

Input to the geochemical models consisted of the chemical compositions of the aqueous solutions (tables 6-8) and the set of gases and solid phases involved in plausible chemical reactions in the ESRP aquifer (tables 2 and 9).

\section{Aqueous Solutions}

Aqueous solutions used in the models were the chemical and isotopic compositions of precipitation, surface water, geothermal water, and groundwater samples (tables 6-8). The global uncertainty for solutions with a charge balance ${ }^{13}$ (CB) of 5 percent or less was left as the default value in PHREEQC of 5 percent. If a solution had a CB greater than 5 percent (table 7) the global uncertainty was set to the smallest value within the range $\mathrm{CB}+1$ percent that would allow an electrically balanced solution in PHREEQC. Calculated speciation of carbon caused large electrical imbalances in very dilute, acidic solutions (precipitation; table 2), and these solutions required large global uncertainties (15-35 percent; table 10, at back of report) to achieve electrical balance in PHREEQC calculations. The redox state of the solutions, specified with pe, was left as the default value in PHREEQC of 4 . This pe value was suitable for the oxic conditions detected in most water in the study area. There were two anoxic solutions, organic waste-influenced groundwater from the TAN Disposal well and geothermal water from borehole INEL-1 10,300 feet, where the default pe value was not suitable. These solutions were assigned a pe of -5 so that speciation of constituents with PHREEQC would produce reduced species of carbon (methane) and sulfur (hydrogen sulfide).

Inorganic constituents with (1) censored concentrations $(<$, less than) were assigned model concentrations of onehalf the censored concentration with an uncertainty of \pm 100 percent (using the "balances" identifier) and (2) estimated concentrations ( $\mathrm{E}$ or $\approx$, estimated) were assigned model concentrations of the estimated concentration with an uncertainty of \pm 10 percent. A few water samples did not have a measured concentration (nd, not determined; table 6) for aluminum (14 water samples) and iron (4 water samples) and were assigned model concentrations based on concentrations in water from nearby wells or similar water types and assigned an uncertainty of \pm 10 percent. Stable isotope ratios were assigned uncertainties of \pm 1 permil for $\delta^{2} \mathrm{H}$ and \pm 0.1 permil for $\delta^{18} \mathrm{O}$ and $\delta^{13} \mathrm{C}$, estimated ( $\approx$, estimated) stable isotope ratios (for the three snow samples and the BLR below INL Diversion; table 8) were assigned the same uncertainties, and carbon stable isotope ratios for solid and gas phases

\footnotetext{
${ }^{13}$ The equation for calculating charge balance is provided in appendix 1.
} 
were assigned values of $0 \pm 1$ permil for calcite and dolomite and $-18 \pm 4$ permil for carbon dioxide (Rattray, 2018). Larger uncertainties for some stable isotope ratios, fluoride, and (or) nitrate were required in some model simulations to produce plausible model results. All larger uncertainties were noted in the "comments" column in the table of model results (table 10).

\section{Gas and Solid Phases}

The ESRP aquifer generally behaves as a closed aquifer system with respect to atmospheric gases (Schramke and others, 1996; Busenberg and others, 2001). However, areas where infiltration of surface water occurs, such as from streams, irrigation, and wastewater discharge, may transport atmospheric $\mathrm{O}_{2}$ and unsaturated zone $\mathrm{CO}_{2}$ to the aquifer. Consequently, these two gas phases were included in geochemical models that included surface water as an initial solution.

Solid phases in the aquifer system are the minerals and other solid phases described in the section, "Chemical Reactions." Solid phases included in all geochemical models were calcite, gypsum, halite, fluorite, olivine $\left(\mathrm{Fo}_{85}\right)$, plagioclase $\left(\mathrm{An}_{60}\right)$, basalt volcanic glass, calcium montmorillonite, and goethite. Pyroxene (as augite to ferroaugite) was a ubiquitous mineral in the aquifer system, but was not included in model simulations because only one of either olivine or pyroxene was required to produce plausible model results.

Other minerals or solid phases used in geochemical models were generally limited to specific geographic areas. For example, cation exchange was a plausible reaction throughout the ESRP aquifer because interbed sediment is ubiquitous throughout the aquifer (Anderson and Liszewski, 1997). However, cation exchange probably significantly influences water chemistry only in the northwestern half of the INL where thick interbedded sediments compose a large part of the aquifer (Whitehead, 1992). Dolomite, which should be present only in the ESRP in sediment derived from carbonate rocks in the mountains, was also included as a plausible reaction in the northwestern half of the INL. Minerals associated with rhyolite (plagioclase $\left[\mathrm{An}_{25}\right]$, rhyolite volcanic glass, potassium feldspar, sodium montmorillonite) were included in models near rhyolitic outcrops in the southern parts of the Lemhi Range and Beaverhead Mountains (fig. 3), the rhyolitic domes near the southern boundary of the INL, and in water influenced by upwelling geothermal water that flowed upward through rhyolite underlying the ESRP basalt aquifer. Anthropogenic inputs represented in geochemical modeling included nitrate and potassium (represented with ammonium nitrate and sylvite in table 2) in fertilizer applied to irrigated land; road salt applied to roads; and sodium, chloride, nitrate, and organic compounds (represented with halite, ammonium nitrate, and organic matter $\left[\mathrm{CH}_{2} \mathrm{O}\right]$ ) discharged in wastewater (fig. 2).

\section{Model Results}

Geochemical models were produced for $2 \mathrm{BC}$ valley groundwater samples, 1 deep groundwater sample, 29 contaminated groundwater samples, and 64 natural groundwater samples (table 10). The models were run in minimal mode, which means that the models were "reduced to the minimum number of phases that can satisfy all of the constraints within the specified uncertainty limits" (Parkhurst and Appelo, 2013, p. 89). Use of the minimal mode means that the model results do not include every possible combination of phases that could result in a successful model. However, the models produced in the minimal mode were capable of identifying the most essential physical and chemical processes influencing the geochemistry of groundwater in the study area.

Geochemical models for each final solution produced from one to tens of successful models. However, for simplicity, all model results (initial solutions, percentage of initial solutions, and mass transfer of phases) for each final solution were evaluated and one "representative model" was recorded in table 10. Representative models were selected based on numerous criteria. These criteria included:

- Flow paths between the sites for initial and final solutions were generally consistent with water table contours (fig. 5 ) and groundwater flow directions identified by Rattray (2018).

- Initial solutions were selected from the closest sites hydrologically upgradient of the site of the final solution that produced a plausible model.

- Selections regarding the initial solutions used to evolve to a final solution were generally consistent with sources of recharge and mixing of water identified by Rattray (2018).

- Dissolution or precipitation of reacting phases was consistent with the thermodynamic state of at least one of the initial or final model solutions (table 9).

- Reacting phases generally were consistent among all geochemical models throughout the study area (allowing for geographic variability of dissolution of dolomite, rhyolite minerals, and the presence of anthropogenic inputs) and generally included dissolution of basalt minerals.

- Individual phase mass transfers were on the order of micromoles per kilogram of water ( $\mu \mathrm{mol} / \mathrm{kg}$ water) (Rattray and Ginsbach, 2014; Rattray, 2015), consistent with the dilute nature of most natural groundwater (specific conductance of 277-680 microsiemens per centimeter at 25 degrees Celsius $\left[\mu \mathrm{S} / \mathrm{cm}\right.$ at $\left.25^{\circ} \mathrm{C}\right]$; Rattray, 2018, table 9) and the small dissolution rate of silicate minerals (Lasaga and others, 1994).

- Mass transfer amounts associated with incongruent dissolution of aluminosilicate phases and the concurrent precipitation of clay minerals were consistent with their reaction ratios in table 2 . 
The dominant chemical reactions simulated in the geochemical models were dissolution of plagioclase $\left(\mathrm{An}_{60}\right)$ and basalt volcanic glass and precipitation of calcite (table 10). Other minerals simulated as dissolving were calcite, dolomite, olivine $\left(\mathrm{Fo}_{85}\right)$, plagioclase $\left(\mathrm{An}_{25}\right)$, rhyolite volcanic glass, potassium feldspar, evaporite minerals (gypsum, halite, fluorite, and sylvite), and ammonium nitrate. Dissolution of dolomite was simulated in the northern parts of the INL. Carbon dioxide and dissolved oxygen were simulated as dissolving into solution if recharge of surface water was simulated. Cation exchange and dissolution of organic compounds $\left(\mathrm{CH}_{2} \mathrm{O}\right.$ in table 10$)$ were simulated under specific chemical conditions described below.

Two solid phases, clay minerals and goethite, were simulated as precipitating in the geochemical models and were reaction products (tables 2 and 10). For example, precipitation of clay minerals was represented in nearly all geochemical models and was a result of incongruent dissolution of plagioclase, volcanic glass, and (or) potassium feldspar. Precipitation of goethite typically was represented only in geochemical models if basalt volcanic glass and (or) olivine were represented as dissolving into solution. Dissolution of these minerals releases ferrous iron into solution (table 2). Ferrous iron subsequently becomes oxidized to ferric iron in the well-oxygenated ESRP aquifer, and a ferric iron oxide/ hydroxide, represented with goethite in geochemical models, precipitates from solution because ferric iron is nearly insoluble in the oxic, slightly alkaline conditions present in the ESRP aquifer (Manahan, 1991, fig. 4-4).

\section{Natural Groundwater}

\section{North INL Area}

The North INL Area consists of six wells located near TAN (figs. 1 and 7). Discussion of model simulation results for the North INL Area also includes wells USGS 126b and $\mathrm{P} \& \mathrm{~W} 2$, which are in the lower $\mathrm{BC}$ valley but are within the boundaries of the INL. Geochemical modeling indicated that groundwater in the North INL Area originated as recharge from BC, the BLR, or both streams, which showed that the North INL Area was an active area of surface water recharge (table 7).

Weathering of silicate minerals was expected to occur in the North INL Area because surface water from BC and the BLR and groundwater from the $\mathrm{BC}$ valley and the North INL Area had low silica concentrations and were very undersaturated with respect to amorphous silica (figs. 10-11) and other silicate minerals that compose the aquifer (table 9). Thermodynamic conditions favored dissolution of basalt volcanic glass over dissolution of plagioclase $\left(\mathrm{An}_{60}\right)$ because incongruent dissolution of glass releases silica into solution whereas incongruent dissolution of plagioclase $\left(\mathrm{An}_{60}\right)$ consumes silica (with calcium montmorillonite as a product in both reactions; table 2). A small amount of dissolution of rhyolite minerals was simulated for models of groundwater from wells No Name 1 and TDD 3 (table 10). ${ }^{14}$

The occurrence of evaporite minerals and dolomite in the North INL Area was consistent with the presence in this Area of alluvial and fluvial sediment that originated from carbonate rocks in the mountains and authigenic gypsum associated with lacustrine sediment (Blair, 2002; Geslin and others, 2002). The presence of gypsum in sediment in the North INL Area also may be due to the increased presence of gypsum- and anhydrite-bearing rocks in the Beaverhead Mountains (fig. 1) relative to surrounding mountains (Robertson and others, 1974). The dissolution of ammonium nitrate probably reflects nitrogen compounds in discharge of sewage at TAN (IET 1 disposal, ANP 8) and transport of soil nitrogen in surface water infiltrating to the aquifer (USGS 126b, ANP 6, PSTF Test, TDD 3).

Precipitation of calcite was probably driven by the dissolution of gypsum, dolomite, and silicate minerals. These dissolution reactions add calcium and (or) bicarbonate to groundwater and may consume $\mathrm{CO}_{2}$ (table 2), all of which increases the SIs for calcite. Saturation indices increase or decrease proportionally with the ion activity product (IAP) for a reaction (appendix 1, eq. 1-2), and the IAP for calcite is expressed as (Drever, 1997, p. 52-54):

where

$$
I A P=\frac{\left[\mathrm{Ca}^{2+}\right]\left[\mathrm{HCO}_{3}^{-}\right]^{2}}{P_{\mathrm{CO}_{2}}},
$$

$\left[\mathrm{Ca}^{2+}\right]$ is the activity ${ }^{15}$ of calcium in groundwater,

$\left[\mathrm{HCO}_{3}^{-}\right]$is the activity of bicarbonate in groundwater, and

$\left[P_{\mathrm{CO}_{2}}\right] \quad$ is the fugacity ${ }^{16}$ of carbon dioxide.

Thus, groundwater becomes more saturated with respect to calcite, and the IAP increases, when water-rock interaction causes the ratio of the product of calcium and squared bicarbonate activities ${ }^{17}$ divided by the fugacity of $\mathrm{CO}_{2}$ to increase (eq. 1).

The geochemical models of groundwater from two wells, IET 1 Disposal and No Name 1, indicated that chemical reactions or physical processes occurred that were not typical for the ESRP aquifer at the INL. The IET 1 Disposal well had a nearly anoxic $\mathrm{O}_{2}$ concentration of $0.7 \mathrm{mg} / \mathrm{L}$ (table 6 ), even though the aquifer was a well-oxidized system. This small $\mathrm{O}_{2}$ concentration resulted from the disposal of

\footnotetext{
${ }^{14}$ Models of groundwater from a well refer to the representative model shown in table 10 where that well was the final solution.

${ }^{15}$ Activity is a measure of the effective concentration of a solute (Atkins, 1986).

${ }^{16}$ Fugacity is a measure of the effective partial pressure of a gas (Atkins, 1986).

${ }^{17}$ Solute activities may be represented with solute concentrations for dilute solutions under environmental conditions (Drever, 1997).
} 
organic compounds in wastewater discharged at TAN (U.S. Department of Energy, 2011) and the subsequent oxidation of these organic compounds in the aquifer. ${ }^{18}$ This redox reaction was represented in the geochemical model for groundwater from the IET 1 Disposal well with oxidation of a small amount of organic matter $(131 \mu \mathrm{mol} / \mathrm{kg}$ of water; table 7$)$, which results in the consumption of $\mathrm{O}_{2}$ and the production of $\mathrm{CO}_{2}$ (table 2). Groundwater from No Name 1 had unusually large stable isotope ratios of water $\left(\delta^{2} \mathrm{H}=-130.4\right.$ permil, $\delta^{18} \mathrm{O}=$ -15.86 permil; table 8 ). These large stable isotope ratios were probably caused by evaporation of streamflow (Rattray, 2018) that accumulated at playa 4 (fig. 2) and subsequently infiltrated to the aquifer. The geochemical model for groundwater from well No Name 1 included evaporation. Although fractionation of the stable isotope ratios of water were not modeled, the evaporation factor was 1.27 (which indicates that 1.27 kilograms $[\mathrm{kg}]$ of initial solution evaporates to $1.00 \mathrm{~kg}$ of final solution; table 10) and the reduction in water volume of the initial solutions was 21 percent. This is a reasonable reduction in water volume from playa 4 based on estimated evaporation rates of $0.02-0.03 \mathrm{ft} / \mathrm{d}$ (Rattray, 2017) during late spring-early summer at ponds and lakes at the Camas National Wildlife Refuge (fig. 2).

\section{Northeast INL Area}

The Northeast INL Area consists of six wells located immediately downgradient of regional groundwater that was influenced by irrigation (figs. 2, 5, and 7) and geothermal water (Rattray, 2015). Geochemical modeling indicated that regional groundwater, groundwater from the $\mathrm{BC}$ valley, and surface water from the BLR were sources of recharge to the Northeast INL Area (table 10).

Phase mole transfers of silicate minerals for groundwater from the Northeast INL Area were generally smaller than for groundwater from the North INL Area and consisted primarily of dissolution of plagioclase $\left(\mathrm{An}_{60}\right)$ instead of basalt volcanic glass (table 10). Dissolution of plagioclase $\left(\mathrm{An}_{60}\right)$ may have been thermodynamically favored over dissolution of amorphous silica because (1) silica concentrations in groundwater were larger in the Northeast INL Area than the North INL Area (table 7, fig. 10) and (2) incongruent dissolution of plagioclase $\left(\mathrm{An}_{60}\right)$ removes silica from solution, whereas incongruent dissolution of basalt volcanic glass releases silica to solution (table 2). Geochemical models for groundwater from wells USGS 26 and USGS 27 included dissolution of rhyolite minerals; this was a plausible result because rhyolitic debris from the southern part of the Beaverhead Mountains probably resides in alluvial sediment in the northern part of the INL (fig. 3). The dissolution of evaporite minerals and ammonium nitrate may reflect agricultural inputs from the Mud Lake area or, for evaporite

\footnotetext{
${ }^{18}$ The relatively large amount of dissolution of halite (table 10) in the mode result for the IET1 Disposal well probably was related to discharge of $\mathrm{Na}$ and $\mathrm{Cl}$ in wastewater at TAN (Rattray, 2018).
}

minerals, may be due to solution of evaporite minerals associated with lacustrine sediment (fig. 3).

Groundwater at USGS 27 had a large $\delta^{3} \mathrm{He}$ value (870 percent; Rattray, 2018), which indicated that this water contained some geothermal water. Geochemical models that included geothermal water from borehole INEL-1 10,300 feet as an initial solution did not produce any plausible models of groundwater from USGS 27. However, vertical upwelling of geothermal water was previously modeled for regional groundwater at wells ML 27 and ML 29 (Rattray, 2015), and plausible models of groundwater from USGS 27 were produced using groundwater from these wells as initial solutions (table 10). Consequently, the geothermal water at USGS 27 seems to be from horizontal flow of regional groundwater containing geothermal water instead of vertical upwelling of geothermal water beneath USGS 27.

\section{Southeast INL Area}

The Southeast INL Area consists of 14 wells located in the southeastern part of the INL and south of the INL (fig. 7). Geochemical modeling indicated that regional groundwater was the primary source of recharge to these wells.

Silicate weathering either was not simulated or was simulated in small amounts (4-8 $\mu \mathrm{mol} / \mathrm{kg}$ water) for four groundwater sites from the Southeast INL Area (table 10). Silica concentrations in groundwater from the ESRP basalt aquifer were generally largest in regional groundwater and groundwater from the Southeast INL Area and had an upper concentration limit of about $37 \mathrm{mg} / \mathrm{L}$ (fig. 10). Larger silica concentrations (41-48 mg/L; fig. 10) were measured in groundwater from four sites (ML 17, ML 25, Reno Ranch, USGS 146), ${ }^{19}$ and the larger concentrations at these sites probably were related to dissolution of rhyolite minerals (Rattray, 2015, 2018). The upper concentration limit for silica in the ESRP aquifer of about $37 \mathrm{mg} / \mathrm{L}$ was well below the theoretical upper concentration limit of $120 \mathrm{mg} / \mathrm{L}$ for amorphous silica, indicating that some mechanism other than dissolution of amorphous silica (or noncrystalline basalt volcanic glass) may be controlling the upper concentration limit of silica in the aquifer (Knobel and others, 1997). Possible reasons for this relatively small upper concentration limit may be that (1) silicate minerals in the aquifer (plagioclase $\left[\mathrm{An}_{60}\right]$, forsterite $\left[\mathrm{Fo}_{85}\right]$, augite, basalt volcanic glass) were less soluble than the theoretical thermodynamic solubility, at $25^{\circ} \mathrm{C}$, of the representative silicate minerals listed in table 9 (albite, anorthite, clinoenstatite, diopside, forsterite, amorphous silica), (2) solution of silicate minerals was impeded by kinetic controls on solubility, and (or) (3) the concentration of silica was in equilibrium with the ESRP aquifer and this equilibrium was controlled by the rates and mechanisms of the irreversible weathering reactions of aluminosilicate minerals (Knobel and others, 1997).

\footnotetext{
${ }^{19}$ Sites ML 17 and ML 25 are from Rattray (2015; 2018, table 13).
} 
The geochemical model for groundwater from the Houghland well included dissolution of rhyolite minerals and fluorite, and the geochemical model for groundwater from USGS 14 included these minerals plus halite and ammonium nitrate. Dissolution of rhyolite minerals and fluorite was a plausible result for groundwater from these wells because the Big Southern Butte was a nearby source of rhyolite (fig. 3), and dissolution of halite and ammonium nitrate for groundwater from USGS 14 may reflect $\mathrm{Na}, \mathrm{Cl}$, and $\mathrm{NO}_{3}$ in wastewater or sewage discharged at the INTEC and (or) Central Facilities Area (CFA) (Rattray, 2018) or the influence of irrigation in the Atomic City area (fig. 2).

\section{Central INL Area}

The Central INL Area consists of eight wells located between playa 3 and Big Southern Butte (figs. 2, 3, and 7). Geochemical modeling indicated that infiltration of water from the BLR was the primary source of recharge to these wells, with lesser amounts of recharge from $\mathrm{BC}$, groundwater from the LLR and BC valleys, upward moving deep groundwater, and wastewater discharged at INTEC and (or) CFA.

The SIs for amorphous silica and the concentrations of silica $(21.8-25.8 \mathrm{mg} / \mathrm{L})$ in groundwater from the Central INL Area were both smaller than for regional groundwater or groundwater from the Southeast INL Area (fig. 10), indicating that silica probably was undersaturated with respect to the equilibrium state of silica in the ESRP aquifer. Thus, dissolution of volcanic glass, which releases silica to solution, was the primary silicate reaction simulated for this Area (table 10). Dissolution of plagioclase $\left(\mathrm{An}_{60}\right)$, however, was the silicate reaction for the geochemical model of groundwater from USGS 103. Conditions for the dissolution of plagioclase $\left(\mathrm{An}_{60}\right)$ at USGS 103 were provided by groundwater from the Southeast INL Area with larger silica concentrations, represented by USGS 107 (table 10), as a source of water to USGS 103. The geochemical model for groundwater from USGS 18 included deep groundwater from USGS 7 as a source of water and dissolution of potassium feldspar. The large helium concentration $\left(\left[28.8 \mathrm{~cm}^{3} \times 10^{-8}\right.\right.$ at standard temperature and pressure ( 0 degrees Celsius and 1 atmosphere pressure) per gram (STP/g)], Rattray, 2018, fig. 28E) and warm water temperature $\left(15.6^{\circ} \mathrm{C}\right.$, table 6$)$ at USGS 18 supports the presence of geothermal water at USGS 18, and upwelling geothermal water was a source of water at USGS 7 (deep groundwater in table 10). Dissolution of potassium feldspar likely occurred as upwelling geothermal water traveled through rhyolite underlying the ESRP basalt aquifer (Rattray, 2015).

\section{Northwest INL Area}

The Northwest INL Area consists of 18 wells located northwest of the BLR (fig. 7), although geochemical modeling was not done for USGS 23 because water from this well was used to represent groundwater from the Lost River Range. Geochemical modeling indicated that the BLR and groundwater from the LLR valley were the primary sources of recharge to these wells. Other sources of recharge included the LLR, precipitation, groundwater from the Lost River Range, wastewater discharged at the NRF, and geothermal water.

The Northwest INL Area is similar to the North INL Area; it was an active area of surface-water recharge and the aquifer matrix included sediment derived from the mountains (fig. 3). An important difference, however, was that most groundwater recharge to the Northwest INL Area was influenced by irrigation in the LLR valley (fig. 2) (represented by the Ruby Farms [RF], Harrell, and Nicholson wells in table 10), which led to larger concentrations of most major ions in the Northwest INL Area relative to the North INL Area (table 7).

The simulated dissolution of evaporite minerals (table 10) probably represented dissolution of these minerals in sediment derived from the mountains, evaporite deposits associated with lacustrine sediment (fig. 3), or soil amendments applied to irrigated lands in the LLR valley. The dissolution of large amounts of carbon dioxide probably represented carbon dioxide from the soil zone as water from streams, precipitation, irrigation, and wastewater discharge infiltrated downward from the land surface to the aquifer.

Geochemical models of groundwater from several wells were unusual. For example, groundwater from NRF 7, using 1996 major ion data (table 7), was modeled as consisting entirely of water from the BLR (table 10). This normally would indicate that groundwater at NRF 7 consists of young water. However, low-level measurements of tritium activity in groundwater from NRF 7 are usually small $(<4$ picocuries per liter $[\mathrm{pCi} / \mathrm{L}]$ ) and indicate that groundwater at NRF 7 is old groundwater [following the "qualitative" age convention based on tritium activities described in Rattray (2018, p. 40)], although infrequent large tritium activities at NRF 7 appear to be associated with flow in the BLR (appendix 2). Groundwater at NRF 7 is consistently dilute, with specific conductance ranging from 202 to $268 \mu \mathrm{S} / \mathrm{cm}$ at $25^{\circ} \mathrm{C}$ from 1991 through 2017 (U.S. Geological Survey, 2017), which supports a recharge source from the BLR. Therefore, groundwater at NRF 7 probably represents old recharge from the BLR, which indicates that the permeability of the basalt aquifer near NRF 7 is small and that groundwater moves slowly in this area.

Groundwater from INEL-1 WS had large concentrations of ions due to irrigation in the LLR valley (Rattray, 2018). Large ion concentrations in groundwater from the Nicholson well, in the middle part of the LLR valley, show that this water was greatly influenced by irrigation (Swanson and others, 2002), and it was necessary to use groundwater from this well as an initial solution to produce plausible geochemical models for groundwater from INEL-1 WS (table 10). Although groundwater from the Nicholson well was not actually a source of water at INEL-1 WS because it is so far upgradient, it may be representative of groundwater from the lower LLR valley that was influenced by irrigation to a greater degree than groundwater from the Harrell or Ruby Farms wells (table 7). 
Groundwater from USGS 22 was modeled entirely with precipitation as the initial solution. Chemical reactions included dissolution of calcite, a large amount of halite dissolution, reverse cation exchange, and oxidation of organic matter. Dissolution of calcite should occur because calcite was undersaturated in precipitation (Craters of the Moon; table 9). Well USGS 22 is located about one-third of a mile northeast, and downwind, of Idaho State Highway 20/26 (figs. 2 and 7), so deposition, solution, and infiltration of road salt and hydrocarbons in vehicle exhaust may account for the dissolution of a large amount of halite and oxidation of organic matter. The reverse ion exchange may be explained by sodium dissolved from road salt replacing calcium on cation exchange sites in either the unsaturated or saturated zone.

Groundwater from USGS 146 was modeled with upwelling geothermal water as an initial solution and dissolution of potassium feldspar. The large water temperature of $21.4{ }^{\circ} \mathrm{C}$ (table 6) in groundwater from USGS 146 supports a geothermal water input, and dissolution of potassium feldspar is consistent with dissolution of rhyolite as geothermal water moves upward through the rhyolite rocks underlying the basalt ESRP aquifer (Rattray, 2015).

\section{Southwest INL Area}

The Southwest INL Area consists of 13 wells located in the southwest corner, and southwest, of the INL (fig. 7). Geochemical modeling indicated that most recharge was from the BLR, with smaller amounts of recharge from the BLR and LLR valleys, precipitation, wastewater discharged at RWMC, and groundwater from the Lost River Range.

Silica concentrations and the undersaturated state of groundwater, with respect to amorphous silica, were similar between the North and Southwest INL Areas (figs. 10-11). Like the North INL Area, therefore, the thermodynamic conditions of groundwater in the Southwest INL Area favored dissolution of basalt volcanic glass over dissolution of plagioclase $\left(A n_{60}\right)$. The BLR was the primary source of recharge at wells Highway 3 and Middle 2051, and calcite was simulated as dissolving in groundwater at both wells. Dissolution of evaporite minerals and ammonium nitrate (table 10) may be from agricultural soil amendments associated with irrigation in the BLR valley and (or) wastewater discharged at the RWMC (fig. 2). Carbon dioxide and oxygen were transported to the aquifer from the unsaturated zone and land surface, respectively, as recharge from the BLR, irrigation water, precipitation, or wastewater infiltrated downward from the land surface to the aquifer.

\section{Contaminated Groundwater}

Geochemical models were generated for contaminated groundwater at or downgradient of INL site facilities (table 10). The chemical composition of wastewater discharged at site facilities was needed as an initial solution in these models and was represented at each site facility with contaminated groundwater with the largest concentrations of $\mathrm{Na}, \mathrm{Cl}$, and (or) $\mathrm{SO}_{4}$ (table 7), the dominant inorganic constituents in wastewater. Thus, contaminated groundwater representing wastewater discharge included groundwater from the TAN Disposal well at TAN, NRF 6 at the NRF, USGS 65 at the ATRC, USGS 113 at the INTEC, and USGS 88 at the RWMC.

Chemical reactions in contaminated groundwater and adjacent natural groundwater were similar (table 10). There were, however, two important differences in chemical reactions for contaminated groundwater, for wells close to wastewater discharge locations, compared to adjacent natural groundwater. These differences were reverse cation exchange and large phase mole transfer amounts of calcite and plagioclase $\left(\mathrm{An}_{60}\right)$.

In dilute $\mathrm{Ca}-\mathrm{HCO}_{3}$ type groundwater, such as at the INL, cation exchange should consist of $\mathrm{Ca}$ exchanging for $\mathrm{Na}$ on exchange sites (Chapelle and Knobel, 1983; Drever, 1997). However, geochemical modeling indicated that reverse cation exchange (Swanson and others, 2003), consisting of $\mathrm{Na}$ exchanging for $\mathrm{Ca}$ on exchange sites, took place in contaminated groundwater near wastewater discharge sites at TAN, INTEC, and CFA (table 10). Reverse cation exchange occurred because large amounts of $\mathrm{Na}$ was discharged in wastewater at these site facilities (Bartholomay and others, 1997), and reverse cation exchange significantly retarded the movement of wastewater-derived $\mathrm{Na}$ in the aquifer.

Large phase mole transfer amounts of precipitation of calcite and dissolution of plagioclase $\left(\mathrm{An}_{60}\right)$ were modeled for groundwater from NRF $13,{ }^{20}$ USGS 120, and TDD 1 (table 10). These large phase mole transfers were caused by (1) initial solutions with large Ca concentrations (table 7), (2) certain chemical conditions in final solutions, such as the small partial pressure of $\mathrm{CO}_{2}$ in groundwater from NRF 13, and (or) (3) simulated chemical reactions, such as the release of $\mathrm{Ca}$ to solution through reverse cation exchange in the model for TDD 1. The geochemical models balanced $\mathrm{Ca}$ and $\mathrm{HCO}_{3}$ concentrations in model final solutions mostly through precipitation of calcite and dissolution of plagioclase $\left(\mathrm{An}_{60}\right)$ (table 2).

The percentage of wastewater discharged at INTEC residing in contaminated groundwater south of INTEC was estimated from geochemical model results (table 10). This required an estimate of the percentage of wastewater residing in groundwater most influenced by wastewater discharge, and this percentage was estimated from chloride concentrations. Chloride concentrations were used instead of other chemical constituents because (1) large, relatively uniform mean annual amounts of chloride were discharged in wastewater at INTEC, and (2) chloride behaves conservatively in the ESRP aquifer.

The annual mean ( \pm standard deviation) chloride concentration in wastewater discharged at the INTEC infiltration ponds from 1987 to 1996 was $267 \pm 16 \mathrm{mg} / \mathrm{L}$

\footnotetext{
${ }^{20}$ The large charge balance error ( \pm 18.8 percent), and a silica concentration that was estimated, for groundwater from NRF 13 produced a large uncertainty in the model results for this groundwater.
} 
(table 3). Chloride concentrations discharged in wastewater at CFA were similarly large from 1987 to 1990 , very large in 1991, and much smaller from 1992 to 1996 . However, the annual mean discharge of wastewater at CFA $\left(1.2 \times 10^{8}\right.$ liters [L]; table 3) was more than one order of magnitude smaller than the annual mean discharge of wastewater at INTEC $\left(2.1 \times 10^{9} \mathrm{~L}\right)$. Consequently, wastewater discharged at CFA contributed less than 10 percent of the chloride in groundwater at and downgradient of CFA. Additionally, because water samples from wells at and downgradient of CFA were collected during 1995-96, after several years of wastewater discharge from CFA with small chloride concentrations, wastewater discharged at CFA probably contributed much less than 10 percent of the chloride in groundwater at and downgradient of CFA. Thus, chloride contributions from CFA were not considered in calculations of the percentage of wastewater discharged at INTEC that resided in contaminated groundwater south of INTEC.

The chloride concentration in groundwater from USGS $113,218 \mathrm{mg} / \mathrm{L}$, was the largest chloride concentration in contaminated groundwater south of INTEC (table 7). Wastewater discharged from INTEC was estimated to comprise about $81 \pm 12$ percent of groundwater at USGS 113 (table 4; see appendix 1 for calculations of percentage of wastewater at USGS 113 and uncertainty). The percentage of wastewater discharged from INTEC in contaminated groundwater at downgradient wells was estimated from the percentage of contaminated groundwater from USGS 113 in the initial solutions for these wells (table 4). ${ }^{21}$

Wastewater-contaminated groundwater flowed south from the INTEC infiltration ponds in a narrow plume (fig. 14A). Groundwater at USGS 112 and USGS 113, about $0.7-0.8$ mi south of the INTEC infiltration ponds, contained about $60-80$ percent wastewater, and groundwater at and just south of the CFA, about 2.5 mi south of the INTEC infiltration ponds, probably contained about 10-40 percent wastewater. Groundwater more than 1 mi south of the CFA probably contained less than 10 percent wastewater, and groundwater south of the southern INL boundary, about 8 mi south of the INTEC infiltration ponds, probably contained less than 5 percent wastewater. Groundwater from USGS 14, about 15.5 mi south of the INTEC infiltration ponds, was estimated to contain about 1.4 percent wastewater (table 4$).{ }^{22}$

\footnotetext{
${ }^{21}$ For example, initial solutions for USGS 36 were 69, 22, and 8 percent water from Fire Station 2, USGS 57, and the BLR at INL Diversion (table 10), respectively. Of these initial solutions, only USGS 57 contained, or had initial solutions that contained, groundwater from USGS 113. Initial solutions for USGS 57 were 49, 34, and 17 percent water from USGS 113, the BLR at INL Diversion, and Fire Station 2. Neither the BLR at INL Diversion nor Fire Station 2 have USGS 113 as an initial solution, so no additional extrapolation was necessary to account for groundwater from USGS 113 in groundwater at USGS 36. The percentage of groundwater from USGS 113 at USGS 36 equaled the fraction of groundwater from USGS 57 at USGS 36 (0.22) multiplied by the percentage of groundwater from USGS 113 at USGS 57 (49 percent) and was 10.8 percent. This process was repeated for all other contaminated groundwater south of INTEC (table 4).
}

${ }^{22}$ Average linear groundwater velocities south of INTEC were estimated
The percentage of wastewater discharged at NRF residing in contaminated groundwater at and adjacent to NRF (table 4) was estimated in a similar manner as for INTEC. The annual mean ( \pm standard deviation) chloride concentration in wastewater discharged from the NRF industrial waste ditch from 1987 to 1996 was $205 \pm 60 \mathrm{mg} / \mathrm{L}$ (table 3), the largest chloride concentration in contaminated groundwater at NRF was $240 \mathrm{mg} / \mathrm{L}$ from NRF 6 (table 7), and the percentage of wastewater discharged from the ditch that resided in groundwater at NRF 6 was $121 \pm 37$ percent (table 4). The percentage of wastewater in groundwater at NRF 6 in this calculation exceeds 100 percent and may be due to the variable concentrations of chloride in the wastewater (table 3 ).

Groundwater at NRF 6 seemed to be entirely composed of wastewater, which comprised about 36 percent of groundwater at NRF 13; these wells are about $0.05 \mathrm{mi}$ south and 0.15 mi northeast of the industrial waste ditch (fig. 14B), respectively. Wastewater-contaminated groundwater seemed to flow in a southeasterly direction toward NRF 11 and NRF 12 , and then southwesterly towards NRF 9 . Groundwater at NRF 9, about 0.6 mi south of the ditch, was composed of about 2 percent wastewater. The short distance that wastewater discharged at NRF seems to have traveled, compared to the long distance that wastewater discharged at INTEC traveled, likely was due to the much smaller volume of wastewater discharged at NRF, compared to the volume of wastewater discharged at INTEC (table 3). This allowed contaminants in wastewater discharged at NRF to be diluted to small concentrations over a short distance.

\section{Hydrologic Interpretation of Model Results}

Geochemical modeling results were used to make interpretations about sources of recharge, mixing of water, and groundwater flow directions at the INL. The sources of recharge were extrapolated, and mixing of water was calculated, from the initial solutions for groundwater sites at and south of the INL. Groundwater flow directions were estimated from the spatial distribution of groundwater sources of recharge and mixing lines.

The initial and final solutions in geochemical models should be along a flowline; consequently, apparent flowlines for geochemical modeling were derived from

\footnotetext{
to range from 4 to $20 \mathrm{ft} / \mathrm{d}$ (Ackerman and others, 2006). Using the minimum estimated velocity, wastewater would travel from the INTEC infiltration ponds to CFA in about 9 years, within the period of waste discharge represented in table 3. However, groundwater south of CFA may include wastewater discharged from INTEC prior to 1987. The annual mean chloride concentration in wastewater discharged at INTEC during $1971-86$ was $187 \pm 57 \mathrm{mg} / \mathrm{L}$, or 70 percent of the annual mean concentration discharged during 1987-96 (Orr and Cecil, 1991, and references therein). Therefore, the estimated percentage of wastewater discharged from INTEC in groundwater south of CFA (table 4; fig. 14A) may be slightly underestimated.
} 
Table 3. Mean annual concentration of chloride in wastewater discharged at Idaho Nuclear Technology and Engineering Center, Naval Reactors Facility, and Central Facilities Area, Idaho National Laboratory and vicinity, eastern Idaho.

[Data from Litteer (1988); Litteer and Reagan (1989); Litteer and Peterson (1990); Litteer and others (1991, 1992); Randall and Sims (1993); Sims and Taylor (1994); and French and others (1995, 1996, 1997). Abbreviations: CFA, Central Facilities Area; INTEC, Idaho Nuclear Technology and Engineering Center; L, liter; mg/L, milligram per liter; NRF, Naval Reactors Facility; SD, standard deviation]

\begin{tabular}{|c|c|c|c|c|c|c|}
\hline \multirow{2}{*}{ Year } & \multicolumn{2}{|c|}{$\begin{array}{l}\text { INTEC injection well and } \\
\text { infiltration ponds }\end{array}$} & \multicolumn{2}{|c|}{$\begin{array}{l}\text { NRF industrial } \\
\text { waste ditch }\end{array}$} & \multicolumn{2}{|c|}{$\begin{array}{l}\text { CFA sewage } \\
\text { plant }\end{array}$} \\
\hline & $\begin{array}{l}\text { Discharge } \\
\text { (L) }\end{array}$ & $\begin{array}{l}\text { Chloride } \\
\text { (mg/L) }\end{array}$ & $\begin{array}{l}\text { Discharge } \\
\text { (L) }\end{array}$ & $\begin{array}{l}\text { Chloride } \\
\text { (mg/L) }\end{array}$ & $\begin{array}{l}\text { Discharge } \\
\text { (L) }\end{array}$ & $\begin{array}{c}\text { Chloride } \\
\text { (mg/L) }\end{array}$ \\
\hline 1987 & $2.27 \mathrm{E}+9$ & 239 & $1.33 \mathrm{E}+8$ & 292 & $9.45 \mathrm{E}+7$ & 219 \\
\hline 1988 & $2.14 \mathrm{E}+9$ & 268 & $6.14 \mathrm{E}+7$ & 127 & $6.53 \mathrm{E}+7$ & 258 \\
\hline 1989 & $1.66 \mathrm{E}+9$ & 279 & $2.28 \mathrm{E}+8$ & 169 & $1.19 \mathrm{E}+8$ & 551 \\
\hline 1991 & $2.11 \mathrm{E}+9$ & 261 & $4.57 \mathrm{E}+8$ & 229 & $1.75 \mathrm{E}+8$ & 2,579 \\
\hline 1992 & $2.27 \mathrm{E}+9$ & 240 & $6.47 \mathrm{E}+8$ & 239 & $2.30 \mathrm{E}+8$ & 73 \\
\hline 1993 & $2.52 \mathrm{E}+9$ & 282 & $6.48 \mathrm{E}+8$ & 153 & $1.72 \mathrm{E}+8$ & 86 \\
\hline 1994 & $1.86 \mathrm{E}+9$ & 284 & $4.64 \mathrm{E}+8$ & 206 & $1.56 \mathrm{E}+8$ & 51 \\
\hline 1995 & $1.75 \mathrm{E}+9$ & 270 & $2.93 \mathrm{E}+8$ & 301 & $9.64 \mathrm{E}+6$ & 0 \\
\hline 1996 & $2.22 \mathrm{E}+9$ & 281 & $2.37 \mathrm{E}+8$ & 195 & $1.00 \mathrm{E}+7$ & 58 \\
\hline
\end{tabular}

Table 4. Percentage of wastewater discharged from the Naval Reactors Facility industrial waste ditch or the Idaho Nuclear Technology and Engineering Center infiltration ponds in groundwater at downgradient sites, 1995-96 groundwater chemistry conditions, Idaho National Laboratory and vicinity, eastern Idaho.

[Location of sites shown in figure 14. All values are percentages. Abbreviations: INTEC, Idaho Nuclear Technology and Engineering Center; NRF, Naval Reactors Facility; -, empty cell]

\begin{tabular}{|c|c|c|c|c|c|}
\hline $\begin{array}{c}\text { Site } \\
\text { name }\end{array}$ & $\begin{array}{l}\text { Groundwater from } \\
\text { NRF } 6 \text { in initial solu- } \\
\text { tions }\end{array}$ & $\begin{array}{l}\text { Amount of wastewater dis- } \\
\text { charged from the NRF Industrial } \\
\text { Waste Ditch in groundwater } \\
( \pm 36.8-37.4 \text { percent })\end{array}$ & $\begin{array}{c}\text { Site } \\
\text { name }\end{array}$ & $\begin{array}{l}\text { Groundwater from } \\
\text { USGS } 113 \text { in initial } \\
\text { solutions }\end{array}$ & $\begin{array}{l}\text { Amount of wastewater } \\
\text { discharged from the INTEC } \\
\text { infiltration ponds in ground- } \\
\text { water ( } \pm 12.0-12.6 \text { percent) }\end{array}$ \\
\hline${ }^{1} \mathrm{NRF} 6$ & 100 & 121 & ${ }^{1}$ USGS 113 & 100 & 81 \\
\hline NRF 13 & 30 & 36 & USGS 112 & 74 & 60 \\
\hline NRF 12 & 9 & 11 & CFA 2 & 52.7 & 43 \\
\hline NRF 2 & trace & trace & CFA1 & 30.4 & 25 \\
\hline- & - & - & USGS 85 & 19.3 & 16 \\
\hline- & - & - & USGS 115 & 11.8 & 9.6 \\
\hline- & - & - & USGS 36 & 10.8 & 8.7 \\
\hline- & - & - & USGS 20 & 5.9 & 4.8 \\
\hline- & - & - & USGS 14 & 1.7 & 1.4 \\
\hline- & - & - & USGS 105 & 1.6 & 1.3 \\
\hline
\end{tabular}

\footnotetext{
${ }^{1}$ See appendix 1 for calculations of uncertainty and the percentage of wastewater in groundwater at NRF 6 and USGS 113.
} 


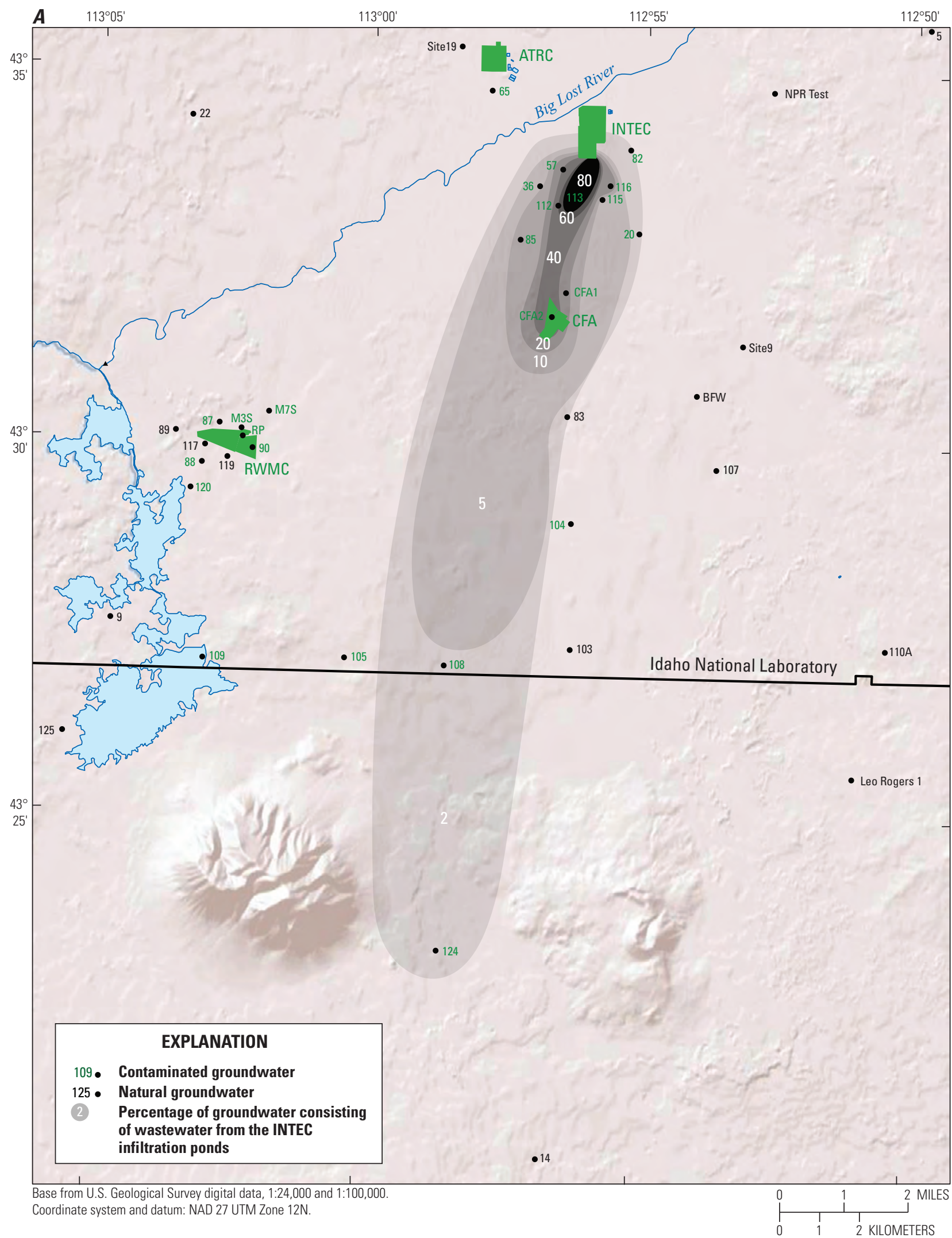

Figure 14. Areas indicating percentage of wastewater discharged from selected site facilities, Idaho National Laboratory and vicinity, eastern Idaho. Contours were hand drawn. $(A)$ Percentage of wastewater from the Idaho Nuclear Technology and Engineering Center (INTEC) infiltration ponds in contaminated groundwater south of INTEC (groundwater represents 1995-96 conditions except for 1991 conditions at wells USGS 20, USGS 57, and USGS 85). (B) Percentage of wastewater from the Naval Reactors Facility industrial waste ditch in contaminated groundwater adjacent to or downgradient of the ditch (groundwater represents 1995-96 conditions except for 1989 conditions at NRF 2). 


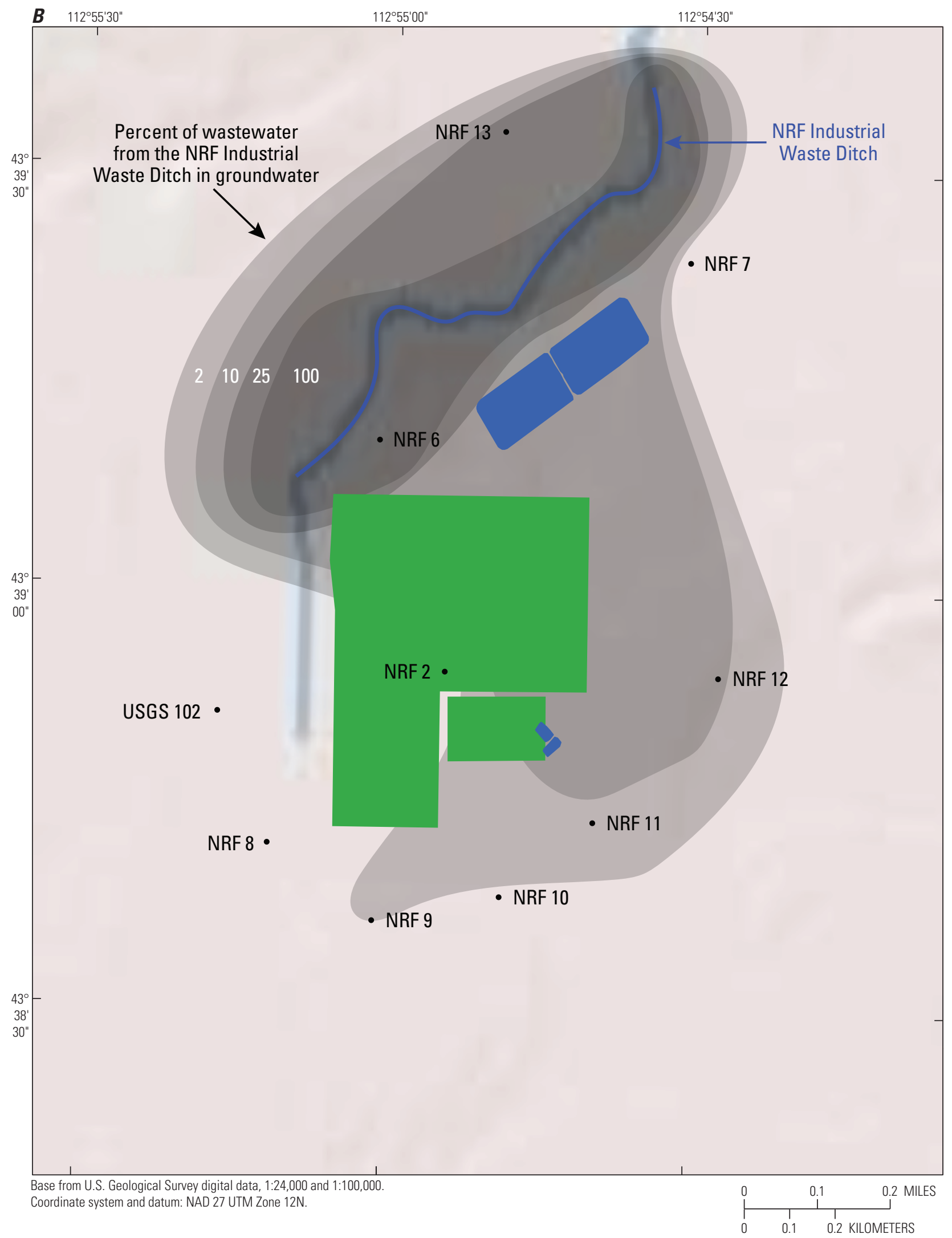

Figure 14.-Continued 
prior information. As described above, however, modeling hydrologic processes with $\mathrm{Sr}$ and $\mathrm{U}$ isotopes and major ions involves different geochemical and geologic processes. Thus, where results are consistent for the two model types, confidence is improved in results from both types of models. However, where results are inconsistent between models, this suggests that one or both models may incorrectly represent the hydrologic processes.

\section{Sources of Recharge}

Sources of recharge were identified throughout the study area from geochemical modeling results. The recharge sources identified were the primary groundwater source of recharge, recharge of surface water from the BLR, infiltration of precipitation, and upwelling of geothermal water (table 11, at back of report; fig. $15 \mathrm{~A}-\mathrm{C}$ ). The spatial distribution of the sources of recharge determined from geochemical modeling was then compared to the spatial distribution of (1) sources of recharge determined largely from strontium and uranium isotope ratios (Rattray, 2018) and (2) source water areas determined from backward particle tracking (Fisher and others, 2012).

The primary ${ }^{23}$ groundwater source of recharge at any location in the study area was either groundwater from one of the tributary valleys or regional groundwater (fig. 15A). Because the LLR does not flow onto the INL, and because most flow in $\mathrm{BC}$ has been diverted north of the INL since 1969 , these surface water sources of recharge, represented as initial solutions in table 10 , were added to the groundwater sources of recharge for their respective valleys in table 11 and figure $15 \mathrm{~A}$. Initial solutions of surface water from Mud Lake represented irrigation with surface water in the Mud Lake area. Consequently, recharge from Mud Lake was included with recharge of regional groundwater. Groundwater at USGS 23 seems to originate from the Lost River Range (Busenberg and others, 2001; Rattray, 2018); therefore, when USGS 23 was an initial solution it represented recharge of groundwater from the Lost River Range. Wastewater discharged from INL site facilities also was tracked as a source of recharge ${ }^{24}$ (groundwater containing recharge of wastewater, table 11) but was disregarded for figure $15 \mathrm{~A}$ because the original source of the water was not known.

The BLR is an important source of recharge to the ESRP aquifer at the INL because the BLR channel, sinks, playas, and spreading areas extend across a large area of the INL. However, flow from the BLR at the INL varies from no flow

\footnotetext{
23 "Primary" indicates that most groundwater at a specified well was from the indicated source of recharge; however, other groundwater sources of recharge also may contribute to groundwater at the well.

${ }^{24}$ Wastewater discharged from TAN, NRF, INTEC, and RWMC was represented with groundwater with the largest amount of contamination from wastewater from each facility, and therefore was represented with groundwater from the TAN Disposal well and wells NRF 6, USGS 113, and USGS 88, respectively.
}

during dry climate periods to several hundred cubic feet per second during wet climate periods (fig. 4). This flow regime produces an episodic nature of recharge at the INL, with periods of large and small amounts of recharge during wet and dry climate periods, respectively. The period when most of the chemistry data for natural groundwater was collected, 1995-96, was the beginning of a wet climate period. Thus, the areal distribution of recharge from the BLR shown in figure $15 \mathrm{~B}$ represents a period of increasing recharge from the BLR.

Both precipitation and geothermal water are thought to provide only small amounts of recharge to the ERSP aquifer at the INL (Ackerman and others, 2006). However, geochemical modeling indicated that some recharge from both these sources occurred at the INL (fig. 15C).

Sources of recharge were represented by the modeled initial solutions to a specific well (table 11). However, because initial solutions usually represented groundwater from the ESRP aquifer, and not direct sources of recharge, it was necessary to extrapolate backward through initial solutions for upgradient wells to identify the actual source(s) of recharge. The initial solutions for well ANP 9 provide an example calculation showing how initial solutions were extrapolated backward to actual sources of recharge. The initial solutions for ANP 9 were 69 percent groundwater from USGS 26, 13 percent groundwater from ANP 8, 12 percent surface water from the BLR below lower Lincoln Blvd Br, and 5 percent groundwater from Reno Ranch (table 11). The initial solutions for USGS 26 and ANP 8 represent natural groundwater, whereas the initial solutions for the BLR below lower Lincoln $\mathrm{Blvd} \mathrm{Br}$ and Reno Ranch represent actual sources of recharge from the BLR and regional groundwater, respectively. Starting the extrapolation process, the initial solutions for USGS 26 were 53 percent P\&W 2, 24 percent IET 1 Disposal, 15 percent Reno Ranch, and 8 percent ML 34, and the initial solutions for ANP 8 were 60 percent BC and 40 percent BLR. Actual sources of recharge from this extrapolation step were regional groundwater (Reno Ranch and ML 34), the BLR, BC, and $\mathrm{BC}$ valley groundwater (P\&W 2). Extrapolation continues for IET 1 Disposal which had initial solutions of 72 percent BLR and 28 percent BC. Both the BLR and BC represent actual sources of recharge, and no additional extrapolation was necessary. After extrapolation, the percentage of sources of recharge to ANP 9 were 37 percent BC valley groundwater, 29 percent water from the BLR, 21 percent regional groundwater, ${ }^{25}$ and 12 percent water from $\mathrm{BC}$. Recharge from $\mathrm{BC}$ was added to recharge of groundwater from the $\mathrm{BC}$ valley, so recharge of groundwater from the BC valley is shown as 49 percent in table 11 .

\footnotetext{
${ }^{25}$ The percentage of regional groundwater that was a source of recharge to ANP 9 was calculated as: $\left[\left(1.0_{(\mathrm{ANP9})}\right) *\left(5 \%_{(\mathrm{RR})}\right)\right]+\left[\left(1.0_{(\mathrm{ANP9})}\right) *\left(0.69_{(\mathrm{USGS} 26)}\right) *(15\right.$ $\left.\left.\%_{(\mathrm{RR})}\right)\right]+\left[\left(1.0_{(\mathrm{ANP})}\right) *\left(0.69_{(\mathrm{USGS} 26)}\right) *\left(8 \%_{(\mathrm{ML} 34)}\right)\right]=21$ percent.
} 


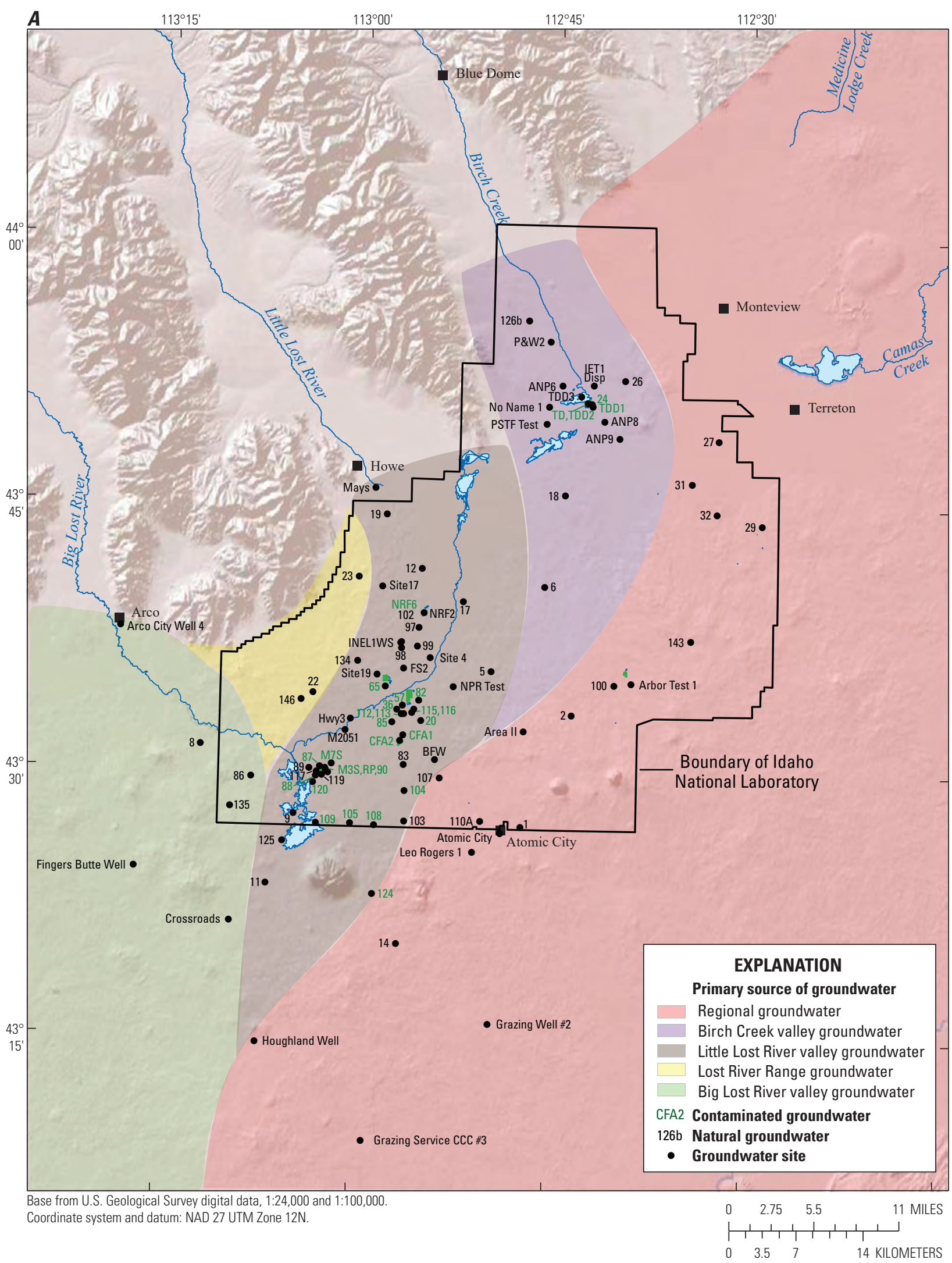

Figure 15. Sources of recharge based on geochemical modeling, Idaho National Laboratory and vicinity, eastern Idaho. $(A)$ Primary groundwater sources of recharge; $(B)$ recharge of surface water from the Big Lost River; and $(C)$ areas where infiltration of precipitation occurred and areas where groundwater contains some geothermal water. 


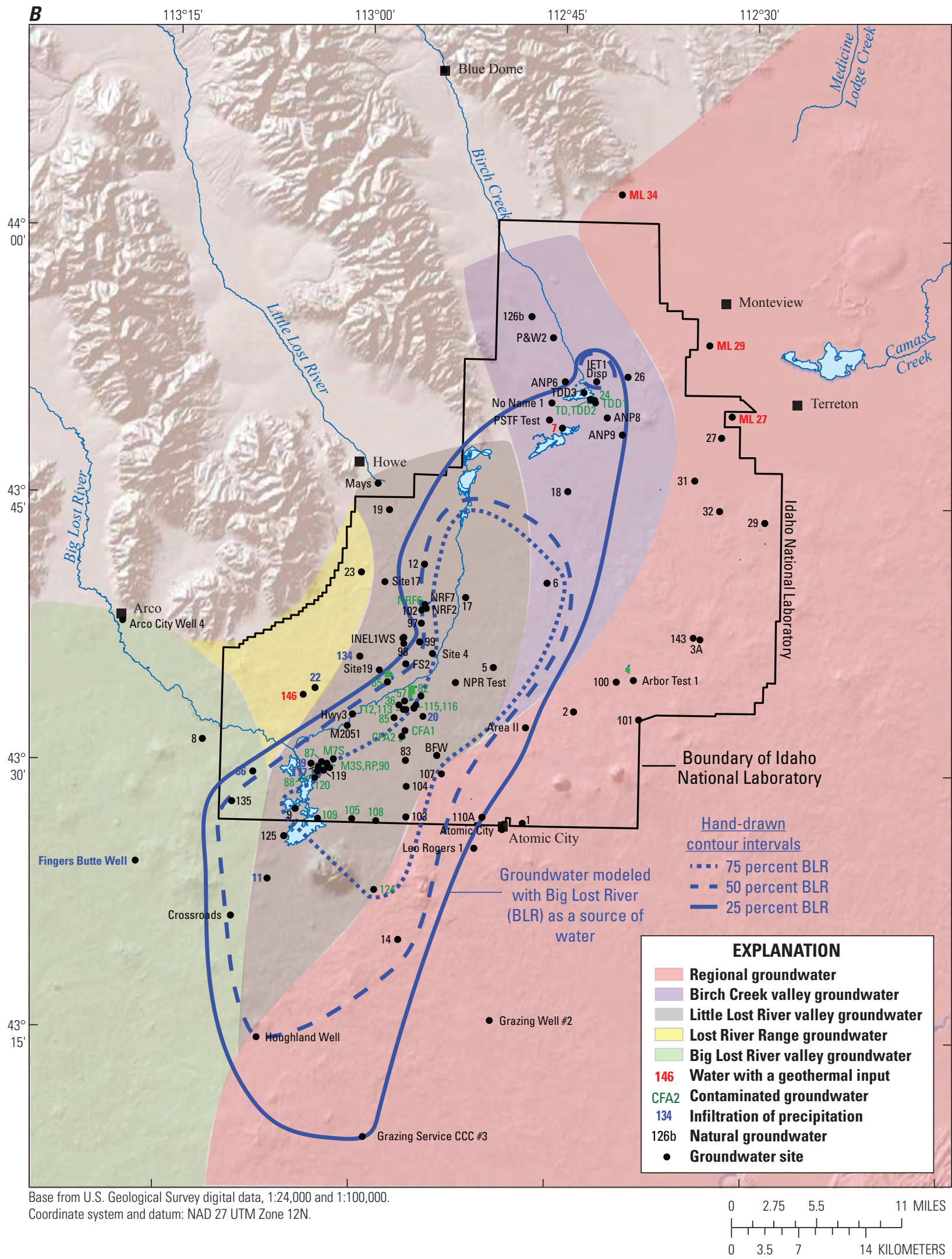

Figure 15.-Continued 


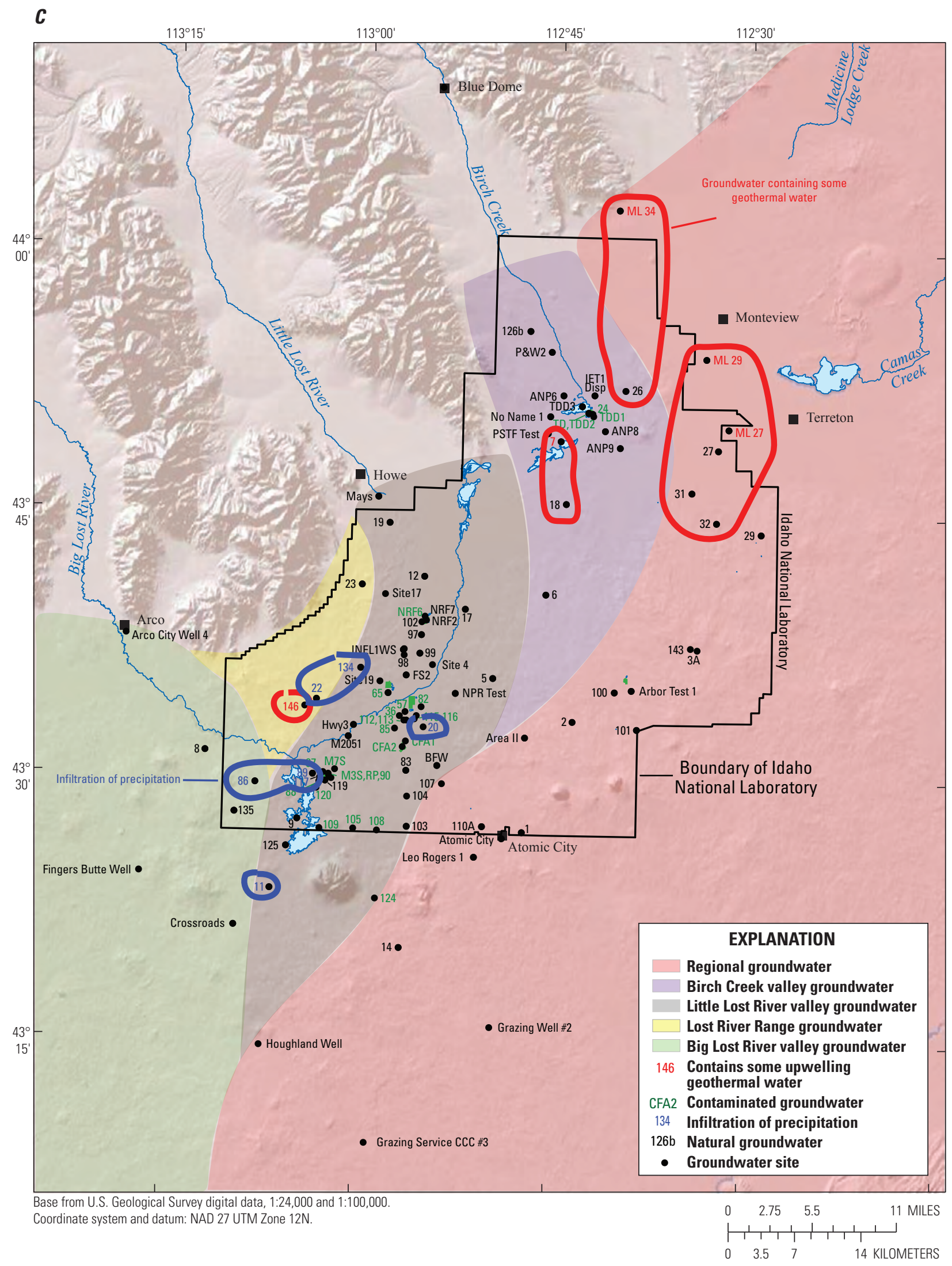

Figure 15.-Continued 


\section{Groundwater}

The primary groundwater sources of recharge (table 11 and fig. 15A) were:

- regional groundwater inflow in the Northeast and Southeast INL Areas (fig. 7),

- groundwater inflow from the BC valley in the North INL Area and the northern part of the Central INL Area,

- groundwater inflow from the LLR valley in the southern part of the Central INL Area and the eastern parts of the Northwest and Southwest INL Areas.

- groundwater inflow from the Lost River Range in the western part of the Northwest INL Area, and

- groundwater inflow from the BLR valley in the western part of the Southwest INL Area.

\section{Surface Water}

Recharge in the ERSP aquifer from the BLR is shown on figure $15 B$ with hand-drawn contour intervals that depict areas where the BLR contributed as much or more than 75,50 , and 25 percent of the total recharge to groundwater. The 75 percent contour interval for the BLR includes parts of the Central, Northwest, and Southwest INL Areas (figs. 7 and 15B). The 50 percent contour interval includes the IET 1 Disposal well in the North INL area and extends farther south and west than the 75 percent contour interval, and the 25 percent contour includes most of the North INL Area and extends farther south than the 50 percent contour interval (fig. 15B).

The 75 percent contour interval for the BLR indicates that the BLR provides a large amount of recharge to the Central, Northwest, and Southwest INL Areas. This interpretation is supported by tritium activities (table 8) in 6 of the 11 natural groundwater samples (Badging Facility Well, NPR Test, USGS 5, USGS 9, USGS 17, and USGS 103) within the contour interval that indicate that this groundwater was either young groundwater or a mixture of young and old groundwater (Rattray, 2018, fig. 28BB). Four of the natural groundwater samples within the contour interval had either a large uncertainty (USGS 83) or were old or mostly old groundwater based on low-level tritium measurements from 2001 (NRF 7) or 2017 (USGS 117, USGS 119). However, groundwater at NRF 7 periodically consists of young recharge from the BLR (appendix 1) and groundwater at USGS 117 and USGS 119 may be paleorecharge from the BLR (Rattray, 2018). The tritium activity for USGS 6 , the other natural groundwater within the contour interval, indicated that this groundwater was also old groundwater. Most groundwater at USGS 6 originated as recharge from the BLR (table 11) about 8 mi upgradient at playa 3 (fig. 7), and the small tritium activity at USGS 6 indicates that this recharge probably occurred prior to 1952 when atmospheric bomb testing began.

\section{Precipitation}

Precipitation was considered a small source of recharge to the ESRP aquifer at the INL (Ackerman and others, 2006). Recharge of precipitation, however, was required as an initial solution (table 10) to obtain plausible geochemical models for groundwater from seven wells (USGS 11, USGS 20, USGS 22, USGS 86, USGS 89, USGS 117, and USGS 134) in the southwestern part of the INL (fig. 15C).

The water chemistry of snow (tables 6-8) was used as the initial solution for precipitation for all wells except USGS 22. Groundwater from USGS 22 had a relatively large $\delta^{18} \mathrm{O}$ value (Rattray, 2018, fig. 28U), so summer precipitation, which has larger $\delta^{18} \mathrm{O}$ values than winter precipitation (Rightmire and Lewis, 1987; Benjamin and others, 2004), seemed a more likely source of recharge to this well than winter precipitation. Consequently, the precipitation-weighted annual average water chemistry of precipitation at Craters of the Moon (COM; tables 6-8) was used as the initial solution for precipitation at USGS 22. The snow water-chemistry used as an initial solution at a well was the snow site that was closest to the location of the well.

Two of the wells (USGS 22, USGS 134) with modeled recharge from precipitation were hydrologically upgradient of the BLR (fig. 15C). Groundwater at USGS 22 was modeled as consisting entirely of recharge from precipitation (table 11), which was consistent with prior interpretations about the origin of water at this well (Busenberg and others, 2001; Rattray, 2018). The large tritium activity in groundwater from USGS $22(160.9 \pm 0.4 \mathrm{pCi} / \mathrm{L}$; table 8$)$ indicated that precipitation recharge was recent, and probably occurred between 1954 and 1981 (Rattray, 2018, fig. 13A). Water may preferentially move vertically downward to this well instead of horizontally because of the small horizontal hydraulic conductivity $(<0.17 \mathrm{ft} / \mathrm{d}$; Rattray, 2018, table 11$)$ at this well. Groundwater at USGS 134 was modeled with recharge consisting of groundwater from the LLR valley, the LLR, and snow [initial solution(s)/sites(s) in table 11]. The tritium activity at USGS $134,17 \pm 1.9 \mathrm{pCi} / \mathrm{L}$, indicates that some young water is present in this groundwater (Rattray, 2018, fig. $28 \mathrm{BB}$ ). This site is about $11 \mathrm{mi}$ downgradient of the terminus of the LLR (fig. 7). Estimated average linear groundwater velocities were 2-14 ft/d for groundwater slightly east of USGS 134 (Ackerman and others, 2006); using the larger estimated velocity, recharge from the LLR could travel to USGS 134 in about 11 years. Thus, the young water at this well could originate from the LLR, and the modeled recharge from precipitation may represent more dilute recharge from the LLR than was used in modeling.

Five of the wells (USGS 11, USGS 20, USGS 86, USGS 89 , and USGS 117) with modeled recharge from precipitation were hydrologically downgradient of the BLR (fig. 15C). The tritium activities in groundwater from: 
- USGS 20 includes tritium from wastewater;

- USGS 11 is large and represents young groundwater; and

- USGS 86, USGS 89, and USGS 117 are small and represent old groundwater.

Because groundwater at USGS 20 is contaminated with wastewater it is difficult to determine whether precipitation is a source of water at this well or if it merely represents recharge from the BLR that was more dilute than available chemistry data that were used as initial solutions. Precipitation modeled as recharge at USGS 11 probably represents recharge from the BLR that was more dilute than available chemistry data that were used as initial solutions. Supporting evidence for this interpretation are:

- USGS 11 has a large (1995) tritium activity (31.8 \pm 0.2 $\mathrm{pCi} / \mathrm{L}$, table 8).

- USGS 11 is downgradient of the INL spreading areas (figs. 2 and 7).

- The BLR was diverted to the BLR spreading areas during 1995.

- Groundwater from wells adjacent to the BLR spreading areas have larger tritium activities than USGS 11 (table 8).

Rattray (2018) suggested that groundwater at wells USGS 86, USGS 89, and USGS 117 consisted of paleorecharge from the BLR based on geochemistry data and small horizontal hydrologic conductivities. Small tritium activities indicate that groundwater at these wells is either old or mostly old water (table 8). However, on a plot of strontium and uranium isotope ratios, groundwater from USGS 89 plots between values for the BLR and precipitation (Rattray, 2018, fig. 22B). This indicates that groundwater at USGS 89 may be a binary mixture of these two sources of recharge, consistent with results from geochemical modeling (table 11) and suggests that precipitation also is a plausible source of recharge at USGS 86 and USGS 117.

\section{Geothermal Water}

Large groundwater temperatures (table 6; Rattray, 2018, fig. 28A), large helium concentrations (Rattray, 2018, fig. $28 \mathrm{E}$ ), large percentages of terrigenic helium (Rattray, 2018, fig. 28CC), and a large helium isotope ratio (at USGS 27; Rattray, 2018, fig. 28Y), were used to indicate groundwater at the INL that contained geothermal water. These data indicated that geothermal water was present at the INL in deep groundwater (USGS 7), groundwater from three wells (USGS 26, USGS 27 , USGS 31) in the Northeast INL Area, groundwater from one well (USGS 18) in the Central INL Area, and groundwater from USGS 146 in the Northwest INL Area.

It was not clear from the temperature and helium data, however, whether the geothermal water at these wells was from vertical upwelling of geothermal water or from geothermally influenced groundwater flowing horizontally to these wells from upgradient areas (Rattray, 2015). Geothermal water in rhyolitic rock underlying the ESRP aquifer is a $\mathrm{Na}-\mathrm{HCO}_{3}$ water type similar to water from borehole INEL-1 10,300 feet (McLing and others, 2002; Rattray, 2018, fig. 10). The water chemistry from INEL-1 10,300 was previously used as an initial solution to model upwelling geothermal water in the Mud Lake area of the ESRP aquifer (Rattray, 2015), and water from USGS 7 and USGS 146 was modeled with initial solutions of 3 and 1 percent geothermal water from INEL-1 10,300 feet (table 10), respectively, indicating that vertical upwelling of geothermal water occurred at these wells. None of the other wells that appear to contain geothermal water had successful models with recharge from INEL-1 10,300 feet, indicating that geothermal water at these wells probably was from geothermally influenced groundwater flowing horizontally to these wells from upgradient areas (fig. 15C). The calculated percentage of geothermal water at these wells was 1.3 percent at USGS 27 (calculated from initial solutions for ML 27 and ML 29; Rattray, 2015), 0.4 percent at USGS 18, 0.3 percent at USGS 31 , and 0.2 percent at USGS 26 (calculated from initial solutions for ML 34; Rattray, 2015). Geochemical modeling indicated that groundwater at USGS 32 contained 0.7 percent geothermal water, but temperature and helium data do not support this result.

\section{Comparison with Other Studies that Estimated Sources of Recharge}

Sources of recharge at the INL were estimated in Rattray (2018) and with a groundwater-flow model (Fisher and others, 2012). A comprehensive suite of geochemistry data was analyzed in Rattray (2018) but estimates of groundwater sources of recharge (fig. 16A) were made mostly from strontium and uranium isotope data. With the groundwaterflow model, backward particle tracking was used to estimate groundwater source areas (fig. 16B-C).

\section{Comparison with Chapter A (Rattray, 2018)}

Areas showing whether recharge in the North, Northeast, Southeast, and Central INL Areas was primarily from regional groundwater, groundwater from the $\mathrm{BC}$ valley, or a mixture of the two were nearly identical between areas based on geochemical modeling (fig. 15A) and areas based largely on isotope ratios (fig. 16A). There were substantial differences, however, in areal depictions of groundwater sources of recharge in the Northwest and Southwest INL Areas. Isotope ratios (fig. 16A) indicated that (1) groundwater from the LLR valley flowed south and southwest and provided most of the recharge to the Northwest and Southwest INL Areas, (2) there was a small area of recharge from the Lost River Range along the northwest boundary of the INL in the Northwest INL Area, and (3) recharge from the BLR valley did not flow east toward the west INL boundary. In contrast, geochemical modeling (fig. 15A) indicated that (1) groundwater from the LLR valley 


\section{$\boldsymbol{A}$}

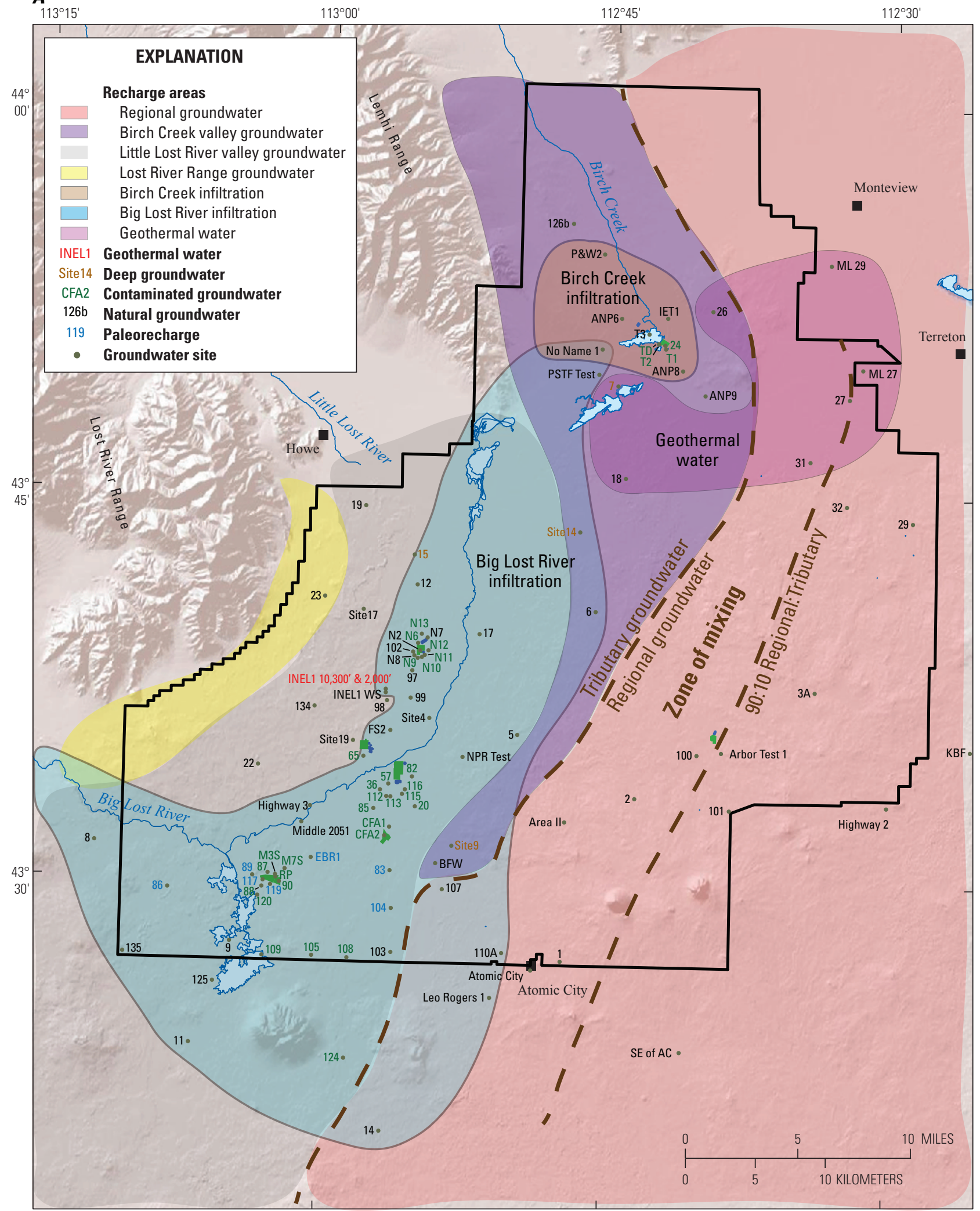

Base from U.S. Geological Survey digital data, 1:24,000 and 1:100,000.

Coordinate system and datum: NAD 27 UTM Zone 12N.

Figure 16. Sources of recharge, Idaho National Laboratory and vicinity, eastern Idaho. $(A)$ Groundwater sources of recharge estimated in Rattray (2018); (B) Groundwater source areas for model layer 1 estimated with a groundwater-flow model and backward particle tracking; and $(C)$ Groundwater source areas for well NPR-W01 estimated with a groundwaterflow model and backward particle tracking. 


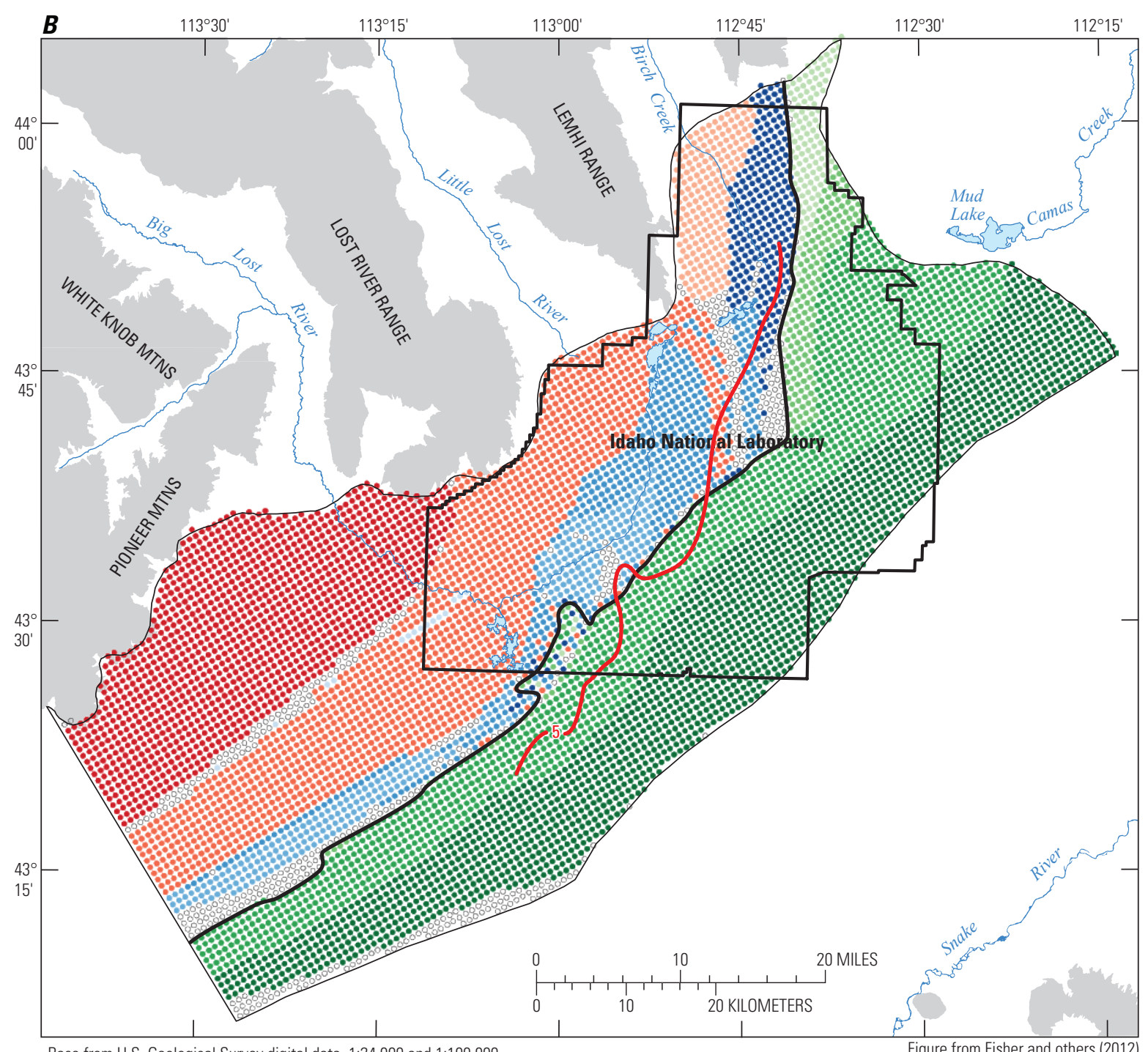

Base from U.S. Geological Survey digital data, 1:24,000 and 1:100,000

Albers Equal-Area Conic projection, standard parallels $42^{\circ} 50^{\prime} \mathrm{N}, 44^{\circ} 10^{\prime} \mathrm{N}$;

central meridian $113^{\circ} 00^{\prime} \mathrm{W}$; North American Datum of 1927.

\section{EXPLANATION}

\section{- Model area boundary \\ $-5-5$-microgram-per-liter lithium \\ concentration isopleth-Applies only to the upper 200 feet of the aquifer}

Particles starting location and source area in model layer 1-layer is about 100 feet thick, varying with the water-table altitude. $\mathrm{n}$ is the number of particles that terminate in a designated source area.

\section{Northwest mountain-front boundary source areas}

- Big Lost River valley $(n=1,199)$

- Little Lost River valley $(n=1,410)$

- Birch Creek valley $(n=200)$

Northeast regional-underflow boundary source areas

- Northeast boundary Reno section $(n=125)$

- Northeast boundary Monteview section $(n=188)$

- Northeast boundary Mud Lake section $(n=1,370)$

- Northeast boundary Terreton section $(n=1,734)$

\section{Streamflow infiltration source areas}

Big Lost River stream reaches 600 and $601(n=15)$

- Big Lost River spreading area, stream reaches 602 and $605(\mathrm{n}=0)$

- Big Lost River stream reaches 606 and $607(n=302)$

- Big Lost River sinks and playas, stream reaches 608 and $610(n=461)$

- Little Lost River stream reach $611(\mathrm{n}=0)$

- Birch Creek stream reach $612(n=270)$

Orphans

- Particles that did not terminate in one of the specified source areas $(n=426)$

Figure 16.-Continued 


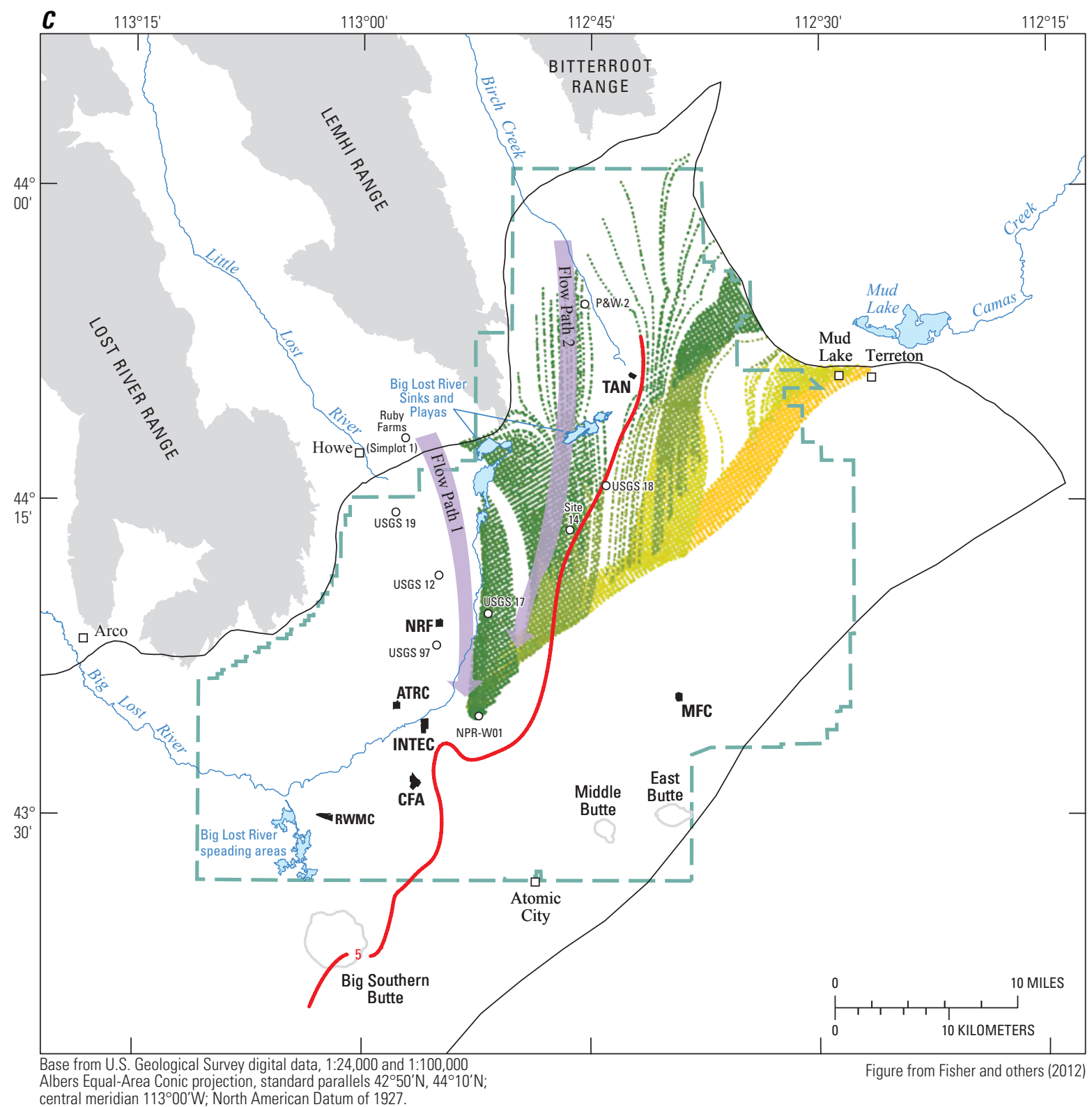

EXPLANATION

Model area boundary

Idaho National Laboratory boundary

\section{Site facilities}

ATRC-Advanced Test Reactor Complex

CFA-Central Facilities Area

INTEC - Idaho Nuclear Technology and Engineering Center MFC-Materials and Fuels Complex

NRF-Naval Reactors Facility

RWMC-Radioactive Waste Management Complex

TAN-Test Area North
Particle pathlines with starting locations in model layers 1 and 2 and within a 2,000 foot radius of well NPR-W01.

.... Particles traveling in model layer 1

.... Particles traveling in model layer 2

$\ldots$ Particles traveling in model layer 3

$\ldots$ Particles traveling in model layer 4

Sampled flow path-Schramke and others (1996) identified water chemistry along 2 groundwater flow paths

O Well and identifier-Nine wells were sampled, four along flow NPR-W01 path 1, and four along flow path 2 in addition to NPR-W01.

$5-5$ microgram per liter lithium concentration isopleth

Figure 16.-Continued 
generally flowed south and only provided recharge to the eastern parts of the Northwest and Southwest INL Areas, (2) most of the western part of the INL consisted of recharge of groundwater from the Lost River Range, and (3) recharge from the BLR valley extended east to the just inside western INL boundary.

The agreement between the two methods used to identify sources of recharge for the eastern half of the INL provided confidence that the groundwater sources of recharge were accurately identified, whereas the lack of agreement between the methods for the western half of the INL provided uncertainty about groundwater source areas. However, limited strontium and uranium isotope ratios were available to identify groundwater sources of recharge in the Northwest INL Area, and no strontium and uranium isotope ratios were available to characterize recharge of groundwater from the BLR valley and the Lost River Range. In contrast, major ion data were available for all groundwater sites in the Northwest INL Area, groundwater from the BLR valley, and groundwater from the Lost River Range (assuming groundwater from USGS 23 was representative of groundwater from the Lost River Range). Thus, geochemical modeling with major ion data probably provided a more accurate representation than isotope ratios did of the groundwater sources of recharge.

Geochemical modeling (fig. 15C) and chemical and isotopic data (fig. 16A) indicated that some groundwater in the Northeast and Central INL Areas contained geothermal water. However, geochemical modeling indicated that upwelling of geothermal water occurred only at USGS 7 (deep groundwater upgradient of the Central INL Area) and USGS 146 (in the Northwest INL Area). As described in section, "Geothermal Water", geothermal water in the Northeast INL Area originated as vertical upwelling of geothermal water north and northeast of the INL (Rattray, 2015) that subsequently flowed horizontally downgradient into the Northeast INL Area. Similarly, upwelling geothermal water near USGS 7 (fig. 15C) mixed with shallow groundwater that subsequently flowed horizontally downgradient into the Central INL Area.

Comparison of surface water recharge from the BLR (figs. 15B and 16A) shows slight variation between methods using isotope ratios and geochemical modeling. The most significant differences were that geochemical modeling represented recharge from the BLR occurring farther northeast and not as far west as indicated from isotope ratios. Uranium and strontium isotope ratios were not available for groundwater from the BLR valley, so geochemical modeling with major ion data probably provided a more accurate representation of recharge from the BLR than isotope ratios. Isotopic ratios indicated that $\mathrm{BC}$ was a source of recharge to the North INL Area (fig. 16A), which was consistent with BC as an initial solution in most geochemical modeling results for the North INL Area (table 11).

\section{Comparison with Groundwater Flow Model}

Sources of recharge were determined with the geochemical model (fig. 15A) and with backward particletracking simulations (Fisher and others, 2012) calculated using a steady-state groundwater-flow model (Ackerman and others, 2010). The backward particle tracking simulated sources of water to model layer 1 of the flow model (fig. 16B) and well NPR W01 (fig. 16C). Sources of recharge at well NPR W01 determined from the particle-tracking simulations were compared to sources of recharge determined from geochemical modeling at well NPR Test (fig. 16A) that is adjacent to well NPR W01 (fig. 16C).

Model boundaries and hydrologic inputs for regional groundwater and from the tributary valley groundwater essentially were the same between the geochemical and flow models. Differences in representation of boundaries and hydrologic inputs were:

- Recharge from the BLR was represented during a period when the BLR flowed onto the INL in the geochemical model and as the average of flow and no flow periods in the flow model.

- Recharge from $\mathrm{BC}$ was represented as occurring in the $\mathrm{BC}$ valley/North INL Area in the geochemical model and, due to diversion, near the Reno Ranch well north of the INL in the flow model.

- Groundwater flowing into the ESRP aquifer from the Lost River Range was represented in the geochemical model but not in the flow model.

- Recharge from precipitation and geothermal water was represented as a point source in the geochemical model and was not represented with particle tracking.

Due to these differences between the models, recharge

- from the BLR was greater in the geochemical model than in the flow model;

- from BC was not represented in the geochemical model but was represented along the north INL boundary in the flow model;

- of groundwater from the Lost River Range was represented in the geochemical model but not in the flow model;

- from precipitation and geothermal water was represented at specific locations in the geochemical model and not at all with particle tracking.

Other differences between the geochemical and flow model were:

- The geochemical model encompasses the upper 250 $\mathrm{ft}$ of the aquifer, whereas model layer 1 of flow model encompasses only the upper $100 \mathrm{ft}$. 
- Well NPR Test had an open interval of about 33 to $68 \mathrm{ft}$ below the water table (Rattray, 2018, table 11), whereas particles were released in the flow model in a cylinder with a 2000-ft radius centered on well NPR W01 in the upper $200 \mathrm{ft}$ of the aquifer (model layers 1 and 2; Fisher and others, 2012).

Representation of recharge of regional groundwater in the Northeast and Southeast INL Areas were generally consistent between the geochemical (fig. 15A) and groundwater-flow models (fig. 16B), although the flow model indicated that regional groundwater flows slightly farther west than was indicated with the geochemical model. However, the two models have some inconsistencies in the representation of recharge of groundwater from the tributary valleys and the Lost River Range. These inconsistencies were:

- Groundwater from the BC valley was represented as extending farther south with the geochemical model.

- Groundwater from the LLR valley was represented as extending farther west with the groundwater-flow model.

- Groundwater from the BLR valley was represented as extending farther southeast with the geochemical model.

- Groundwater from the Lost River Range was represented in the far western part of the INL with the geochemical model but not with the groundwater-flow model.

- Immediately south of the INL, the flow model indicated that groundwater flowed in a northeast-to-southwest direction, whereas geochemical modeling indicated that groundwater flowed in a north-northeast-to-southsouthwest direction.

Comparison of groundwater source areas between geochemical modeling and the flow model would be improved by combining particle tracking results from model layers 1 and 2 (the upper $200 \mathrm{ft}$ of the aquifer; Fisher and others, 2012). However, the flow model would be improved by including recharge of groundwater from the Lost River Range. Resolving the other differences in recharge of groundwater between the two models will probably require testing alternative conceptual models.

Recharge from $\mathrm{BC}$ was added to groundwater from the $\mathrm{BC}$ valley when tabulating sources of recharge identified with geochemical modeling. Therefore, recharge from $\mathrm{BC}$ was not explicitly represented in table 11 . However, geochemical modeling (table 10) did indicate that recharge from $\mathrm{BC}$ occurred in the North INL Area and that recharge from $\mathrm{BC}$ extended into the Northeast INL Area (from backward extrapolation for USGS 26). Particle tracking shows recharge from $\mathrm{BC}$ extending in a north-to-south direction from the north INL boundary to the central part of the INL, with the northern extent of recharge from $\mathrm{BC}$ occurring east of the mouth of the BC valley (fig. 16B). The groundwater-flow model probably provided a good representation of recharge from BC after diversion of BC north of the INL began in 1969.
Representation of recharge from the BLR in the Central INL Area was similar between the geochemical and groundwater-flow models (figs. 15B and 16B). However, geochemical modeling indicated a much larger spatial distribution of recharge from the BLR in the Southwest INL Area than did the flow model. This may indicate that the flow model underrepresents recharge from the BLR in the Southwest INL Area during periods when there is flow in the BLR channel and INL spreading areas.

Particle tracking indicated that recharge from the BLR (48.8 percent) and regional groundwater ( 35.5 percent) were significant sources of recharge at well NPR W01 (table 5), whereas geochemical modeling indicated that the dominant source of recharge at well NPR Test was the BLR (87 percent). These results suggest that regional groundwater is represented as flowing too far west in the flow model. However, comparison of these results should be used with caution because they do not represent the same aquifer depths. The comparison would be improved by simulating release of particles at NPR W01 in just model layer 1 (the upper $100 \mathrm{ft}$ of the aquifer) of the flow model.

Table 5. Sources of recharge from model results at wells NPR W01 and NPR Test, Idaho National Laboratory, eastern Idaho.

[Source of recharge: Orphans, particles that did not terminate at a specified source area (Fisher and others, 2012, table 5). Recharge at well: NPR W01, groundwater-flow model; NPR Test, geochemical model. -, none]

\begin{tabular}{lcc}
\hline \multicolumn{1}{c}{$\begin{array}{c}\text { Source of } \\
\text { recharge }\end{array}$} & \multicolumn{2}{c}{ Recharge at well (percent) } \\
\cline { 2 - 3 } & NPR W01 & NPR Test \\
\hline Big Lost River & 48.8 & 87 \\
Regional groundwater & 35.3 & - \\
Groundwater from the & 3.6 & 12 \\
$\quad$ Little Lost River valley & & \\
Birch Creek & 0.6 & 1 \\
Orphans & 11.7 & - \\
\hline
\end{tabular}

\section{Mixing of Water}

Mixing of water in geochemical modeling refers to model results that include two or more initial solutions. Mixing as part of this study may include surface water moving downward through the unsaturated zone that mixes with groundwater, upwelling geothermal water that mixes with groundwater, or convergence of two or more groundwaters moving along different flow paths. However, mixing of two or more groundwaters also may represent mixing of groundwater with different water compositions due to temporal and spatial variability, solute dispersion, sampling of water from different aquifer depths, and mixing of water from different aquifer depths during sample collection.

Geochemical modeling indicated that mixing of water was an important hydrologic feature in the ESRP aquifer at the INL. Significant mixing occurred between (1) tributary valley water and regional groundwater and (2) surface water infiltrating from 
the BLR with groundwater in the aquifer. However, infiltration of precipitation and upwelling of geothermal water provided only limited, localized mixing with groundwater (see sections, "Precipitation" and "Geothermal Water").

Mixing between tributary valley water (combined surface water from the BLR and surface water and groundwater from the LLR and BC valleys) and regional groundwater occurred in the Northeast and Southeast INL Areas (figs. 7 and 17). Two dashed lines on figure 17 show the location of $0: 100$ and 90:10 mixing ratios between regional groundwater and tributary valley water. Groundwater west of the line representing a 0:100 mixing ratio originates from the tributary valleys, groundwater east of the line representing a 90:10 mixing ratio is essentially regional groundwater. Mixing between these two sources of water occurs in the area between the lines, and this mixing zone extends in a north-northeast to south-southwest direction from the northeast boundary of the INL to south of the INL.

The BLR provided recharge across much of the study area (fig. 15B). Mixing of surface water from the BLR occurred in the

- North INL Area with surface water from BC (table 10) and groundwater from the $\mathrm{BC}$ valley,

- Central INL Area with groundwater from the BC and LLR valleys,

- Southeast INL Area with regional groundwater,

- Northwest INL Area with groundwater from the LLR valley, and

- Southwest INL Area with groundwater from the LLR valley and the Lost River Range.

\section{Groundwater Flow Directions}

Groundwater flow directions were represented with arrows (fig. 18) (1) through the center of the areas representing recharge of groundwater from the Lost River Range, the LLR valley, and the $\mathrm{BC}$ valley; (2) approximately parallel to the eastern extent of the area representing recharge of groundwater from the BLR valley; and (3) approximately parallel to the mixing ratio lines for tributary valley water and regional groundwater. All these arrows were approximately perpendicular to water-table contours, which provided confidence that the areas delineating groundwater sources of recharge and mixing of tributary valley water with regional groundwater were accurate because it showed that these areas, which were based on geochemistry data, were consistent with groundwater flow directions, based on potentiometric measurements.

Regional groundwater initially flows south in the eastern part of the INL and transitions to a south-southwest flow direction in the southeastern part of the INL (fig. 18). Groundwater from the LLR and BC valleys initially flows southeast onto the INL, following the alignment of their valleys, but eventually flows south-southwest parallel to the flow direction of regional groundwater. Consequently, tributary valley groundwater flow directions appear to be controlled initially by the alignment of their valleys with the subsequent flow direction responding and conforming to the direction of flow of regional groundwater. Groundwater from the Lost River Range flows south for a short distance, and groundwater from the BLR valley probably flows south initially before transitioning to a southsouthwest flow direction.

\section{Summary and Conclusions}

Geochemical modeling indicated that the primary chemical reactions in the eastern Snake River Plain (ESRP) aquifer at the Idaho National Laboratory (INL) were precipitation of calcite and dissolution of plagioclase (An60) and basalt volcanic glass. Secondary minerals other than calcite included calcium montmorillonite and goethite. Calcium montmorillonite precipitated as a reaction product during incongruent dissolution of plagioclase (An60) and basalt volcanic glass, and goethite precipitated because relatively insoluble ferrous iron was released to solution from dissolution of basalt volcanic glass and olivine (Fo85). Reverse cation exchange, consisting of sodium exchanging for calcium on clay minerals, occurred near site facilities (Test Area North, Idaho Nuclear Technology and Engineering Center, and Central Facilities Area) where large amounts of sodium were released to the ESRP aquifer in wastewater discharge and acted to retard the movement of wastewater-derived sodium in the aquifer.

Regional groundwater was the primary source of recharge to the eastern part of the INL, and regional groundwater providing recharge to the Northeast INL Area was influenced by geothermal water. Birch Creek (BC), the Big Lost River (BLR), and groundwater from $\mathrm{BC}$ valley provided recharge to the North INL Area, and the BLR and groundwater from BC valley provided recharge to the Central INL Area. In addition, groundwater at USGS 18, in the northern part of the Central INL Area, was influenced by geothermal water. The BLR, groundwater from the LLR valley and the Lost River Range, and precipitation provided recharge to the western part of the INL. However, some groundwater from wells that included precipitation as a source of recharge in the Southwest INL Area had small tritium activities, indicating that some of this water may consist of paleorecharge from the BLR and (or) precipitation. The primary source of recharge west and southwest of the INL was groundwater from BLR valley.

Recharge of surface water occurred in the North, Central, Northwest, and Southwest INL Areas. Infiltration recharge of surface water in these areas transported carbon dioxide and oxygen downward to the aquifer, which indicates that much of the aquifer in these areas is a dynamic, open system. In contrast, the aquifer in the Northeast and Southeast INL Areas receives little recharge from surface water and is a relatively static, closed system. 


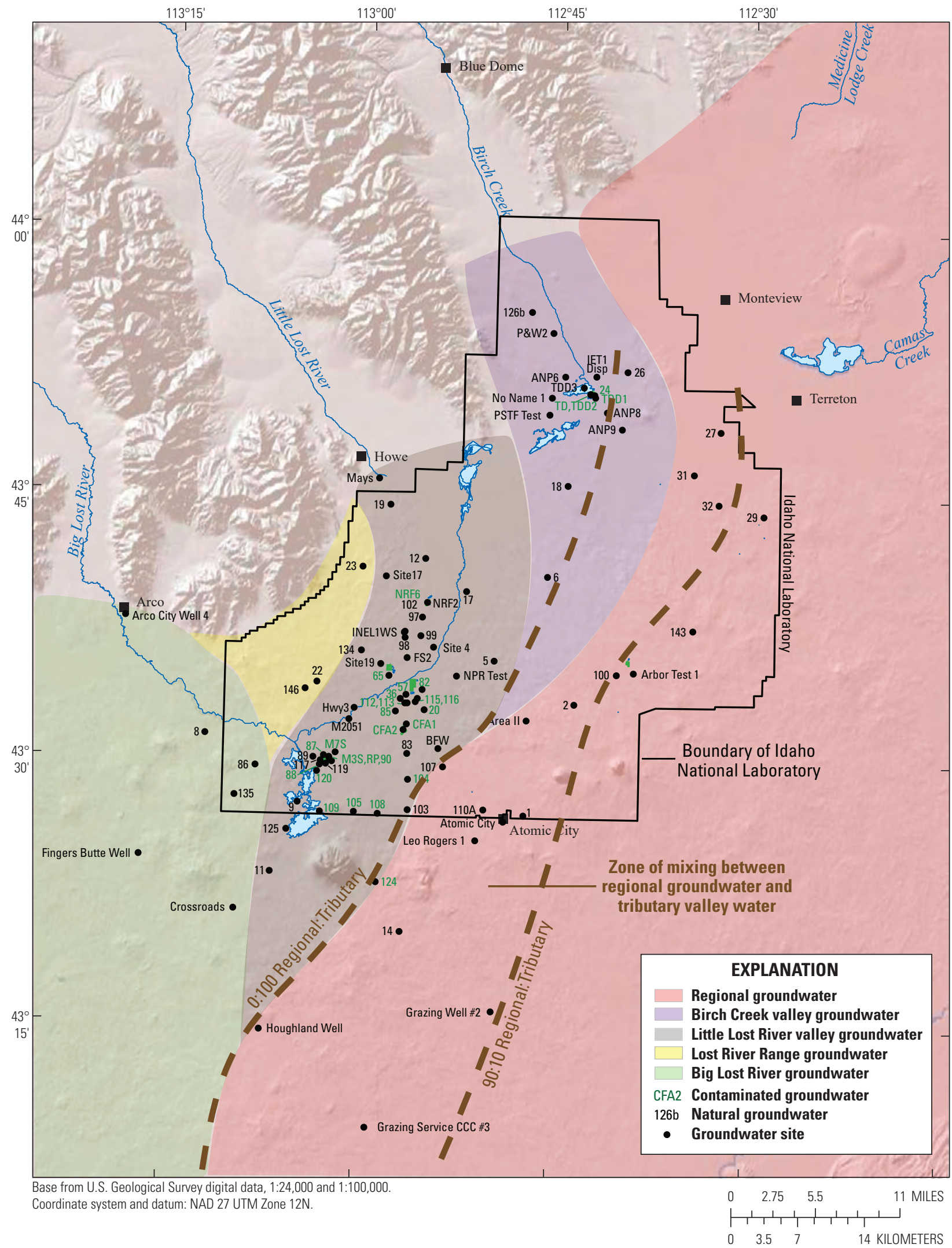

Figure 17. Mixing lines and zone of mixing between regional groundwater and tributary valley water, Idaho National Laboratory and vicinity, eastern Idaho. 


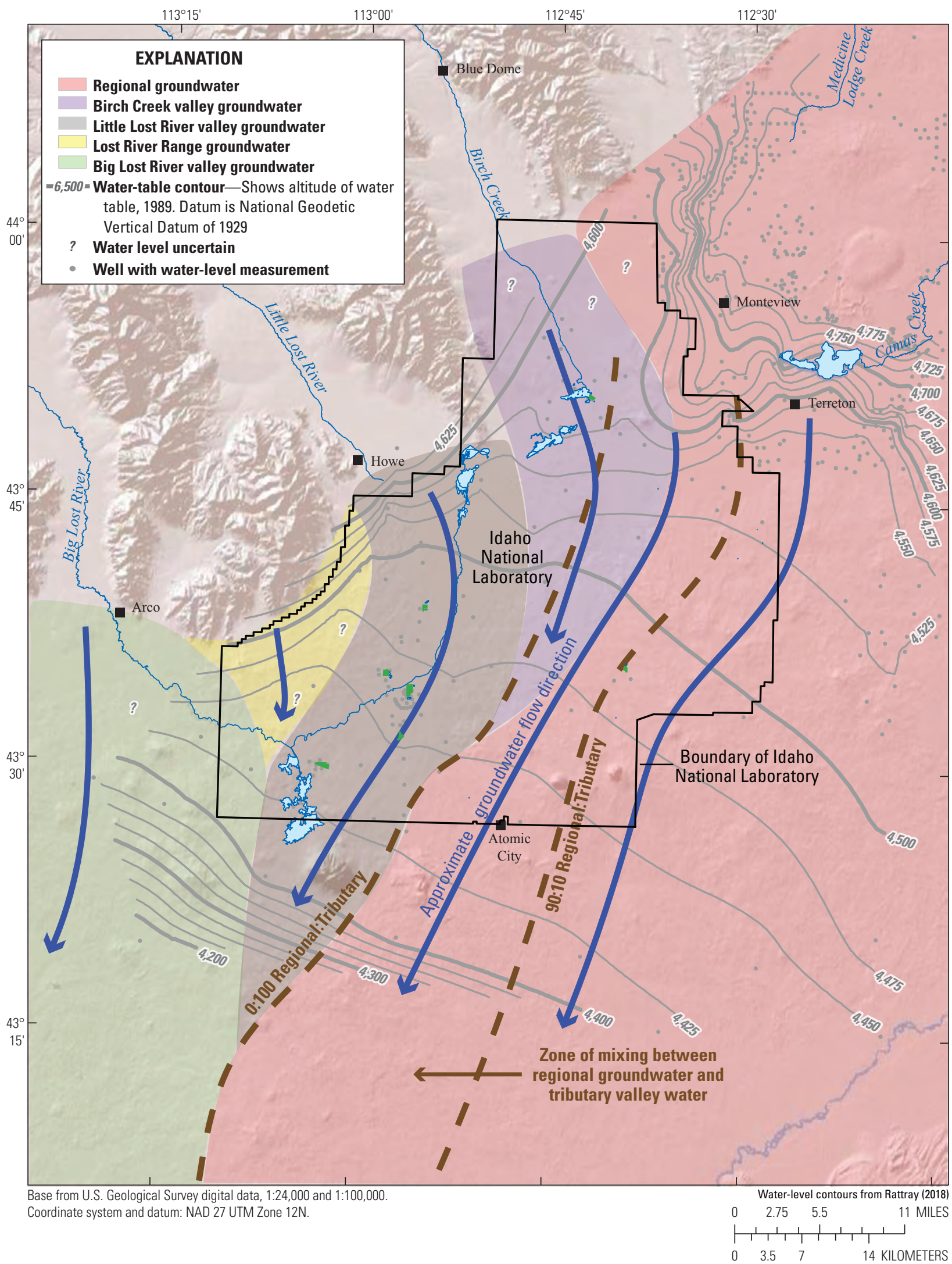

Figure 18. Water-table contours for 1989 and approximate groundwater-flow directions based on groundwater sources of recharge and mixing lines, Idaho National Laboratory and vicinity, eastern Idaho. 
Sources of recharge identified from isotope ratios and geochemical modeling (major ion concentrations) were nearly identical for the North, Northeast, Southeast, and Central INL Areas, which indicated that both methods probably accurately identified the sources of recharge in these areas. On the other hand, isotope ratios indicated that the BLR and groundwater from the LLR valley provided most recharge to the western parts of the Northwest and Southwest INL Areas, whereas geochemical modeling indicated a smaller area of recharge from the BLR and groundwater from the LLR valley, a larger area of recharge from the Lost River Range, and recharge of groundwater from the BLR valley that extended to the west INL boundary. The geochemical model results probably were more accurate than results from isotope ratios because major ion concentrations, but not isotope ratios, were available to characterize groundwater from the BLR valley and the Lost River Range.

Sources of recharge identified with particle tracking and geochemical modeling were similar for the Northeast and Southeast INL Areas. However, differences were that the geochemical model represented (1) recharge of groundwater from the Lost River Range in the western part of the INL, whereas the groundwater-flow model did not, (2) recharge of groundwater from the $\mathrm{BC}$ and $\mathrm{BLR}$ valleys extending farther south and east, respectively, than the flow model, and (3) more recharge from the BLR in the Southwest INL Area than did the flow model.

Mixing of water included (1) mixing of regional groundwater and water from the $\mathrm{BC}$ valley in the Northeast and Southeast INL Areas and (2) mixing of surface water (primarily from the BLR) and groundwater across much of the North, Central, Northwest, and Southwest INL Areas. Localized recharge from precipitation mixed with groundwater in the Northwest and Southwest INL Areas, and localized upwelling geothermal water mixed with groundwater in the Central and Northeast INL Areas. Flow directions of regional groundwater were south in the eastern part of the INL and south-southwest at downgradient locations. Groundwater from the BC and LLR valleys initially flowed southeast before changing to southsouthwest flow directions that paralleled regional groundwater, and groundwater from the BLR valley initially flowed south before changing to a south-southwest direction.

Geochemical modeling was used to evaluate the movement of wastewater-contaminated groundwater in the ESRP aquifer at and downgradient of the Idaho Nuclear Technology and Engineering Center (INTEC) and the Naval Reactors Facility (NRF). Wastewater-contaminated groundwater flowed south from the INTEC infiltration ponds in a narrow plume. The percentage of wastewater in groundwater decreased from about $60-80$ percent wastewater $0.7-0.8$ mile (mi) south of the INTEC infiltration ponds to about 1.4 percent wastewater about $15.5 \mathrm{mi}$ south of the INTEC infiltration ponds. Wastewater-contaminated groundwater flowed southeast and then southwest from the NRF industrial waste ditch. The percentage of wastewater in groundwater decreased from about 100 percent wastewater adjacent to the waste ditch to about 2 percent wastewater about $0.6 \mathrm{mi}$ south of the waste ditch. The short distance that wastewater discharged at NRF seemed to travel, compared to the long distance that wastewater discharged at INTEC traveled, was due to the much smaller volume of wastewater discharged at NRF that allowed contaminants in wastewater discharged at NRF to be diluted to small concentrations over a short distance.

\section{Acknowledgments}

The author thanks Pierre Glynn and Laura Bexfield of the U.S. Geological Survey for providing technical reviews that significantly improved this manuscript.

\section{References Cited}

Ackerman, D.J., Rattray, G.W., Rousseau, J.P., Davis, L.C., and Orr, B.R., 2006, A conceptual model of ground-water flow in the Eastern Snake River Plain aquifer at the Idaho National Laboratory and vicinity with implications for contaminant transport: U.S. Geological Survey Scientific Investigations Report 2006-5122 (DOE/ID-22198), 62 p.

Anderson, S.R., Kuntz, M.A., and Davis, L.C., 1999, Geologic controls of hydraulic conductivity in the Snake River Plain aquifer at and near the Idaho National Engineering and Environmental Laboratory, Idaho: U.S. Geological Survey Water-Resources Investigations Report 99-4033 (DOE/ ID-22155) 38 p. [Also available at http://pubs.er.usgs.gov/ publication/wri994033.]

Anderson, S.R., and Liszewski, M.J., 1997, Stratigraphy of the unsaturated zone and the Snake River Plain aquifer at and near the Idaho National Engineering Laboratory, Idaho: U.S. Geological Survey Water-Resources Investigations Report 97-4183 (DOE/ID-22142), 65 p.

Appelo, C.J., and Postma, D., 2005, Geochemistry, groundwater, and pollution ( $2 \mathrm{~d}$ ed.): Leiden, The Netherlands, A.A. Balkema Publishers, 649 p.

Atkins, P.W., 1986, Physical chemistry (3d ed.): New York, W.H. Freeman and Company, 857 p.

Barraclough, J.T., Lewis, B.D., and Jensen, R.G., 1981, Hydrologic conditions at the Idaho National Engineering Laboratory, Idaho, emphasis: 1974-1978: U.S. Geological Survey Open-File Report 81-256 (IDO-22060), 116 p.

Bartholomay, R.C., 1990, Mineralogical correlation of surficial sediment from area drainages with selected sedimentary interbeds at the Idaho National Engineering Laboratory, Idaho: U.S. Geological Survey Water-Resources Investigations Report 90-4177 (DOE/ID-22092), 18 p. 
Bartholomay, R.C., Hopkins, C.B., and Maimer, N.V., 2015, Chemical constituents in groundwater from multiple zones in the Eastern Snake River Plain aquifer at the Idaho National Laboratory, Idaho, 2009-13: U.S. Geological Survey Scientific Investigations Report 2015-5002 (DOE/ ID-22232), 109 p. [Also available at http://pubs.er.usgs.gov/ publication/sir20155002.]

Bartholomay, R.C., Knobel, L.L., and Davis, L.C., 1989, Mineralogy and grain size of surficial sediment from the Big Lost River drainage and vicinity, with chemical and physical characteristics of geologic materials from selected sites at the Idaho National Engineering Laboratory, Idaho: U.S. Geological Survey Open-File Report 89-384 (DOE/ ID-22081), $74 \mathrm{p}$.

Bartholomay, R.C., and Tucker, B.J., 2000, Distribution of selected radiochemical and chemical constituents in perched ground water, Idaho National Engineering and Environmental Laboratory, Idaho, 1996-98: U.S. Geological Survey Water-Resources Investigations Report 2000-4222 (DOE/ID-22168), 51 p., [Also available at http:// pubs.usgs.gov/wri/2000/4222/report.pdf.]

Bartholomay, R.C., Tucker, B.J., Ackerman, D.J., and Liszewski, M.J.R., 1997, Hydrologic conditions and distribution of selected radiochemical and chemical constituents in water, Snake River Plain aquifer, Idaho National Engineering Laboratory, Idaho, 1992 through 1995: U.S. Geological Survey Water-Resources Investigations Report 97-4086 (DOE/ID-22137), 57 p.

Bartholomay, R.C., Tucker, B.J., Knobel, L.L.C., and Mann, L.J.R., 2001, Radiochemical and chemical constituents in water from selected wells south of the Idaho National Engineering and Environmental Laboratory, Idaho: U.S. Geological Survey Open-File Report 01-138 (DOE/ ID-22175), $19 \mathrm{p}$.

Bartholomay, R.C., and Twining, B.V., 2010, Chemical constituents in groundwater from multiple zones in the Eastern Snake River Plain aquifer at the Idaho National Laboratory, Idaho, 2005-08: U.S. Geological Survey Scientific Investigations Report 2010-5116 (DOE/ ID-22211), $81 \mathrm{p}$.

Benjamin, L., Knobel, L.L., Hall, L.F., Cecil, L.D., and Green, J.R., 2004, Development of a local meteoric water line for southeastern Idaho, western Wyoming, and south-central Montana: U.S. Geological Survey Scientific Investigations Report 2004-5126 (DOE/ID-22191), 17 p.

Bennett, C.M., 1990, Streamflow losses and groundwater level changes along the Big Lost River at the Idaho National Engineering Laboratory, Idaho: U.S. Geological Survey Water-Resources Investigations Report 90-4067 (DOE/ ID-22091), 49 p.
Bethke, C.M., and Yeakel, S., 2017, The Geochemist's workbench, release 11-GWB essentials guide: Champaign, Illinois, Aqueous Solutions, LLC, 180 p.

Blair, J.J., 2002, Sedimentology and stratigraphy of sediments of the Big Lost Trough subsurface from selected boreholes at the Idaho National Engineering and Environmental Laboratory, Idaho: Pocatello, Idaho State University, M.S. Thesis, 162 p., http://geology.isu.edu/thesis/Blair James_2001.pdf.

Busenberg, E., Plummer, L.N., and Bartholomay, R.C., 2001, Estimated age and source of the young fraction of ground water at the Idaho National Engineering and Environmental Laboratory: U.S. Geological Survey Water-Resources Investigations Report 01-4265 (DOE/ID-22177), 144 p. [Also available at http://pubs.er.usgs.gov/publication/ wri014265.]

Busenberg, E., Plummer, L.N., Doughten, M.W., Widman, P.K., and Bartholomay, R.C., 2000, Chemical and isotopic composition and gas concentrations of ground water and surface water from selected sites at and near the Idaho National Engineering and Environmental Laboratory: U.S. Geological Survey Open-File Report 00-81 (DOE/ ID-22164), 51 p. [Also available at http://pubs.er.usgs.gov/ publication/ofro081.]

Carkeet, C., Rosentreter, J.J., Bartholomay, R.C., and Knobel, L.L., 2001, Geochemistry of the Big Lost River drainage basin, Idaho: U.S. Geological Survey Water-Resources Investigations Report 01-4031 (DOE/ID-22174), $31 \mathrm{p}$. [Also available at http://pubs.er.usgs.gov/publication/ wri014031.]

Cecil, L.D., Orr, B.R., Norton, T., and Anderson, S.R., 1991, Formation of perched ground-water zones and concentrations of selected chemical constituents in water, Idaho National Engineering Laboratory, Idaho: U.S. Geological Survey Water-Resources Investigations Report 91-4166 (DOE/ID-22100), 53 p. [Also available at https:// pubs.usgs.gov/wri/1991/4166/report.pdf]

Cecil, L.D., Welhan, J.A., Green, J.R., Frape, S.K., and Sudicky, E.R., 2000, Use of chlorine-36 to determine regional-scale aquifer dispersivity, eastern Snake River Plain aquifer, Idaho/USA: Nuclear Instruments and Methods in Physics Research, Section B, Beam Interactions with Materials and Atoms, v. 172, no. 1-4, p. 679-687.

Chapelle, F.H., and Knobel, L.L., 1983, Aqueous geochemistry and the exchangeable cation composition of glauconite in the Aquia aquifer, Maryland: Ground Water, v. 21, no. 3, p. 343-352.

Clark, I.D., and Fritz, P., 1997, Environmental isotopes in hydrogeology: Boca Raton, Florida, Lewis Publishers, 328 p. 
Davis, L.C., Bartholomay, R.C., and Rattray, G.W., 2013, An update of hydrologic conditions and distribution of selected constituents in water, eastern Snake River Plain aquifer and perched groundwater zones, Idaho National Laboratory, Idaho, emphasis 2009-11: U.S. Geological Survey Scientific Investigations Report 2013-5214 (DOE/ ID-22226), 89 p. [Also available at http://pubs.er.usgs.gov/ publication/sir20135214.]

Deer, W.A., Howie, R.A., and Zussman, J., 1983, An introduction to the rock forming minerals: Essex, England, Longman House, 528 p.

Deutsch, W.J., Jenne, E.A., and Krupka, K.M., 1982, Solubility equilibria in basalt aquifers-The Columbia Plateau, eastern Washington, U.S.A.: Chemical Geology, v. 36, nos. 1-2, p. 15-34.

Doherty, D.J., McBroome, L.A., and Kuntz, M.A., 1979, Preliminary geological interpretation and lithologic log of the exploratory geothermal test well (INEL-1), Idaho National Engineering Laboratory, eastern Snake River Plain, Idaho: U.S. Geological Survey Open-File Report 79-1248, $9 \mathrm{p}$.

Drever, J.I., 1997, The geochemistry of natural waters: Upper Saddle River, New Jersey, Prentice Hall, 436 p.

Fisher, J.C., Rousseau, J.R., Bartholomay, R.C., and Rattray, G.W., 2012, A comparison of U.S. Geological Survey threedimensional model estimates of groundwater source areas and velocities to independently derived estimates, Idaho National Laboratory and vicinity, Idaho: U.S. Geological Survey Scientific Investigations Report 2012-5152 (DOE/ID-22218), $130 \mathrm{p}$.

French, D.J., Lisee, D.J., and Taylor, K.A., 1995, Idaho National Engineering and Environmental Laboratory nonradiological waste management information for 1994 and record-to-date: U.S. Department of Energy, Idaho Operations Office [DOE/ID-10057(94)], variously paged.

French, D.J., Lisee, D.J., and Taylor, K.A., 1996, Idaho National Engineering and Environmental Laboratory nonradiological waste management information for 1995 and record-to-date: U.S. Department of Energy, Idaho Operations Office [DOE/ID-10057(95)], variously paged.

French, D.J., Lisee, D.J., and Taylor, K.A., 1997, Idaho National Engineering and Environmental Laboratory nonradiological waste management information for 1996 and record-to-date: U.S. Department of Energy, Idaho Operations Office [DOE/ID-10057(96)], variously paged.

Garabedian, S.P., 1992, Hydrology and digital simulation of the regional aquifer system, eastern Snake River Plain, Idaho: U.S. Geological Survey Professional Paper 1408-F, 102 p., 10 pls.
Geslin, J.K., Link, P.K., Riesterer, J.W., Kuntz, M.A., and Fanning, C.M., 2002, Pliocene and Quaternary stratigraphic architecture and drainage systems of the Big Lost Trough, northeastern Snake River Plain, Idaho, in Link, P.K., and Mink, L.L., eds., Geology, hydrogeology, and environmental remediation-Idaho National Engineering and Environmental Laboratory, Eastern Snake River Plain, Idaho: Geological Society of America Special Paper 353, p. 11-26, https://doi.org/10.1130/0-8137-2353-1.11.

Gianniny, G.L., Thackray, G.D., Kauffman, D.S., Forman, S.L., Sherbondy, M.J., and Findeisen, D., 2002, Late Quaternary highstands in the Mud Lake and Big Lost Trough subbasins of Lake Terreton, Idaho, in Link, P.K., and Mink, L.L., eds., Geology, hydrogeology, and environmental remediationIdaho National Engineering and Environmental Laboratory, Eastern Snake River Plain, Idaho: Geological Society of America Special Paper 353, p. 77-90, http://specialpapers. gsapubs.org/content/353/77.full.pdf + html.

Ginsbach, M.L., 2013, Geochemical evolution of groundwater in the Medicine Lodge Creek drainage basin, eastern Idaho: Pocatello, Idaho State University, M.S. Thesis, 241 p., http://geology.isu.edu/thesis/Ginsbach.Michael.2013.pdf.

Gronow, J.R., 1987, The dissolution of asbestos fibres in water: Clay Minerals, v. 22, p. 21-35.

Hem, J.D., 1992, Study and interpretation of the chemical characteristics of natural water (3d ed.): U.S. Geological Survey Water-Supply Paper 2254, 263 p. [Also available at http://pubs.er.usgs.gov/publication/wsp2254.]

Homer, C., Dewitz, J., Fry, J., Coan, M., Hossain, N., Larson, C., Herold, N., McKerrow, A., VanDriel, J.N., and Wickham, J., 2007, Completion of the 2001 national land cover database for the conterminous United States: Photographic Engineering and Remote Sensing, v. 73, no. 4, p. 337-341.

Idaho Department of Environmental Quality, 2015, Sole source aquifers: Idaho Department of Environmental Quality, accessed July 22, 2015, at http://deq.idaho.gov/ water-quality/ground-water/sole-source-aquifers.aspx.

Idaho Department of Water Resources, 2016, Eastern Snake River Plain: Irrigated Lands: 1996, accessed February 16, 2016, at http://research.idwr.idaho.gov/index.html\#GIS_Data.

Idaho Transportation Department, 2018, Road maintenanceWinter driving: Idaho Transportation Department web site, accessed February 21, 2018, at https://itd.idaho.gov/road-mtce/.

Johnson, T.M., Roback, R.C., McLing, T.L., Bullen, T.D., DePaolo, D.J., Doughty, C., Hunt, R.J., Smith, R.W., Cecil, L.D., and Murrell, M.T., 2000, Groundwater "fast paths" in the Snake River Plain aquifer-Radiogenic isotope ratios as natural groundwater tracers: Geology, v. 28, no. 10, p. 871-874. 
Kjelstrom, L.C., and Berenbrock, C., 1996, Estimated 100 -year peak flows and flow volumes in the Big Lost River and Birch Creek at the Idaho National Engineering Laboratory, Idaho: U.S. Geological Survey Water-Resources Investigations Report 96-4163, 23 p. [Also available at https://doi.org/10.3133/wri964163.]

Knobel, L.L., Bartholomay, R.C., Cecil, L.D., Tucker, B.J., and Wegner, S.J., 1992, Chemical constituents in the dissolved and suspended fractions of ground water from selected sites, Idaho National Engineering Laboratory and vicinity, Idaho, 1989: U.S. Geological Survey Open-File Report 92-51 (DOE/ID-22101), 56 p. [Also available at http://pubs.er.usgs.gov/publication/ofr9251.]

Knobel, L.L., Bartholomay, R.C., and Orr, B.R., 1997, Preliminary delineation of natural geochemical reactions, Snake River Plain aquifer system, Idaho National Engineering Laboratory and vicinity, Idaho: U.S. Geological Survey Water-Resources Investigations Report 97-4093 (ID/ DOE-22139), 52 p. [Also available at http://pubs.er.usgs. gov/publication/wri974093.]

Knobel, L.L., Bartholomay, R.C., Tucker, B.J., and Williams, L.M., 1999b, Chemical and radiochemical constituents in water from sites in the vicinity of the Naval Reactors Facility, Idaho National Engineering and Environmental Laboratory and vicinity, Idaho, 1996: U.S. Geological Survey Open-File Report 99-272 (DOE/ID-22160), 58 p. [Also available at https://pubs.er.usgs.gov/publication/ ofr99272.]

Knobel, L.L., Bartholomay, R.C., Tucker, B.J., Williams, L.M., and Cecil, L.D., 1999a, Chemical constituents in ground water from 39 selected sites with an evaluation of associated quality assurance data, Idaho National Engineering and Environmental Laboratory and vicinity, Idaho: U.S. Geological Survey Open-File Report 99-246 (DOE/ID-22159), 58 p. [Also available at https://pubs. er.usgs.gov/publication/ofr99246.]

Kuntz, M.A., Covington, H.R., and Schorr, L.J., 1992, An overview of basaltic volcanism of the eastern Snake River Plain, Idaho, chap. 12 of Link, P.K., Kuntz, M.A., and Platt, L.B., eds., Regional geology of eastern Idaho and western Wyoming: Geological Society of America Memoir 179, p. 227-267, https://doi.org/10.1130/MEM179-p227.

Lanphere, M.A., Champion, D.E., and Kuntz, M.A., 1993, Petrography, age, and paleomagnetism of basalt lava flows in coreholes Well 80, NRF 89-04, NRF 89-05, and ICPP 123, Idaho National Engineering Laboratory: U.S. Geological Survey Open-File Report 93-327, 40 p.

Lasaga, A.C., Soler, J.M., Ganor, J., Burch, T.E., and Nagy, K.L., 1994, Chemical weathering rate laws and global geochemical cycles: Geochimica et Cosmochimica Acta, v. 58, p. 2361-2386.
Lewis, R.S., Link, P.K., Stanford, L.R., and Long, S.P., 2012, Geologic map of Idaho: Idaho Geological Survey Map 9, scale 1:750,000, accessed September 14, 2015, at http://www.idahogeology.org/Products/reverselook. asp?switch=title\&value=Geologic_Map_of_Idaho.

Litteer, D.L., 1988, Industrial waste management information for 1987 and record-to-date: U.S. Department of Energy, Idaho Operations Office [DOE/ID-10057(87)], variously paged.

Litteer, D.L., and Peterson, C.N., 1990, Industrial waste management information for 1989 and record-to-date: U.S. Department of Energy, Idaho Operations Office [DOE/ ID-10057(89)], variously paged.

Litteer, D.L., Peterson, C.N., and Sims, A.M., 1991, Industrial waste management information for 1990 and record-to-date: U.S. Department of Energy, Idaho Operations Office [DOE/ ID-10057(90)], variously paged.

Litteer, D.L., Peterson, C.N., and Sims, A.M., 1992, Idaho National Engineering and Environmental Laboratory nonradiological waste management information for 1991 and record-to-date: U.S. Department of Energy, Idaho Operations Office [DOE/ID-10057(91)], variously paged.

Litteer, D.L., and Reagan, B.D., 1989, Industrial waste management information for 1988 and record-to-date: U.S. Department of Energy, Idaho Operations Office [DOE/ ID-10057(88)], variously paged.

Manahan, S.E., 1991, Environmental chemistry: Chelsea, Mich., Lewis Publishers, 583 p.

Mann, L.J., 1986, Hydraulic properties of rock units and chemical quality of water for INEL-1-a 10,365-foot deep test hole drilled at the Idaho National Engineering Laboratory, Idaho: U.S. Geological Survey Water-Resources Investigations Report 86-4020 (DOE/ID-22070), 23 p. [Also available at http://pubs.er.usgs.gov/publication/ wri864020.]

Mann, L.J., and Beasley, T.M., 1994, Iodine-129 in the Snake River Plain aquifer at and near the Idaho National Engineering Laboratory, Idaho, 1990-91: U.S. Geological Survey Water-Resources Investigations Report 94-4053 (DOE/ID-22115), 27 p. [Also available at http://pubs. er.usgs.gov/publication/wri944053.]

Mark, L.E., and Thackray, G.D., 2002, Sedimentologic and hydrologic characterization of surficial sedimentary facies in the Big Lost Trough, Idaho National Engineering and Environmental Laboratory, eastern Idaho, in Link, P.K., and Mink, L.L., eds., Geology, hydrogeology, and environmental remediation-Idaho National Engineering and Environmental Laboratory, Eastern Snake River Plain, Idaho: Geological Society of America Special Paper 353, p. 61-75, https://doi.org/10.1130/0-8137-2353-1.61. 
Mazurek, John, 2004, Genetic controls on basalt alteration within the eastern Snake River Plain aquifer system, Idaho: Pocatello, Idaho State University, M.S. Thesis, 215 p., https://isu.app.box.com/v/Mazurek-2004.

McLing, T.L., 1994, The pre-anthropogenic groundwater evolution at the Idaho National Engineering Laboratory, Idaho: Pocatello, Idaho State University, M.S. thesis, 62 p., https://isu.app.box.com/v/McLing-1994.

McLing, T.L., Smith, R.W., and Johnson, T.M., 2002, Chemical characteristics of thermal water beneath the eastern Snake River Plain, in Link, P.K., and Mink, L.L., eds., Geology, hydrogeology, and environmental remediation-Idaho National Engineering and Environmental Laboratory, Eastern Snake River Plain, Idaho: Geological Society of America Special Paper 353, p. 205-211.

Morgan, L.A., Doherty, D.J., and Leeman, P.L., 1984, Ignimbrites of the eastern Snake River Plain-Evidence for major caldera-forming eruptions: Journal of Geophysical Research, v. 89, no. B10, p. 8665-8678.

Morgan, L.A., and McIntosh, W.C., 2005, Timing and development of the Heise volcanic field, Snake River Plain, Idaho western USA: Geological Society of America Bulletin, v. 117, no. 3/4, p. 288-306.

Mundorff, M.J., Broom, H.C., and Kilburn, C., 1963, Reconnaissance of the hydrology of the Little Lost River basin, Idaho: U.S. Geological Survey Water-Supply Paper 1539-Q, p. Q1-Q51. [Also available at http://pubs.er.usgs. gov/publication/wsp1539Q.]

Nace, R.L., Deutsch, Morris, and Voegli, P.T., 1956, Geography, geology, and water resources of the National Reactor Testing Station, Idaho-Part 2. Geography and geology: U.S. Geological Survey Open-File Report (IDO22033), $225 \mathrm{p}$.

National Oceanic and Atmospheric Administration, 2015, NOAA INL Weather Center: U.S. Dept. of Commerce, accessed on September 10, 2015, at http://niwc.noaa.inel. gov/climate.htm.

Nilles, M.A., 2000, Atmospheric deposition program of the U.S. Geological Survey: U.S. Geological Survey Fact Sheet FS-112-00, 6 p. [Also available at https://doi.org/10.3133/ fs11200.]

Nimmo, J.R., Perkins, K.S., Rose, P.A., Rousseau, J.P., Orr, B.R., Twining, B.V., and Anderson, S.R., 2002, Kilometerscale rapid transport of naphthalene sulfonate tracer in the unsaturated zone at the Idaho National Engineering and Environmental Laboratory: Vadose Zone Journal, v. 1, issue 1, p. 89-101, https://doi.org/10.2136/vzj2002.8900.
Orr, B.R., and Cecil, L.D., 1991, Hydrologic conditions and distribution of selected chemical constituents in water, Snake River Plain aquifer, Idaho National Engineering Laboratory, Idaho, 1986 to 1988: U.S. Geological Survey Water-Resources Investigations Report 91-4047 (DOE/ ID-22096), $56 \mathrm{p}$.

Parkhurst, D.L., 1997, Geochemical mole-balance modeling with uncertain data: Water-Resources Research, v. 33, no. 8, p. 1957-1970.

Parkhurst, D.L., and Appelo, C.A.J., 2013, Description of input and examples for PHREEQC Version 3-A computer program for speciation, batch reaction, one-dimensional transport, and inverse geochemical calculations: U.S. Geological Survey Techniques and Methods, book 6, chap A43, 497 p. [Also available at http://pubs.usgs.gov/tm/06/ a43/.]

Pittman, J.R., Jensen, R.G., and Fischer, P.R., 1988, Hydrologic conditions at the Idaho National Engineering Laboratory, 1982 to 1985: U.S. Geological Survey WaterResources Investigations Report 89-4008 (DOE/ID-22078), $73 \mathrm{p}$.

Randall, V.C., and Sims, A.M., 1993, Idaho National Engineering and Environmental Laboratory nonradiological waste management information for 1992 and record-to-date: U.S. Department of Energy, Idaho Operations Office [DOE/ ID-10057(92)], variously paged.

Rattray, G.W., 2015, Geochemical evolution of groundwater in the Mud Lake area, eastern Idaho, USA: Environmental Earth Sciences, v. 73, no. 12, p. 8251-8269, https://doi. org/10.1007/s12665-014-3988-9.

Rattray, G.W., 2017, Estimated seepage rates from selected ditches, ponds, and lakes at the Camas National Wildlife Refuge, eastern Idaho: Journal of Environmental Management, v. 203, p. 578-591, https://doi.org/10.1016/j. jenvman.2017.02.063.

Rattray, G.W., 2018, Geochemistry of groundwater in the eastern Snake River Plain aquifer, Idaho National Laboratory, eastern Idaho: U.S. Geological Survey Professional Paper 1837-A (DOE/ID-22246), 198 p. [Also available at https://doi.org/10.3133/pp1837A.]

Rattray, G.W., and Ginsbach, M.L., 2014, Geochemistry of groundwater in the Beaver and Camas Creek drainage basins, eastern Idaho: U.S. Geological Survey Scientific Investigations Report 2013-5226 (DOE/ID-22227), 70 p. [Also available at http://pubs.usgs.gov/sir/2013/5226/.]

Rattray, G.W., and Sievering, H., 2001, Dry deposition of ammonia, nitric acid, and nitrate to alpine tundra at Niwot Ridge, Colorado: Atmospheric Environment, v. 35, p. 1105-1109, https://www.sciencedirect.com/science/article/ pii/S1352231000002764. 
Reed, M.E., and Bartholomay, R.C., 1994, Mineralogy of selected sedimentary interbeds at or near the Idaho National Engineering Laboratory, Idaho: U.S. Geological Survey Open-File Report 94-374 (DOE/ID-22116), 19 p.

Rightmire, C.T., 1984, Description and hydrogeologic implications of cored sedimentary material from the 1975 drilling program at the Radioactive Waste Management Complex, Idaho: U.S. Geological Survey Water-Resources Investigations Report 84-4071 (DOE/ID-22067), 33 p.

Rightmire, C.T., and Lewis, B.D., 1987, Hydrogeology and geochemistry of the unsaturated zone, Radioactive Waste Management Complex, Idaho National Engineering Laboratory, Idaho: U.S. Geological Survey Water-Resources Investigations Report 87-4198 (DOE/ID-22073), 89 p.

Robertson, J.B., Schoen, R., and Barraclough, J.T., 1974, The influence of liquid waste disposal on the geochemistry of water at the National Reactor Testing Station, Idaho1952-1970: U.S. Geological Survey Open-File Report (IDO-22053), 231 p. [Also available at http://pubs.er.usgs. gov/publication/ofr73238.]

Schramke, J.A., Murphy, E.M., and Wood, B.D., 1996, The use of geochemical mass-balance and mixing models to determine groundwater sources: Applied Geochemistry, v. 11, p. 523-539, https://doi.org/10.1016/08832927(96)00007-8.

Sibson, R., 1981, A brief description of natural neighbor interpolation, in Barnett, V., ed., Interpolating Multivariate Data: New York, John Wiley and Sons, p. 21-36.

Sims, A.M., and Taylor, K.A., 1994, Idaho National Engineering and Environmental Laboratory nonradiological waste management information for 1993 and record-to-date: U.S. Department of Energy, Idaho Operations Office [DOE/ ID-10057(93)], variously paged.

Spinazola, J.M., 1994, Geohydrology and simulation of flow and water levels in the aquifer system in the Mud Lake area of the eastern Snake River Plain, eastern Idaho: U.S. Geological Survey Water-Resource Investigations Report 93-4227, 78 p. [Also available at https://doi.org/10.3133/ wri934227.]

Swanson, S.A., Rosentreter, J.J., Bartholomay, R.C., and Knobel, L.L., 2002, Geochemistry of the Little Lost River drainage basin, Idaho: U.S. Geological Survey WaterResources Investigations Report 02-4120 (DOE-ID22179), 29 p. [Also available at https://doi.org/10.3133/wri934227.]
Swanson, S.A., Rosentreter, J.J., Bartholomay, R.C., and Knobel, L.L., 2003, Geochemistry of the Birch Creek drainage basin, Idaho: U.S. Geological Survey WaterResources Investigations Report 03-4272 (DOE-ID22188), 36 p. [Also available at https://doi.org/10.3133/wri024120.]

U.S. Department of Energy, 2011, Idaho National Laboratory groundwater monitoring and contingency plan update: U.S. Department of Energy, DOE/ID-11034, revision 2, [variously paged].

U.S. Geological Survey, 2016, Dissolved oxygen solubility tables: U.S. Geological Survey, accessed July 6, 2016, at http://water.usgs.gov/software/DOTABLES/.

U.S. Geological Survey, 2017, National Water Information System database: U.S. Geological Survey, accessed June 1, 2017, at http://waterdata.usgs.gov/nwis.

Welhan, J.A., Clemo, T.M., and Gego, E.L., 2002, Stochastic simulation of aquifer heterogeneity in a layered basalt aquifer system, eastern Snake River Plain, Idaho, in Link, P.K., and Mink, L.L., eds., Geology, hydrogeology, and environmental remediation: Idaho National Engineering and Environmental Laboratory, Eastern Snake River Plain, Idaho: Boulder, Colo., Geological Society of America Special Paper 353, p. 225-247.

Welhan, J.A., Johannesen, C.M., Reeves, K.S., Clemo, T.M., Glover, J.A., and Bosworth, K.W., 2002, Morphology of inflated pahoehoe lavas and spatial architecture of their porous and permeable zones, eastern Snake River Plain, Idaho, in Link, P.K., and Mink, L.L., eds., Geology, hydrogeology, and environmental remediation: Idaho National Engineering and Environmental Laboratory, Eastern Snake River Plain, Idaho: Boulder, Colo., Geological Society of America Special Paper 353, p. 135-150.

Whitehead, R.L., 1992, Geohydrologic framework of the Snake River Plain regional aquifer system, Idaho and eastern Oregon: U.S. Geological Survey Professional Paper 1408-B, 32 p., 6 pls. [Also available at http://pubs.er.usgs. gov/publication/pp1408B.]

Wood, W.W., and Low, W.H., 1988, Solute geochemistry of the Snake River Plain regional aquifer system Idaho and eastern Oregon: U.S. Geological Survey Professional Paper 1408-D, 79 p. 


\section{Tables 6-11}


Table 6. Measurements of field parameters, calculated partial pressure of carbon dioxide, and concentrations of aluminum and iron, Idaho National Laboratory and vicinity, eastern Idaho.

[Data from Busenberg and others (2000); Rattray (2015); Knobel and others (1992, 1999a, 1999b); U.S. Geological Survey National Water Information System (2017); Bartholomay and others (2001); Swanson and others (2002, 2003); Carkeet and others (2001); Bartholomay and Twining (2010); Bartholomay and others (2015); Rightmire and Lewis (1987); Mann (1986); and Johnson and others (2000). Location of sites shown in figures 1, 7, and 8. Alkalinity: Concentrations for data from Busenberg and others (2000) and Knobel and others (1992) were calculated from bicarbonate concentrations using the equation in Hem (1992). pH: Negative base-10 logarithm of the hydrogen ion activity. Dissolved oxygen: Some dissolved-oxygen (DO) values were not measured during sample collection. Consequently, some DO values were measured at another time, were calculated with the U.S. Geological Survey DO solubility tables (U.S. Geological Survey, 2016) assuming 100 percent saturation or, if DO values are preceded by a $\approx$ sign, were either estimated as the mean value of all DO measurements for that site in National Water Information System (NWIS) through December 2015 or were estimated from the DO value in water from nearby wells. Carbon dioxide: Log $\mathrm{PCO}_{2}$, base-10 logarithm of carbon dioxide partial pressure. Calculated with PHREEQC (Parkhurst and Appelo, 2013). Abbreviations: E, estimated; INL, Idaho National Laboratory; mg/L, milligram per liter; $\mu \mathrm{g} / \mathrm{L}$, microgram per liter; nd, not determined; sz, shallow zone. Symbols: ${ }^{\circ} \mathrm{C}$, temperature in degrees Celsius; $<$, less than]

\begin{tabular}{|c|c|c|c|c|c|c|c|c|}
\hline $\begin{array}{c}\text { Site } \\
\text { name }\end{array}$ & $\begin{array}{c}\text { Date } \\
\text { sampled }\end{array}$ & $\begin{array}{l}\text { Temperature } \\
\left({ }^{\circ} \mathrm{C}\right)\end{array}$ & $\mathrm{pH}$ & $\begin{array}{c}\text { Alkalin- } \\
\text { ity (mg/L as } \\
\left.\mathrm{CaCO}_{3}\right)\end{array}$ & $\begin{array}{c}\text { Dissolved } \\
\text { oxygen } \\
\text { (mg/L) }\end{array}$ & $\begin{array}{c}\text { Carbon } \\
\text { dioxide (Log- } \\
\mathrm{PCO}_{2} \text { ) } \\
\end{array}$ & $\begin{array}{l}\text { Aluminum } \\
(\mu \mathrm{g} / \mathrm{L})\end{array}$ & $\begin{array}{l}\text { Iron } \\
\text { ( } \mu \mathrm{g} / \mathrm{L})\end{array}$ \\
\hline \multicolumn{9}{|c|}{ Precipitation } \\
\hline \multicolumn{9}{|c|}{ Rain and snow } \\
\hline Craters of the Moon ${ }^{1}$ & 1980-2014 & 10 & 5.2 & 48 & 9 & -3.8 & nd & nd \\
\hline \multicolumn{9}{|c|}{ Snow } \\
\hline USGS 83 & 02-02-1978 & Frozen & 5.0 & nd & nd & -3.0 & nd & nd \\
\hline \multicolumn{9}{|c|}{ Surface water } \\
\hline Big Lost River near Arco & $06-05-1981$ & 13 & 8.1 & 164 & 8.8 & -2.9 & 10 & $<10$ \\
\hline $\begin{array}{l}\text { Big Lost River below INL } \\
\text { Diversion }\end{array}$ & 06-02-1995 & 15 & 8.4 & 108 & 7.2 & -3.4 & 10 & 11 \\
\hline $\begin{array}{l}\text { Little Lost River near } \\
\text { Howe }\end{array}$ & 06-28-1995 & 14.1 & 8.1 & 98 & $\approx 9.2$ & -2.9 & 30 & 39 \\
\hline Mud Lake near Terreton & 06-17-1995 & 14.7 & 8.5 & 103 & $\approx 8.4$ & -3.5 & 42 & 58 \\
\hline
\end{tabular}

\begin{tabular}{|c|c|c|c|c|c|c|c|c|}
\hline \multicolumn{9}{|c|}{ Tributary valley groundwater } \\
\hline \multicolumn{9}{|c|}{ Big Lost River Valley } \\
\hline Arco City Well 4 & 05-13-1997 & 9.6 & 8.0 & 175 & 6.3 & -2.8 & 1 & 43 \\
\hline Harrell & $07-31-2000$ & 10.5 & 7.4 & 213 & 8.3 & -2.1 & nd & $<10$ \\
\hline Mays & $06-26-2000$ & 15.0 & 7.9 & 128 & 7.1 & -2.8 & nd & $<10$ \\
\hline Nicholson & $07-31-2000$ & 11.0 & 7.6 & 184 & 7.2 & -2.4 & nd & 13 \\
\hline \multicolumn{9}{|c|}{ Birch Creek Valley } \\
\hline $\mathrm{P} \& W 2$ & 04-19-1995 & 9.5 & 8.2 & 140 & 9.7 & -3.1 & 5 & 38 \\
\hline USGS 126b & $11-08-2000$ & 10.5 & 8.2 & 133 & 10.3 & -3.1 & E10 & $<10$ \\
\hline \multicolumn{9}{|c|}{ Regional groundwater } \\
\hline ML 13 & $07-30-2008$ & 13.2 & 7.7 & 124 & 7.8 & -2.6 & nd & E5.7 \\
\hline ML 33 & $07-17-2002$ & 12.2 & 7.3 & 186 & 8.3 & -2.0 & nd & $<10$ \\
\hline ML 34 & 09-04-2001 & 16.4 & 7.6 & 157 & 7.8 & -2.4 & nd & $<10$ \\
\hline Reno Ranch & $06-28-2000$ & 14.0 & 7.6 & 190 & 6.4 & -2.3 & nd & $<10$ \\
\hline USGS 3A & $10-22-1952$ & 13.0 & 8.0 & 122 & nd & -2.9 & nd & 120 \\
\hline USGS 101 & $10-10-1996$ & 13.9 & 8.2 & 120 & 7.2 & -3.1 & 6 & 39 \\
\hline
\end{tabular}


Table 6. Measurements of field parameters, the calculated partial pressures of carbon dioxide, and concentrations of aluminum and iron, Idaho National Laboratory and vicinity, eastern Idaho.-Continued

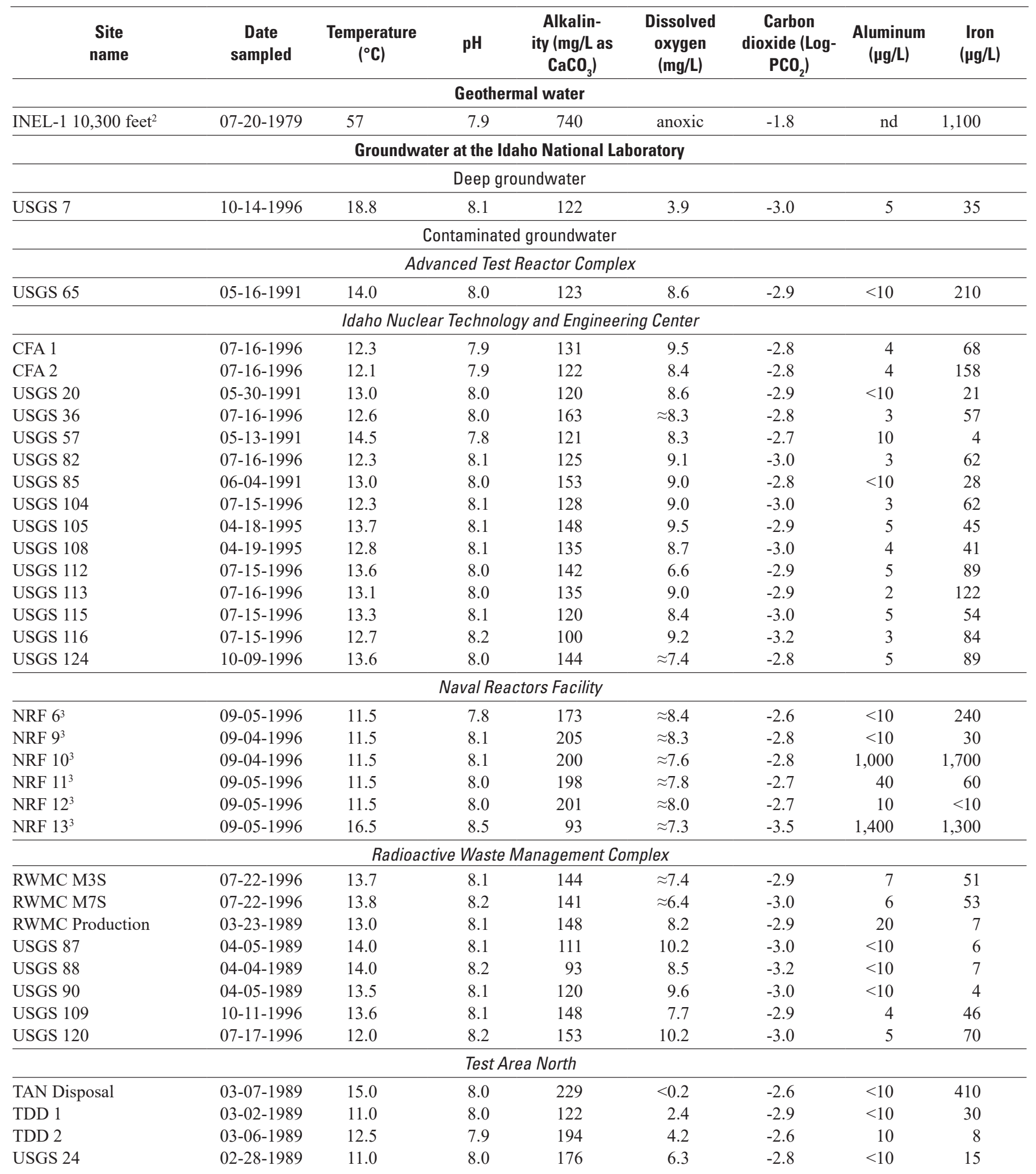


Table 6. Measurements of field parameters, the calculated partial pressures of carbon dioxide, and concentrations of aluminum and iron, Idaho National Laboratory and vicinity, eastern Idaho.-Continued

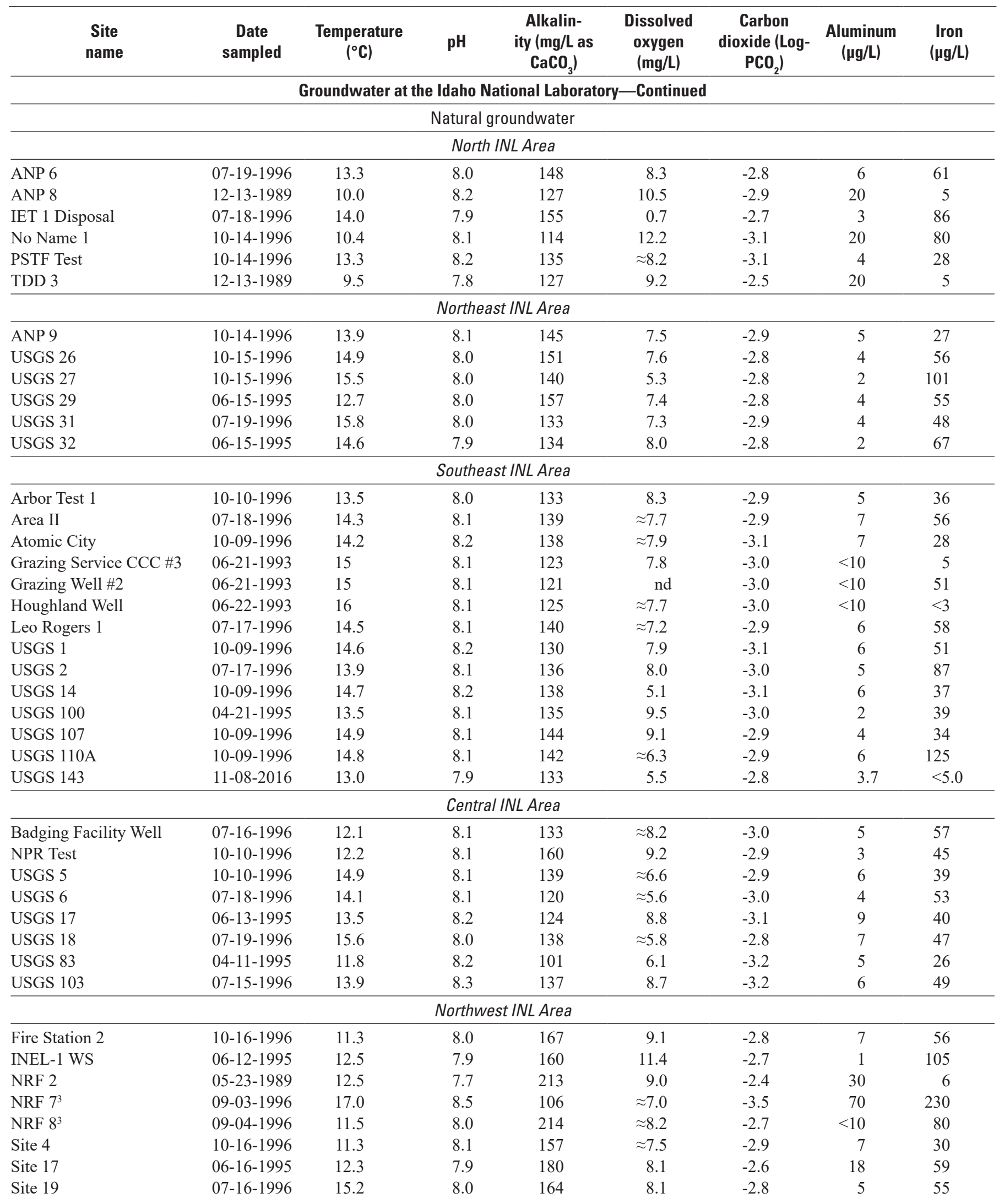


Table 6. Measurements of field parameters, the calculated partial pressures of carbon dioxide, and concentrations of aluminum and iron, Idaho National Laboratory and vicinity, eastern Idaho.-Continued

\begin{tabular}{|c|c|c|c|c|c|c|c|c|}
\hline $\begin{array}{c}\text { Site } \\
\text { name }\end{array}$ & $\begin{array}{c}\text { Date } \\
\text { sampled }\end{array}$ & $\begin{array}{c}\text { Temperature } \\
\left({ }^{\circ} \mathrm{C}\right)\end{array}$ & pH & $\begin{array}{c}\text { Alkalin- } \\
\text { ity (mg/L as } \\
\left.\mathrm{CaCO}_{3}\right)\end{array}$ & $\begin{array}{c}\text { Dissolved } \\
\text { oxygen } \\
\text { (mg/L) }\end{array}$ & $\begin{array}{c}\text { Carbon } \\
\text { dioxide (Log- } \\
\mathrm{PCO}_{2} \text { ) }\end{array}$ & $\begin{array}{c}\text { Aluminum } \\
(\mu \mathrm{g} / \mathrm{L})\end{array}$ & $\begin{array}{l}\text { Iron } \\
\text { ( } \mu \mathrm{g} / \mathrm{L} \text { ) }\end{array}$ \\
\hline \multicolumn{9}{|c|}{ Groundwater at the Idaho National Laboratory-Continued } \\
\hline \multicolumn{9}{|c|}{ Natural groundwater-Continued } \\
\hline \multicolumn{9}{|c|}{ Northwest INL Area-Continued } \\
\hline USGS 12 & 06-14-1995 & 12.0 & 7.8 & 214 & $\approx 8.0$ & -2.5 & 3 & 85 \\
\hline USGS 22 & 06-13-1995 & 20.0 & 7.9 & 71 & $\approx 2.2$ & -3.0 & 4 & 54 \\
\hline USGS 23 & 04-19-1995 & 15.4 & 7.9 & 149 & 7.5 & -2.7 & 5 & 54 \\
\hline USGS 97 & 06-13-1995 & 11.5 & 7.9 & 221 & 9.2 & -2.6 & 2 & 68 \\
\hline USGS 98 & 06-12-1995 & 12.3 & 8.0 & 171 & 10.1 & -2.8 & 2 & 50 \\
\hline USGS 99 & 06-12-1995 & 11.8 & 7.9 & 203 & 8.6 & -2.6 & 3 & 58 \\
\hline USGS 102 & 06-13-1995 & 11.6 & 7.9 & 217 & $\approx 8.3$ & -2.6 & 4 & 70 \\
\hline \multicolumn{9}{|c|}{ Southwest INL Area } \\
\hline Crossroads Well & $06-22-1993$ & 11 & 8.2 & 140 & $\approx 7.9$ & -3.1 & $<10$ & 12 \\
\hline Fingers Butte Well & 06-22-1993 & 15 & 8.3 & 121 & $\approx 7.9$ & -3.2 & $<10$ & $<3$ \\
\hline Highway $3^{4}$ & $10-12-1984$ & 14.7 & 8.3 & 151 & 9.2 & -3.1 & 27 & 97 \\
\hline Middle 2051 (sz) & $08-25-2008$ & 10.5 & 7.5 & 154 & 10.5 & -2.3 & 2 & $<8$ \\
\hline USGS 8 & 10-08-1996 & 11.4 & 8.0 & 165 & 8.0 & -2.8 & 6 & 45 \\
\hline USGS 9 & 10-11-1996 & 11.4 & 8.2 & 141 & 8.2 & -3.1 & 4 & 40 \\
\hline USGS 11 & 04-20-1995 & 11.7 & 8.1 & 142 & 8.2 & -3.0 & 6 & 42 \\
\hline USGS 86 & 10-11-1996 & 10.0 & 8.3 & 109 & 11.4 & -3.3 & 2 & 37 \\
\hline USGS 89 & 07-17-1996 & 13.1 & 8.6 & 84 & 11.6 & -3.7 & 3 & 63 \\
\hline USGS 117 & 07-17-1996 & 13.4 & 8.3 & 99 & 7.0 & -3.3 & 3 & 49 \\
\hline USGS 119 & 04-03-1989 & 15.0 & 8.3 & 94 & 8.4 & -3.3 & $<10$ & 6 \\
\hline
\end{tabular}

${ }^{1}$ Data from the National Atmospheric Deposition Program (http://nadp.slh.wisc.edu/data/sites/siteDetails.aspx?net=NTN\&id=ID03) and Busenberg and others (2001).

${ }^{2}$ Water was assumed to be anoxic based on the large iron concentration; lithium measurement was from sample collected from INEL-1 from interval $3,559-4,878$ feet below land surface.

${ }^{3}$ Total recoverable metals. Total recoverable concentrations of $\mathrm{Al}$ and Fe for natural groundwater (NRF 7 and NRF 8) probably exceed dissolved concentrations and may lead to a slight underestimate of the modeled precipitation of silicate minerals and goethite.

${ }^{4}$ Dissolved metals measured from sample collected April 29, 1997 (Johnson and others, 2000). 
Table 7. Concentrations of major ions, silica, and the charge balance for water-quality analyses from precipitation, surface water, and groundwater, Idaho National Laboratory and vicinity, eastern Idaho.

[Data from Busenberg and others (2000), Rattray (2015), Knobel and others (1992, 1999a, 1999b), U.S. Geological Survey National Water Information System (2017), Bartholomay and others (2001), Swanson and others (2002, 2003), Carkeet and others (2001), Bartholomay and Twining (2010), Bartholomay and others (2015), Rightmire and Lewis (1987), and Mann (1986). Location of sites shown on figures 1, 7, and 8. All concentrations are in millgrams per liter except nitrate (nitrite plus nitrate) which is milligrams per liter as nitrogen. Charge balance in \pm percent. Bicarbonate: Concentrations from Busenberg and others (2000), Knobel and others (1992), or were or calculated from alkalinity using the equation in Hem (1992). Abbreviations: INL, Idaho National Laboratory; sz, shallow zone; nd, not determined. Symbols: <, less than; (\#\#), parentheses were used to indicate a sulfate concentration reported for anoxic water]

\begin{tabular}{|c|c|c|c|c|c|c|c|c|c|c|c|}
\hline \multirow{2}{*}{$\begin{array}{c}\text { Site } \\
\text { name }\end{array}$} & \multicolumn{10}{|c|}{ Major ions } & \multirow{2}{*}{$\begin{array}{c}\text { Charge } \\
\text { balance }\end{array}$} \\
\hline & Calcium & Magnesium & Sodium & Potassium & Bicarbonate & Chloride & Sulfate & Fluoride & Nitrate & Silica & \\
\hline \multicolumn{12}{|c|}{ Precipitation } \\
\hline \multicolumn{12}{|c|}{ Rain and snow } \\
\hline Craters of the Moon ${ }^{1}$ & 0.248 & 0.028 & 0.191 & 0.031 & 0.53 & 0.268 & 0.472 & 0.010 & 0.145 & 0.08 & 0.0 \\
\hline \multicolumn{12}{|c|}{ Snow } \\
\hline USGS 22 & 0.8 & 0.1 & 0.1 & 0.8 & 2 & 0.3 & 2.3 & 0.1 & nd & 1.1 & -12.8 \\
\hline USGS 83 & 0.1 & 0.2 & 0.2 & 2.2 & 5 & 0.8 & 3.1 & 0.1 & nd & 1.5 & -33.7 \\
\hline \multicolumn{12}{|c|}{ Surface water } \\
\hline Big Lost River near Arco & 48 & 12 & 7.1 & 1.6 & 200 & 4.8 & 27 & 0.2 & 0.1 & 13 & -3.8 \\
\hline $\begin{array}{l}\text { Big Lost River below INL } \\
\text { Diversion }\end{array}$ & 35 & 8 & 5.4 & 1.4 & 126 & 3 & 18 & 0.2 & $<0.05$ & 12 & 1.7 \\
\hline $\begin{array}{l}\text { Big Lost River below lower } \\
\text { Lincoln Blvd Br }\end{array}$ & 31.2 & 7.4 & 4.8 & 1.7 & 123 & 3.1 & 17.5 & 0.21 & 0.2 & 10.7 & -1.7 \\
\hline Birch Creek at Blue Dome & 41.9 & 15.1 & 5.2 & 0.9 & 191 & 4.8 & 25.3 & 0.18 & 0.2 & 7.7 & -4.2 \\
\hline Little Lost River near Howe & 26.8 & 8.7 & 4.0 & 1.2 & 120 & 3.8 & 8.5 & 0.10 & 0.1 & 10.1 & -0.6 \\
\hline Mud Lake near Terreton & 28.4 & 6.5 & 5.2 & 2.1 & 125 & 2.5 & 4.3 & 0.12 & 0.3 & 14.7 & -1.2 \\
\hline \multicolumn{12}{|c|}{ Tributary valley groundwater } \\
\hline \multicolumn{12}{|c|}{ Big Lost River Valley } \\
\hline Arco City Well 4 & 53.5 & 13.5 & 5.4 & 1.0 & 209 & 6.5 & 19.9 & 0.20 & 0.6 & 13.4 & -0.8 \\
\hline \multicolumn{12}{|c|}{ Little Lost River Valley } \\
\hline Harrell & 63 & 22 & 17 & 1.3 & 259 & 21.6 & 34.4 & 0.16 & 1.9 & 19 & 0.0 \\
\hline Mays & 28 & 13 & 12 & 1.4 & 156 & 5.6 & 15.0 & 0.14 & 0.4 & 21 & -0.9 \\
\hline Nicholson & 85 & 45 & 27 & 1.8 & 225 & 143 & 60.3 & $<0.1$ & 4.2 & 23 & -0.7 \\
\hline Ruby Farms & 62 & 23 & 14 & 1.6 & 204 & 50 & 32 & $<0.1$ & 2.9 & 19 & -0.2 \\
\hline \multicolumn{12}{|c|}{ Birch Creek Valley } \\
\hline P\&W2 & 38.0 & 14.3 & 7.5 & 1.2 & 171 & 5.5 & 25.8 & 0.19 & 0.3 & 12.1 & -1.9 \\
\hline USGS $126 \mathrm{~b}$ & 38 & 15 & 8.7 & 2.3 & 162 & 8.2 & 29 & 0.23 & 0.5 & 18 & -0.1 \\
\hline \multicolumn{12}{|c|}{ Regional groundwater } \\
\hline ML 13 & 32.1 & 9.3 & 14.8 & 2.9 & 148 & 8.8 & 11.7 & 1.01 & 2.5 & 37 & -1.2 \\
\hline ML 22 & 68.9 & 26.0 & 37.9 & 6.8 & 340 & 40.4 & 31.9 & 0.21 & 4.9 & 28 & -2.4 \\
\hline ML 27 & 14.6 & 6.3 & 37.2 & 6.8 & 140 & 12.7 & 17.2 & 0.64 & 0.1 & 33 & -0.8 \\
\hline ML 29 & 19 & 17 & 23 & 4.3 & 181 & 10 & 9.8 & 0.50 & 0.1 & 29 & -1.5 \\
\hline ML 33 & 113 & 37.8 & 39.7 & 7.3 & 226 & 166 & 86.3 & 0.28 & 5.5 & 37.3 & 0.3 \\
\hline ML 34 & 41.9 & 15.1 & 40.0 & 3.4 & 192 & 24.1 & 59.4 & 0.54 & 1.5 & 35.6 & -0.5 \\
\hline Reno Ranch & 49 & 24 & 12 & 2.9 & 232 & 12.0 & 34.0 & 1.5 & 0.6 & 41 & 0.3 \\
\hline USGS 3A & 29.0 & 9.5 & 15 & 2.7 & 149 & 8.0 & 9.1 & 0.90 & 0.3 & 34.0 & 0.0 \\
\hline USGS 101 & 28.8 & 9.2 & 12.9 & 2.8 & 148 & 8.5 & 9.0 & 0.78 & 0.8 & 33.6 & -2.7 \\
\hline \multicolumn{12}{|c|}{ Geothermal water } \\
\hline INEL-1 10,300 feet & 7.3 & 0.5 & 390 & 7.5 & 900 & 12 & ${ }^{2}(99)$ & 13 & nd & 47 & -1.4 \\
\hline \multicolumn{12}{|c|}{ Groundwater at the Idaho National Laboratory } \\
\hline \multicolumn{12}{|c|}{ Deep groundwater } \\
\hline USGS 7 & 24.6 & 9.3 & 20.8 & 4.4 & 142 & 9.1 & 16.1 & 1.30 & 0.4 & 47.1 & -0.6 \\
\hline
\end{tabular}


Table 7. Concentrations of major ions, silica, and the charge balance for water-quality analyses from precipitation, surface water, and groundwater, Idaho National Laboratory and vicinity, eastern Idaho.-Continued

\begin{tabular}{|c|c|c|c|c|c|c|c|c|c|c|c|}
\hline \multirow{2}{*}{$\begin{array}{c}\text { Site } \\
\text { name }\end{array}$} & \multicolumn{10}{|c|}{ Major ions } & \multirow{2}{*}{$\begin{array}{l}\text { Charge } \\
\text { balance }\end{array}$} \\
\hline & Calcium & Magnesium & Sodium & Potassium & Bicarbonate & Chloride & Sulfate & Fluoride & Nitrate & Silica & \\
\hline \multicolumn{12}{|c|}{ Groundwater at the Idaho National Laboratory-Continued } \\
\hline \multicolumn{12}{|c|}{ Contaminated groundwater } \\
\hline \multicolumn{12}{|c|}{ Advanced Test Reactor Complex } \\
\hline USGS 65 & 85.0 & 19 & 14 & 3.0 & 150 & 21 & 150 & $<0.1$ & 1.6 & 21.0 & 1.4 \\
\hline \multicolumn{12}{|c|}{ Idaho Nuclear Technology and Engineering Center } \\
\hline CFA 1 & 61.6 & 18.6 & 14.4 & 3.2 & 160 & 74.0 & 27.7 & 0.25 & 3.5 & 20.9 & -2.3 \\
\hline CFA 2 & 71.9 & 26.4 & 21.4 & 4.3 & 149 & 115 & 45.0 & 0.39 & 3.7 & 23.6 & -0.9 \\
\hline USGS 20 & 41.0 & 12 & 8.0 & 2.6 & 146 & 21 & 22 & 0.20 & 1.0 & 23.0 & -1.4 \\
\hline USGS 36 & 60.9 & 15.4 & 16.7 & 2.8 & 199 & 33.9 & 27.7 & 0.22 & 1.8 & 19.3 & 1.4 \\
\hline USGS 57 & 67.0 & 18 & 41 & 3.6 & 148 & 110 & 35 & 0.30 & 3.7 & 23.0 & 1.1 \\
\hline USGS 82 & 35.7 & 13.4 & 10.4 & 3.0 & 152 & 18 & 21 & 0.21 & 0.5 & 22.6 & -1.4 \\
\hline USGS 85 & 57.0 & 14 & 22 & 2.9 & 187 & 46 & 31 & 0.20 & 2.5 & 21.0 & -1.9 \\
\hline USGS 104 & 34.9 & 13.7 & 7.6 & 2.4 & 156 & 12.6 & 19.3 & 0.20 & 0.7 & 24.7 & -2.1 \\
\hline USGS 105 & 40.8 & 15.2 & 12.7 & 2.8 & 180 & 13.6 & 26.0 & 0.19 & 0.7 & 21.2 & -0.7 \\
\hline USGS 108 & 37.0 & 15.0 & 10.6 & 2.4 & 165 & 14.0 & 22.4 & 0.24 & 0.7 & 23.3 & -0.7 \\
\hline USGS 112 & 76.0 & 21.0 & 54.0 & 4.9 & 173 & 151 & 29.0 & 0.26 & 3.2 & 21.5 & 0.2 \\
\hline USGS 113 & 78.3 & 23.1 & 78.4 & 6.2 & 164 & 218 & 31.2 & 0.15 & 2.4 & 21.5 & -1.6 \\
\hline USGS 115 & 42.9 & 13.3 & 13.2 & 3.3 & 146 & 38.0 & 21.2 & 0.23 & 1.3 & 21.5 & -1.8 \\
\hline USGS 116 & 56.4 & 16.0 & 24.8 & 4.6 & 122 & 89.3 & 34.2 & 0.30 & 3.0 & 22.2 & -1.5 \\
\hline USGS 124 & 38.6 & 16.2 & 8.8 & 2.4 & 176 & 14.8 & 21.5 & 0.30 & 0.7 & 25.7 & -1.8 \\
\hline \multicolumn{12}{|c|}{ Naval Reactors Facility } \\
\hline NRF 6 & 130 & 35 & 110 & 4.4 & 211 & 240 & 200 & 0.20 & 1.7 & $\approx 22$ & -0.9 \\
\hline NRF 9 & 73 & 24 & 17 & 2.4 & 250 & 48 & 49 & $\approx 0.30$ & 2.2 & $\approx 20$ & -1.9 \\
\hline NRF 10 & 72 & 25 & 16 & 2.4 & 244 & 43 & 44 & $\approx 0.30$ & 1.8 & $\approx 20$ & 0.8 \\
\hline NRF 11 & 72 & 23 & 19 & 2.8 & 241 & 44 & 50 & $\approx 0.30$ & 1.9 & $\approx 20$ & -0.1 \\
\hline NRF 12 & 72 & 25 & 21 & 2.5 & 245 & 59 & 59 & $\approx 0.30$ & 2.0 & $\approx 20$ & -3.3 \\
\hline NRF 13 & 64 & 19 & 62 & 4.2 & 113 & 60 & 73 & $\approx 0.20$ & 0.8 & $\approx 20$ & 18.8 \\
\hline \multicolumn{12}{|c|}{ Radioactive Waste Management Complex } \\
\hline RWMC M3S & 43.4 & 15 & 8.2 & 2.6 & 176 & 13.4 & 24.3 & 0.30 & 0.7 & 23.6 & -0.6 \\
\hline RWMC M7S & 39.6 & 14 & 7.8 & 2.7 & 172 & 11.9 & 22.2 & 0.20 & 0.7 & 23.5 & -2.4 \\
\hline RWMC Production & 45.0 & 15 & 9.0 & 2.8 & 180 & 13.0 & 27.0 & 0.20 & 0.7 & 28.0 & -0.3 \\
\hline USGS 87 & 40.0 & 14 & 12 & 3.0 & 135 & 13 & 26 & 0.20 & 0.7 & 28.0 & 7.8 \\
\hline USGS 88 & 33.0 & 23 & 47 & 7.0 & 113 & 82 & 64 & 0.30 & 1.8 & 30.0 & 0.8 \\
\hline USGS 90 & 44.0 & 15 & 9.4 & 2.7 & 146 & 13 & 27.0 & 0.20 & 0.7 & 27.0 & 6.8 \\
\hline USGS 109 & 39.8 & 15.7 & 10.5 & 2.7 & 181 & 14.0 & 25.0 & 0.23 & 0.6 & 24.4 & -2.1 \\
\hline USGS 120 & 34.0 & 18.4 & 25.4 & 4.0 & 186 & 21.7 & 38.0 & 0.26 & 0.8 & 22.4 & -1.6 \\
\hline \multicolumn{12}{|c|}{ Test Area North } \\
\hline TAN Disposal & 57 & 22 & 97 & 4.3 & 279 & 150 & ${ }^{2}(32)$ & 0.1 & $<0.1$ & 23 & -2.9 \\
\hline TDD 1 & 53 & 20 & 15 & 3.5 & 149 & 64 & 39 & 0.2 & 1.2 & 19 & -1.4 \\
\hline TDD 2 & 71 & 19 & 57 & 4.4 & 237 & 120 & 40 & 0.2 & 2.3 & 19 & -3.8 \\
\hline USGS 24 & 74.0 & 19 & 26 & 2.4 & 215 & 69 & 36 & 0.20 & 1.7 & 21.0 & 0.5 \\
\hline \multicolumn{12}{|c|}{ Natural groundwater } \\
\hline \multicolumn{12}{|c|}{ North INL } \\
\hline ANP 6 & 46.2 & 17.2 & 9.6 & 2.5 & 180 & 17.2 & 32.2 & 0.26 & 0.8 & 20.7 & -0.0 \\
\hline ANP 8 & 45.0 & 14 & 8.8 & 3.2 & 155 & 10 & 30 & 0.20 & 0.9 & 27.0 & 4.2 \\
\hline IET 1 Disposal & 49 & 13.9 & 15.9 & 3.6 & 189 & 18.7 & 29.9 & 0.21 & 1.4 & 18.8 & -0.1 \\
\hline No Name 1 & 34.0 & 15.2 & 10.0 & 3.5 & 139 & 19.9 & 24.2 & 0.29 & 0.6 & 25.7 & 0.7 \\
\hline PSTF Test & 30.4 & 14.9 & 6.5 & 2.4 & 164 & 6.6 & 14.4 & 0.21 & 0.6 & 23.7 & -2.8 \\
\hline TDD 3 & 51 & 15 & 7.4 & 3.1 & 155 & 12 & 33 & 0.2 & 0.9 & 23 & 6.7 \\
\hline
\end{tabular}


Table 7. Concentrations of major ions, silica, and the charge balance for water-quality analyses from precipitation, surface water, and groundwater, Idaho National Laboratory and vicinity, eastern Idaho.-Continued

\begin{tabular}{|c|c|c|c|c|c|c|c|c|c|c|c|}
\hline \multirow{2}{*}{$\begin{array}{c}\text { Site } \\
\text { name }\end{array}$} & \multicolumn{10}{|c|}{ Major ions } & \multirow{2}{*}{$\begin{array}{l}\text { Charge } \\
\text { balance }\end{array}$} \\
\hline & Calcium & Magnesium & Sodium & Potassium & Bicarbonate & Chloride & Sulfate & Fluoride & Nitrate & Silica & \\
\hline \multicolumn{12}{|c|}{ Groundwater at the Idaho National Laboratory-Continued } \\
\hline \multicolumn{12}{|c|}{ Natural groundwater-Continued } \\
\hline \multicolumn{12}{|c|}{ Northeast INL } \\
\hline ANP 9 & 38.1 & 15.7 & 13.7 & 2.9 & 177 & 12.6 & 29.1 & 0.39 & 0.7 & 30.6 & -1.3 \\
\hline USGS 26 & 41.2 & 14.9 & 13.2 & 3.5 & 182 & 13.3 & 28.6 & 0.43 & 0.8 & 32.7 & -1.4 \\
\hline USGS 27 & 54.0 & 19.1 & 24.0 & 6.4 & 170 & 61.9 & 38.5 & 0.58 & 2.4 & 37.2 & -0.8 \\
\hline USGS 29 & 48.5 & 14.1 & 19.0 & 3.4 & 192 & 26.0 & 16.7 & 0.43 & 2.0 & 28.2 & 0.8 \\
\hline USGS 31 & 41.0 & 15.3 & 14.4 & 3.9 & 172 & 22.5 & 27.7 & 0.41 & 0.8 & 30.9 & -1.3 \\
\hline USGS 32 & 49.5 & 18.7 & 17.7 & 4.2 & 163 & 42.0 & 39.1 & 0.38 & 1.4 & 28.9 & 0.8 \\
\hline \multicolumn{12}{|c|}{ Southeast INL } \\
\hline Arbor Test 1 & 34.9 & 11.5 & 14.4 & 3.1 & 162 & 14.5 & 12.4 & 0.64 & 1.2 & 34.0 & -1.0 \\
\hline Area II & 34.2 & 13.8 & 14.3 & 3.4 & 170 & 17.3 & 16.8 & 0.44 & 1.1 & 28.7 & -2.8 \\
\hline Atomic City & 34.1 & 13.4 & 14.7 & 3.4 & 168 & 17.2 & 16.1 & 0.49 & 1.1 & 31.4 & -2.5 \\
\hline Grazing Well \#2 & 29 & 12 & 15 & 3.1 & 148 & 12 & 14 & 0.6 & 0.9 & 33 & 0.2 \\
\hline Grazing Service CCC \#3 & 29 & 12 & 14 & 3.1 & 150 & 13 & 16 & 0.6 & 0.8 & 31 & -1.9 \\
\hline Houghland Well & 30 & 15 & 14 & 3.3 & 152 & 14 & 19 & 0.5 & 0.7 & 32 & 1.0 \\
\hline Leo Rogers 1 & 39.6 & 14.3 & 17.0 & 3.2 & 171 & 18.8 & 18.1 & 0.44 & 1.1 & 27.0 & 1.7 \\
\hline USGS 1 & 31.2 & 11.9 & 13.5 & 3.2 & 158 & 13.0 & 13.0 & 0.57 & 0.9 & 32.5 & -2.3 \\
\hline USGS 2 & 35.4 & 12.1 & 15.1 & 3.3 & 166 & 17.0 & 14.1 & 0.57 & 1.2 & 28.7 & -1.9 \\
\hline USGS 14 & 36.9 & 15.3 & 15.5 & 2.8 & 168 & 21.0 & 21.5 & 0.79 & 1.1 & 30.4 & -1.3 \\
\hline USGS 100 & 38.3 & 12.3 & 16.0 & 3.1 & 164 & 17.7 & 21.0 & 0.57 & 1.5 & 28.2 & -1.2 \\
\hline USGS 107 & 37.6 & 16.6 & 15.4 & 3.5 & 176 & 21.3 & 25.3 & 0.34 & 1.0 & 29.7 & -1.7 \\
\hline USGS 110A & 36.7 & 14.9 & 15.2 & 3.6 & 173 & 19.0 & 18.0 & 0.45 & 1.1 & 31.7 & -0.9 \\
\hline USGS 143 & 38.1 & 11.0 & 17.2 & 3.1 & 162 & 13.7 & 15.1 & 0.82 & 2.9 & 35.7 & 0.4 \\
\hline \multicolumn{12}{|c|}{ Central INL } \\
\hline Badging Facility Well & 37.9 & 14.1 & 9.7 & 2.3 & 162 & 16.9 & 21.4 & 0.22 & 0.7 & 24.4 & -1.8 \\
\hline NPR Test & 49.1 & 14.1 & 7.2 & 2.1 & 195 & 13.6 & 20.9 & 0.22 & 0.7 & 22.7 & -1.6 \\
\hline USGS 5 & 39.8 & 12.6 & 7.1 & 2.0 & 171 & 9.4 & 18.7 & 0.21 & 0.5 & 23.1 & -2.2 \\
\hline USGS 6 & 28.7 & 11.3 & 11.7 & 2.4 & 146 & 9.4 & 18.1 & 0.23 & 0.3 & 24.9 & -2.7 \\
\hline USGS 17 & 37.4 & 10.1 & 6.9 & 2.3 & 151 & 4.9 & 19.1 & 0.21 & 0.3 & 21.8 & -0.4 \\
\hline USGS 18 & 35.1 & 15.8 & 12.1 & 2.9 & 168 & 10.2 & 24.7 & 0.30 & 0.4 & 25.8 & 0.3 \\
\hline USGS 83 & 27.3 & 10.6 & 9.7 & 2.5 & 123 & 10.8 & 20.1 & 0.24 & 0.7 & 25.5 & -1.9 \\
\hline USGS 103 & 36.1 & 15.3 & 12.6 & 3.0 & 167 & 16.3 & 23.1 & 0.32 & 0.7 & 24.3 & -1.5 \\
\hline \multicolumn{12}{|c|}{ Northwest INL } \\
\hline Fire Station 2 & 54.8 & 17.8 & 8.1 & 2.4 & 204 & 17.6 & 23.5 & 0.19 & 1.2 & 22.7 & 1.8 \\
\hline INEL-1 WS & 67.5 & 27.4 & 14.5 & 2.6 & 195 & 66.6 & 40.4 & 0.12 & 3.6 & 20.9 & 0.9 \\
\hline NRF 2 & 70 & 22 & 18 & 1.8 & 260 & 46 & 39 & 0.30 & 1.7 & 22.0 & -3.1 \\
\hline NRF 7 & 24 & 9.0 & 10 & 2.8 & 122 & 5.2 & 14 & $\approx 0.30$ & 0.5 & $\approx 20$ & nd \\
\hline NRF 8 & 71 & 24 & 14 & 2.2 & 261 & 35 & 35 & $\approx 0.30$ & 2 & $\approx 20$ & nd \\
\hline Site 4 & 45.3 & 14.1 & 7.8 & 1.8 & 192 & 10.1 & 19.4 & 0.20 & 0.6 & 22.5 & -1.5 \\
\hline Site 17 & 51.0 & 17.3 & 9.8 & 1.3 & 219 & 9.9 & 20.4 & 0.12 & 1.0 & 14.5 & 0.4 \\
\hline Site 19 & 42.4 & 17.5 & 8.0 & 1.9 & 200 & 11.6 & 20.7 & 0.19 & 0.9 & 18.8 & -2.3 \\
\hline USGS 12 & 71.1 & 23.3 & 15.9 & 2.2 & 261 & 37.6 & 37.0 & 0.13 & 2.3 & 18.2 & -0.7 \\
\hline USGS 19 & 44.1 & 16.9 & 10.5 & 1.5 & 197 & 9.9 & 20.6 & 0.21 & 0.8 & 14.9 & 0.7 \\
\hline USGS 22 & 34.7 & 10.6 & 21.0 & 5.6 & 87 & 66.5 & 21.0 & 0.17 & 0.4 & 17.9 & -1.7 \\
\hline USGS 23 & 37.4 & 15.8 & 9.2 & 1.6 & 182 & 9.9 & 17.6 & 0.21 & 0.6 & 16.1 & -1.3 \\
\hline USGS 97 & 73.0 & 24.3 & 15.4 & 2.2 & 269 & 38.0 & 35.9 & 0.20 & 2.2 & 18.2 & -0.4 \\
\hline USGS 98 & 48.9 & 18.3 & 10.0 & 2.3 & 209 & 15.2 & 21.7 & 0.12 & 1.1 & 20.9 & 0.2 \\
\hline USGS 99 & 59.8 & 22.6 & 12.2 & 1.7 & 247 & 22.2 & 27.0 & 0.15 & 1.5 & 16.2 & 0.3 \\
\hline USGS 102 & 73.9 & 23.2 & 13.5 & 2.2 & 264 & 34.0 & 35.5 & 0.13 & 2.1 & 18.2 & 0.3 \\
\hline USGS 134 (sz) & 24.8 & 16 & 7.2 & 2.2 & 156 & 9.6 & 20.7 & 0.21 & 0.6 & 27 & -6.5 \\
\hline USGS 146 & 26.5 & 21.1 & 17.5 & 4.2 & 146 & 18.5 & 33.0 & 0.32 & 0.6 & 43.5 & 3.5 \\
\hline
\end{tabular}


Table 7. Concentrations of major ions, silica, and the charge balance for water-quality analyses from precipitation, surface water, and groundwater, Idaho National Laboratory and vicinity, eastern Idaho.-Continued

\begin{tabular}{|c|c|c|c|c|c|c|c|c|c|c|c|}
\hline \multirow{2}{*}{$\begin{array}{c}\text { Site } \\
\text { name }\end{array}$} & \multicolumn{10}{|c|}{ Major ions } & \multirow{2}{*}{$\begin{array}{l}\text { Charge } \\
\text { balance }\end{array}$} \\
\hline & Calcium & Magnesium & Sodium & Potassium & Bicarbonate & Chloride & Sulfate & Fluoride & Nitrate & Silica & \\
\hline \multicolumn{12}{|c|}{ Groundwater at the Idaho National Laboratory-Continued } \\
\hline \multicolumn{12}{|c|}{ Natural groundwater-Continued } \\
\hline \multicolumn{12}{|c|}{ Southwest INL } \\
\hline Crossroads Well & 41 & 14 & 7.3 & 2.2 & 171 & 9 & 21 & 0.2 & 0.7 & 23 & 0.2 \\
\hline Fingers Butte Well & 33 & 12 & 8.6 & 2.1 & 148 & 9.8 & 19 & 0.3 & 0.6 & 23 & -1.5 \\
\hline Highway 3 & 50 & 12 & 6.2 & 2.2 & 184 & 6.3 & 20 & 0.2 & 0.3 & 26 & 1.5 \\
\hline Middle 2051 (sz) & 46.3 & 11.1 & 5.7 & 2.4 & 188 & 5.7 & 22.0 & 0.25 & 0.4 & 24.3 & -3.0 \\
\hline USGS 8 & 46.8 & 15.0 & 6.9 & 1.8 & 201 & 8.4 & 21.0 & 0.20 & 0.9 & 18.9 & -1.9 \\
\hline USGS 9 & 40.7 & 15.6 & 12.2 & 3.5 & 172 & 20.9 & 26.0 & 0.20 & 0.7 & 23.1 & -1.4 \\
\hline USGS 11 & 41.2 & 14.2 & 8.2 & 2.1 & 173 & 11.8 & 23.1 & 0.19 & 0.6 & 19.2 & -1.3 \\
\hline USGS 86 & 37.0 & 10.2 & 11.0 & 2.9 & 132 & 19.6 & 22.7 & 0.16 & 1.4 & 25.5 & -1.4 \\
\hline USGS 89 & 27.2 & 15.6 & 17.9 & 3.7 & 95 & 38.8 & 34.9 & 0.33 & 1.8 & 24.7 & -0.9 \\
\hline USGS 117 & 25.7 & 11.2 & 9.6 & 2.6 & 121 & 13.7 & 17.1 & 0.22 & 0.6 & 27.7 & -2.3 \\
\hline USGS $119^{3}$ & 30.0 & 10.0 & 11.0 & 2.6 & 116 & 12.0 & 35.0 & 0.50 & 1.3 & 31.0 & -4.3 \\
\hline USGS 125 & 40.8 & 15.9 & 11.8 & 2.7 & 178 & 14.9 & 25.8 & 0.21 & 0.6 & 21.6 & -0.4 \\
\hline USGS 135 (sz) & 43.0 & 11.9 & 7.0 & 1.7 & 166 & 7.6 & 20.3 & 0.25 & 0.8 & 19.0 & 0.4 \\
\hline
\end{tabular}

${ }^{1}$ Concentration data are average annual concentrations for 1980 through 2014 reported by the National Atmospheric Deposition Program (http://nadp.slh. wisc.edu/data/sites/siteDetails.aspx?net=NTN\&id=ID03) except for concentrations of fluoride (Busenberg and others, 2001) and silica (Wood and Low, 1988). Bicarbonate was not measured, but a bicarbonate concentration was calculated that achieved a near-neutral charge balance for the ions.

${ }^{2}$ The sulfur in these reported sulfate concentrations would be in a reduced state in these anoxic waters.

${ }^{3}$ Data from sample collected in September 1990. 
Table 8. Measurements of the stable isotope ratios of hydrogen, oxygen, and carbon and the activity of tritium, Idaho National Laboratory and vicinity, eastern Idaho.

[Data from Busenberg and others (2000, 2001); Rattray (2015); Knobel and others (1992, 1999a, 1999b); U.S. Geological Survey National Water Information System (2017); Bartholomay and others (2001); Swanson and others (2002, 2003); Carkeet and others (2001); Benjamin and others (2004); Bartholomay and Twining (2010); and Bartholomay and others (2015). Location of sites shown on figures 1, 7, and 8. Date sampled: If tritium data are present, date represents the date that the tritium sample was collected. Abbreviations: BLR, Big Lost River; INL, Idaho National Laboratory; nd, not determined. sz, shallow zone. Units: \%o, permil; pCi/L, picocuries per liter. Symbols: $\delta^{2} \mathrm{H}, \delta^{18} \mathrm{O}$, and $\delta^{13} \mathrm{C}$, delta notation for the stable isotope ratios of hydrogen, oxygen, and carbon; \pm , plus or minus the indicated standard deviation (standard deviations are 1 sigma); nd, not determined; $\approx$, estimated value]

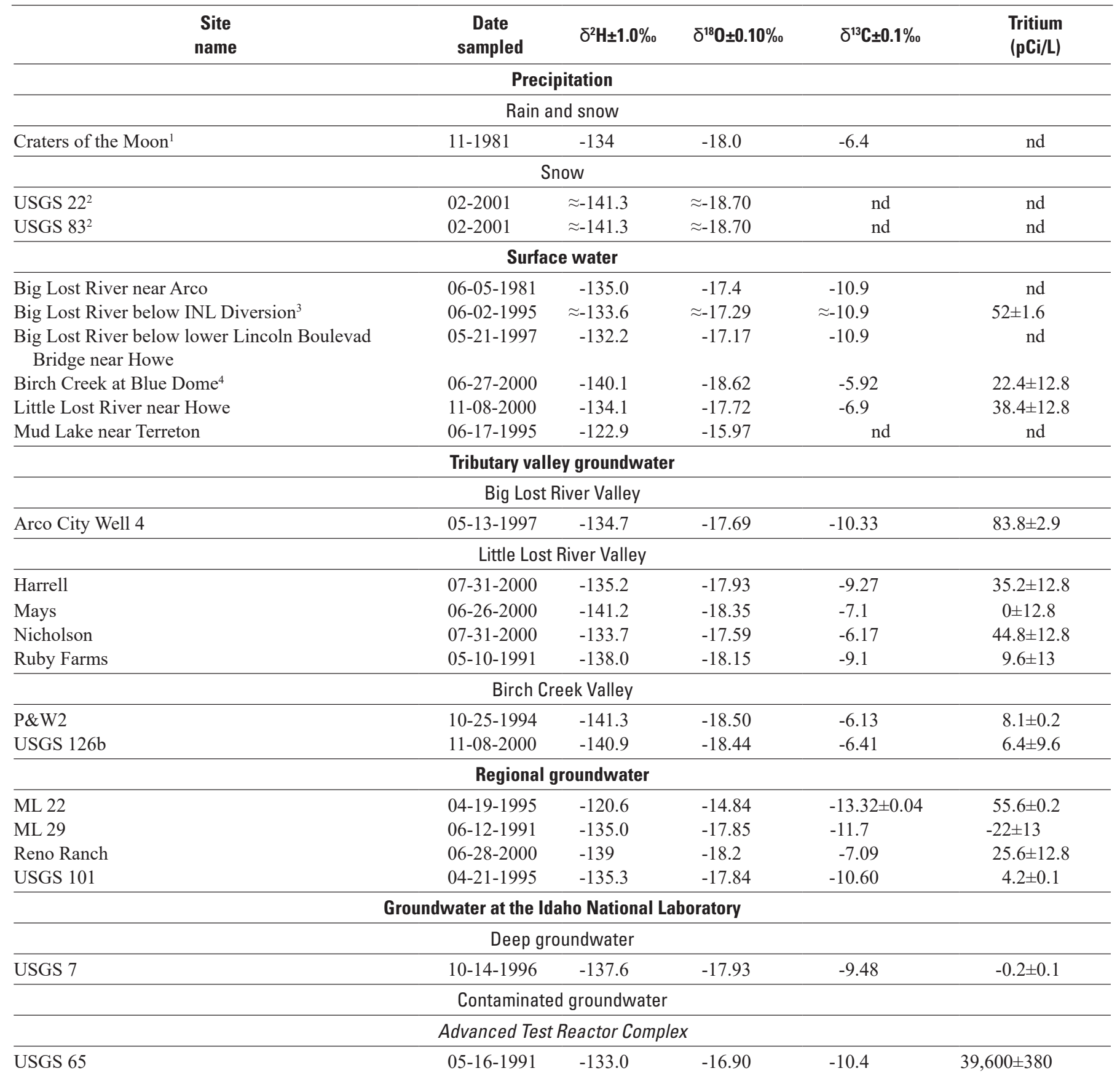


Table 8. Measurements of the stable isotope ratios of hydrogen, oxygen, and carbon and the activity of tritium, Idaho National Laboratory and vicinity, eastern Idaho.-Continued

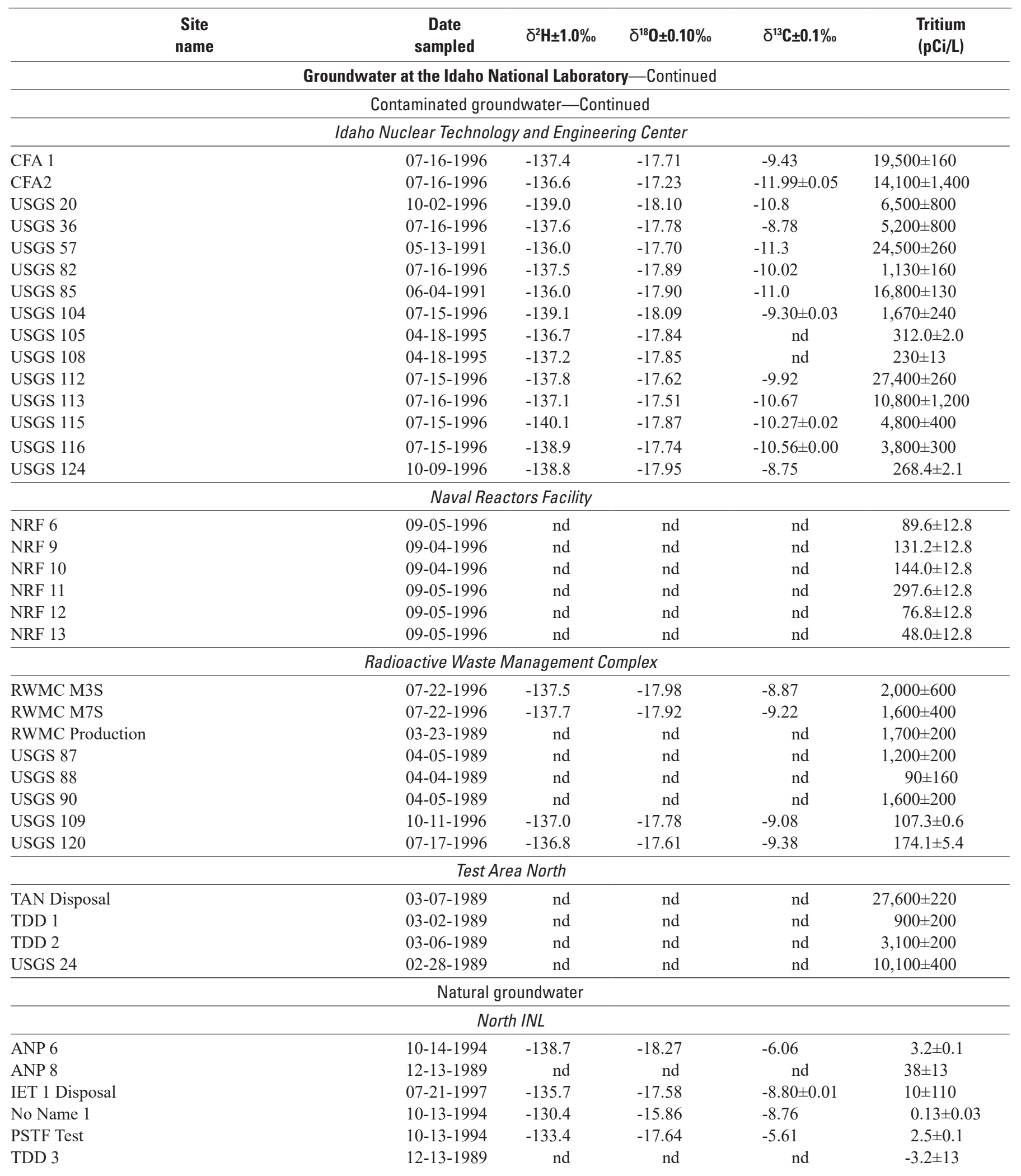


Table 8. Measurements of the stable isotope ratios of hydrogen, oxygen, and carbon and the activity of tritium, Idaho National Laboratory and vicinity, eastern Idaho.-Continued

\begin{tabular}{|c|c|c|c|c|c|}
\hline $\begin{array}{c}\text { Site } \\
\text { name }\end{array}$ & $\begin{array}{c}\text { Date } \\
\text { sampled }\end{array}$ & $\delta^{2} \mathrm{H} \pm 1.0 \%$ & $\delta^{18} 0 \pm 0.10 \%$ & $\delta^{13} \mathrm{C} \pm 0.1 \%$ & $\begin{array}{l}\text { Tritium } \\
\text { (pCi/L) }\end{array}$ \\
\hline \multicolumn{6}{|c|}{ Groundwater at the Idaho National Laboratory-Continued } \\
\hline \multicolumn{6}{|c|}{ Northeast INL } \\
\hline ANP 9 & 10-14-1994 & -137.9 & -17.88 & $-8.21 \pm 0.07$ & $0.2 \pm 0.2$ \\
\hline USGS 29 & 06-15-1995 & -134.5 & -17.67 & -11.75 & $22.7 \pm 0.4$ \\
\hline USGS 31 & 07-19-1996 & -135.9 & -17.81 & -9.39 & $-1.6 \pm 0.8$ \\
\hline USGS 32 & 10-11-1994 & -135.4 & -17.68 & -9.47 & $1.2 \pm 0.1$ \\
\hline \multicolumn{6}{|c|}{ Southeast INL } \\
\hline Arbor Test 1 & 04-21-1995 & -133.6 & -17.74 & $-11.21 \pm 0.01$ & $12.5 \pm 0.1$ \\
\hline Houghland Well & $06-22-1993$ & -136 & -18 & nd & $1.6 \pm 0.3$ \\
\hline Leo Rogers 1 & 07-17-1996 & -134.7 & -17.62 & $-10.59 \pm 0.02$ & $12.5 \pm 1.3$ \\
\hline USGS 1 & 10-09-1996 & -136.2 & -17.82 & $-10.71 \pm 0.00$ & $5.8 \pm 1.0$ \\
\hline USGS 2 & 07-17-1996 & -135.0 & -17.71 & $-11.67 \pm 0.02$ & $12.2 \pm 1.3$ \\
\hline USGS 14 & 10-26-1994 & -135.5 & -17.61 & $-9.29 \pm 0.00$ & $19.2 \pm 0.1$ \\
\hline USGS 100 & 04-21-1995 & -133.8 & -17.78 & -11.17 & $14.0 \pm 0.3$ \\
\hline USGS 107 & 10-09-1996 & -134.3 & -17.55 & $-9.21 \pm 0.05$ & $10.2 \pm 1.0$ \\
\hline USGS 110A & 10-09-1996 & -134.4 & -17.64 & $-10.64 \pm 0.01$ & $10.9 \pm 1.0$ \\
\hline USGS 143 & 11-08-2016 & -134.0 & -17.56 & -12.06 & $17.1 \pm 2.1$ \\
\hline \multicolumn{6}{|c|}{ Central INL } \\
\hline \multicolumn{6}{|c|}{ Northwest INL } \\
\hline Fire Station 2 & $10-16-1996$ & -138.7 & -17.94 & -9.32 & $36.5 \pm 1.6$ \\
\hline INEL-1 WS & 06-12-1995 & -138.6 & -17.97 & -8.88 & $48.3 \pm 1.9$ \\
\hline NRF 7 & $11-01-2001$ & nd & nd & nd & $1.2 \pm 1.1$ \\
\hline NRF 8 & 09-04-1996 & nd & nd & nd & $57.6 \pm 12.8$ \\
\hline Site 4 & 10-16-1996 & -137.9 & -17.74 & -10.19 & $51.5 \pm 1.9$ \\
\hline Site 17 & 04-11-2017 & -138.9 & -18.10 & -8.48 & $7.7 \pm 1.7$ \\
\hline Site 19 & 07-16-1996 & -139.0 & -18.04 & -8.35 & $13.4 \pm 1.0$ \\
\hline USGS 12 & 06-14-1995 & -135.0 & -17.47 & -10.18 & $71.9 \pm 0.7$ \\
\hline USGS 19 & 04-19-1995 & -138.1 & -18.07 & $-7.06 \pm 0.03$ & $11.8 \pm 0.3$ \\
\hline USGS 22 & 06-13-1995 & -136.8 & -17.62 & -13.55 & $160.9 \pm 0.4$ \\
\hline USGS 23 & 04-19-1995 & -138.1 & -17.94 & -5.72 & $1.3 \pm 0.1$ \\
\hline USGS 97 & 06-13-1995 & -137.1 & -17.55 & -10.09 & $69.0 \pm 1.0$ \\
\hline USGS 98 & 10-04-1994 & -137.6 & -18.07 & -8.84 & $20.0 \pm 0.4$ \\
\hline USGS 99 & 06-12-1995 & -136.8 & -17.99 & -9.68 & $36.2 \pm 0.5$ \\
\hline USGS 102 & 06-13-1995 & -135.3 & -17.50 & -9.81 & $70.8 \pm 0.6$ \\
\hline USGS 134 (sz) & 09-04-2008 & -137.0 & -18.1 & -8.48 & $17 \pm 1.9$ \\
\hline USGS 146 & $10-25-2017$ & -138.7 & -18.17 & nd & $0.16 \pm 2.0$ \\
\hline
\end{tabular}


Table 8. Measurements of the stable isotope ratios of hydrogen, oxygen, and carbon and the activity of tritium, Idaho National Laboratory and vicinity, eastern Idaho._-Continued

\begin{tabular}{|c|c|c|c|c|c|}
\hline $\begin{array}{c}\text { Site } \\
\text { name }\end{array}$ & $\begin{array}{c}\text { Date } \\
\text { sampled }\end{array}$ & $\delta^{2} \mathrm{H} \pm 1.0 \%$ & $\delta^{18} 0 \pm 0.10 \%$ & $\delta^{13} \mathrm{C} \pm 0.1 \%$ & $\begin{array}{l}\text { Tritium } \\
\text { (pCi/L) }\end{array}$ \\
\hline \multicolumn{6}{|c|}{ Groundwater at the Idaho National Laboratory-Continued } \\
\hline \multicolumn{6}{|c|}{ Southwest INL } \\
\hline Crossroads Well & $06-22-1993$ & -138 & -18.23 & nd & $17 \pm 0.6$ \\
\hline Middle 2051 (sz) & $08-25-2008$ & -134.1 & -17.3 & -10.7 & $51.7 \pm 2.9$ \\
\hline USGS 8 & 10-04-1994 & -135.7 & -17.78 & $-9.41 \pm 0.00$ & $47.4 \pm 0.5$ \\
\hline USGS 9 & 10-04-1994 & -136.2 & -17.75 & -9.51 & $47.9 \pm 0.2$ \\
\hline USGS 11 & 04-20-1995 & -138.6 & -17.92 & $-9.17 \pm 0.03$ & $31.8 \pm 0.2$ \\
\hline USGS 86 & 10-11-1996 & -139.4 & -18.13 & $-8.90 \pm 0.01$ & $2.9 \pm 1.0$ \\
\hline USGS 135 (sz) & 09-14-2010 & -137.0 & -17.92 & -9.06 & $14 \pm 1.9$ \\
\hline
\end{tabular}

${ }^{1}$ Includes $\delta^{2} \mathrm{H}$ and $\delta^{18} \mathrm{O}$ data from U.S. Geological Survey National Water Information System (2017) and $\delta^{13} \mathrm{C}$ value from Clark and Fritz (1997).

${ }^{2}$ Stable isotope data from snow core collected at site BLR below INL Diversion (Benjamin and others, 2004).

${ }^{3} \delta^{2} \mathrm{H}, \delta^{18} \mathrm{O}$, and $\delta^{13} \mathrm{C}$ values estimated as mean of values from BLR near Arco and BLR below lower Lincoln Boulevard Bridge near Howe.

${ }^{4} \delta^{13} \mathrm{C}$ value from Birch Creek at Kaufman Guard Station (Rattray, 2018). 


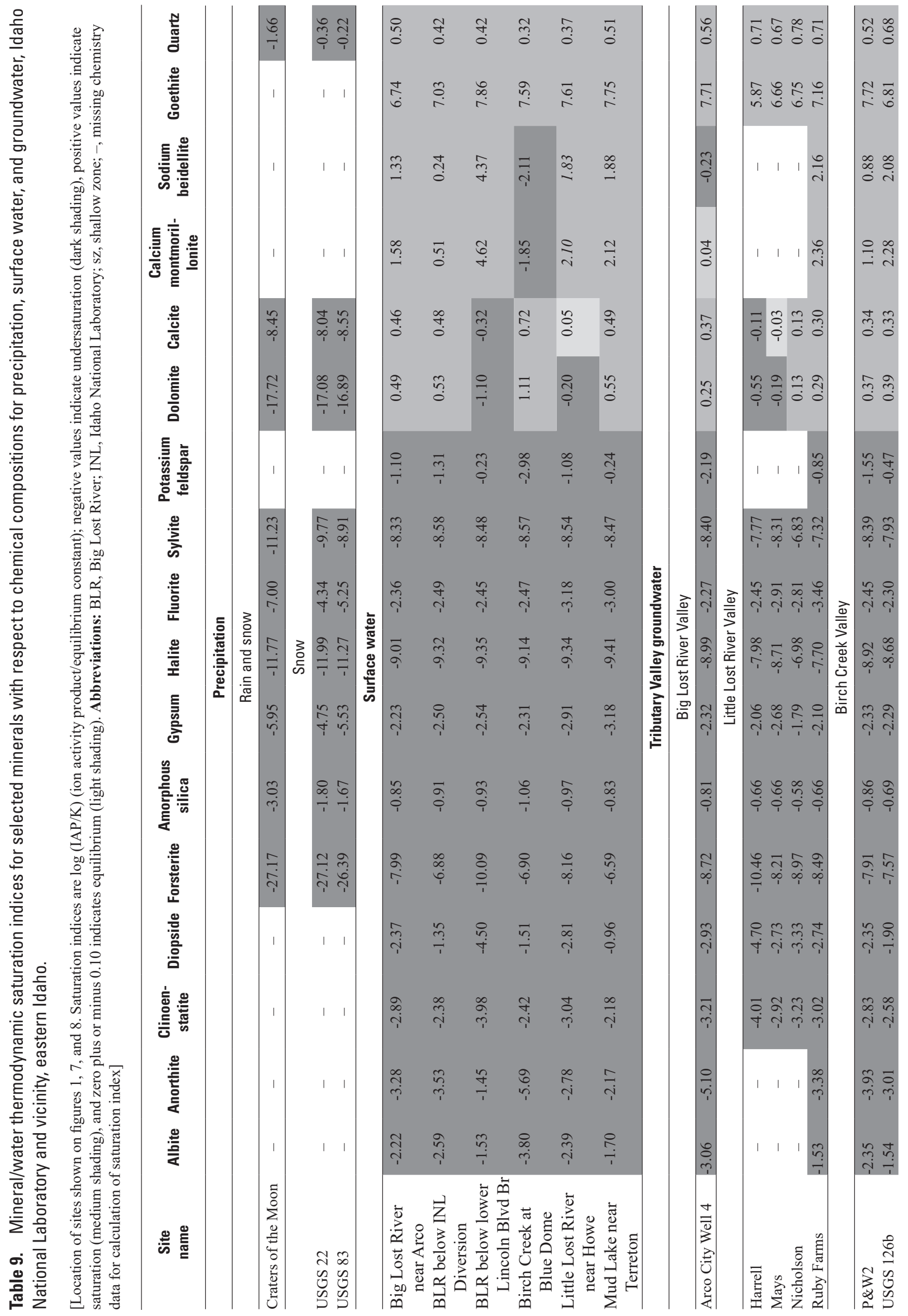




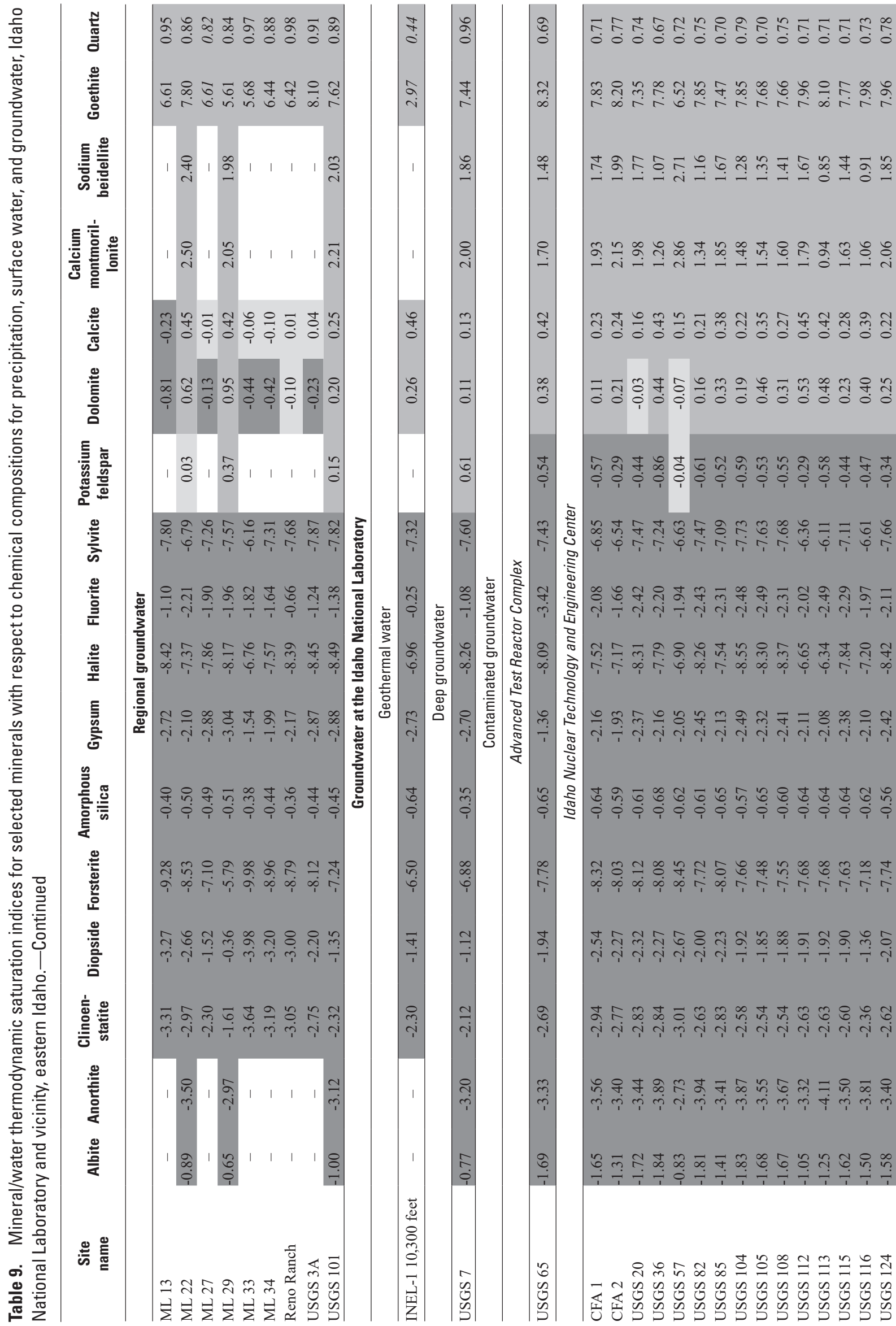



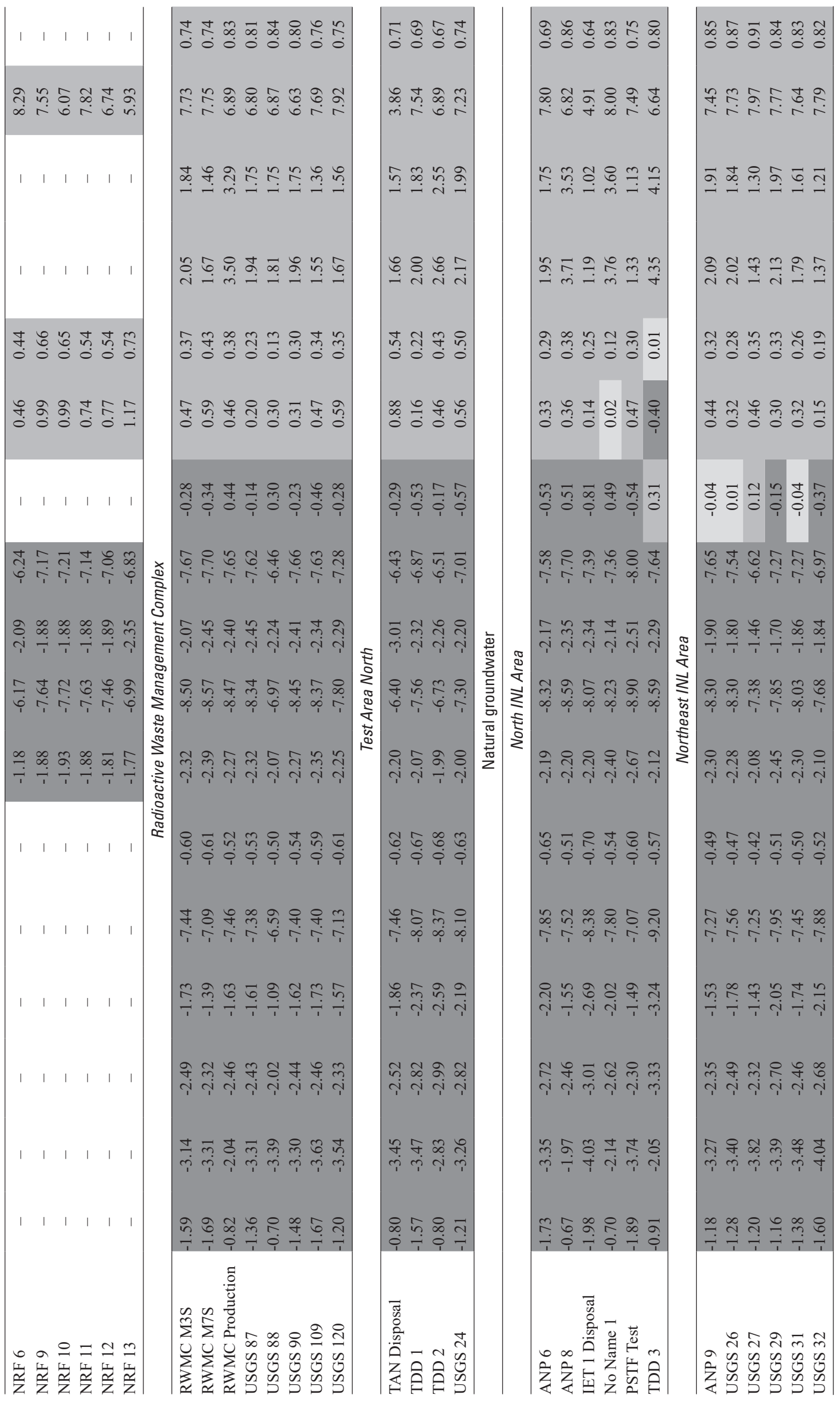
Tables 6-11

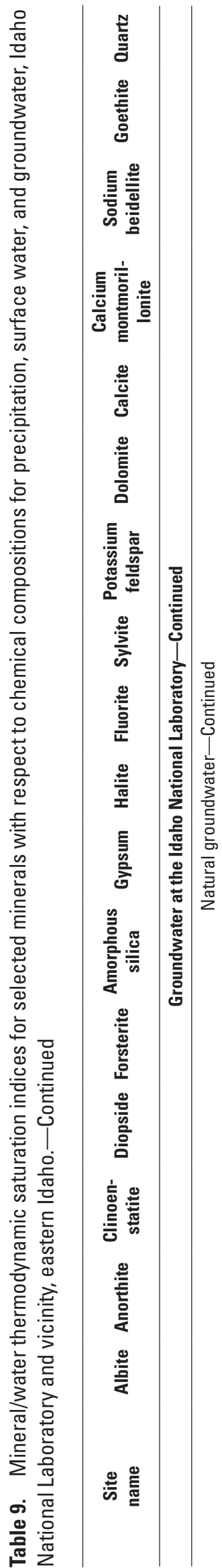

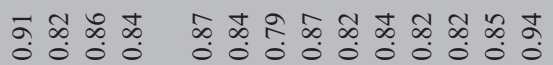

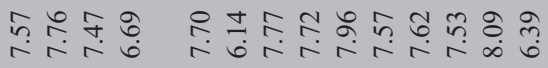

थู่

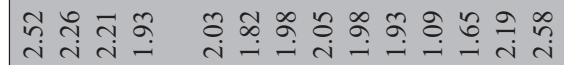

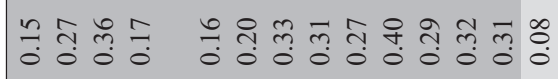

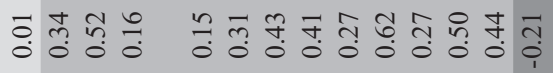

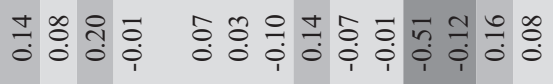

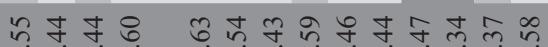

14

舟英章

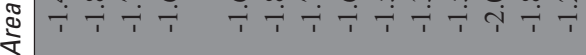

สี

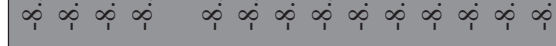

象 的的

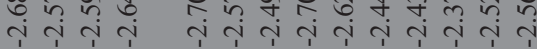

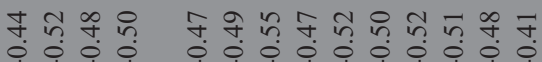

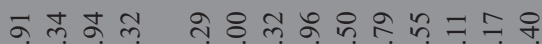

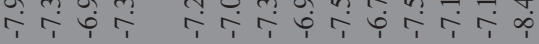

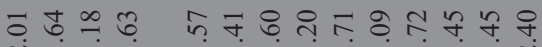

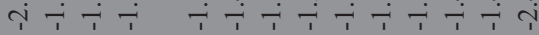

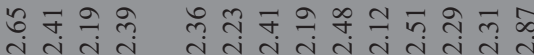

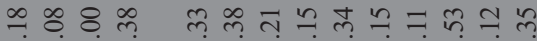

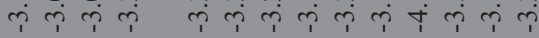

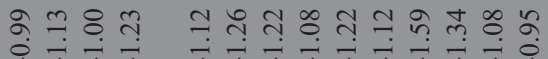

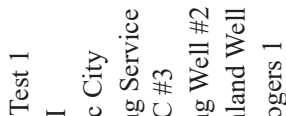

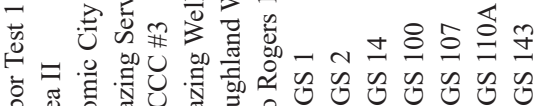

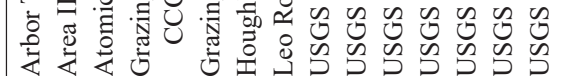

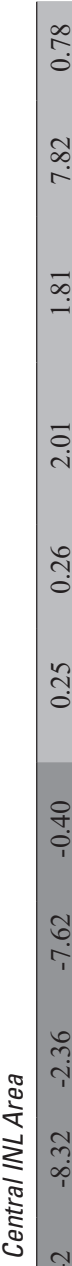

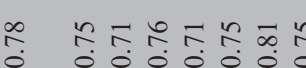

至

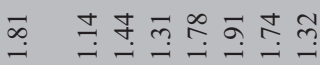

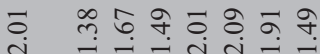

ก̊.

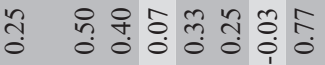

앙 는

20ำ

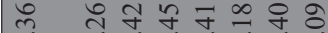
₹

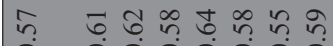

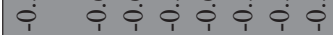

$\infty$ 중

T

- దำ

$\div \quad \div \div \div \div$

की

त.

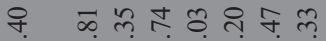

ก

กำ

昰

要

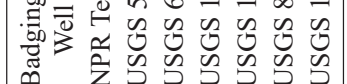

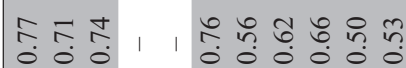

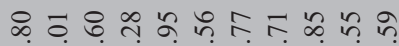

r,

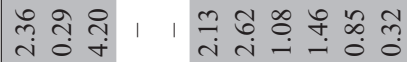

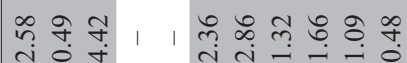

䑻

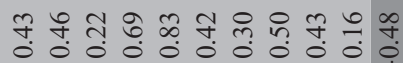

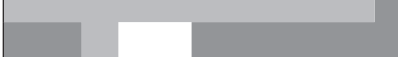

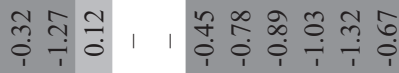

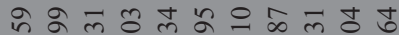

रे

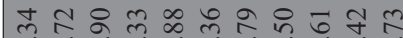
ฮง k

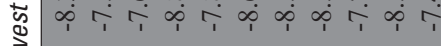

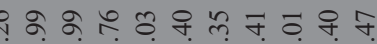

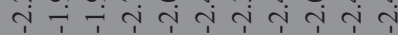

우유.

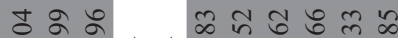

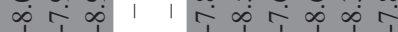

సู่

4⿻𨈑㇒𠃋

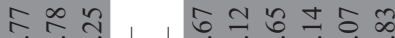

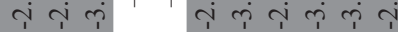

పำㄴ,

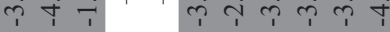

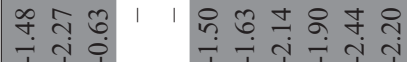

กี

焉

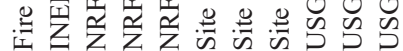




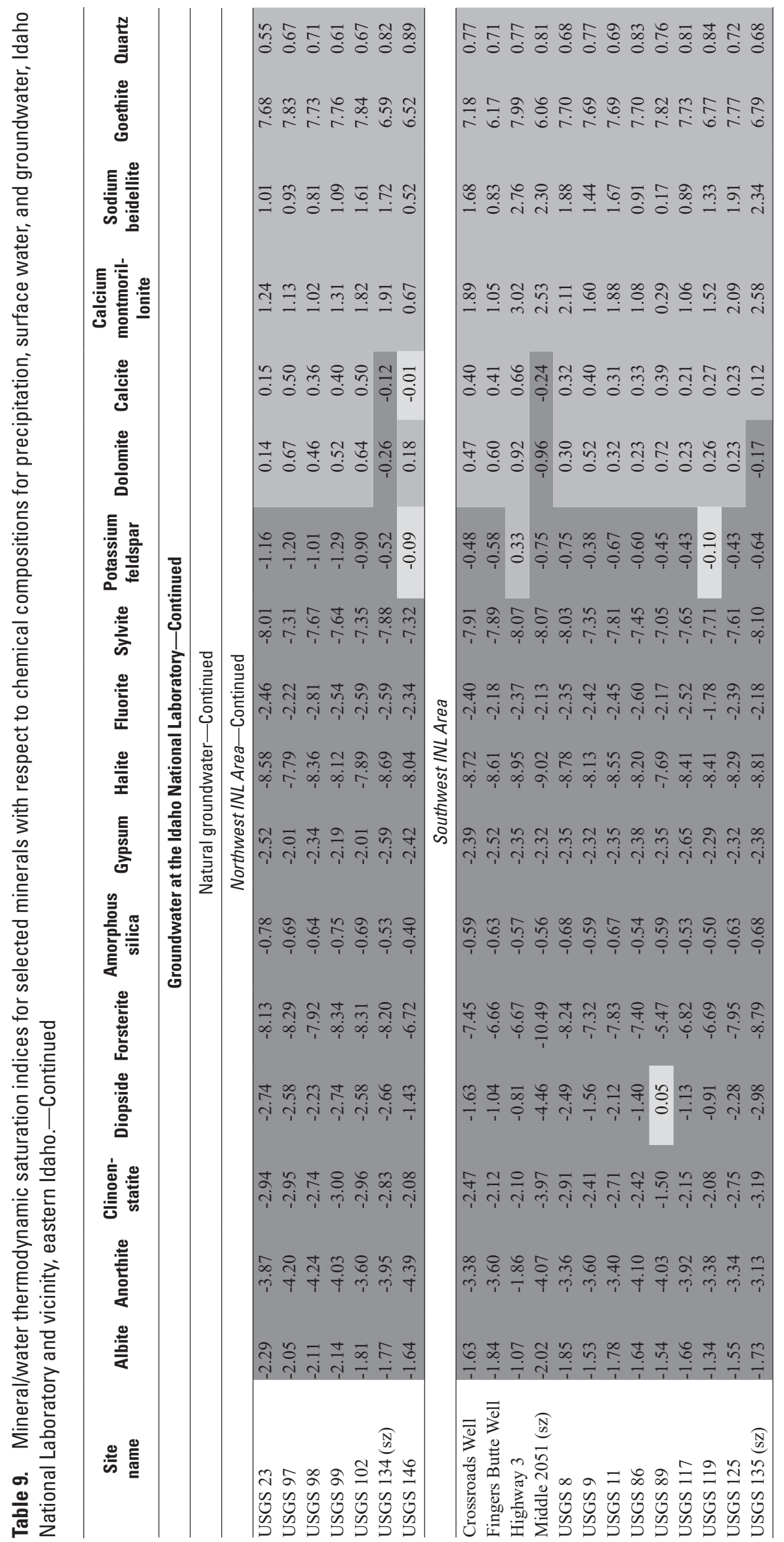




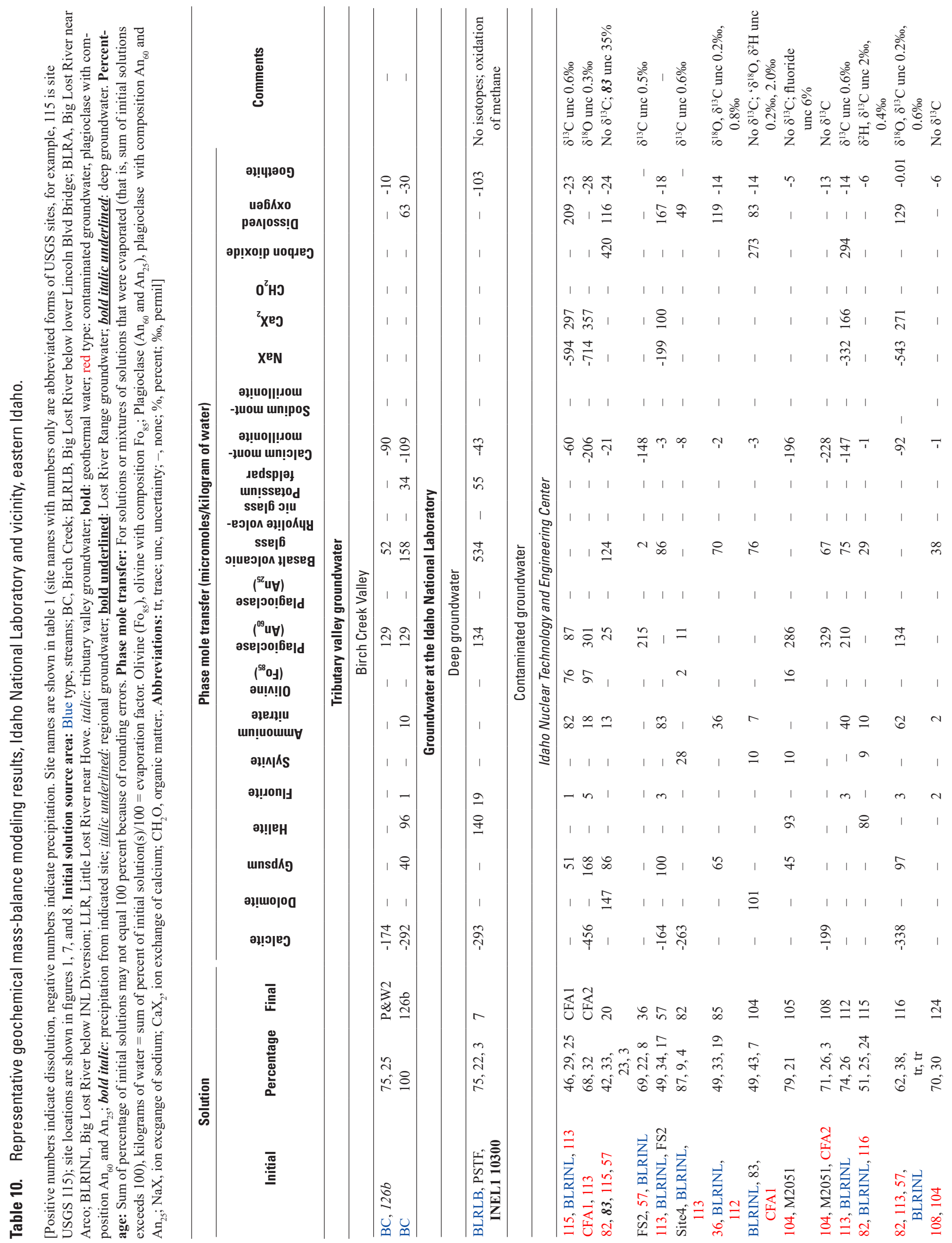




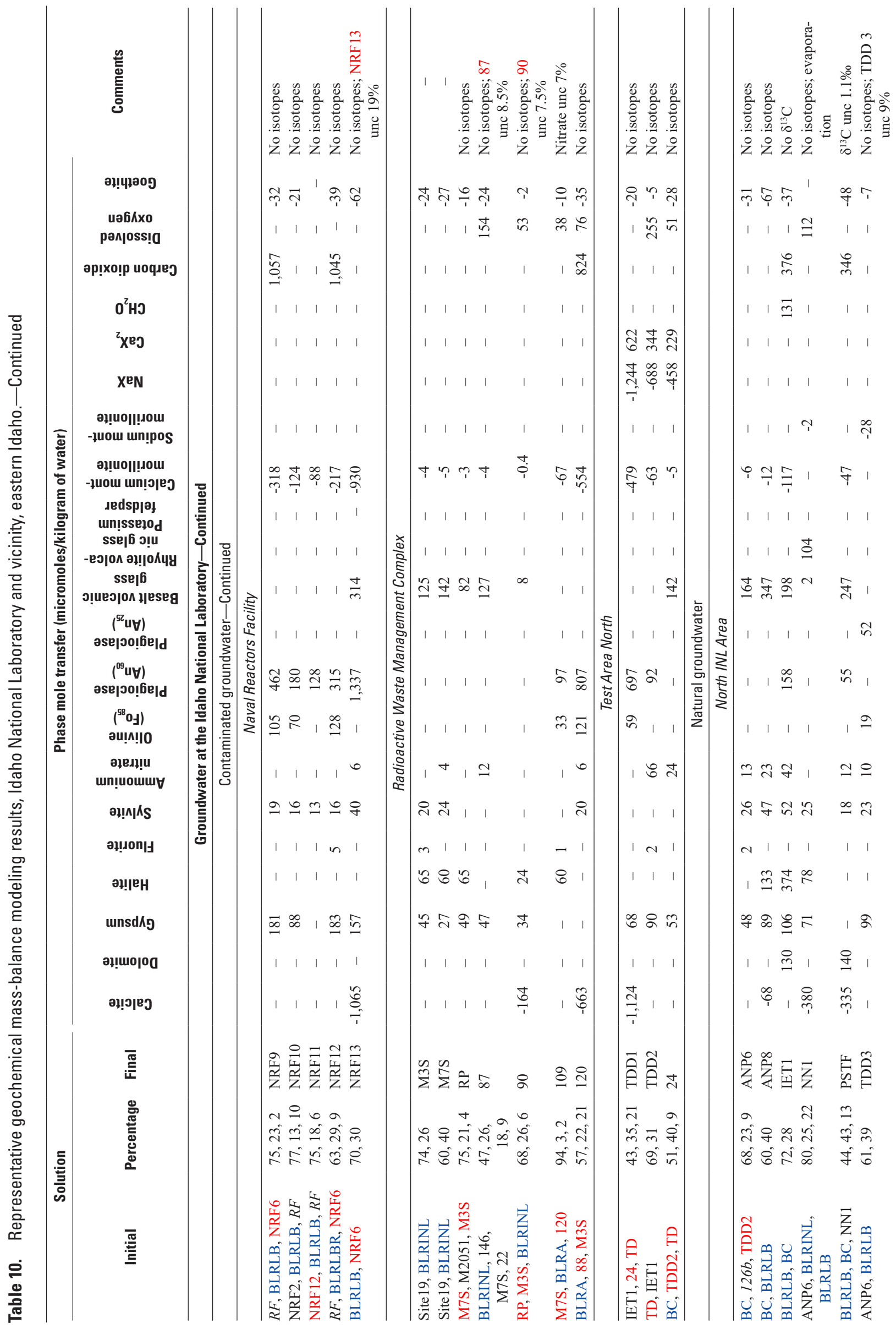




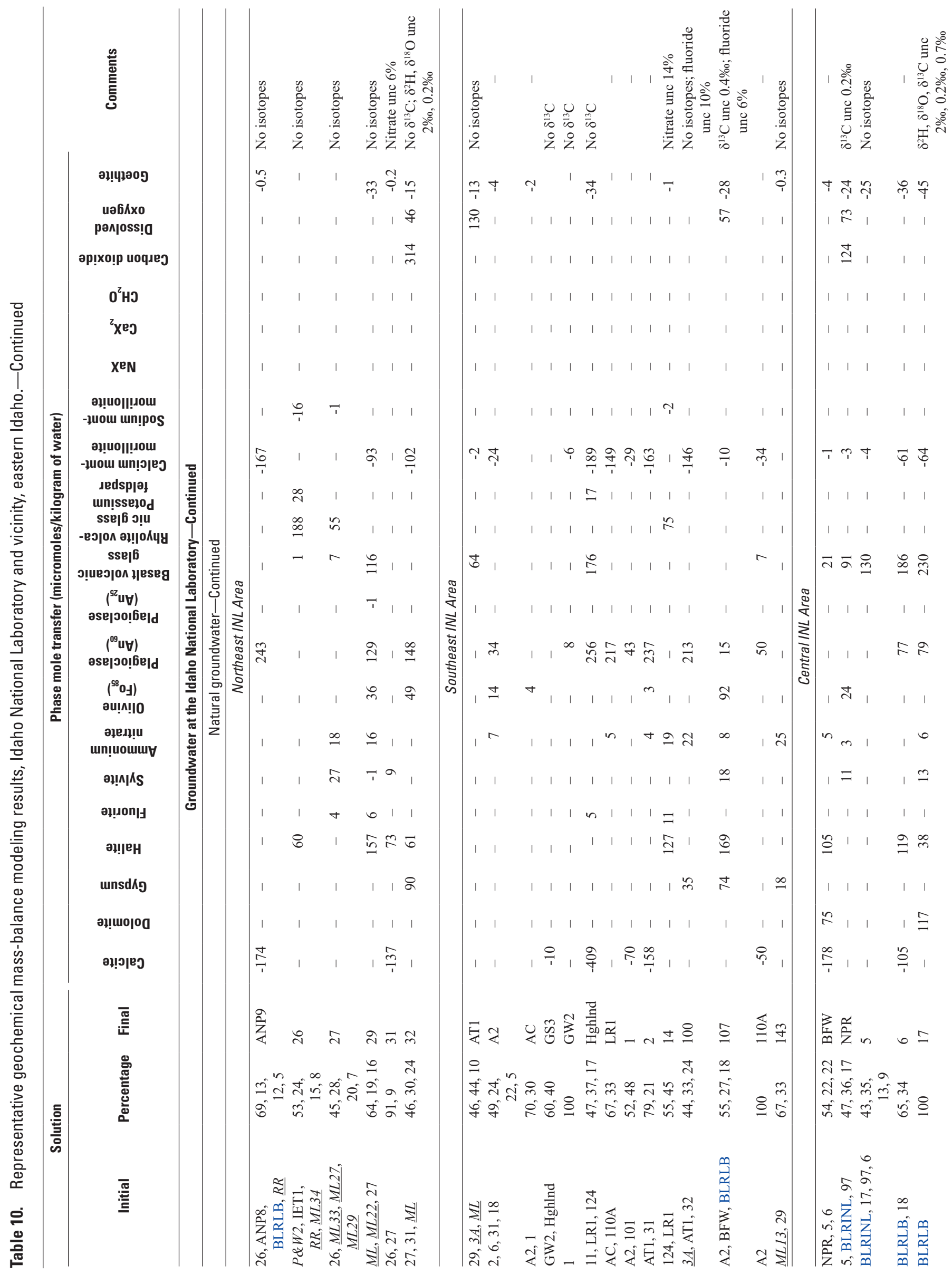




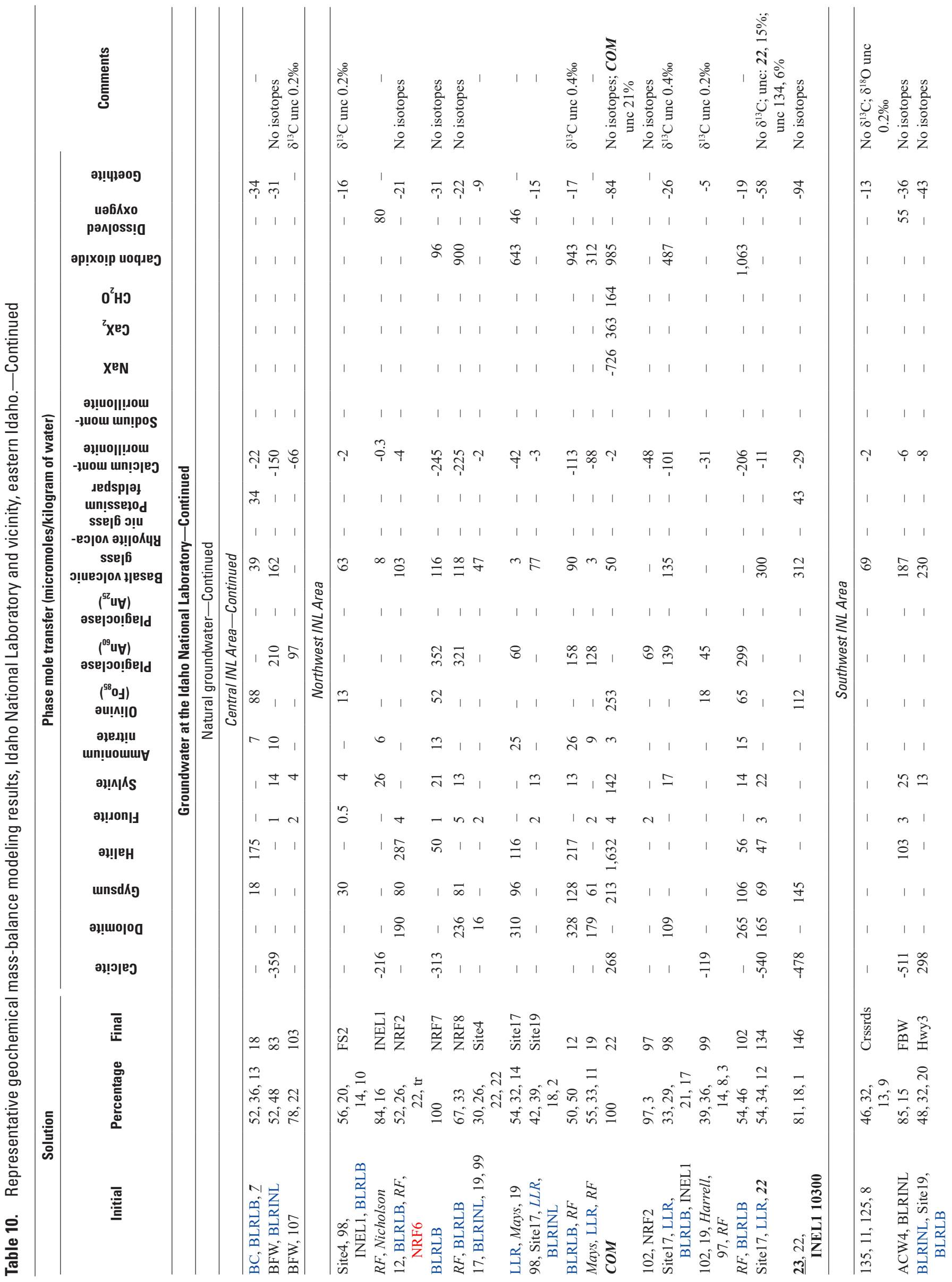




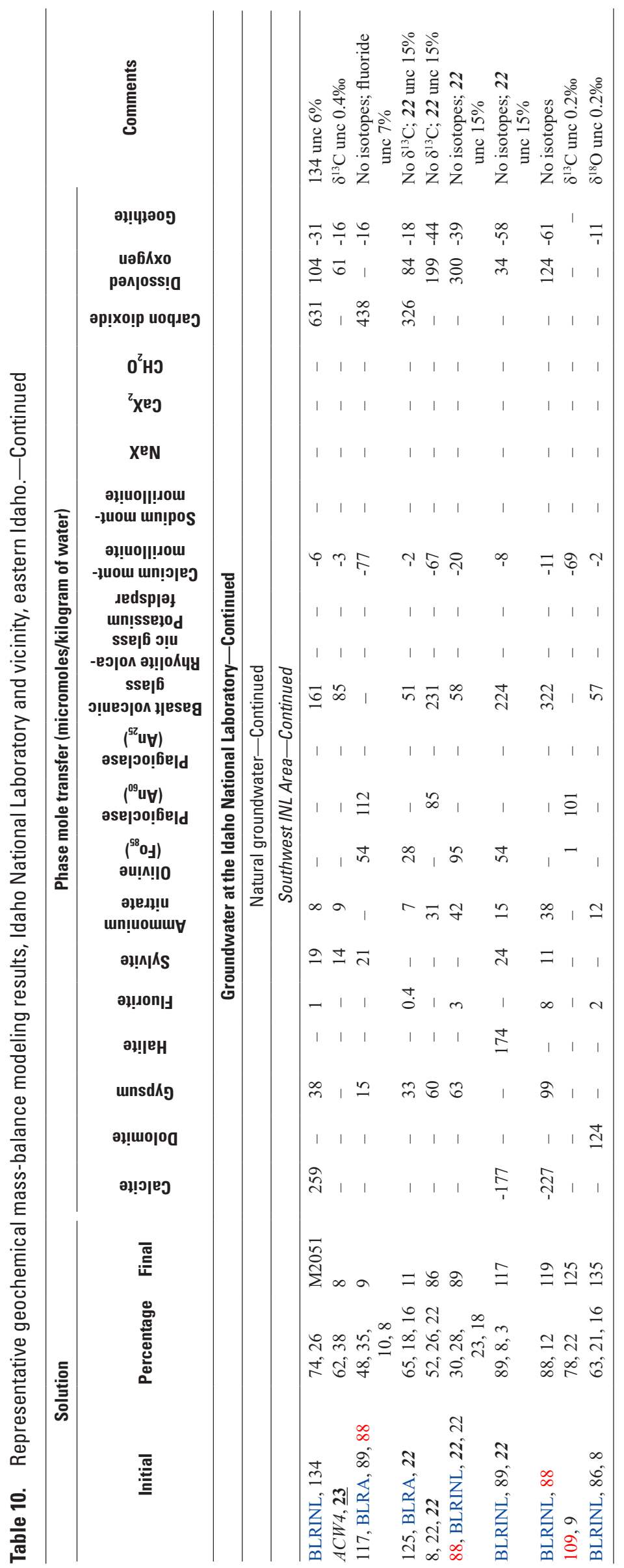


Table 11. Sources of recharge for groundwater based on geochemical modeling at and south of the Idaho National Laboratory, eastern Idaho.

[Site names are shown in table 1 (site names with numbers only are abbreviated forms of USGS sites, for example, 115 is site USGS 115); site locations are shown in figures 1, 7, and 8. Initial solution site: Blue type, streams; BC, Birch Creek; BLRLB, Big Lost River below lower Lincoln Blvd Bridge; BLRA, Big Lost River near Arco; BLRINL, Big Lost River below INL Diversion; LLR, Little Lost River near Howe. italic: tributary valley groundwater; bold: geothermal water; red type: contaminated groundwater; bold italic: precipitation from indicated site; italic underlined: regional groundwater; bold underlined: Lost River Range groundwater; bold italic underlined: deep groundwater. Percentages: Sum of percentage of initial solutions and sum of percentage of sources of recharge may not equal 100 percent because of rounding errors. Sources of recharge: For Big Lost River and Little Lost River valley groundwater: Recharge from the LLR and BC were included as recharge of groundwater from their respective valley. Geothermal water: Represented with borehole INEL-1 10,300 feet (referred to as initial solution 100 in Rattray [2015]). Percentage contribution from borehole INEL-1 10,300 feet is 5 percent at ML 27 and 3 percent at ML 29 and ML 34 (Rattray, 2015). Percentage contribution from geothermal water shown for values greater than or equal to 0.2 percent. Recharge of wastewater: Groundwater from TAN Disposal, NRF 6, USGS 113, and USGS 88 represented recharge of wastewater at Test Area North (TAN), Naval Reactors Facility (NRF), Idaho Nuclear Technology and Engineering Center (INTEC), and Radioactive Waste Management Complex (RWMC), respectively. Abbreviations: tr, trace; -, none]

\begin{tabular}{|c|c|c|c|c|c|c|c|c|c|c|c|}
\hline \multicolumn{3}{|c|}{ Solution } & \multicolumn{9}{|c|}{ Sources of recharge (percent) } \\
\hline Initial & Percentage & Final & $\begin{array}{l}\text { Precipi- } \\
\text { tation }\end{array}$ & $\begin{array}{c}\text { Big } \\
\text { Lost } \\
\text { River }\end{array}$ & $\begin{array}{l}\text { Lost River } \\
\text { Range } \\
\text { ground- } \\
\text { water }\end{array}$ & $\begin{array}{l}\text { Big Lost } \\
\text { River valley } \\
\text { ground- } \\
\text { water }\end{array}$ & $\begin{array}{l}\text { Little Lost } \\
\text { River valley } \\
\text { ground- } \\
\text { water }\end{array}$ & $\begin{array}{l}\text { Birch Creek } \\
\text { valley } \\
\text { ground- } \\
\text { water }\end{array}$ & $\begin{array}{c}\text { Regional } \\
\text { ground- } \\
\text { water }\end{array}$ & $\begin{array}{c}\text { Geo- } \\
\text { thermal } \\
\text { water }\end{array}$ & $\begin{array}{c}\text { Groundwater } \\
\text { containing } \\
\text { recharge of } \\
\text { wastewater }\end{array}$ \\
\hline \multicolumn{12}{|c|}{ Tributary valley groundwater } \\
\hline \multicolumn{12}{|c|}{ Birch Creek Valley } \\
\hline$B C, 126 b$ & 75,25 & P\&W2 & - & - & - & - & - & 100 & - & - & - \\
\hline$B C$ & 100 & $126 b$ & - & - & - & - & - & 100 & - & - & - \\
\hline \multicolumn{12}{|c|}{ Groundwater at the Idaho National Laboratory } \\
\hline \multicolumn{12}{|c|}{ Deep groundwater } \\
\hline $\begin{array}{l}\text { BLRLB, PSTF, } \\
\text { INEL1 } \mathbf{1 0 3 0 0}\end{array}$ & $75,22,3$ & 7 & - & 86 & - & - & - & 11 & - & 3 & - \\
\hline
\end{tabular}

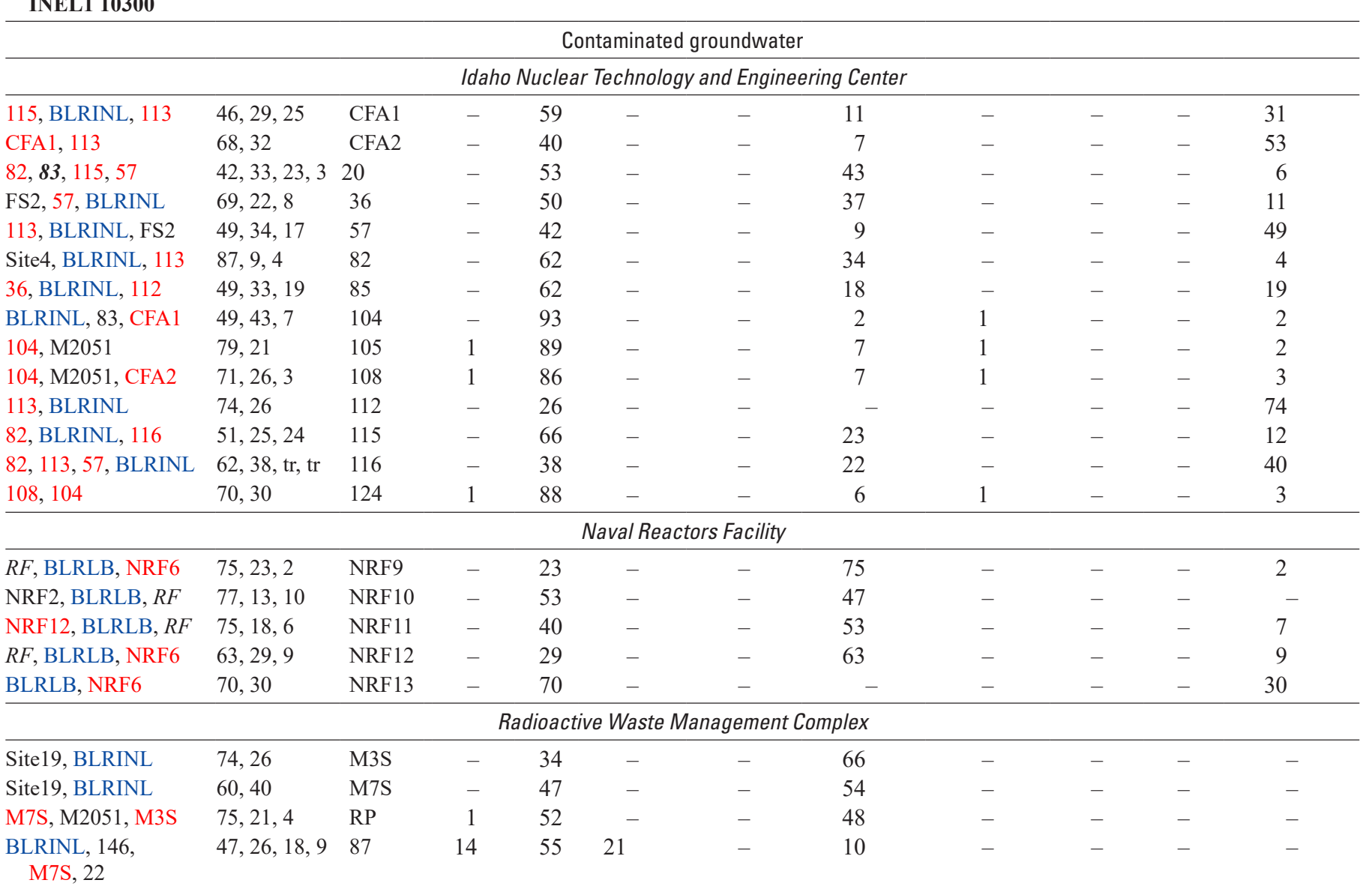


Table 11. Sources of recharge for groundwater based on geochemical modeling at and south of the Idaho National Laboratory, eastern Idaho.-Continued

\begin{tabular}{|c|c|c|c|c|c|c|c|c|c|c|c|}
\hline \multicolumn{3}{|c|}{ Solution } & \multicolumn{9}{|c|}{ Sources of recharge (percent) } \\
\hline Initial & Percentage & Final & $\begin{array}{l}\text { Precipi- } \\
\text { tation }\end{array}$ & $\begin{array}{l}\text { Big } \\
\text { Lost } \\
\text { River }\end{array}$ & $\begin{array}{l}\text { Lost River } \\
\text { Range } \\
\text { ground- } \\
\text { water }\end{array}$ & $\begin{array}{l}\text { Big Lost } \\
\text { River valley } \\
\text { ground- } \\
\text { water }\end{array}$ & $\begin{array}{l}\text { Little Lost } \\
\text { River valley } \\
\text { ground- } \\
\text { water }\end{array}$ & $\begin{array}{c}\text { Birch Creek } \\
\text { valley } \\
\text { ground- } \\
\text { water }\end{array}$ & $\begin{array}{c}\text { Regional } \\
\text { ground- } \\
\text { water }\end{array}$ & $\begin{array}{c}\text { Geo- } \\
\text { thermal } \\
\text { water }\end{array}$ & $\begin{array}{l}\text { Groundwater } \\
\text { containing } \\
\text { recharge of } \\
\text { wastewater }\end{array}$ \\
\hline \multicolumn{12}{|c|}{ Groundwater at the Idaho National Laboratory-Continued } \\
\hline \multicolumn{12}{|c|}{ Contaminated groundwater-Continued } \\
\hline RP, M3S, BLRINL & $68,26,6$ & 90 & 1 & 50 & - & - & 49 & - & - & - & - \\
\hline M7S, BLRA, 120 & $94,3,2$ & 109 & - & 48 & - & - & 51 & - & - & - & - \\
\hline BLRA, 88, M3S & $57,22,21$ & 120 & - & 64 & - & - & 13 & - & - & - & 22 \\
\hline \multicolumn{12}{|c|}{ Test Area North } \\
\hline IET1, 24, TD & $43,35,21$ & TDD1 & - & 34 & - & - & - & 31 & - & - & 34 \\
\hline \multicolumn{12}{|c|}{ North INL Area } \\
\hline$B C, 126 b$, TDD2 & $68,23,9$ & ANP6 & - & 2 & - & - & - & 92 & - & - & 6 \\
\hline$B C$, BLRLB & 60,40 & ANP8 & - & 40 & - & - & - & 60 & - & - & - \\
\hline BLRLB, $B C$ & 72,28 & IET1 & - & 72 & - & - & - & 28 & - & - & - \\
\hline $\begin{array}{l}\text { ANP6, BLRINL, } \\
\text { BLRLB }\end{array}$ & $80,25,22$ & ${ }^{1} \mathrm{NN} 1$ & - & 39 & - & - & - & 57 & - & - & 4 \\
\hline BLRLB, $B C$, NN1 & $44,43,13$ & PSTF & - & 49 & - & - & - & 51 & - & - & 1 \\
\hline ANP6, BLRLB & 61,39 & TDD3 & - & 40 & - & - & - & 56 & - & - & 4 \\
\hline \multicolumn{12}{|c|}{ Northeast INL Area } \\
\hline $\begin{array}{l}\text { 26, ANP8, } \\
\text { BLRLB, } R R\end{array}$ & $69,13,12,5$ & ANP9 & - & 29 & - & - & - & 49 & 21 & - & - \\
\hline \multicolumn{12}{|c|}{ Southeast INL Area } \\
\hline $29, \underline{3 A}, \underline{M L}$ & $46,44,10$ & AT1 & - & - & - & - & - & 2 & 97 & - & - \\
\hline $2,6,31,18$ & $49,24,22,5$ & $\mathrm{~A} 2$ & - & 27 & - & - & - & 26 & 46 & - & - \\
\hline $\mathrm{A} 2,1$ & 70,30 & $\mathrm{AC}$ & - & 23 & - & - & - & 22 & 54 & - & - \\
\hline GW2, Hghlnd & 60,40 & GS3 & 3 & 28 & - & - & 5 & 11 & 51 & - & - \\
\hline 1 & 100 & GW2 & - & 14 & - & - & - & 13 & 72 & - & - \\
\hline 11, LR1, 124 & $47,37,17$ & Hghlnd & 8 & 49 & - & - & 13 & 9 & 19 & - & 1 \\
\hline $\mathrm{AC}, 110 \mathrm{~A}$ & 67,33 & LR1 & - & 24 & - & - & - & 23 & 51 & - & - \\
\hline $\mathrm{A} 2,101$ & 52,48 & 1 & - & 14 & - & - & - & 13 & 72 & - & - \\
\hline AT1, 31 & 79,21 & 2 & - & 3 & - & - & - & 13 & 82 & - & - \\
\hline 124, LR1 & 55,45 & 14 & 1 & 59 & - & - & 4 & 11 & 23 & - & 2 \\
\hline$\underline{3 A}, \mathrm{AT} 1,32$ & $44,33,24$ & 100 & - & 2 & - & - & - & 8 & 91 & - & - \\
\hline A2, BFW, BLRLB & $55,27,18$ & 107 & - & 56 & - & - & 2 & 16 & 25 & - & - \\
\hline $\mathrm{A} 2$ & 100 & $110 \mathrm{~A}$ & - & 27 & - & - & - & 26 & 46 & - & - \\
\hline$\underline{M L 13}, 29$ & 67,33 & 143 & - & - & - & - & - & 1 & 98 & - & - \\
\hline \multicolumn{12}{|c|}{ Central INL Area } \\
\hline NPR, 5,6 & $54,22,22$ & BFW & - & 85 & - & - & 8 & 5 & - & - & - \\
\hline 5, BLRINL, 97 & $47,36,17$ & NPR & - & 87 & - & - & 12 & 1 & - & - & - \\
\hline BLRINL, 17, 97, 6 & $43,35,13,9$ & 5 & - & 91 & - & - & 7 & 2 & - & - & - \\
\hline BLRLB, 18 & 65,34 & 6 & - & 81 & - & - & - & 18 & - & - & - \\
\hline
\end{tabular}


Table 11. Sources of recharge for groundwater based on geochemical modeling at and south of the Idaho National Laboratory, eastern Idaho.-Continued

\begin{tabular}{|c|c|c|c|c|c|c|c|c|c|c|c|}
\hline \multicolumn{3}{|c|}{ Solution } & \multicolumn{9}{|c|}{ Sources of recharge (percent) } \\
\hline Initial & Percentage & Final & $\begin{array}{l}\text { Precipi- } \\
\text { tation }\end{array}$ & $\begin{array}{l}\text { Big } \\
\text { Lost } \\
\text { River }\end{array}$ & $\begin{array}{l}\text { Lost River } \\
\text { Range } \\
\text { ground- } \\
\text { water }\end{array}$ & $\begin{array}{l}\text { Big Lost } \\
\text { River valley } \\
\text { ground- } \\
\text { water }\end{array}$ & $\begin{array}{l}\text { Little Lost } \\
\text { River valley } \\
\text { ground- } \\
\text { water }\end{array}$ & $\begin{array}{c}\text { Birch Creek } \\
\text { valley } \\
\text { ground- } \\
\text { water }\end{array}$ & $\begin{array}{c}\text { Regional } \\
\text { ground- } \\
\text { water }\end{array}$ & $\begin{array}{c}\text { Geo- } \\
\text { thermal } \\
\text { water }\end{array}$ & $\begin{array}{c}\text { Groundwater } \\
\text { containing } \\
\text { recharge of } \\
\text { wastewater }\end{array}$ \\
\hline \multicolumn{12}{|c|}{ Groundwater at the Idaho National Laboratory—Continued } \\
\hline \multicolumn{12}{|c|}{ Natural groundwater-Continued } \\
\hline \multicolumn{12}{|c|}{ Central INL Area-Continued } \\
\hline BLRLB & 100 & 17 & - & 100 & - & - & - & - & - & - & - \\
\hline$B C, \mathrm{BLRLB}, \underline{7}$ & $52,36,13$ & 18 & - & 47 & - & - & - & 53 & - & 0.4 & - \\
\hline BFW, BLRINL & 52,48 & 83 & - & 92 & - & - & 4 & 3 & - & - & - \\
\hline BFW, 107 & 78,22 & 103 & - & 79 & - & - & 7 & 7 & 6 & - & - \\
\hline \multicolumn{12}{|c|}{ Northwest INL Area } \\
\hline $\begin{array}{l}\text { Site4, 98, INEL1, } \\
\text { BLRLB }\end{array}$ & $56,20,14,10$ & $\mathrm{FS} 2$ & - & 48 & - & - & 51 & - & - & - & - \\
\hline RF, Nicholson & 84,16 & INEL1 & - & - & - & - & 100 & - & - & - & - \\
\hline $\begin{array}{l}\text { 12, BLRLB, } R F \text {, } \\
\text { NRF6 }\end{array}$ & $52,26,22, \operatorname{tr}$ & NRF2 & - & 52 & - & - & 48 & - & - & - & - \\
\hline BLRLB & 100 & NRF7 & - & 100 & - & - & - & - & - & - & - \\
\hline$R F$, BLRLB & 67,33 & NRF8 & - & 33 & - & - & 67 & - & - & - & - \\
\hline 17, BLRINL, 19, 99 & $30,26,22,22$ & Site4 & - & 61 & - & - & 39 & - & - & - & - \\
\hline LLR, Mays, 19 & $54,32,14$ & Site17 & - & - & - & - & 100 & - & - & - & - \\
\hline $\begin{array}{l}\text { 98, Site17, LLR, } \\
\text { BLRINL }\end{array}$ & $42,39,18,2$ & Site19 & - & 11 & - & - & 90 & - & - & - & - \\
\hline BLRLB, $R F$ & 50,50 & 12 & - & 50 & - & - & 50 & - & - & - & - \\
\hline Mays, $L L R, R F$ & $55,33,11$ & 19 & - & - & - & - & 99 & - & - & - & - \\
\hline COM & 100 & 22 & 100 & - & - & - & - & - & - & - & - \\
\hline $102, \mathrm{NRF} 2$ & 97,3 & 97 & - & 46 & - & - & 54 & - & - & - & - \\
\hline $\begin{array}{l}\text { Site17, LLR, } \\
\text { BLRLB, INEL1 }\end{array}$ & $33,29,21,17$ & 98 & - & 21 & - & - & 79 & - & - & - & - \\
\hline $\begin{array}{l}\text { 102, 19, Harrell, } \\
\quad 97, R F\end{array}$ & $\begin{array}{l}39,36,14 \\
\quad 8,3\end{array}$ & 99 & - & 22 & - & - & 78 & - & - & - & - \\
\hline$R F$, BLRLB & 54,46 & 102 & - & 46 & - & - & 54 & - & - & - & - \\
\hline Site17, LLR, 22 & $54,34,12$ & 134 & 12 & - & - & - & 88 & - & - & - & - \\
\hline$\underline{\underline{23}}, 22$, INEL1 10300 & $81,18,1$ & 146 & 18 & - & 81 & - & - & - & - & 1 & - \\
\hline \multicolumn{12}{|c|}{ Southwest INL Area } \\
\hline $135,11,125,8$ & $46,32,13,9$ & Crssrds & 10 & 53 & 8 & 13 & 13 & - & - & - & 1 \\
\hline$A C W 4, \mathrm{BLRINL}$ & 85,15 & FBW & - & 15 & - & 85 & - & - & - & - & - \\
\hline $\begin{array}{l}\text { BLRINL, Site19, } \\
\text { BLRLB }\end{array}$ & $48,32,20$ & Hwy3 & - & 72 & - & - & 29 & - & - & - & - \\
\hline BLRINL, 134 & 74,26 & M2051 & 3 & 74 & - & - & 23 & - & - & - & - \\
\hline$A C W 4, \underline{\mathbf{2 3}}$ & 62,38 & 8 & - & - & 38 & 62 & - & - & - & - & - \\
\hline 117, BLRA, 89, 88 & $48,35,10,8$ & 9 & 7 & 81 & - & - & - & - & - & - & 12 \\
\hline 125, BLRA, 22 & $65,18,16$ & 11 & 17 & 54 & - & - & 26 & - & - & - & 2 \\
\hline $8,22,22$ & $52,26,22$ & 86 & 48 & - & 20 & 32 & - & - & - & - & - \\
\hline 88, BLRINL, 22, 22 & $30,28,23,18$ & 89 & 41 & 28 & - & - & - & - & - & - & 30 \\
\hline BLRINL, 89, 22 & $89,8,3$ & 117 & 6 & 91 & - & - & - & - & - & - & 2 \\
\hline BLRINL, 88 & 88,12 & 119 & - & 88 & - & - & - & - & - & - & 12 \\
\hline 109,9 & 78,22 & 125 & 2 & 55 & - & - & 39 & - & - & - & 3 \\
\hline BLRINL, 86, 8 & $63,21,16$ & 135 & 10 & 63 & 10 & 17 & - & - & - & - & - \\
\hline
\end{tabular}

${ }^{1}$ Percentages normalized by a factor of 1.27 to adjust for evaporation (see headnote to table 7 ). 


\section{Glossary}

Contaminated groundwater at the Idaho National Laboratory is groundwater influenced by discharge of wastewater. Contaminated groundwater was identified from various chemical signatures. These included groundwater samples with (1) large tritium activities ( $>75 \mathrm{pCi} / \mathrm{L})$, (2) large sodium and sulfate concentrations ( $>25$ and $>40 \mathrm{mg} / \mathrm{L}$, respectively), (3) large specific conductance values $\left(>600 \mu \mathrm{S} / \mathrm{cm}\right.$ at $\left.25^{\circ} \mathrm{C}\right)$, and, (4) in the area near the Naval Reactors Facility, large chloride/nitrate ratios $(>75)$.

Deep groundwater at the Idaho National Laboratory is groundwater that is more than the 250 feet below the water table (does not include geothermal water).

Geothermal water is groundwater in the study area with water temperatures exceeding $25^{\circ} \mathrm{C}$.

Natural groundwater at and south of the Idaho National Laboratory, excluding contaminated groundwater, is groundwater that is less than the 250 feet below the water table.

Regional groundwater is groundwater in the eastern Snake River Plain aquifer east of the Idaho National Laboratory (INL). Regional groundwater also includes groundwater from wells ML 22, USGS 3A, and USGS 101 in the southeastern part of the INL.

Tributary valley groundwater is groundwater from the Big Lost River, Little Lost River, and Birch Creek valleys. 


\section{Appendix 1. Equations}

\section{Delta Notation}

The stable isotope ratios of hydrogen $\left({ }^{2} \mathrm{H} /{ }^{1} \mathrm{H}\right)$, oxygen $\left({ }^{18} \mathrm{O} /{ }^{16} \mathrm{O}\right)$, and carbon $\left({ }^{13} \mathrm{C} /{ }^{12} \mathrm{C}\right)$ were reported as permil using delta notation $(\delta)$, which is the ratio of the abundance of the minor isotope to the predominant isotope for an element in a sample relative to the same isotopes in a reference material. For example, for the oxygen stable isotope ratio, this would be the abundance of ${ }^{18} \mathrm{O}$ (the minor isotope) to ${ }^{16} \mathrm{O}$ (the predominant isotope) relative to the same isotopes in a reference material:

$$
\delta{ }^{18} \mathrm{O}_{\text {sample }}=\frac{\left({ }^{18} \mathrm{O} /{ }^{16} \mathrm{O}\right)_{\text {sample }}-\left({ }^{18} \mathrm{O} /{ }^{16} \mathrm{O}\right)_{\text {reference }}}{\left({ }^{18} \mathrm{O} /{ }^{16} \mathrm{O}\right)_{\text {reference }}} \times M,
$$

where

$\left({ }^{18} \mathrm{O} /{ }^{16} \mathrm{O}\right)_{\text {sample }} \quad$ is the isotope ratio of oxygen-18 and oxygen-16 of the sample,

$\left({ }^{18} \mathrm{O} /{ }^{16} \mathrm{O}\right)_{\text {reference }}$ is the isotope ratio of oxygen-18 and oxygen-16 of the reference material, and

$M \quad$ is a multiplication factor of 1,000 to express reported $\delta$-values as parts per thousand (permil).

Delta notations are $\delta^{2} \mathrm{H}$ and $\delta^{13} \mathrm{C}$ for the stable isotope ratios of hydrogen and carbon, respectively.

\section{Saturation Indices}

Saturation indices (SI) were calculated as:

$$
\mathrm{SI}=\log \left(\frac{I A P}{K}\right)
$$

where

$$
\begin{gathered}
\text { IAP is the ion activity product of a chemical } \\
\text { reaction and } \\
K \quad \begin{array}{c}
\text { is the equilibrium constant for the chemical } \\
\text { reaction. }
\end{array}
\end{gathered}
$$

See Nordstrom and Munoz (1986) for discussion of ion activity product and equilibrium constant.

\section{Charge Balance}

Charge balance was calculated as:

where

$$
C B=\frac{\sum_{1}^{i} C_{i}-\sum_{1}^{j} C_{j}}{\sum_{1}^{i} C_{i}+\sum_{1}^{j} C_{j}} \times 100
$$

$C B$ is the charge balance for a water sample (in units of percent);

$C_{i} \quad$ is concentration (in equivalent units) of a cation;

$C_{j} \quad$ is concentration (in equivalent units) of a cation; and

$i$ and $j \quad$ are the number of measured cation and anion species, respectively, in the water sample.

\section{Mass Action Equation for Monovalent-Divalent Cation Exchange}

The mass action equation for the monovalent-divalent cation exchange reaction shown in table 2 is (modified from Drever, 1997, p. 84):

$$
\frac{\alpha_{\mathrm{Ca}-\mathrm{Ex}}}{\alpha_{\mathrm{Na}-\mathrm{Ex}}^{2}}=K_{\mathrm{Na}-\mathrm{Ca}} \frac{\alpha_{\mathrm{Ca}^{2+}}}{\alpha_{\mathrm{Na}^{+}}^{2}},
$$

where

$\alpha_{\text {Ca-Ex }}$ is the activity of $\mathrm{Ca}$ on the exchange sites,

$\alpha_{\mathrm{Na}-\mathrm{Ex}}$ is the activity of $\mathrm{Na}$ on the exchange sites,

$K_{\mathrm{Na}-\mathrm{Ca}} \quad$ is the equilibrium constant for $\mathrm{Na}-\mathrm{Ca}$ exchange,

$\alpha_{\mathrm{Ca}}{ }^{2+}$ is the activity of $\mathrm{Ca}^{2+}$ in the solution, and

$\alpha_{\mathrm{Na}}{ }^{+}$is the activity of $\mathrm{Na}^{+}$in the solution.

\section{Calculation of Uncertainty}

The percentage of wastewater in groundwater at USGS 113 was calculated by solving for $\mathrm{x}$ in the following equation:

$$
\mathrm{Cl} l_{(113)}=\left[\mathrm{Cl}_{(\mathrm{INTEC})}\right](x)+\left[\mathrm{Cl} l_{(\mathrm{bckgrnd})}\right](1-x)
$$

where

$\mathrm{Cl}_{(113)}$ is the chloride concentration in groundwater from USGS 113 (218 mg/L, table 7),

$C l_{\text {(INTEC) }}$ is the chloride concentration in wastewater discharged from INTEC $(267 \pm 16 \mathrm{mg} / \mathrm{L}$, table 3),

$\mathrm{Cl}_{\text {(bckgrnd) }}$ is the background chloride concentration in groundwater upgradient of INTEC, and

$x \quad$ is the fraction of wastewater in groundwater at USGS 113. 
Chloride concentrations in natural groundwater upgradient of the INTEC ranged from 10 to $20 \mathrm{mg} / \mathrm{L}$ (Rattray, 2018; fig. 28M), and the background chloride concentration was estimated to be $15 \pm 5 \mathrm{mg} / \mathrm{L}$ (Rattray, 2018, fig. 28M). Using this background chloride concentration, wastewater comprised 81 percent of groundwater at USGS 113. Using the same equation for NRF 6 , and a background chloride concentration of $36 \pm 4$ $\mathrm{mg} / \mathrm{L}$ (based on 30 chloride concentrations in groundwater collected from USGS 12 between 1990 and 1996; Rattray, 2018, fig. 19M), wastewater comprised 121 percent of groundwater at NRF 6 (a percentage exceeding 100 percent probably reflects the variability in the concentration of chloride discharged in wastewater at NRF; table 3).

The combined uncertainty in the fraction of wastewater discharged at INTEC in contaminated groundwater at USGS 113 was calculated as:

$$
\begin{aligned}
\text { Uncertainty } & =U_{C l \_113}+\left(U_{C l_{-} I N T E C}\right)(x) \\
& +\left(U_{C l \_b c k g r n d}\right)(1-x),
\end{aligned}
$$

where

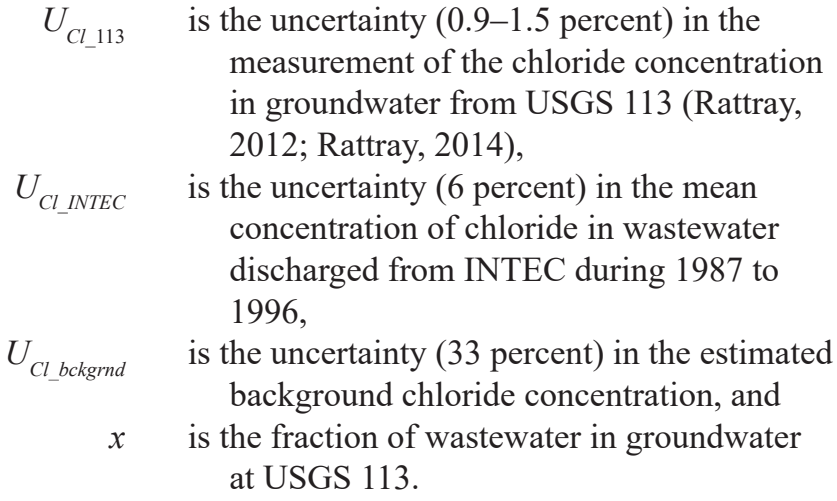

The combined uncertainty in the fraction of wastewater discharged at INTEC in contaminated groundwater at USGS 113 ranged from 12.0 to 12.6 percent. Using equation $1-6$, and taking the absolute value of $\left(U_{C l \text { bckgrnd }}\right)(1-x)$, the combined uncertainty in the fraction of wastewater discharged at NRF in contaminated groundwater at NRF 6 ranged from 36.8 to 37.4 percent.

\section{References Cited}

Drever, J.I., 1997, The geochemistry of natural waters: Upper Saddle River, New Jersey, Prentice Hall, 436 p.

Nordstrom, D.K., and Munoz, J.L., 1986, Geochemical thermodynamics: Palo Alto, California, Blackwell Scientific Publications, $477 \mathrm{p}$.

Rattray, G.W., 2012, Evaluation of quality-control data collected by the U.S. Geological Survey for routine water-quality activities at the Idaho National Laboratory, southeastern Idaho, 1996-2001: U.S. Geological Survey Scientific Investigations Report 2012-5270 (DOE/ ID-22222), 74 p., http://pubs.usgs.gov/sir/2012/5270/.

Rattray, G.W., 2014, Evaluation of quality-control data collected by the U.S. Geological Survey for routine water-quality activities at the Idaho National Laboratory, southeastern Idaho, 2002-2008: U.S. Geological Survey Scientific Investigations Report 2014-5027 (DOE/ ID-22228), 65 p., http://pubs.usgs.gov/sir/2014/5027/.

Rattray, G.W., 2018, Geochemistry of groundwater in the eastern Snake River Plain aquifer, Idaho National Laboratory, eastern Idaho: U.S. Geological Survey Professional Paper 1837-A (DOE/ID-22246), 198 p. [Also available at https://doi.org/10.3133/pp1837A.] 


\section{Appendix 2. Recharge at NRF 7}

Water-quality samples have been routinely collected at NRF 7 since 1991 (U.S. Geological Survey, 2018). Collection of low-level tritium data began in 1997, and most of the tritium activities since 1997 were less than $5 \mathrm{pCi} / \mathrm{L}(1 \sigma$ uncertainties ranged from 0.15 to $3.75 \mathrm{pCi} / \mathrm{L})$, indicating that most groundwater at NRF 7 was from recharge that probably occurred before 1950 (Rattray, 2018). Periodically, however, larger tritium activities [8.7-56.7 pCi/L ( $1 \sigma$ uncertainties of about \pm 10 percent] were measured from groundwater collected from NRF 7, and these larger tritium activities coincided with large pulses of discharge from the BLR (fig. 2-1) ${ }^{26}$ The tritium activities subsequently decreased as discharge decreased. The large, positive correlation coefficient $(\mathrm{r}=0.82, \mathrm{n}=24)$ between monthly discharge in the BLR and tritium activity in groundwater collected from NRF 7 supports an interpretation that the large tritium activities represent very recent recharge from the BLR. The best correlation was achieved by matching

\footnotetext{
${ }^{26}$ Discharge and tritium data in fig. 2-1 were from 1997 to 2004 . These dates represent the beginning of low-level tritium measurements in 1997 and the end of the period when three or four measurements of tritium were made annually. Four censored tritium measurements (that is, activities preceded by a " <" symbol) were plotted using the censored value and two tritium measurements reported as $<$ mda (minimum detectable activity) and $-2.30 \mathrm{pCi} / \mathrm{L}$ were plotted as $0.0 \mathrm{pCi} / \mathrm{L}$.
}

tritium activities with monthly discharge values for the previous month (that is, June tritium activity was correlated with May discharge). This indicated that infiltrating BLR water takes about 1 month to travel to NRF 7, and that as discharge decreases the corresponding decrease in tritium activity in groundwater at NRF 7 lags the decrease in discharge by about 1 month.

Collection of water-quality samples at NRF 7 requires a reduction in pumping volume to 2.5 gallons per minute to avoid pumping the borehole dry (Bartholomay and others, 2014). Consequently, the basalt aquifer at NRF 7 appears to be a tight formation. The young groundwater collected at NRF 7 during large discharge periods, therefore, probably was flowing into the top of the well from the unsaturated zone. The small tritium activities in groundwater collected from NRF 7 shortly after the end of large discharge periods show that young groundwater is a transient feature at this well and that young groundwater does not have a sustained residence time in the aquifer at NRF 7.

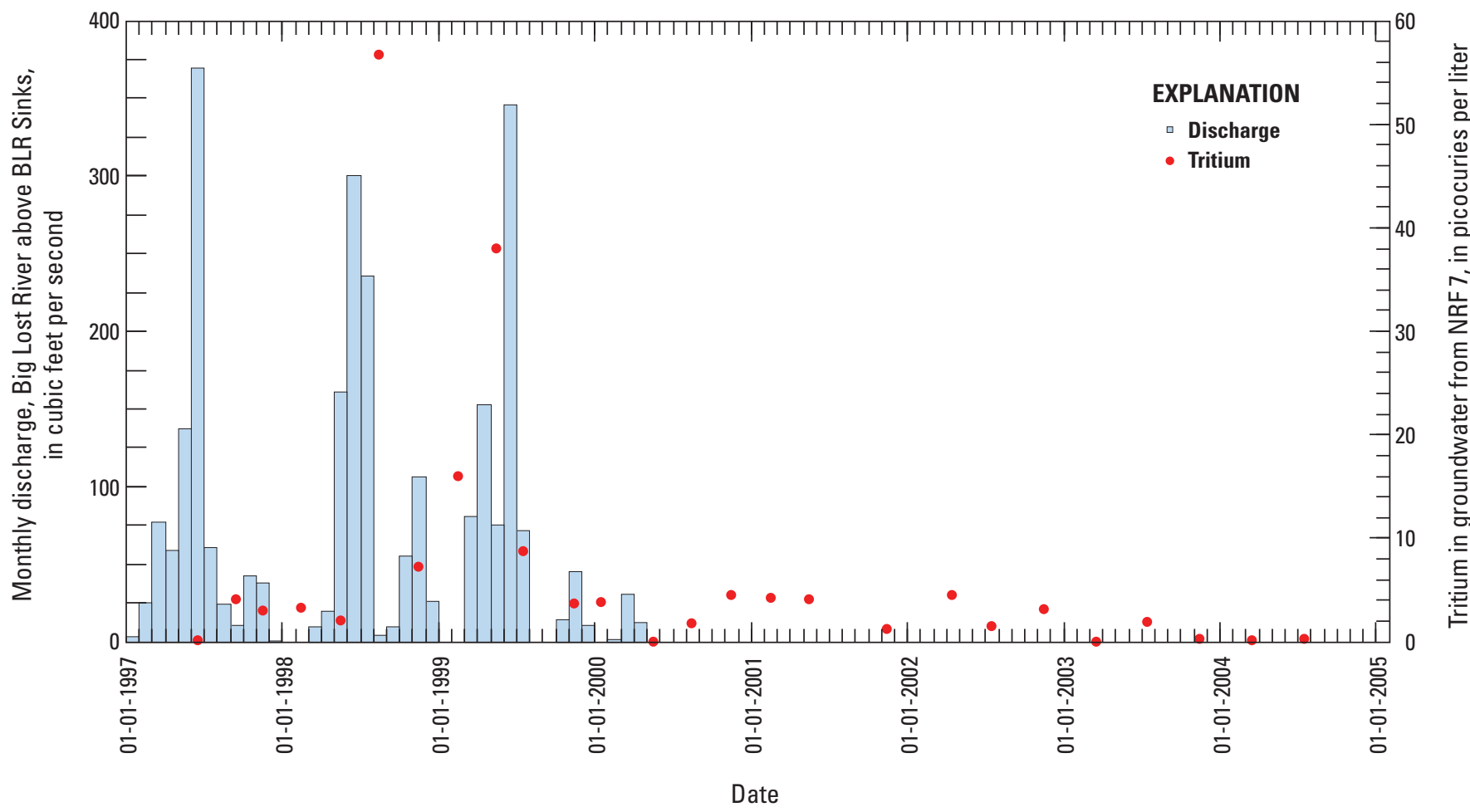

Figure 2-1. Monthly discharge at Big Lost River (BLR) above BLR Sinks near Howe, Idaho, and tritium activity in groundwater collected from NRF 7, Idaho National Laboratory, eastern Idaho. 


\section{References Cited}

Bartholomay, R.C., Maimer, N.V., and Wehnke, A.J., 2014, Field methods and quality-assurance plan for water-quality activities and water-level measurements, U.S. Geological Survey, Idaho National Laboratory, Idaho: U.S. Geological Survey Open-File Report 2014-1146 (DOE/ID-22230), 66 p.

Rattray, 2018, Geochemistry of groundwater in the Eastern Snake River Plain aquifer, Idaho National Laboratory, eastern Idaho: U.S. Geological Survey Professional Paper 1837-A (DOE/ID-22246), 198 p. [Also available at https:// doi.org/10.3133/pp1837A.]

U.S. Geological Survey, 2018, National Water Information System database: U.S. Geological Survey, accessed April 17, 2018, at http://waterdata.usgs.gov/nwis. 
Publishing support provided by the U.S. Geological Survey Science Publishing Network, Tacoma Publishing Service Center

For more information concerning the research in this report, contact the Director, Idaho Water Science Center U.S. Geological Survey 230 Collins Road Boise, Idaho 83702 http://id.water.usgs.gov 


\section{寍}

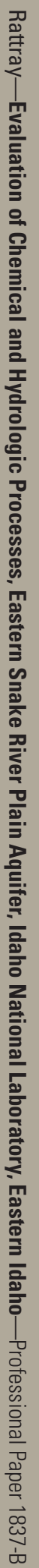

